\title{
WestVirginiaUniversity
}

THE RESEARCH REPOSITORY @ WVU

Graduate Theses, Dissertations, and Problem Reports

2008

\section{Development of an optimized short-span steel bridge design package}

Gabor I. Nagy

West Virginia University

Follow this and additional works at: https://researchrepository.wvu.edu/etd

\section{Recommended Citation}

Nagy, Gabor I., "Development of an optimized short-span steel bridge design package" (2008). Graduate Theses, Dissertations, and Problem Reports. 1982.

https://researchrepository.wvu.edu/etd/1982

This Thesis is protected by copyright and/or related rights. It has been brought to you by the The Research Repository @ WVU with permission from the rights-holder(s). You are free to use this Thesis in any way that is permitted by the copyright and related rights legislation that applies to your use. For other uses you must obtain permission from the rights-holder(s) directly, unless additional rights are indicated by a Creative Commons license in the record and/ or on the work itself. This Thesis has been accepted for inclusion in WVU Graduate Theses, Dissertations, and Problem Reports collection by an authorized administrator of The Research Repository @ WVU. For more information, please contact researchrepository@mail.wvu.edu. 
Development of an optimized Short-Span Steel Bridge Design Package

\author{
Gabor I. Nagy
}

Thesis submitted to the

College of engineering and mineral Resources

at West Virginia University

in partial fulfillment of the requirements

for the degree of

Master of Science

In

Civil Engineering

Karl E. Barth, Ph.D., Chair

David Martinelli, Ph.D.

Udaya B. Halabe, Ph.D.

Department of Civil and Environmental Engineering

Morgantown, West Virginia

2008

Keywords: bridge design, steel bridge, LRFD, parametric studies, plate girders 


\section{Abstract \\ Development of an Optimized Short-span Steel Bridge Package \\ Gabor I. Nagy}

West Virginia Department of Transportation indicates that a significant number of bridges in West Virginia are structurally deficient or functionally obsolete. One third of the nation's bridges have similar conditions due to the age of the infrastructure and ever increasing traffic demands. The resources available to replace or rehabilitate those structures are finite, hence cost effective means of replacing the inadequate structures is necessary. One of the solutions intended to ease the increasing demands of replacing those structures are standardized bridge plans by providing a cost effective method to save time and resources. Therefore, the focus of this effort is the development of an optimized short-span steel bridge package.

The study focused on developing optimized plans for two roadway sections for spans ranging from 40 feet to 140 feet in 5 feet increments. The girders designed in this effort were optimized based on weight and targeted various cross section depth to span length ratios incorporating homogeneous, hybrid and rolled sections.

This effort also focused on the feasibility of incorporating limited plate sizes in the design of steel girders. Designs from the optimized study and the limited plate size study were compared and evaluated to offer cost and time savings. 


\section{Acknowledgements}

I would like to thank Dr. Karl Barth for the opportunity to pursue my Master's Degree at West Virginia University under his guidance and direction. His advising, teaching and human qualities are simply the standard by which great education should be measured. The engineering knowledge and practical education I received during my graduate education is invaluable.

In addition, I appreciate the guidance and contribution of Dr. David Martinelli, who made it available to pursue my graduate degree under Dr. Barth and Dr. Udaya B. Halabe, for serving on my graduate committee. I would also like to acknowledge and thank Lora B. Freeman for her help to better understand the scope of my thesis. Her thesis is an excellent work and served as a guidance to complete mine.

I would like to express thanks to the West Virginia Division of Highways for funding my research.

Finally, I would like to thank my family in Hungary, Dr. Paul E. Edwards and his wife, Peggy Edwards for their unbelievable support and guidance. Their encouragement is inspiring. 


\section{Table of Contents}

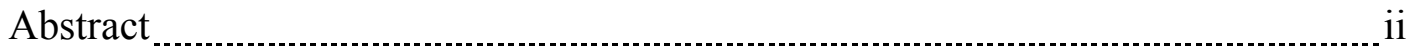

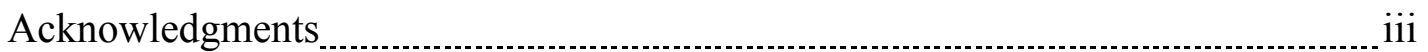

Table of Contents

List of Tables $\ldots$

List of Figures

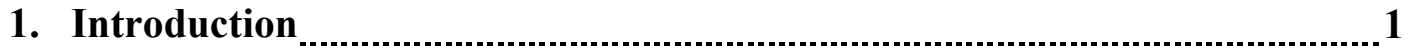

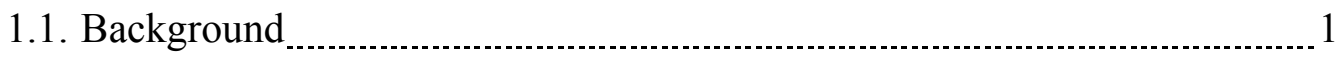

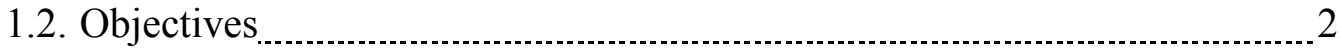

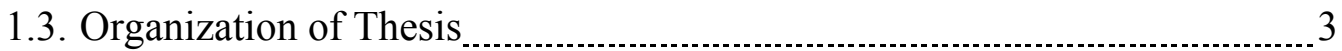

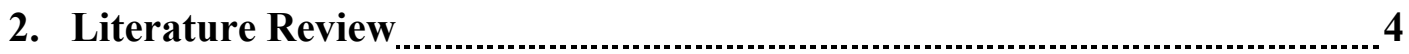

2.1. Background

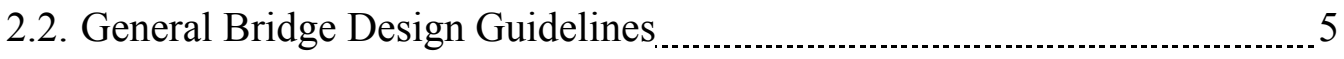

2.3. Summary of Standardized Bridge Plans _.......................................... 12

2.4. Innovative ideas for Rapid Construction $\ldots \ldots \ldots \ldots$

2.5. Summary

\section{Fundamental Steel Bridge Design Aspects of the AASHTO LRFD Bridge}

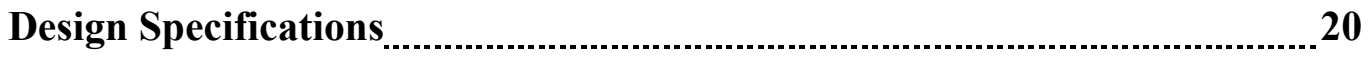

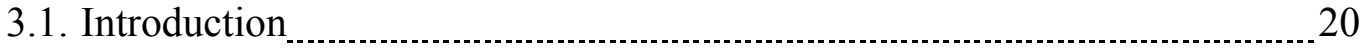

3.2. Design Loads

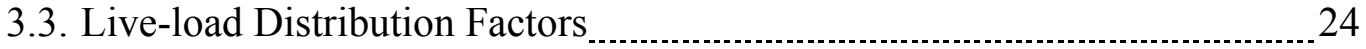

3.4. Other Force Effects 
3.6. Summary of the Third Edition of the AASHTO LRFD Specifications _....... 35

3.7. Limit State specifications

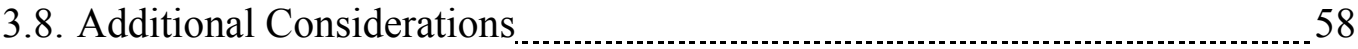

4. Optimized Short-Span Steel Bridge Girder Design Study .........................62

4.1. Introduction $\ldots 2$

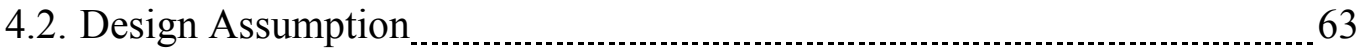

4.3. Design Approach

4.4. Design Summary and Observations

5. Short-Span Limited Plate Size Design Study ...........................................

5.1. Introduction

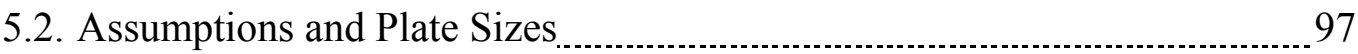

5.3. Designs and Results

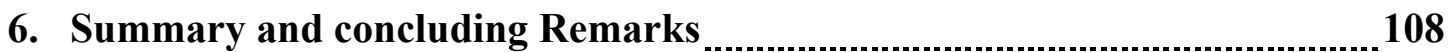

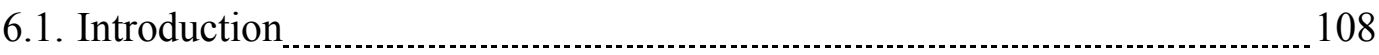

6.2. Scope of Work

6.3. Summary of Results

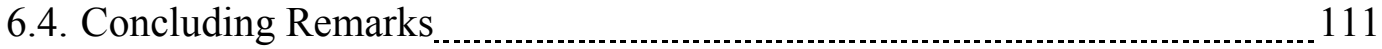

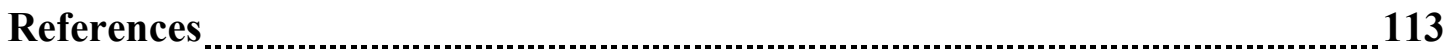

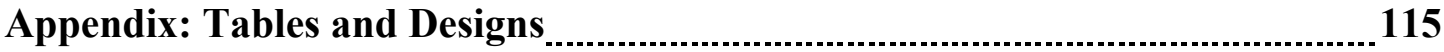




\section{List of Tables}

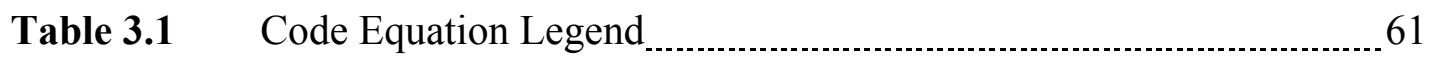

Table 3.2 Multiple Presence Factors …………................................................ 62

Table 3.3 Dynamic Load Allowance, IM

Table 3.4 Load Modifiers $\ldots \ldots$

Table A.1 Optimized Interior Designs for 28-ft. Cross-section With Homogeneous Girder Configuration in Accordance with $3^{\text {rd }}$ Edition of Specifications

Table A.2 Optimized Interior Designs with Partially Stiffened

Web for 28-ft. Cross-section with Homogeneous Girder

Configuration in Accordance with $3^{\text {rd }}$ Edition of

Specifications

Table A.3 Optimized Interior Designs for 28-ft. Cross-section With Hybrid Girder Configuration in Accordance with $3^{\text {rd }}$ Edition of Specifications

Table A.4 Optimized Interior Designs Failing the L/800 Deflection Limit for 28-ft. Cross-section with Hybrid Girder Configuration in Accordance with $3^{\text {rd }}$ Edition of Specifications

Table A.5 Optimized Interior Designs with Partially Stiffened Web for 28-ft. Cross-section with Hybrid Girder Configuration in Accordance with $3^{\text {rd }}$ Edition of Specifications

Table A.6 Optimized Interior Rolled Beams for 28-ft. Cross-section in Accordance with $3^{\text {rd }}$ Edition of Specifications

Table A.7 Optimized Interior Designs for 34-ft. Cross-section With Homogeneous Girder Configuration in Accordance with $3^{\text {rd }}$ Edition of Specifications

Table A.8 Optimized Interior Designs with Partially Stiffened

Web for 34-ft. Cross-section with Homogeneous Girder Configuration in Accordance with $3^{\text {rd }}$ Edition of Specifications 
Table A.9 Optimized Interior Designs for 34-ft. Cross-section With Hybrid Girder Configuration in Accordance with $3^{\text {rd }}$ Edition of Specifications 128

Table A.10 Optimized Interior Designs Failing the L/800 Deflection Limit for 34-ft. Cross-section with Hybrid Girder Configuration in Accordance with $3^{\text {rd }}$ Edition of Specifications

Table A.11 Optimized Interior Designs with Partially Stiffened

Web for 34-ft. Cross-section with Hybrid

Girder Configuration in Accordance with $3^{\text {rd }}$ Edition of Specifications

Table A.12 Optimized Interior Rolled Beams for 34-ft. Cross-section in Accordance with $3^{\text {rd }}$ Edition of Specifications

Table A.13 Optimized Exterior Designs for 28-ft. Cross-section With Homogeneous Girder Configuration in Accordance with $3^{\text {rd }}$ Edition of Specifications

Table A.14 Optimized Exterior Designs with Partially Stiffened Web for 28-ft. Cross-section with Homogeneous Girder Configuration in Accordance with $3^{\text {rd }}$ Edition of Specifications

Table A.15 Optimized Exterior Designs for 28-ft. Cross-section With Hybrid Girder Configuration in Accordance with $3^{\text {rd }}$ Edition of Specifications

Table A.16 Optimized Exterior Designs Failing the L/800 Deflection Limit for 28-ft. Cross-section with Hybrid Girder Configuration in Accordance with $3^{\text {rd }}$ Edition of Specifications

Table A.17 Optimized Exterior Designs with Partially Stiffened Web for 28-ft. Cross-section with Hybrid Girder Configuration in Accordance with $3^{\text {rd }}$ Edition of Specifications

Table A.18 Optimized Exterior Rolled Beams for 28-ft. Cross-section in Accordance with $3^{\text {rd }}$ Edition of Specifications

Table A.19 Optimized Exterior Designs for 34-ft. Cross-section With Homogeneous Girder Configuration in Accordance with $3^{\text {rd }}$ Edition of Specifications 
Table A.20 Optimized Exterior Designs with Partially Stiffened Web

for 34-ft. Cross-section with Homogeneous Girder

Configuration in Accordance with $3^{\text {rd }}$ Edition of

Specifications

Table A.21 Optimized Exterior Designs for 34-ft. Cross-section With

Hybrid Girder Configuration in Accordance with

$3^{\text {rd }}$ Edition of Specifications

Table A.22 Optimized Exterior Designs with Partially

Stiffened Web for 34-ft. Cross-section with Hybrid Girder

Configuration in Accordance with $3^{\text {rd }}$ Edition of

Specifications

Table A.23 Optimized Exterior Rolled Beams for 34-ft. Cross-section

in Accordance with $3^{\text {rd }}$ Edition of Specifications

Table A.24 Limited Interior Plate Size Designs for 28-ft. Cross-section with Homogeneous Girder Configuration in Accordance with $3^{\text {rd }}$ Edition of Specifications

Table A.25 Limited Interior Plate Size Designs for 28-ft. Cross-section with Hybrid Girder Configuration in Accordance

with $3^{\text {rd }}$ Edition of Specifications

Table A.26 Limited Interior Plate Size Designs for 34-ft. Cross-section with Homogeneous Girder Configuration in Accordance with $3^{\text {rd }}$ Edition of Specifications.

Table A.27 Limited Interior Plate Size Designs for 34-ft. Cross-section with Hybrid Girder Configuration in Accordance

with $3^{\text {rd }}$ Edition of Specifications

Table A.28 Limited Exterior Plate Size Designs for 28-ft. Cross-section with Homogeneous Girder Configuration in Accordance

with $3^{\text {rd }}$ Edition of Specifications

Table A.29 Limited Exterior Plate Size Designs for 28-ft. Cross-section with Hybrid Girder Configuration in Accordance with $3^{\text {rd }}$ Edition of Specifications

Table A.30 Limited Exterior Plate Size Designs for 34-ft. Cross-section with Homogeneous Girder Configuration in Accordance with $3^{\text {rd }}$ Edition of Specifications 
Table A.31 Limited Exterior Plate Size Designs for 34-ft. Cross-section with Hybrid Girder Configuration in Accordance with $3^{\text {rd }}$ Edition of Specifications 


\section{List of Figures}

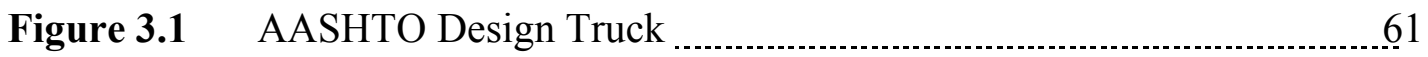

Figure 4.1 Typical Girder Elevation …..................................................... 73

Figure 4.2 Bridge Cross-section with 28-ft. Clear Roadway Width …............... 73

Figure 4.3 Bridge Cross-section with 34-ft. Clear Roadway Width _.................. 73

Figure 4.4 Exterior Girder Designs, 28-ft. Cross Section

$140 \mathrm{ft}$. Span Length, L/D vs. Weight 74

Figure 4.5 Exterior Girder Designs, 28-ft. Cross Section

$120 \mathrm{ft}$. Span Length, L/D vs. Weight 74

Figure 4.6 Exterior Girder Designs, 28-ft. Cross Section

$100 \mathrm{ft}$. Span Length, L/D vs. Weight 75

Figure 4.7 Exterior Girder Designs, 28-ft. Cross Section

$80 \mathrm{ft}$. Span Length, L/D vs. Weight 75

Figure 4.8 Exterior Girder Designs, 28-ft. Cross Section

$60 \mathrm{ft}$. Span Length, L/D vs. Weight 76

Figure 4.9 Interior Girder Designs, 28-ft. Cross Section

140 ft. Span Length, L/D vs. Weight 76

Figure 4.10 Interior Girder Designs, 28-ft. Cross Section $120 \mathrm{ft}$. Span Length, L/D vs. Weight 77

Figure 4.11 Interior Girder Designs, 28-ft. Cross Section $100 \mathrm{ft}$. Span Length, L/D vs. Weight 77

Figure 4.12 Interior Girder Designs, 28-ft. Cross Section $80 \mathrm{ft}$. Span Length, L/D vs. Weight 78

Figure 4.13 Interior Girder Designs, 28-ft. Cross Section $60 \mathrm{ft}$. Span Length, L/D vs. Weight 78

Figure 4.14 Interior vs. Exterior Girder Designs, 28-ft. Homogeneous Cross Section $140 \mathrm{ft}$. Span Length, L/D vs. Weight 79 
Figure 4.15 Interior vs. Exterior Girder Designs, 28-ft. Homogeneous

Cross Section $120 \mathrm{ft}$. Span Length, L/D vs. Weight

Figure 4.16 Interior vs. Exterior Girder Designs, 28-ft. Homogeneous

Cross Section 100 ft. Span Length, L/D vs. Weight 80

Figure 4.17 Interior vs. Exterior Girder Designs, 28-ft. Homogeneous

Cross Section $80 \mathrm{ft}$. Span Length, L/D vs. Weight

Figure 4.18 Interior vs. Exterior Girder Designs, 28-ft. Hybrid Cross Section

$140 \mathrm{ft}$. Span Length, L/D vs. Weight

Figure 4.19 Interior vs. Exterior Girder Designs, 28-ft. Hybrid Cross Section $120 \mathrm{ft}$. Span Length, L/D vs. Weight

Figure 4.20 Interior vs. Exterior Girder Designs, 28-ft. Hybrid Cross Section $100 \mathrm{ft}$. Span Length, L/D vs. Weight 82

Figure 4.21 Interior vs. Exterior Girder Designs, 28-ft. Hybrid Cross Section $80 \mathrm{ft}$. Span Length, L/D vs. Weight 82

Figure 4.22 Partially Stiffened Web Exterior Girder Designs, 28-ft. $140 \mathrm{ft}$. Span Length, L/D vs. Weight 83

Figure 4.23 Partially Stiffened Web Exterior Girder Designs, 28-ft. $120 \mathrm{ft}$. Span Length, L/D vs. Weight 83

Figure 4.24 Partially Stiffened Web Exterior Girder Designs, 28-ft. $100 \mathrm{ft}$. Span Length, L/D vs. Weight 84

Figure 4.25 Partially Stiffened Web Interior Girder Designs, 28-ft. $140 \mathrm{ft}$. Span Length, L/D vs. Weight 84

Figure 4.26 Partially Stiffened Web Interior Girder Designs, 28-ft. $120 \mathrm{ft}$. Span Length, L/D vs. Weight 85

Figure 4.27 Partially Stiffened Web Interior Girder Designs, 28-ft. $100 \mathrm{ft}$. Span Length, L/D vs. Weight 85

Figure 4.28 Weight Comparisons of Exterior Rolled Beam Design for 28-ft Cross-section $140 \mathrm{ft}$. Span Length 86

Figure 4.29 Weight Comparisons of Exterior Rolled Beam Design for 28-ft Cross-section $120 \mathrm{ft}$. Span Length 86 
Figure 4.30 Weight Comparisons of Exterior Rolled Beam Design for 28-ft Cross-section $100 \mathrm{ft}$. Span Length

Figure 4.31 Weight Comparisons of Exterior Rolled Beam Design for 28 -ft Cross-section $80 \mathrm{ft}$. Span Length 87

Figure 4.32 Weight Comparisons of Exterior Rolled Beam Design for 28 -ft Cross-section $60 \mathrm{ft}$. Span Length 88

Figure 4.33 Weight Comparisons of Exterior Rolled Beam Design for 28 -ft Cross-section $40 \mathrm{ft}$. Span Length 88

Figure 4.34 Weight Comparisons of Interior Rolled Beam Design for 28-ft Cross-section $140 \mathrm{ft}$. Span Length 89

Figure 4.35 Weight Comparisons of Interior Rolled Beam Design for 28 -ft Cross-section $120 \mathrm{ft}$. Span Length 89

Figure 4.36 Weight Comparisons of Interior Rolled Beam Design for 28 -ft Cross-section $100 \mathrm{ft}$. Span Length 90

Figure 4.37 Weight Comparisons of Interior Rolled Beam Design for 28 -ft Cross-section $80 \mathrm{ft}$. Span Length 90

Figure 4.38 Weight Comparisons of Interior Rolled Beam Design for 28 -ft Cross-section $60 \mathrm{ft}$. Span Length 91

Figure 4.39 Weight Comparisons of Interior Rolled Beam Design for 28-ft Cross-section $40 \mathrm{ft}$. Span Length 91

Figure 4.40 Deflection comparisons for Exterior Girder Design Alternatives, Deflection vs. L/D, $140 \mathrm{ft}$. span Length 92

Figure 4.41 Deflection comparisons for Exterior Girder Design Alternatives, Deflection vs. L/D, $120 \mathrm{ft}$. span Length 92

Figure 4.42 Deflection comparisons for Exterior Girder Design Alternatives, Deflection vs. L/D, $100 \mathrm{ft}$. span Length 93

Figure 4.43 Deflection comparisons for Exterior Girder Design Alternatives, Deflection vs. L/D, $80 \mathrm{ft}$. span Length 93 
Figure 4.44 Deflection comparisons for Exterior Girder Design Alternatives, Deflection vs. L/D, $60 \mathrm{ft}$. span Length

Figure 4.45 Deflection comparisons for Interior Girder Design

Alternatives, Deflection vs. L/D, $140 \mathrm{ft}$. span Length 94

Figure 4.46 Deflection comparisons for Interior Girder Design Alternatives, Deflection vs. L/D, $120 \mathrm{ft}$. span Length 95

Figure 4.47 Deflection comparisons for Interior Girder Design Alternatives, Deflection vs. L/D, $100 \mathrm{ft}$. span Length 95

Figure 4.48 Deflection comparisons for Interior Girder Design Alternatives, Deflection vs. L/D, $80 \mathrm{ft}$. span Length 96

Figure 4.49 Deflection comparisons for Interior Girder Design Alternatives, Deflection vs. L/D, $60 \mathrm{ft}$. span Length 96

Figure 5.1 Typical Girder Elevation 75

Figure 5.2 Bridge Cross-section with 28-ft. Clear Roadway Width 75

Figure 5.3 Bridge Cross-section with 34-ft. Clear Roadway Width 75

Figure 5.4 Exterior Girder Designs, 28-ft. Cross Section $140 \mathrm{ft}$. Span Length, L/D vs. Weight 76

Figure 5.5 Exterior Girder Designs, 28-ft. Cross Section $120 \mathrm{ft}$. Span Length, L/D vs. Weight 76

Figure 5.6 Exterior Girder Designs, 28-ft. Cross Section $100 \mathrm{ft}$. Span Length, L/D vs. Weight 77

Figure 5.7 Exterior Girder Designs, 28-ft. Cross Section $80 \mathrm{ft}$. Span Length, L/D vs. Weight 77

Figure 5.8 Exterior Girder Designs, 28-ft. Cross Section $60 \mathrm{ft}$. Span Length, L/D vs. Weight 78

Figure 5.9 Interior Girder Designs, 28-ft. Cross Section $140 \mathrm{ft}$. Span Length, L/D vs. Weight 78

Figure 5.10 Interior Girder Designs, 28-ft. Cross Section 120 ft. Span Length, L/D vs. Weight 79 
Figure 5.11 Interior Girder Designs, 28-ft. Cross Section $100 \mathrm{ft}$. Span Length, L/D vs. Weight

Figure 5.12 Interior Girder Designs, 28-ft. Cross Section $80 \mathrm{ft}$. Span Length, L/D vs. Weight 80

Figure 5.13 Interior Girder Designs, 28-ft. Cross Section $60 \mathrm{ft}$. Span Length, L/D vs. Weight 80

Figure 5.14 Interior vs. Exterior Girder Designs, 28-ft. Homogeneous Cross Section $140 \mathrm{ft}$. Span Length, L/D vs. Weight 81 


\section{Chapter 1}

\section{Introduction}

\subsection{Background}

A considerable number of bridges in West Virginia are structurally deficient or functionally obsolete. According to the West Virginia Bridge Data released by the Maintenance Division in July 2003, 24.4\% of all bridges in the state with spans of 100 feet or less is functionally obsolete and $14.9 \%$ are structurally deficient. There are not adequate funds to replace or repair all of these structures. Hence, the development of standardized bridge plans could provide a means to an economical design process that will help facilitate and expedite the replacement of some of these structures.

Standardized plans for short-span bridge structures have been developed for various types of structures in the past. Plans for concrete, timber and steel structures have been successfully developed, as well as plans for abutments, piers and pier caps. The focus of this study is to develop a short-span steel I-girder design package according to the Third Edition of the AASHTO LRFD Bridge Design Specifications (AASHTO 2004). A series of short-span design girders sections will include homogeneous, hybrid configurations as well as rolled beam sections. 


\subsection{Objectives}

This study focused on developing a design package of standardized short-span steel I-girders to provide a more time efficient design process and to save time and resources during construction of existing bridge replacements as well as the construction of new structures. The standardized bridge plans include a series of steel I-girders for spans length ranging from 40 to 140 feet. During the course of this study, two sets of designs were developed: an optimized design study and a limited plate size study.

The optimized designs were completed based on girder weight and ranged for span lengths of 40 to 140 feet, in increments of 5 feet. The design parameters incorporated three girder configurations: homogeneous, hybrid and rolled beams. Sections were developed for three span-to-depth ratios, 20, 25, and 30 unless the minimum web height of 24 inches restricted it. Also, girders were designed based on location, interior and exterior as well as stiffened and un-stiffened.

In addition to the optimized design package, a limited plate size study was conducted. The main goal of this research was to investigate the possible economical advantages of purchasing certain, more readily available plate thicknesses in bulk. This study also included designs ranging in span length from 40 to 140 feet, in 5 feet increments. Plate thicknesses were limited to the following:

- Web depths: 24", 32", 40" and 48" 


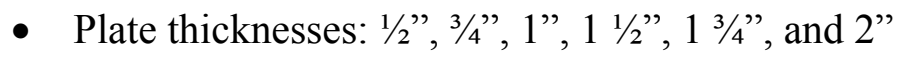

The limited plate study also incorporated interior and exterior designs for stiffened and un-stiffened webs with the above mentioned three girder configuration.

\subsection{Organization of Thesis}

This research study contains six chapters. The second chapter describes practices to design more economical steel I-girders, in addition to rapid construction techniques currently employed in bridge construction practice.

Third chapter reviews the fundamentals of the Third Edition of the AASHTO LRFD Bridge Design Specifications for the design of steel I-girder sections. This chapter describes design loads, lateral distribution factors and the summary of the three main design load cases.

The fourth chapter presents a parametric study concentrated on optimized shortspan steel I-girder design package. This section describes the design process as well as the results and observations for the above mentioned three girder configurations at two girder locations. Chapter five discusses the limited plate size design study and evaluates the economy of the effort. This chapter also compares the optimized design study with the limited plate size design alternatives. Lastly, chapter six presents the summary and conclusions of this study. 


\section{Chapter 2}

\section{Literature review}

\subsection{Background}

A considerable number of bridges are either structurally deficient or functionally obsolete. The repair or replacement of these structures is one of the highest priorities, but necessary funds are rarely available. Consequently, the bridge industry is focusing on design techniques that provide a quality and cost effective product in relatively short amount of time, with less maintenance requirement and a longer life span. This could be achieved by developing standardized bridge plans and time saving construction techniques.

Standardized bridge plans significantly reduce design time, increase and provide cost effective solutions in the nation's effort to repair and upgrade the infrastructure. Modern computing power and the right software selection (MS Access and Visual Basic software packages) makes standardized bridge plans readily available for practical design level purposes (Vijaya 2004).

The main advantages of standardized bridge plans are time saving both in design and construction repeatedly for various projects. Time efficient design and construction will let DOTs to operate cost effectively nationwide. Reduced design and construction 
leads to wide spread implementation of advanced, cost effective details (Holt and Medlock 2004). Savings in construction cost are also realized, because the contractor's familiarity with the plans leads to more accurate bidding procedure and time and cost savings in form work as well.

This chapter discusses some of the general steel I-girder design guidelines, standardized bridge plans and rapid construction techniques currently being implemented.

\subsection{General Bridge Design Guidelines}

Cost effective and practical bridge design is often achieved by weight optimization of the superstructure. The success depends on the design of optimized girders and careful detailing as well. Lack of attention to details leads to significant cost increase without adding value to the structure. This section presents an overview of common practices in the bridge industry that have historically improved steel-stringer bridge designs.

\subsubsection{Weight Optimization}

The design of optimized steel I-girder sections based on girder weight is the analytical method of developing cost effective bridge systems. However, in reality, weight optimized designs could be more costly in certain regions, or the availability of certain steel markets. Several additional steps shall be taken to reduce the cost of bridges. 
The designer is encouraged to solicit input from steel bridge fabricators to improve the cost-effectiveness of the design and details (Steel Works 2004). Designers should be knowledgeable of fabricators and contractors who may be potential bidders on the project. This collaboration will save significant girder cost and will incorporate practicality in the design process.

\subsubsection{Flange Transitions}

An economical individual girder shipping piece has one to three thicknesses per flange, with each flange having zero to two shop-welded splices. Minimizing the number of flange plate thicknesses for a project simplifies fabrication and inspection operations. Larger quantities of plate cost less; hence by minimizing different plate thicknesses cost savings could be realized. In order to achieve that, similar sizes of flanges obtained during preliminary design should be grouped to minimize the number of plate thicknesses (AASHTO/NSBA 2003).

Efficiently locating thickness transitions in plate girder flanges is a matter of plate length availability and the economics of welding and inspecting a splice compared to extending the thicker plate. For a flange transition to be economical, 800 to 1000 pounds must be saved to offset fabrication cost (TxDOT 2002). The cost saved by eliminating the splice may more than offset the cost of the heavier plate. Using a constant width flange rather changing plate thickness will reduce fabrication cost by as much as 35 percent in a field section (AASHTO/NSBA 2003). 


\subsubsection{Number of Girders Lines}

Research has shown that using wider girder spacing could provide significant cost savings. Clingenpeel and Barth (2003) conducted a parametric design study on a three span continuous bridge system and showed that cost savings of 13 percent was realized when selecting a 7-girder system instead of a 9-girder system. Another advantage to wider girder spacing is lower structural steel weight, fewer girders and cross frames to fabricate, erect, coat and inspect.

Reduced number of girders will lead to reduced time of fabrication and erection, fewer structural components to purchase, install and maintain. One of them is the additional concrete and reinforcing in the deck is required and the special formwork cost to form the deck. Another consideration is the stability and redundancy of the structure during future re-decking. In that case, a minimum number of four girders are required keeping in mind that the maximum optimal girder spacing is on the order of 10 feet. Girder depth limitations based on vertical clearance may restrict optimizing the number of girders (AASHTO/NSBA 2003).

\subsubsection{Optimal Deck Forming}

Manufacturing and construction practices among fabricators and contractors vary; therefore it is recommended to provide optional details for items such as cross frames, integral/joint-less abutments, and deck forms. Preferences for section type and details 
vary among fabricators and erectors depending on the equipment available, shipping considerations and experience (Steel Works 2004). This will provide a cost effective fabrication and construction.

\subsubsection{Uncoated Weathering Steel}

It is recommended that consideration be given to the use of uncoated weathering steel where appropriate. The use of uncoated weathering steel typically provides initial cost savings of $10 \%$ or more, and life-cycle cost savings of at least $30 \%$ over the life of the structure. The suitability of weathering steel should be evaluated before specifying a paint system, considering future re-painting process (Steel Works 2003). Environmental benefits also result from the use of this material. The reduction in initial painting reduces emissions of volatile organic compounds (VOC) and the elimination of removal of the coating and disposal of contaminated blast cleaning debris over the life span of the structure is another significant environmental benefit.

However, where painting is required, weathering steel should not be considered because of the higher cost. Although the use of weathering steel is applicable in most environments, the engineer should consider that weathering steel does not perform well in humid environments with corrosive chemicals (TxDOT 2002). 


\subsubsection{High Performance Steel}

High performance steel has the potential to decrease costs and increase productivity for building steel bridges. It has been shown to provide 18 percent cost savings and 28 percent weight savings compared to traditional steel (NSBA 2005). The application of high performance steels could lead to more economical designs. The higher strength and excellent weld-ability of this steel are especially advantageous for hybrid girders. According to a design optimization study, done by Clingenpeel and Barth, the most efficient material configuration was found to be the Hybrid configuration, which consists of HPS 70W tension flange and $50 \mathrm{ksi}$ compression flange and web in the positive bending region and HPS 70W flanges and a $50 \mathrm{ksi}$ web in the negative bending region. The most economical design was always a hybrid configuration for all girder spacing considered over the conventional $50 \mathrm{ksi}$ homogeneous designs. (Clingenpeel 2001)

New optimized shapes, designed to replace the traditional I-girders and box shapes, will further realize the full benefit of the strength and weldability of high performance steel. One of these new shapes was an I-girder with a corrugated steel web, developed by Advanced Technology for Large Structural Systems Center at Lehigh University and Modjeski and Masters, Inc. It provides increased web stability, reduced web thickness without the need for web stiffeners (NSBA 2005). 
Among the disadvantages of high performance steel is the higher cost and the design parameters that limit the wide spread use of this material. Limits states that depend on girder geometry rather than steel strength, such as the live-load deflection limit and fatigue limit state, decrease the economy of high performance steel. When the deflection limit of L/800 is neglected, significant weight/cost savings may be realized. Thus, given that the design passes all strength, fatigue and constructability requirements, more reasonable serviceability limits could be used to achieve lighter limits (Clingenpeel 2001).

\subsubsection{Substructure Design}

When considering a cost effective bridge system, a well designed substructure and superstructure are both main priorities. The location of the bridge is essential when determining the initial and life-cycle cost of the structure. Therefore, during the design a bridge system, the selection for the type of substructure should be an integral part of the weight optimization process.

\subsubsection{Expansion Joints}

One of the more important aspects of design, reduction or elimination of roadway expansion devices and associated bearings, is consistently overlooked by bridge designers. Joints and bearings are expensive to buy, install, maintain and replace. Even waterproof joints will leak, allowing water or salt-laden to pour through the joint and to 
accelerate corrosion damage to girder ends, bearings and reinforced concrete structures. Integral abutments only incorporate one row of piles, hence it is more cost effective and faster to construct. Joint-less abutments also reduce the end span ratio and provide protection against uplift conditions with the weight of the abutment. They have added redundancy and capacity for all types of catastrophic events (AISI 1996). Therefore, an integral abutment with a joint-less deck should be used wherever it's possible to ensure low initial cost and future maintenance.

\subsubsection{Constructability}

Emphasis on construction is essential when considering a well designed bridge system. Often time structures are designed with lack of attention to constructability, and the result is a very difficult or even impossible to construct structure. Therefore, it is essential that the strength and stability of the structure is investigated during each stage of construction. To economically satisfy these requirements, the designer should avoid narrow compression flanges because the structure may require added cross frames or temporary bracing during construction.

\subsubsection{Inspect-ability}

Bridge systems are required to be inspected at least every two years. For most of the bridges, inspection could be performed from a rigging truck or some kind of elevated platform. In case of box girders, the designers should adequately leave enough space 
inside the beam for inspection purposes. Hence, the specifications should determine bridge designs that allows for convenient future inspections.

\subsection{Summary of Standardized Bridge Plans}

Standardized bridge packages are practical design solutions and gaining popularity among organizations. They save design and possibly construction time and provide design clarity. This section lists some of the standardized design packages.

\subsubsection{AISI Short Span Steel Bridge Plans and Software}

The American iron and Steel Institute has developed a comprehensive set of standardized short-span steel bridge plans and design aid software to allow customers to generate preliminary designs as well as final designs. The design aid was developed with input from fabricators and designers to reduce cost of fabrication and minimize design time (AISI 1998). This bridge package includes over 1100 designs for non-skewed, single and multiple span bridges.

The design plans include spans ranging from 20 to 120 feet in five feet increments and offers seven superstructure cross section layouts: 24, 28, 34, 40, and 44 feet (AISI 1998). The plans offer homogeneous, 50 ksi un-stiffened and stiffened plate girders, noncomposite or composite rolled beams and composite rolled beams with welded or endbolted cover plates. The document also incorporates light weight and normal weight 
concrete decks, quantity tables for concrete, rebar and steel and details for elastomeric bearings as well. The girders were designed utilizing Load Factor Design method of the $16^{\text {th }}$ Edition of AASHTO Standard Specifications for Highway Bridges, including 1997 Interim Specifications (AISI 1998).

\subsubsection{TxDOT Bridge Standards}

Standardized concrete bridge plans are widely used by the Texas Department of Transportation (TxDOT), since more than 90 percent of Texas bridges are no longer than 120 feet.. The benefits of using standardized bridges include reduced design effort, widespread implementation of economically proven construction technologies, and reduced construction costs (Holt and Medlock 2004).

This standardized bridge package include pre-stressed I-beams, box beams, slab beams, and double T-beams along with cast in place and precast culverts. Cross sections accommodate for 24, 28, 30, 38, and 44 feet along with modest skews (less then 45 degrees). Drawings cover all superstructure and substructure details. Most of the bridges are designed by Load and Resistance Factor Design and TxDOT is taking steps to provide standard drawings representing LRFD-based designs for all the bridges. 


\subsubsection{Standardized Bridge Plans}

A research effort from the University of Alabama focused on the development of a computer-aided tool that facilitates selection of standardized bridge systems for rapid design and replacement or construction of bridges (Gopu 2004). The database was developed using Microsoft Access and Microsoft Visual Basics and contains a collection of standard drawings available from various DOT-s across the nation. The information package contains a large amount of standardized plans and is a useful tool for bridge designers.

\subsection{Innovative Ideas for Rapid Construction}

Rapid construction techniques combined with standardized bridge plans provide for efficient construction of new bridges and the replacement of existing structures. The benefits of accelerated bridge constructions are well known. They minimize traffic disruption, improve work zone safety and also minimize environmental impact. In addition to that, off site construction of pre-fabricated elements can improve quality, constructability and lower life cycle cost (Concrete Bridge Conference Workshop 2006). The next section includes some of the innovative ideas of accelerated bridge construction alternatives. 


\subsubsection{Superstructure Systems}

The typical sequence of constructing bridge superstructures is to erect the concrete or steel beams, place temporary formwork or stay in place panels, place deck reinforcement, cast deck concrete and remove formwork if necessary. The elimination of formwork will accelerate construction and improve safety. One of the alternatives is a prefabricated partial deck system placed on concrete or steel girders. After the beams are erected, the edges of each deck unit almost touch each other so there is no need for additional formwork for the cast in place concrete. This system is applicable to prestressed concrete beams as well and has been implemented in Germany with great success.

Another superstructure alternative is the French Poutre Dalle system. It consists of shallow, pre-cast, pre-stressed concrete inverted T-beams. The beams are placed next to each other connected with a longitudinal joint and covered with cast in place concrete. Continuity is accomplished through the 180-degree hooks that protrude from the sides of the webs. The hooks overlap those from the adjacent beam and positioned precisely to avoid confusion at the job site. This system is appropriate for span lengths from 20 to 82 feet, but can be extended up to 105 feet. A typical bridge can be erected in one day and among the common advantages of rapid construction, this system does not require skilled labor for erection and has a thinner deck resulting in higher vertical clearance. 
A similar system is implemented in France, called Dalle Preflex System, but uses steel I-beams with their bottom flanges pre-cast in thick pre-stressed concrete slab. Hooked bars passing through the steel web overlap from the adjacent members to provide lateral transverse reinforcement. Cast in place concrete is used to complete the superstructure. This system has similar advantages and is proprietary in Europe.

\subsubsection{Deck Systems}

Exodermic bridge deck is a composite modular system that is lightweight and strong (NCHRP 2004). It consists of a reinforced concrete slab on top of an unfilled steel grid providing composite action between components. These types of decks are 50 to 60 percent lighter than the conventionally reinforced concrete decks but provide superior economy and durability.

One of the forms of bridge decks construction is the use of full depth prefabricated concrete decks. It is widely used in Europe because it reduces construction time and eliminates formwork. The deck panels are connected to steel I-girders through the use of studs located in pockets of in the concrete deck slab. Screws located in the panels are used to adjust elevations. The panels sit on elastomeric pads that also provide a seal for the grouting between the panels and the steel I-girder.

Another deck system is the Hybrid Steel-Concrete Deck System developed by Japanese engineers. The steel component of the system consists of bottom and side stay- 
in-place formwork and transverse beams. The transverse beams span over the longitudinal beams and beyond the fascia beam for the slab overhang. The bottom flanges of the transverse beams support the steel formwork for the bottom surface of the slab. The formwork is sloped to provide a haunched section over the girders. The longitudinal deck reinforcement is supported by the top flange of the transverse beams. Steel studs welded to the beam flange connect the deck and the beams. When filled with concrete, the system acts as a composite deck system. The system allows rapid placement with a small-capacity crane of a lightweight deck stay-in-place formwork system complete with reinforcement, including the overhang.

\subsubsection{Substructure Systems}

The Sumitomo Precast form for resisting Earthquakes and for Rapid construction (SPER) system is a method developed by Sumitomo Mitsui Construction Company for rapid construction of short and tall bridge piers in seismic regions using stay-in-place 3.9in thick pre-cast concrete panels as both formwork and structural elements. For short solid piers, panels with pre-installed cross ties serve as exterior formwork. Segments are stacked on top of each other using epoxy joints and filled with cast-in-place concrete to form a solid pier. For taller hollow piers, inner and outer forms are used to produce a hollow section. To reduce weight and size for hauling, panels form two channel-shaped sections. Lateral reinforcement is embedded in the channel sections and joined together in the field using couplers. After inner and outer pre-cast forms are set around vertical reinforcement, cross ties (transverse reinforcement) are placed and concrete is cast within 
the section. Use of high-strength bars for cross ties reduces congestion and fabrication time. Special details are used to transfer the force from the transverse reinforcement into the panels. Cast-in-place concrete is used to connect the piers to the superstructure. The system can shorten construction time to 60 to 70 percent of the time required for conventional cast-in-place construction for 33 -ft tall piers. This is attributed to the elimination of formwork and reduction in curing time. For 50-m (164-ft) tall piers, reduction in placement time for lateral reinforcement and cross ties resulted in a one-third decrease in construction time.

\subsubsection{Fiber Reinforced Polymer Elements}

Fiber reinforced polymers composite materials have shown potential as alternative bridge construction materials compared with conventional ones. Their advantage is their high strength, low density, better durability and corrosion resistance versus traditionally reinforced concrete decks (NCHRP 2004). Construction time is about 10 percent of the conventional concrete decks and requires construction crew. They tend to land themselves to pre-fabrication and mass production; they are easily formed into structural shapes, conveniently transported and erected. Two types of FRP decks are commercially available, sandwich and pultruded shapes.

Sandwich construction implies the use of strong stiff face sheets and low density, bonded core material that separates the face sheets and ensures composite action between components. Because of the ease of construction, this alternative provides great 
flexibility in design for various depths and deflection requirements. The other FRP deck design, the pultruded decks are constructed using assemblies of adhesive-bonded pultruded shapes. Such shapes could be economically produced and design flexibility comes from the orientation and type of the fibers (NCHRP 2004).

Although FRP decks offer a wide spectrum of advantages, they are still under research. This alternative in order to become widely used requires quality control, quality assurance and standardized tests to be implemented (NCHRP 2004).

\subsection{Summary}

The majority of the U.S. bridge inventory may be defined as short-span structures. Therefore, rapid construction techniques combined with innovative material selection outlines the path for designing new bridges and rehabilitate existing inventory. This section detailed some of the bridge design alternatives to cut down design and construction costs, discussed various efforts towards standardized bridge packages, and described some innovative accelerated bridge construction techniques. This study focuses on developing a standardized design package according to the general bridge design trends. 


\section{Chapter 3}

\section{Fundamental Steel Bridge Design Aspects of the AASHTO LRFD Bridge Design Specifications}

\subsection{Introduction}

This section summarized the American Association of State Highway Transportation Officials (AASHTO) Load and Resistance Factor Design (LRFD) Specifications for composite steel I-girder bridges. These guidelines provide information about design loads, lateral distribution of live loads, and member strength and service limit states.

\subsection{Design Loads}

I-girder sections are designed to carry a combination of factored dead load, vehicular live loads, and estimated construction loads. Dead loads include the self weight of the structure, and any additional loads that are associated with any future wearing surface, utility loads and possible widening. The live load portion involves the static and dynamic load exerted by the design vehicles and the lane load. 


\subsubsection{Types of Design Loads}

\subsubsection{Dead Loads}

The dead loads consists of a combination of the non-composite dead loads (DC1), composite dead loads (DC2), and the dead load of the non-integral wearing surface (DW). DC1 includes the dead weight of the steel section, concrete deck and haunch, stay in place deck forms, and miscellaneous steel accounted for cross frames, shear studs and stiffeners. DC2 consist of barriers, sidewalks, and railings and it is applied after the deck becomes composite. DW is the dead load of the future wearing surface and utilities.

These designs are performed assuming composite action between the deck and the supporting I-girders, meaning that the deck and the girder act as a single component once the composite action takes place. The strain diagram of the separate components varies linearly; hence there is no slip between the interfaces of the steel and the deck. This is achieved by the use of shear studs. They are welded on the top flange and provide the transfer of horizontal forces between the deck and the steel section. The long term section properties are computed using three times the modular ratio to account for the shrinkage and creep of the concrete with time. DC2 loads are applied to the long term section. 


\subsubsection{Design Vehicular Loads}

The design live load, described in Article 3.6.1.2.2 as HL-93 is a combination of the design truck or design tandem combined with the design lane load. The design truck, shown in Figure 3.1, is consists of a front axle load of 8 kips and two additional axle load of 32 kips. The front axle is spaced 14 feet, while the two back axles have a variable spacing between 14 feet to 30 feet apart. The design tandem has double axes with 25 kip loads spaced at four feet as detailed in Article 3.6.1.2.3. Transverse axle spacing is 6 feet for both design truck and design tandem.

The design lane load is described in Article 3.6.1.2.4 and is consisted of a uniformly distributed load of $0.64 \mathrm{kips}$ per liner foot. The width of the design lane is 10 feet. Design lane load is not subjected to dynamic load allowance.

\subsubsection{Construction Loads}

A complete analysis of a bridge system includes the design of the components during construction stages as well. Hence, the bending moments and shear forces occurring in the structure during each construction stage has to be checked against the resistance of the system. Additional construction loads applied to the overhang brackets induce lateral flange bending of the compression flange of the exterior girder. Typical construction loads are the following: overhang deck, overhang deck forms, screed rails, railing, walkway, and finishing machine. 


\subsubsection{Limit State Design Loads}

Structural components made of steel shall be investigated for each phase that may be critical during construction and the service life of the system. Therefore, the specifications mandate structural components to be proportioned to satisfy the requirements at strength, service, construction, and fatigue limit states. The following is a brief description of each limit state and its load requirements.

\subsubsection{Loading for Strength Limit State}

To evaluate the strength limit state, the structure is subjected to HL-93 loading combination. As previously described, it is a combination of a design truck or design tandem with the design lane load. Depending on the specific Strength Limit State (I, II, III, IV, V), different load factors are applied to the moment and shear envelopes (DC1, DC2, DW and LL). In this study the following strength limit states are investigated: Strength I limit state, which basic load combination is relating to the normal vehicular use without wind, and Strength III limit state for a structure exposed to wind velocities higher than $55 \mathrm{Mph}$.

- $\quad$ STRENGTH I: $\quad 1.25 \mathrm{DC}+1.50 \mathrm{DW}+1.75(\mathrm{LL}+\mathrm{IM})$

- $\quad$ STRENGTH III: $\quad 1.25 \mathrm{DC}+1.50 \mathrm{DW}+1.40 \mathrm{WS}$ 


\subsubsection{Loading for Service Limit State}

Service limit state loading requirements are divided into permanent deformations check and live-load deflection check. The above mentioned HL-93 loading is applied to evaluate permanent deformations and web requirement. The live-load deflection criteria apply the bigger of the following two loadings:

- The design truck

- $25 \%$ of design truck plus the design lane load

\subsubsection{Loading for Fatigue Limit State}

Fatigue and fracture load combination is related to a repetitive gravitational and vehicular live load and dynamic responses under a single design truck with axle spacing of 30 feet described in Article 3.6.1.4.1.

\subsection{Live-Load Distribution Factors}

The live-load distribution factors determine the portion of the load that is carried by a particular girder. The distribution factors are applied to vehicular and lane liveloads. In determining the distribution factors, refined methods of analysis or approximate equations could be utilized. In this study approximate equations method are utilized according to the specifications in Article 4.6.2.2. This method is dependent on the type 
and geometry of the structure, as well as the location of the girder (i.e. interior or exterior). Article 4.6.2.2 specifies the exact parameter ranges for span length, girder spacing, slab thickness and number of girders.

\subsubsection{Interior Girder Distribution Factors}

Interior girder distribution factors for moment and shear could be found from Specification Tables 4.6.2.2.2b-1 and 4.6.2.2.3a-1, respectively. Therefore, the distribution factor for moment for an interior girder (one and two lanes loaded respectively) is the following:

$$
\begin{aligned}
& \mathrm{DF}_{\text {moment-one lane loaded }}=0.06+\left(\frac{\mathrm{S}}{14}\right)^{0.4}\left(\frac{\mathrm{S}}{\mathrm{L}}\right)^{0.3}\left(\frac{\mathrm{K}_{\mathrm{g}}}{12.0 \mathrm{Lt}_{\mathrm{s}}{ }^{3}}\right)^{0.1} \\
& \mathrm{DF}_{\text {moment-two lanes loaded }}=0.075+\left(\frac{\mathrm{S}}{9.5}\right)^{0.6}\left(\frac{\mathrm{S}}{\mathrm{L}}\right)^{0.2}\left(\frac{\mathrm{K}_{\mathrm{g}}}{12.0 \mathrm{Lt}_{\mathrm{s}}{ }^{3}}\right)^{0.1}
\end{aligned}
$$

The distribution factors for an interior girder for shear (one and two lanes loaded respectively) are the following:

$$
\mathrm{DF}_{\text {shear-one loaded }}=0.36+\left(\frac{\mathrm{S}}{25.0}\right)
$$




$$
\mathrm{DF}_{\text {shear-two lanes loaded }}=0.2+\left(\frac{\mathrm{S}}{12}\right)-\left(\frac{\mathrm{S}}{35}\right)^{2.0}
$$

$$
\text { where: } \quad \begin{array}{ll}
\mathrm{S} & =\text { girder spacing }(\mathrm{ft}) \\
\mathrm{L} & =\text { span length }(\mathrm{ft}) \\
\mathrm{K}_{\mathrm{g}} & =\text { longitudinal stiffness parameter } \\
\mathrm{t}_{\mathrm{s}} & =\text { depth of concrete slab (in) }
\end{array}
$$

These approximate equations have the following applicability limits:

- $3.5 \leq \mathrm{S} \leq 16.0$

- $4.5 \leq \mathrm{t}_{\mathrm{s}} \leq 12.0$

- $20 \leq \mathrm{L} \leq 240$

- $\mathrm{N}_{\mathrm{b}} \leq 4$

- $10,000 \leq \mathrm{K}_{\mathrm{g}} \leq 7,000,000$

where: $\quad \mathrm{N}_{\mathrm{b}} \quad=$ number of girders

\subsubsection{Exterior Girder Distribution Factors}

For an exterior girder, the live load distribution factors for moment and shear are described from Specification Tables 4.6.2.2.2d-1 and 4.6.2.2.3b-1, respectively. The exterior girder distribution factor for moment with one lane loaded is computed using the 
lever rule. The lever rule assumes that the deck is simply supported with hinges at the center lines of the respected girder. Multiple presence factor, described in section 3.4.2, is to be applied to distribution factor computed from the lever rule. To calculate the distribution factor for two or more lanes loaded, the governing interior distribution factor has to be multiplied by the following correction factor:

$$
e=0.77+\frac{d_{e}}{9.1}
$$

where: $\quad d_{e}=$ the distance between the web of the exterior beam and the interior edge of curb or traffic barrier (ft)

For slab on steel bridges with cross frames or diaphragms a special analysis should also be considered (Article 4.6.2.2.2d). This approximate method assumes that the slab deflects and rotates as a rigid cross section. Likewise in the lever rule, following the computation of the distribution factor for a single lane and two or more lanes loaded, the multiple presence factors has to be applied. The procedure is outlined below:

$$
\mathrm{R}=\frac{\mathrm{N}_{\mathrm{L}}}{\mathrm{N}_{\mathrm{b}}}+\frac{\mathrm{X}_{\mathrm{ext}} \sum \mathrm{N}_{\mathrm{L}} \mathrm{e}}{\sum \mathrm{x}^{2}}
$$

where: $\mathrm{R} \quad=$ reaction on exterior beam in terms of lanes

$$
\mathrm{N}_{\mathrm{L}} \quad=\text { number of loaded lanes under consideration }
$$




$$
\begin{aligned}
& \text { e } \quad \text { eccentricity of a design truck or a design lane load from the } \\
& \text { center of gravity of the pattern of girders (ft.) } \\
& \quad=\text { horizontal distance from the center of gravity of the pattern of } \\
& \quad \text { girders to each girder (ft.) } \\
& \mathrm{X}_{\mathrm{ext}} \quad \text { = horizontal distance from the center of gravity of the pattern of } \\
& \quad \text { girders to the exterior girder (ft.) } \\
& \mathrm{N}_{\mathrm{b}} \quad \text { = number of beams or girders }
\end{aligned}
$$

\subsubsection{Fatigue Distribution Factors}

The distribution factor for fatigue is computed according to Specifications Article 3.6.1.4.3b. It is calculated for only one lane loaded and no multiple presence factor applied. Hence, it could be computed by taking the governing exterior distribution factor and divide it by the multiple presence factor.

\subsubsection{Live-Load Distribution Factors}

When computing the live load deflection factor, all design lanes shall be loaded and all the girders are assumed to deflect equally (Article 2.5.2.6.2). Hence, the live load deflection distribution factor is equal to the number of lanes divided by the number of girders. Load combination Service I shall be used with the design truck portion including dynamic allowance and multiple presence factor must also be applied. 


\subsection{Other Force Effects}

\subsubsection{Dynamic Load Allowance}

Dynamic effects to moving vehicles may be attributed to the hammering effect, which is the dynamic response of the wheel assembly to riding surface imperfections, such as deck joints, potholes and cracks. Also, dynamic response of the bridge as a system to passing vehicles due to surface roughness could be a cause of dynamic behavior. Research shows that among highway bridges, the dynamic response of a bridge system is approximately $25 \%$ of the static response. The dynamic load allowance account for those responses, as it is described in Article 3.6.2. It defined to be $15 \%$ for fatigue limit state evaluation, and 33\% for all other limit state (Table 3.6.2.1-1).

\subsubsection{Multiple Presence Factor}

The multiple presence factor account for the possibility of more than one lane loaded when calculating live-load distribution factors as defined in Article 3.6.1.1.2. Specifications note that the multiple presence factors are not to be used when computing fatigue limit state and when using the approximate equations from tables 4.6.2.2.2, since it is already incorporated in them. Hence, the multiple presence factors are to be used when distribution factors are computed using the lever rule, and the special analysis methods. 


\subsubsection{Effective Width}

Longitudinal stresses in the flanges are spread across the flange and in the composite deck by in-plane shear stresses. Therefore, the longitudinal stresses are not uniform. The effective width is a reduced flange width where the longitudinal stresses can be assumed uniformly distributed. Hence, the resulting force is the same as in the non uniform stress distribution. Calculation of the effective width is dependent on several parameters, such as span length, top flange width, slab thickness, girder spacing, web thickness and the location of the girder (Interior or Exterior) and is described in Article 4.6.2.6.1. Interior girder effective width is computed as follows:

- One quarter of the effective span length

- 12.0 times the average depth of the slab, plus the greater of web thickness or one-half the width of the top flange of the girder, or

- The average spacing of adjacent beams

For an exterior girder, the effective width is one half of the effective width of the adjacent interior beam plus the minimum of the least of:

- One-eighth of the effective span length,

- 6.0 times the average depth of the slab, plus the greater of half the web thickness or one-quarter of the width of the top flange of the girder, or 
- The width of the overhang

\subsubsection{Load Modifier}

Ductility, redundancy, and operational importance are significant aspects affecting the margin of safety of bridges (Article C1.3.2.1): The ductility and redundancy factors are directly related to the strength of the structure, and the operational importance factor addresses the consequence of the bridge being out of service: For the strength limit state and extreme event limits states load factors are shown in Table 3.4.1-2 of the specification; the factors for all other limit states are to be taken as 1.00 . the limits of the load modifier, which is the product of the ductility, redundancy, and operational importance factors, is described in Article 1.3.2.1 of the specifications as the following:

For load for which the maximum value of $\gamma_{i}$ is appropriate:

$$
\eta_{\mathrm{i}}=\eta_{\mathrm{D}} \eta_{\mathrm{R}} \eta_{\mathrm{I}} \geq 0.095
$$

For load for which the minimum value of $y_{i}$ is appropriate:

$$
\eta_{i}=\frac{1}{\eta_{D} \eta_{R} \eta_{I}} \leq 1.0
$$

where: $\eta_{D} \quad=$ a factor relating to ductility as specified in Article 1.3.3 
$\eta_{\mathrm{R}}=\mathrm{a}$ factor relating to redundancy as specified in Article 1.3.4

$\eta_{\mathrm{I}}=\mathrm{a}$ factor relating to operational importance as specified in Article 1.3 .5

\subsection{Load Combinations}

The AASHTO LRFD Bridge Design Specifications define a variety of load combinations to assess the failure limits of the bridge system. The design of a composite steel I-section is defined in Chapter 6 of the Specifications. The proper evaluation of the safety of a steel bridge girder, a variety of limit states must be satisfied; consequently each component and connection has to satisfy for all the limit states the following equation:

$$
\mathbf{Q}=\Sigma \eta_{\mathrm{i}} \gamma_{\mathrm{i}} \mathbf{Q}_{\mathrm{i}} \leq \boldsymbol{\Phi} \mathbf{R}_{\mathrm{n}}=\mathbf{R}_{\mathrm{r}}
$$

$$
\begin{array}{ll}
\text { where } \eta_{\mathrm{i}} & =\text { load modifier specified in Article 1.3.2 } \\
\text { Qi } & =\text { force effects from loads specified herein } \\
\gamma_{\mathrm{i}} & =\text { load factors specified in Tables 3.4.1-1 and 3.4.1-2 } \\
\Phi & =\text { resistance factor } \\
\mathrm{R}_{\mathrm{n}} & =\text { nominal resistance } \\
\mathrm{R}_{\mathrm{r}} & =\text { factored resistance }
\end{array}
$$

There are three basic limit states: strength, service, and fatigue. The strength limit state ensures the design has sufficient strength and stability by assessing the flexural and 
shear capacities of the member during each construction stage and in the final condition. The service limit state controls the stresses and deflections of the structure to verify that the bridge will satisfactorily perform during its service life. The fatigue limit state ensures that the bridge will not experience fatigue cracking or fracture due to cyclic loading. The following is a brief description of the three limit states specified in the bridge design code.

\subsubsection{Strength Limit States}

The strength limit states assess the structures strength and stability of the design structure under design. The following are the strength limit states as described in Article 3.2.1 of the specifications:

Strength I - Basic load combination relating to the normal vehicular use of the bridge without wind.

Strength II - Load combination relating to the use of the bridge by Ownerspecified special design vehicles, evaluation permit vehicles, or both without wind.

Strength III - Load combination relating to the bridge exposed to wind velocity exceeding $55 \mathrm{MPH}$.

Strength IV - Load combination relating to very high dead load to live load force effect ratios. 

Strength V - Load combination relating to normal vehicular use of the bridge with wind of $55 \mathrm{MPH}$ velocity.

Table 3.4.1-1 and 3.4.1-2 discusses the appropriate load factors to be applied and Article 3.4.2 of the specifications defines the load factors to apply when assessing constructability.

\subsubsection{Service Limit States}

The service limit states control the stresses and deflections of the bridge to ensure proper performance during the service life of the bridge. The Live-load Deflection check is at the Service I load level, which applies a load factor of 1.0 to all load types. It is optional and is covered in Article 2.5.2.6.2 of the specifications. The permanent deflections check, which limits the yielding of the section to control the ride ability of the structure, are controlled by the Service II load combination, which applies a factor of 1.3 to the live-load and 1.0 to all other loads.

\subsubsection{Fatigue Limit States}

The fatigue limit state relates to repetitive gravitational vehicular live load and dynamic responses under a single design truck. This limit state ensures fatigue cracking and fracture during cyclic loading throughout the 75-year design life of the structure. The fatigue requirements must be checked when loaded with the fatigue load 
combination specified in Table 3.4.1-1 of the code; this load combination applies a load factor of 0.75 to the fatigue truck with no multiple presence factors.

The following sections detail the process that must be followed for the Third Edition of the specifications to evaluate each limit state.

\subsection{Summary of the Third Edition of the ASHTO LRFD Specifications}

The purpose of the development of the 3rd Edition of the AASHTO Bridge Design Specifications was a step towards a consistent set of specifications for both straight and horizontally-curved steel I-girders. The result is a set of specifications that include vertical bending and lateral flange bending. Straight I-girders experience flange lateral bending as a result of wind loads and torsion, which can be caused by significant skew, construction limit state loading such as overhang brackets, and staggered crossframes.

The $3^{\text {rd }}$ Edition of the AASHTO Bridge Design Specifications also incorporate general section proportion limits to make the initial design easier to develop. Appendix C contains flow-charts to guide the design of steel I-girders, and Appendix D incorporates procedures for determining fundamental values, such as the plastic moment and yield moment. The following section describes the cross-section proportion limits of the specifications followed by strength, service and fatigue limit states design codes. 


\subsubsection{Cross-section Proportion Limits}

The Third Edition of the AASHTO LRFD Bridge Design Specifications describes proportion limits for the web, flanges, and general geometry in Article 6.10.2. It provides an initial design tool to prevent excessive deformations during welding, allows for easier proportioning of the web, and to prevent difficulties with handling during construction. Overall, it is a good initial measure for the final girder section.

\subsubsection{Web Proportions}

To prevent the design of girders that are difficult to handle during the construction stage, and to set the upper limit on the slenderness of webs without longitudinal stiffeners are limited to the following:

$$
\frac{\mathrm{D}}{\mathrm{t}_{\mathrm{w}}} \leq 150
$$

\subsubsection{Flange Proportions}

The following is a list of compression and tension flange proportions as described in Article 6.10.2.2 of the specifications.

$$
\text { - } \frac{b_{f}}{2 t_{f}} \leq 12.0
$$


- $b_{\mathrm{f}} \geq \mathrm{D} / 6$

- $\mathrm{t}_{\mathrm{f}} \geq 1.1 \mathrm{t}_{\mathrm{w}}$

- $0.1 \leq \frac{\mathrm{I}_{\mathrm{yc}}}{\mathrm{I}_{\mathrm{yt}}} \leq 10$

where: $\mathrm{I}_{\mathrm{yc}} \quad=$ moment of inertia of the compression flange of the steel section about the vertical axis in the plane of the web $\left(\mathrm{in}^{4}\right)$

$\mathrm{I}_{\mathrm{yt}} \quad=$ moment of inertia of the tension flange of the steel section about the vertical axis in the plane of the web $\left(\mathrm{in}^{4}\right)$

The flange slenderness, Equation 6.10.2.2-1, is an upper limit, set at 12.0 to ensure that the flange will not excessively distort when welded to the web. White and Barth (1998) observed that the cross-section aspect ratio, $\mathrm{D} / \mathrm{b}_{\mathrm{f}}$ is a significant parameter affecting the strength and moment-rotation characteristics of I-sections. Equation 6.10.2.2-2 limits the cross-section aspect ratio to 6 to make certain that the section can develop post buckling shear resistance due to tension-field action, discussed in C6.10.2.2 of the specifications. Equation 6.10.2.2-3 ensures that some restraint will be provided by the against web shear buckling and also that the boundary conditions assumed at the web-flange juncture in the web bend-buckling and compression flange local buckling formulations within these specifications are sufficiently accurate (Article C6.10.2.2). In Equation 6.10.2.2-4, limiting the ratio of $\mathrm{I}_{\mathrm{yc}}$ to $\mathrm{I}_{\mathrm{yt}}$ prevents the section from being difficult to handle during construction and provides more proportioned sections. 


\subsection{Limit State Specifications}

The following sections details the design specifications of the Third Edition of the AASHTO Bridge Design Code for the three major load conditions, Strength, Service and Fatigue limit states.

\subsubsection{Strength Limit State}

As previously mentioned, this study focused on the design of simple span bridge structures, therefore only the positive bending flexural capacity will be described in this section.

\subsubsection{Positive Flexural Capacity}

The Third Edition of the ASHTO LRFD defines the positive flexural resistance of a composite section in Article 6.10.7. It is different whether a section classifies as compact or non-compact, but regardless of the girder classification, it has to satisfy the ductility requirement in Article 6.10.7.3, which is the following:

$$
\mathrm{D}_{\mathrm{p}} \leq 0.42 \mathrm{D}_{\mathrm{t}}
$$

where $D_{p}=$ distance from the top of the concrete deck to the neutral axis of the composite section at the plastic moment (in.) 


$$
\text { Dt } \quad=\text { total depth of the composite section (in.) }
$$

The ductility requirement specified above is set to protect the concrete deck from premature crushing. The following sections describe the procedure involved in determining the positive flexural resistance of a composite girder for compact and noncompact sections.

\section{Compact Sections}

Article 6.10.7.1.1 of the specifications states that compact sections must satisfy the following criteria:

- $\mathrm{F}_{\mathrm{yf}} \leq 70 \mathrm{ksi}$

- $\frac{\mathrm{D}}{\mathrm{t}_{\mathrm{w}}} \leq 150$, and

$$
\text { - } \frac{2 \mathrm{D}_{\mathrm{cp}}}{\mathrm{t}_{\mathrm{w}}} \leq 3.76 \sqrt{\frac{\mathrm{E}}{\mathrm{F}_{\mathrm{yc}}}}
$$

If the section is deemed compact, the following equation must be satisfied:

$$
\mathrm{M}_{\mathrm{u}}+\frac{1}{3} \mathrm{f}_{1} \mathrm{~S}_{\mathrm{xt}} \leq \phi_{\mathrm{f}} \mathrm{M}_{\mathrm{n}}
$$


where $\mathrm{M}_{\mathrm{u}} \quad$ = bending moment about the major axis of the cross-section determined as specified in Article 6.10.1.6 (k-in)

$\mathrm{f}_{1} \quad=$ flange lateral bending stress $(\mathrm{ksi})$

$\mathrm{S}_{\mathrm{xt}}=$ elastic section modulus about the major axis of the section to the tension flange taken as $\mathrm{M}_{\mathrm{yt}} / \mathrm{F}_{\mathrm{yt}}\left(\mathrm{in}^{3}\right)$

$\varphi_{\mathrm{f}} \quad=1.0$, resistance factor for flexure

$\mathrm{M}_{\mathrm{n}} \quad=$ nominal flexural resistance of the section specified in Article 6.10.7.1.2 (k-in)

For composite sections in positive flexure at strength limit state, lateral bending is not considered since the compression flange is continuously supported by the concrete deck.

The specifications define the nominal flexural resistance, $\mathrm{M}_{\mathrm{n}}$ in Article 6.10.7.1.2, if the distance from the top of the concrete deck to the neutral axis of the composite section at plastic moment, $\mathrm{Dp}$, is less than one tenth of the total depth of the composite section, Dt, then the nominal flexural resistance of the section is equal to the plastic moment of the section. Sections that do not satisfy the previous criteria are limited to the resistance calculated from Eq. 6.10.7.1.2-2, which limits the nominal resistance to prevent premature crushing of the concrete deck and ensures sufficient ductility.

$$
M_{n}=M_{p}\left(1.07-0.7 \frac{D_{p}}{D_{t}}\right)
$$




\section{Non-compact Sections}

Non-compact sections are limited to the moment at first yield, and must satisfy the following inequalities:

$$
\begin{aligned}
& \text { Compression flange: } \quad \mathrm{f}_{\mathrm{bu}} \leq \phi_{\mathrm{f}} \mathrm{F}_{\mathrm{nc}} \\
& \text { where } \mathrm{f}_{\mathrm{bu}} \quad=\text { flange stress calculated without consideration of flange lateral } \\
& \quad \text { bending determined as specified in Article 6.10.1.6 (ksi) } \\
& \quad \begin{aligned}
\mathrm{F}_{\mathrm{nc}} \quad & \text { nominal flexural resistance of the compression flange determined } \\
& \text { as specified in Article 6.10.7.2.2 (ksi) } \\
\varphi_{\mathrm{f}} & =\text { resistance factor for flexure specified in Article 6.5.4.2 }
\end{aligned}
\end{aligned}
$$

$$
\begin{aligned}
& \text { Tension flange: } \quad \mathrm{f}_{\mathrm{bu}}+\frac{1}{3} \mathrm{f}_{1} \leq \phi_{\mathrm{f}} \mathrm{F}_{\mathrm{nt}} \\
& \text { where: } \mathrm{F}_{\mathrm{nt}} \quad \text { nominal flexural resistance of the tension flange determined as } \\
& \quad \text { specified in Article 6.10.7.2.2 (ksi) } \\
& \quad=\text { flange lateral bending stress determined as specified in Article } \\
& \quad 6.10 .1 .6(\mathrm{ksi})
\end{aligned}
$$


For composite section in positive flexure, lateral bending does not need to be considered in the compression flange at the strength limit state, because the flange is continuously supported by the concrete deck. The nominal flexural resistance of a noncompact section is limited to the moment at first yield and has to be calculated for each flange. The compression flange nominal flexural strength is computed from the following equation:

$$
F_{n c}=R_{b} R_{h} F_{y c}
$$

where $\mathrm{R}_{\mathrm{b}} \quad$ = web load-shedding factor determined as specified in Article

$$
6.10 .1 \cdot 10.2
$$

$\mathrm{R}_{\mathrm{h}} \quad=$ hybrid factor determined as specified in Article 6.10.1.10.1

The hybrid factor is 1.0 for homogeneous sections, rolled beams and sections with higher strength steel in the web than in both flanges. Otherwise, the hybrid factor can be determined using the following equations:

$$
\begin{aligned}
& \mathrm{R}_{\mathrm{h}}=\frac{12+\beta\left(3 \rho-\rho^{3}\right)}{12+2 \beta} \\
& \beta=\frac{2 \mathrm{D}_{\mathrm{n}} \mathrm{t}_{\mathrm{w}}}{\mathrm{A}_{\mathrm{fn}}} \\
& \text { where } \rho \quad=\text { minimum of } \mathrm{F}_{\mathrm{yw}} / \mathrm{f}_{\mathrm{n}} \text { and } 1.0
\end{aligned}
$$


$\mathrm{A}_{\mathrm{fn}} \quad=$ sum of the flange area on the side of the neutral axis corresponding to $\mathrm{D}_{\mathrm{n}}($ in.2)

$\mathrm{D}_{\mathrm{n}} \quad=$ larger of the distances from the elastic neutral axis of the cross section to the inside face of either flange (in.)

$\mathrm{f}_{\mathrm{n}} \quad=$ for sections where yielding occurs first in the flange on the side of the neutral axis corresponding to $D_{n}$, the largest of the specified minimum yield strengths of each component included in the calculation of $\mathrm{A}_{\mathrm{fn}}$ (ksi). Otherwise the largest of the elastic stresses in the flange on the side if the neutral axis corresponding to $D_{n}$ at first yield on the opposite side of the neutral axis

The Web Load-shedding factor, $\mathrm{R}_{\mathrm{b}}$ is defined in Article 6.10.1.10.2 and is taken as 1.0 when:

- checking constructability according to the provisions of Article 6.10.3.2

- if the section is composite, in positive flexure, and the web satisfies the requirement of Article 6.10.2.1.1 or,

- one or more longitudinal stiffeners are provided and

$$
\frac{\mathrm{D}}{\mathrm{t}_{\mathrm{w}}} \leq 0.95 \sqrt{\frac{\mathrm{Ek}}{\mathrm{F}_{\mathrm{yc}}}}
$$

- the web satisfies:

$$
\frac{2 D_{c}}{t_{w}} \leq \lambda_{r w}
$$


where $\lambda_{\mathrm{rw}}=$ limiting slenderness ratio for a non-compact web

$$
\lambda_{\mathrm{rw}}=5.7 \sqrt{\frac{\mathrm{E}}{\mathrm{F}_{\mathrm{yc}}}}
$$

Otherwise $R_{b}$ is calculated using the following equation:

$$
\mathrm{R}_{\mathrm{b}}=1-\left(\frac{\mathrm{a}_{\mathrm{wc}}}{1200+300 \mathrm{a}_{\mathrm{wc}}}\right)\left(\frac{2 \mathrm{D}_{\mathrm{c}}}{\mathrm{t}_{\mathrm{w}}}-\lambda_{\mathrm{rw}}\right) \leq 1.0
$$

$$
\begin{aligned}
& \text { where } \mathrm{a}_{\mathrm{wc}} \quad \text { for composite longitudinally-stiffened sections in positive } \\
& \text { flexure }
\end{aligned}
$$

$$
a_{w c}=\frac{2 D_{c} t_{w}}{b_{f c} t_{f c}+b_{s} t_{s}\left(1-f_{D C 1} / F_{y c}\right) / 3 n}
$$

where $\mathrm{f}_{\mathrm{DC} 1}=$ compression flange stress in the section under consideration, calculated without consideration of flange lateral bending and caused by the factored permanent load applied before the concrete deck has hardened or is made composite (ksi) $\mathrm{D}_{\mathrm{c}} \quad=$ depth of web in compression in elastic range (in.) 
otherwise

$$
a_{w c}=\frac{2 D_{c} t_{w}}{b_{f c} t_{f c}}
$$

\subsubsection{Shear}

The shear resistance of a section in Strength Limit State for stiffened, unstiffened web is discussed in Article 6.10.9 of the Third Edition of the AASHTO LRFD. The consideration of tension field action (Basler 1961) is not permitted for unstiffened webs panels. Hence, the nominal shear resistance is controlled by either the ratio of shearbuckling resistance to the shear yield strength, or by the shear-buckling coefficient as calculated in the following:

$$
\begin{aligned}
& \mathrm{V}_{\mathrm{n}}=\mathrm{V}_{\mathrm{cr}}=\mathrm{C} \mathrm{V}_{\mathrm{p}} \\
& \text { and } \quad \mathrm{V}_{\mathrm{p}}=0.58 \mathrm{~F}_{\mathrm{wy}} \mathrm{Dt}_{\mathrm{w}} \\
& \text { where } \mathrm{V}_{\mathrm{n}} \quad=\text { nominal shear resistance (kip) } \\
& \mathrm{V}_{\mathrm{cr}} \quad=\text { shear buckling resistance (kip) } \\
& \mathrm{V}_{\mathrm{p}} \quad=\text { plastic shear force (kip) } \\
& \mathrm{C}=\text { ratio of the shear buckling resistance to the shear yield strength } \\
& \text { determined as specified in Article 6.10.9.3.2, with the shear } \\
& \text { buckling coefficient, } \mathrm{k} \text {, taken equal to } 5.0 \\
& \mathrm{~F}_{\mathrm{yw}}=\text { minimum yield strength of the web (ksi) }
\end{aligned}
$$




$$
\begin{aligned}
& \mathrm{D} \quad=\text { depth of the web (in.) } \\
& \mathrm{t}_{\mathrm{w}} \quad=\text { thickness of web (in.) }
\end{aligned}
$$

The coefficient $\mathrm{C}$ can be determined by the following method described in Article 6.10.9.3.2, and is as follows:

$$
\begin{gathered}
\text { - If } \frac{\mathrm{D}}{\mathrm{t}_{\mathrm{w}}} \leq 1.12 \sqrt{\frac{\mathrm{Ek}}{\mathrm{F}_{\mathrm{yw}}}}, \text { then } \\
\mathrm{C}=1.0
\end{gathered}
$$

- If $\quad 1.12 \sqrt{\frac{\mathrm{Ek}}{\mathrm{F}_{\mathrm{yw}}}}<\frac{\mathrm{D}}{\mathrm{t}_{\mathrm{w}}} \leq 1.40 \sqrt{\frac{\mathrm{Ek}}{\mathrm{F}_{\mathrm{yw}}}}$, then

$$
\mathrm{C}=\frac{1.12}{\frac{\mathrm{D}}{\mathrm{t}_{\mathrm{w}}}} \sqrt{\frac{\mathrm{Ek}}{\mathrm{F}_{\mathrm{yw}}}}
$$

- If $\frac{\mathrm{D}}{\mathrm{t}_{\mathrm{w}}}>1.40 \sqrt{\frac{\mathrm{Ek}}{\mathrm{F}_{\mathrm{yw}}}}$, then

$$
C=\frac{1.57}{\left(\frac{D}{t_{w}}\right)^{2}}\left(\frac{E k}{F_{y w}}\right)
$$


where $\mathrm{k}=$ shear buckling coefficient, which is 5.0 for unstiffened webs, or for stiffened webs is as follows:

$$
\mathrm{k}=5+\frac{5}{\left(\frac{\mathrm{d}_{0}}{\mathrm{D}}\right)^{2}}
$$

where $\mathrm{d}_{0} \quad=$ transverse stiffener spacing

Nominal resistance of stiffened web section is described in Article 6.10.9.3 of the Specifications and is defined based on the section location (Interior and end panels). When stiffened interior web panels of homogeneous and hybrid girders are proportioned according to Eq. 6.10.9.3.2-1, they are capable of developing post-buckling shear resistance due to tension-field action (White 2004).

$$
\frac{2 \mathrm{Dt}_{\mathrm{w}}}{\left(\mathrm{b}_{\mathrm{fc}} \mathrm{t}_{\mathrm{fc}}+\mathrm{b}_{\mathrm{ft}} \mathrm{t}_{\mathrm{ft}}\right)} \leq 2.5
$$

The nominal shear resistance of these panels can be computed by summing the contributions of beam action and post-buckling tension-field action, and it is defined as follows: 


$$
\mathrm{V}_{\mathrm{n}}=\mathrm{V}_{\mathrm{p}}\left[\mathrm{C}+\frac{0.87(1-\mathrm{C})}{\sqrt{1+\left(\frac{\mathrm{d}_{0}}{\mathrm{D}}\right)^{2}}}\right]
$$

in which: $\quad \mathrm{V}_{\mathrm{p}}=0.58 \mathrm{~F}_{\mathrm{yw}} \mathrm{D} \mathrm{t}_{\mathrm{w}}$

$$
\begin{aligned}
& \text { where } \begin{array}{ll}
\mathrm{d}_{0} & =\text { transverse stiffener spacing (in) } \\
\mathrm{V}_{\mathrm{n}} & =\text { nominal shear resistance of a web panel (kips) } \\
\mathrm{V}_{\mathrm{p}} & =\text { plastic shear force (kips) } \\
\mathrm{C} & =\text { ratio of the shear-buckling resistance to the shear yield strength } \\
& \text { (described previously) }
\end{array}
\end{aligned}
$$

If the total area of the flanges within the panel is small relative to the area of the web, the post-buckling resistance cannot develop (White 2004). Therefore, the shear resistance can be computed according to the following:

$$
\mathrm{V}_{\mathrm{n}}=\mathrm{V}_{\mathrm{p}}\left[\mathrm{C}+\frac{0.87(1-\mathrm{C})}{\sqrt{1+\left(\frac{\mathrm{d}_{0}}{\mathrm{D}}\right)^{2}}+\frac{\mathrm{d}_{0}}{\mathrm{D}}}\right]
$$

The shear in end panels adjacent to simple supports is limited to either the shear yielding or the shear-buckling resistance. Therefore, the nominal shear resistance of web end 
panels shall be calculated according to article 6.10.9.3.3 of the Specifications, and is as follows:

$$
\begin{aligned}
& \mathrm{V}_{\mathrm{n}}=\mathrm{V}_{\mathrm{cr}}=\mathrm{C} \mathrm{V}_{\mathrm{p}} \text {, and } \\
& \mathrm{V}_{\mathrm{p}}=0.58 \mathrm{~F}_{\mathrm{yw}} \mathrm{D} \mathrm{t}_{\mathrm{w}}
\end{aligned}
$$

The transverse stiffener spacing of end panels shall not exceed 1.5D.

\subsubsection{Constructability}

The Third Edition of the AASHTO Specifications defines checks for constructability in section 6.10.3. During each construction stage, the member must satisfy requirements for flange nominal yielding, flexural resistance, and web bend buckling, equations 6.10.3.2.1-1, 6.10.3.2.1-2, and 6.10.3.2.1-3 respectively. The first equation is a yielding limit state check, ensures that the maximum combined stress in the compression flange will not exceed the minimum specified yield strength of the flange. Equation 2 ensures that the member has sufficient strength towards lateral torsional and flange local buckling based limit states. The third check ensures, that theoretical web bend-buckling will not occur during construction.

$$
\mathrm{f}_{\mathrm{bu}}+\mathrm{f}_{1} \leq \phi_{\mathrm{f}} \mathrm{R}_{\mathrm{h}} \mathrm{F}_{\mathrm{yc}}
$$




$$
\begin{aligned}
& \mathrm{f}_{\mathrm{bu}}+\frac{1}{3} \mathrm{f}_{1} \leq \phi_{\mathrm{f}} \mathrm{F}_{\mathrm{nc}} \\
& \mathrm{f}_{\mathrm{bu}} \leq \phi_{\mathrm{f}} \mathrm{F}_{\mathrm{crw}}
\end{aligned}
$$

where $\varphi_{\mathrm{f}} \quad=$ resistance factor for flexure specified in Article 6.5.4.2

$\mathrm{f}_{\mathrm{bu}} \quad=$ flange stress calculated without consideration of flange lateral bending determined as specified in Article 6.10.1.6 (ksi)

$\mathrm{f}_{1}=$ flange lateral bending stress determined as specified in Article $6.10 .1 .6(\mathrm{ksi})$

$\mathrm{F}_{\mathrm{crw}}=$ nominal elastic bend-buckling resistance determined as specified in Article 6.10.1.9 (ksi)

$\mathrm{F}_{\mathrm{nc}} \quad=$ nominal flexural resistance of the flange and shall be determined according to Article 6.10.8.2. (ksi) For sections in straight i-girder bridges, $F_{n c}$ can be taken as $\mathrm{M}_{n \mathrm{nc}} / \mathrm{S}_{\mathrm{xc}}$. In coputing $\mathrm{F}_{\mathrm{nc}}$ for constructability, $\mathrm{R}_{\mathrm{b}}$ shall be taken as 1 .

$\mathrm{M}_{\mathrm{yc}} \quad$ = yield moment with respect to the compression flange determined as specified in Article D6.2 (kip-in)

$\mathrm{S}_{\mathrm{xc}}=$ elastic section modulus about the major axis of the section to the compression flange, shall be taken as $\mathrm{M}_{\mathrm{yc}} / \mathrm{F}_{\mathrm{yc}}\left(\mathrm{in}^{3}\right)$

$\mathrm{R}_{\mathrm{h}} \quad=$ hybrid factor specified in Article 6.10.1.10.1

The Third Edition of the specifications makes a distinction between discretely and continuously braced cross sections, and requires the consideration of the flange lateral 
bending stresses, $\mathrm{f}_{\mathrm{l}}$, which is the result of overhang bracket forces and wind loads. For a continuously braced flange, flange lateral bending need not to be considered. For members with slender webs, when $f_{1}$ is zero, equation 6.10.3.2.1-1 needs not to be checked while for sections with compact or non-compact webs; equation 6.10.3.2.1-3 shall not be checked. Equation 1 often controls over equation 2, especially for members with large $f_{1}$ and for compact and non-compact webs. However, for sections with noncompact flanges or large unsupported lengths during constructions combined with small or zero values for $\mathrm{f}_{1}$, equation 2 typically controls. The specifications state in Article 6.10.3.2.2 the following flange nominal yielding requirement for a discretely braced tension flange must be satisfied:

$$
\mathrm{f}_{\mathrm{bu}}+\mathrm{f}_{1} \leq \phi_{\mathrm{f}} \mathrm{R}_{\mathrm{h}} \mathrm{F}_{\mathrm{yt}}
$$

where $\mathrm{F}_{\mathrm{yt}} \quad=$ minimum specified yield strength of the tension flange (ksi)

It ensures that during each construction stage, the stress in the flange will not exceed the minimum required yield strength times the hybrid factor under factored loads. For continuously braced compression and tension flanges the following equation must be satisfied:

$$
\mathrm{f}_{\mathrm{bu}} \leq \phi_{\mathrm{f}} \mathrm{R}_{\mathrm{h}} \mathrm{F}_{\mathrm{yt}}
$$




\subsubsection{Serviceability}

\subsubsection{Elastic Deformations}

The live load deflection criterion is specified in Article 2.5.2.6 together with the criteria for span-to-depth ratio. The designer must determine the maximum deflection based on parameters defined in Section 3.6.1. The outcome of a line girder analysis, multiplied by the lateral distribution factors has to be considered in the absence of a refined analysis to determine the estimated live-load deflection. The limit is $\mathrm{L} / 1000$ if pedestrian traffic is expected on the bridge; otherwise it is $\mathrm{L} / 800$.

\subsubsection{Plastic Deformations}

To evaluate plastic deformations, the Specifications define to use Service II load combinations. Article 6.10.4.2.2 of the specifications determines the allowable stresses the flanges can experience, and is as described below:

For the top flange of composite sections:

$$
\mathrm{f}_{\mathrm{f}} \leq 0.95 \mathrm{R}_{\mathrm{h}} \mathrm{F}_{\mathrm{yf}}
$$

For the bottom flange of composite sections:

$$
\mathrm{f}_{\mathrm{f}}+\frac{\mathrm{f}_{1}}{2} \leq 0.95 \mathrm{R}_{\mathrm{h}} \mathrm{F}_{\mathrm{yf}}
$$


For both steel flanges of non-composite sections:

$$
\mathrm{f}_{\mathrm{f}}+\frac{\mathrm{f}_{1}}{2} \leq 0.80 \mathrm{R}_{\mathrm{h}} \mathrm{F}_{\mathrm{yf}}
$$

where $\mathrm{f}_{\mathrm{f}} \quad=$ flange stress in the section under consideration due to the Service II loads calculated without consideration of flange lateral bending (ksi)

$\mathrm{f}_{\mathrm{l}}=$ flange lateral bending stress in the section under consideration due to the Service II loads determined as specified in Article 6.10.1.6 (ksi)

$\mathrm{R}_{\mathrm{h}} \quad=$ hybrid factor determined as specified in Article 6.10.1.10.1

Above mentioned equations intend to prevent objectionable permanent deflections that would impair ride ability due to heavy traffic loading conditions. These checks also address the increase in flange stresses caused by early web yielding in hybrid sections by including the hybrid factor, $R_{h}$. It is recommended to conservatively apply the value of $R_{h}$ used in Strength limit state checks for these equations as well (Article C6.10.4.2.2).

\subsubsection{Web Requirements}

Article 6.10.4.2.2 of the Third Edition states that sections must satisfy the web requirement check, Eq. 6.10.4.2.2-4, unless the section is composite, in positive flexure, 
and the web satisfies the requirement of Article 6.10.2.1.1, which is the ratio of $\mathrm{D} / \mathrm{t}_{\mathrm{w}}$ less than or equal to 150 .

$$
\mathrm{f}_{\mathrm{c}} \leq \mathrm{F}_{\mathrm{crw}}
$$

$$
\begin{gathered}
\text { where } \mathrm{f}_{\mathrm{c}} \quad=\text { compression-flange stress in the section under consideration due } \\
\text { to the Service II loads calculated without consideration of flange } \\
\quad \text { lateral bending }(\mathrm{ksi}) \\
\mathrm{F}_{\mathrm{crw}} \quad=\text { nominal bend-buckling resistance of web with or without } \\
\\
\text { longitudinal stiffeners specified in Article } 6.10 .1 .9
\end{gathered}
$$

Since this study is focused on simple span composite I-girder designs, this web requirement check is automatically satisfied.

\subsubsection{Fatigue and Fracture Limit State}

The fatigue limit state imposes restrictions on the stress levels under regular conditions to prevent crack growth and fracture during the design life of the bridge. There are two main types of fatigue problems that the specifications require to checks, distortion induced fatigue and load-induced fatigue. 


\subsubsection{Distortion-Induced Fatigue}

Distortion-induced fatigue is discussed in Article 6.6.1.3 of the Third Edition. To prevent distortion-induced fatigue, both the tension and compression flanges of the girder are to be welded or bolted to all transverse connection plate details in order to provide load paths sufficient to transmit forces.

To control web buckling and elastic flexing of the web, the provisions of Article 6.10.5.3 shall be satisfied. Interior web panels with transverse stiffeners, with or without longitudinal stiffeners shall satisfy the following equation:

$$
\mathrm{V}_{\mathrm{u}} \leq \mathrm{V}_{\mathrm{cr}}
$$

$$
\begin{aligned}
& \text { where } \mathrm{V}_{\mathrm{u}} \quad \text { shear in the web in the section under consideration due to } \\
& \text { the un-factored permanent load plus the factored fatigue } \\
& \text { load (kip) } \\
& \mathrm{V}_{\mathrm{cr}} \quad \text { shear-buckling resistance determined from equation } \\
& 6.10 .9 .3 .3-1 \text { (kip) }
\end{aligned}
$$

The factored fatigue load shall be taken as twice that calculated using the Fatigue load combination. 


\subsubsection{Load-Induced Fatigue}

The force effect considered for the fatigue design of steel bridge detail shall be the live load stress range, therefore, residual stresses should not be considered when investigating fatigue. These provisions only apply to details subjected to net tensile stresses. Where un-factored permanent loads induce compression, fatigue should only be investigated if the compressive stress is less then twice the maximum tensile live-load stress resulting from the fatigue load combination. Load induced fatigue detail category shall be determined from Tables 6.6.1.2.3-1 and 6.6.1.2.3-2 in Article 6.6.1.2.3 of the specifications. The detail with the least fatigue resistance employed in typical bridge systems is the welded connection of the cross-frame to the web of the girder, which falls under a fatigue category C'. For load induced fatigue considerations, each detail shall satisfy:

$$
\gamma(\Delta \mathrm{f}) \leq(\Delta \mathrm{F})_{\mathrm{n}}
$$

where $\gamma \quad=$ load factor specified in Table 3.4.1-1 for the fatigue load combination

$(\Delta \mathrm{f}) \quad=$ force effect, live load stress range due to the passage of the fatigue load as specified in Article 3.6.1.4 (ksi)

$(\Delta \mathrm{F})_{\mathrm{n}}=$ nominal fatigue resistance as specified in Article 6.6.1.2.5 (ksi)

The nominal fatigue resistance shall be taken as follows: 


$$
(\Delta \mathrm{F})_{\mathrm{n}}=\left(\frac{\mathrm{A}}{\mathrm{N}}\right)^{\frac{1}{3}} \geq \frac{1}{2}(\Delta \mathrm{F})_{\mathrm{TH}}
$$

in which:

$$
\mathrm{N}=(365)(75) \mathrm{n}(\mathrm{ADTT})_{\mathrm{SL}}
$$

$$
\begin{aligned}
& \text { where A = constant from Table 6.6.1.2.5-1 (ksi3) } \\
& \mathrm{n} \quad=\text { number of stress range cycles per truck passage taken } \\
& \text { from Table 6.6.1.2.5-2 } \\
& (\mathrm{ADTT})_{\mathrm{SL}} \quad=\text { single-lane ADTT as specified in Article 3.6.1.4 } \\
& (\Delta \mathrm{F})_{\mathrm{TH}} \quad=\text { constant-amplitude fatigue threshold taken from Table } \\
& \text { 6.6.1.2.5-3 (ksi) }
\end{aligned}
$$

When the design stress range is less than one half of the constant amplitude fatigue threshold, the detail will theoretically provide infinite life.

\subsubsection{Fracture}

To prevent fracture, the material for main components subjected to tension due to the Strength I load combination are to meet the Charpy V-notch fracture toughness requirements for the appropriate temperature zone, see Article 6.6.2. These requirements vary, based on type of steel, type of construction and the applicable minimum service 
temperature, which could be determined from Table 6.6.2.1. In addition, any member that is fracture critical should be denoted in the plans.

\subsection{Additional Considerations}

This chapter has described the Third Editions of the AASHTO LRFD for the design of steel I-girders considering the strength, service, and fatigue limit states, as well as the general proportions limits. A complete superstructure design requires additional design details to be performed that are outside of the scope of this study. Such details include, shear studs, transverse and bearing stiffeners, bearings, cross frame details, and deck design. 
Table 3.1 Code Equation legend

\begin{tabular}{|c|c|}
\hline Thesis Equation & AASHTO Equation \\
\hline 3.1 & $1.3 .2 .1-2$ \\
\hline 3.2 & $1.3 .2 .1-3$ \\
\hline 3.3 & 1.3.2.1-1 \\
\hline 3.4 & 6.10.2.1.1.-1 \\
\hline 3.5 & $6.10 .2 .2-1$ \\
\hline 3.6 & $6.10 .2 .2-2$ \\
\hline 3.7 & $6.10 .2 .2-3$ \\
\hline 3.8 & $6.10 .2 .2-4$ \\
\hline 3.9 & 6.10.7.3-1 \\
\hline 3.10 & 6.10.7.1.1-1 \\
\hline 3.11 & $6.10 .7 .1 .2-2$ \\
\hline 3.12 & 6.10.7.2.1-1 \\
\hline 3.13 & $6.10 .7 .2 .1-2$ \\
\hline 3.14 & 6.10.7.2.2-1 \\
\hline 3.15 & $6.10 .1 .10 .1-1$ \\
\hline 3.16 & $6.10 .1 .10 .1-2$ \\
\hline 3.17 & $6.10 .1 .10 .2-1$ \\
\hline 3.18 & $6.10 .1 \cdot 10.2-2$ \\
\hline 3.19 & $6.10 .1 .10 .2-4$ \\
\hline 3.20 & $6.10 .1 .10 .2-3$ \\
\hline 3.21 & $6.10 .1 .10 .2-6$ \\
\hline 3.22 & $6.10 .1 .10 .2-5$ \\
\hline 3.23 & $6.10 .9 .2-1$ \\
\hline 3.24 & $6.10 .9 .2-2$ \\
\hline 3.25 & $6.10 .9 \cdot 3.2-4$ \\
\hline 3.26 & 6.10.9.3.2-5 \\
\hline 3.27 & $6.10 .9 .3 .2-6$ \\
\hline 3.28 & 6.10.9.3.2-7 \\
\hline 3.29 & 6.10.9.3.2-1 \\
\hline 3.30 & 6.10.9.3.2-2 \\
\hline 3.31 & $6.10 .9 .3 .2-3$ \\
\hline 3.32 & $6.10 .9 .3 .2-8$ \\
\hline 3.33 & 6.10.9.3.3-1 \\
\hline 3.34 & 6.10.3.2.1-1 \\
\hline 3.35 & 6.10.3.2.1-2 \\
\hline 3.36 & $6.10 .3 .2 .1-3$ \\
\hline 3.37 & 6.10.3.2.2-1 \\
\hline 3.38 & 6.10.3.2.3-1 \\
\hline 3.39 & 6.10.4.2.2-1 \\
\hline 3.40 & $6.10 .4 .2 .2-2$ \\
\hline 3.41 & $6.10 .4 .2 .2-3$ \\
\hline 3.42 & 6.10.4.2.2-4 \\
\hline 3.43 & $6.10 .5 .3-1$ \\
\hline 3.44 & 6.6.1.2.5-1 \\
\hline 3.45 & 6.6.1.2.5-2 \\
\hline
\end{tabular}


Table 3.2 Multiple Presence Factors

\begin{tabular}{|c|c|}
\hline Number of Loaded Lanes & Multiple Presence Factors "m" \\
\hline 1 & 1.20 \\
\hline 2 & 1.00 \\
\hline 3 & 0.85 \\
\hline$>3$ & 0.65 \\
\hline
\end{tabular}

Table 3.3 Dynamic Load Allowance, IM

\begin{tabular}{|l|c|}
\hline Component & IM \\
\hline Deck joints - All Limit States & $75 \%$ \\
\hline $\begin{array}{l}\text { All Other Components } \\
\text { - Fatigue and Fracture Limit } \\
\quad \text { State }\end{array}$ & $15 \%$ \\
$\bullet \quad$ All Other Limit State & $33 \%$ \\
\hline
\end{tabular}

Table 3.4 Load Modifiers

\begin{tabular}{|l|l|}
\hline Ductility & $\eta_{D} \geq 1.05$ \\
\hline Nonductile components and connections & $\eta_{D}=1.00$ \\
\hline Conventional designs and details & $\eta_{D} \geq 0.95$ \\
\hline Components and details with more ductility than required & $\eta_{R} \geq 1.05$ \\
\hline Redundancy & $\eta_{R}=1.00$ \\
\hline Nonredundant members & $\eta_{R} \geq 0.95$ \\
\hline Conventional levels of redundancy & \\
\hline Exceptional levels of redundancy & $\eta_{1} \geq 1.05$ \\
\hline Operational Importance & $\eta_{I}=1.00$ \\
\hline Important bridges & $\eta_{1} \geq 0.95$ \\
\hline Typical bridges & \\
\hline Relatively less important bridges &
\end{tabular}


CLEARANCE AND

LOAD LANE WIOTH
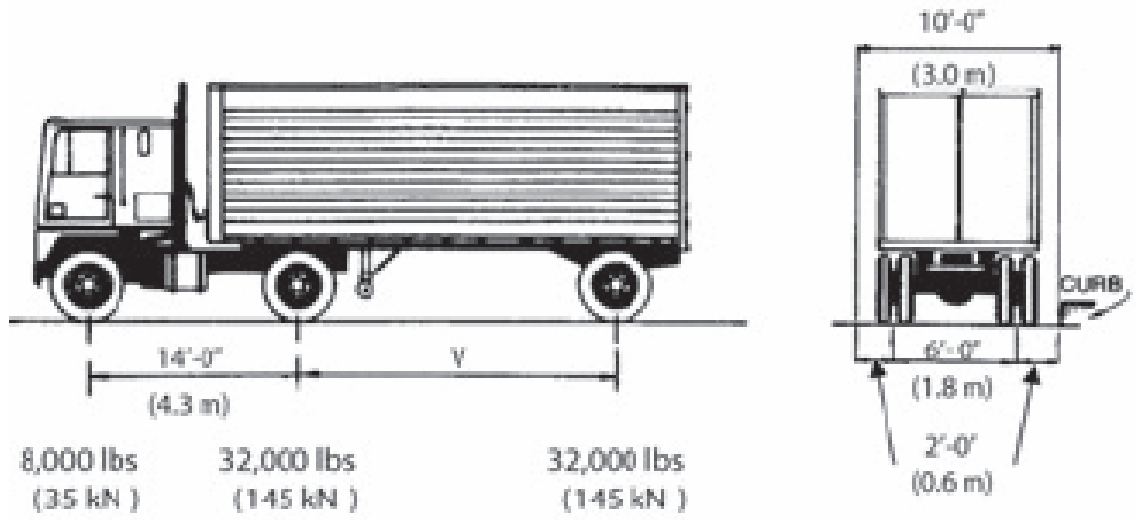

Figure 3.1 AASHTO Design Truck 


\section{Chapter 4}

\section{Optimized Short-Span Steel Bridge Girder Design Study}

\subsection{Introduction}

The purpose of this design study is to develop an optimized simply supported short-span steel girder package for 2 lane cross sections roadway. The following parameters are varied: cross sections (28 ft and $34 \mathrm{ft}$ ), girder configuration (homogeneous and hybrid plate girders, rolled beams), stiffened and un-stiffened webs, girder location (exterior, interior) and span length. The homogeneous plate girders and rolled beams utilize of 50-ksi steel, the hybrid configuration has 50-ksi compression flange and webs, and 70-ksi tension flanges. The designs are completed in accordance with the $3^{\text {rd }}$ Edition of the AASHTO LRFD Bridge Design Specifications (AASHTO 2004).

Previous research (Clingenpeel 2001) has concluded the effect of Live-load Deflection Criteria on the design and economy of plate girders consisting HPS steel. Therefore, this study investigates and compares the designs incorporating the Live-load Deflection Criteria with the ones where it is neglected. 


\subsection{Design Assumptions}

Short-span steel I-girders were designed in accordance with the $3^{\text {rd }}$ Edition of the AASHTO LRFD Bridge Design Specifications (AASHTO 2004). A typical girder elevation is shown in Figure 4.1, where $\mathrm{L}$ is the span length, $\mathrm{C}$ indicates the cross frame spacing, and $\mathrm{X}, \mathrm{Y}$, and $\mathrm{Z}$ denote the transverse stiffener spacing for partially stiffened webs. Designs with un-stiffened webs only have bearing stiffeners and cross frame connection plates shown in Figure 4.1. Interior and Exterior girders were designed for two 2-lanes cross sections: a $28 \mathrm{ft}$ cross section with four girders spaced at 8'-3" (Figure 4.2), and a $34 \mathrm{ft}$ cross section with four girders spaced at 10'-0” (Figure 4.3). Full composite action was assumed between the steel girders and the concrete slab via headed shear studs.

The following parameters were varied for both cross sections:

- Girder type selection: 50-ksi homogeneous plate girder, Hybrid plate girder (50-ksi compression flange and web, 70-ksi tension flange), 50-ksi Rolled beam

- Girder locations: Interior, Exterior

- $\quad$ Target span-to-depth, L/D, ratios: 20, 25, 30

- Stiffened or un-stiffened webs

- Span lengths: $40 \mathrm{ft}$ to $140 \mathrm{ft}$ in $5 \mathrm{ft}$ increments 
Span-to-depth ratios are calculated by using the entire depth of the superstructure, $\mathrm{D}$, which includes the concrete slab, concrete haunch and the steel section. The concrete haunch is the distance from the bottom of the top flange to the bottom of the concrete slab. The stiffened web designs were developed utilizing the "partially stiffened web approach", which involves reducing the un-stiffened web thickness by $1 / 16$ " or $1 / 8$ " to vary the layout of the transverse stiffeners.

The following parameters remained constant for each design:

- Stay-in-place (SIP) forms: 15 psf

- Future wearing surface: $25 \mathrm{psf}$

- Concrete barriers (F-type): $305 \mathrm{lbs} / \mathrm{ft}$

- Miscellaneous steel weight increase: $5 \%$

- Compressive strength of concrete: $4.0 \mathrm{ksi}$

- Concrete unit weight: $150 \mathrm{pcf}$

- Steel unit weight: 490 pcf

- Modular ratio: 8

- Concrete haunch thickness: 2 in

- Constant flange width

- Constant web height

- Construction loads:

o Overhang deck forms: $40 \mathrm{lbs} / \mathrm{ft}$

o Screed rail: $85 \mathrm{lbs} / \mathrm{ft}$

o Railing: $25 \mathrm{lbs} / \mathrm{ft}$ 
o Walkway: $125 \mathrm{lbs} / \mathrm{ft}$

o Finishing machine: $3000 \mathrm{lbs}$

The available flange thicknesses are taken in increments of $1 / 8$ in, and the web plates in increments of 1/16 in. The plate widths are taken in 2 in increments. Minimum plate sizes were set to ensure ease of fabrication and reduce problems associated with flange distortion due to welding. The minimum allowable flange size was 12 in wide and $3 / 4$ in thick. The minimum permitted web size was 24 in by $7 / 16$ in. Flange transitions were allowed at $20 \%$ of the span length if the transition would save $800 \mathrm{lbs}$ of steel to save the cost of fabrication.

\subsection{Design Approach}

One of the goals of this study was to develop a user friendly and detailed document for each design alternative. For this purpose, an extensive design document in Microsoft Excell was prepared. The spreadsheet details the entire girder design from entering initial design parameters to optimizing the final design. The accuracy and effectiveness of the computation sheet was verified through Steel Bridge, by Bridgesoft (2003). The document allows more convenient design process and provides the benefit of visibility through each design step. All the design sections are equipped with tables and references to the $3^{\text {rd }}$ Edition of the AASHTO LRFD Bridge Design Specifications (AASHTO 2004) to provide not just clarity through the design process but also to provide detailed references. 
Every girder design started by computing the web depth based on the proposed span-to-depth ratio (L/D). For the purpose of this study, three target ratios were selected: 20, 25 and 30. For shorter span lengths only one design was developed with span-todepth ratios less than 20 , due to previously mentioned plate size restrictions. The target overall depth of the superstructure was determined from the $\mathrm{L} / \mathrm{D}$ ratio. By subtracting the concrete slab thickness, the concrete haunch thickness and the bottom flange thickness, the web height was determined. That value was rounded up to the nearest even number to satisfy the web increment of 2 inches criteria.

After the web depth was determined, a preliminary flange width was selected to satisfy to the ratio of web depth and flange width to be between 3.0 and 4.0, if possible. Due to plate restrictions, some sections were not able to satisfy the aspect ratio. The initial flange width and thickness was always set to the minimum allowed based on the plate restrictions. Cross frame spacing was based on span length and was set at equal distance at $1 / 4$ of the span length. The maximum cross frame spacing was set at $30 \mathrm{ft}$.

Following the selection of the initial cross section height, the web thickness was determined. Initially, webs were designed such that no transverse stiffeners were required. Depending on the cost savings and the capacity of the unstiffened design, a partially stiffened web thickness was determined by subtracting $1 / 16$ " or $1 / 8$ " from the web thickness. Once the initial cross section was selected, the above mentioned spreadsheet was used to calculate the section properties. Moment and shear envelopes 
were extracted from the commercial software program ConSys 2000 (Leap Software, Consys 2000). This last step was repeated until the optimized section was found.

To evaluate the effect of the live-load deflection criteria on the girder weight, the sections were first optimized to satisfy all design limit states neglecting the optional liveload deflection limit. If the optimized girder did not satisfy the deflection limit, a separate girder was designed to meet the criteria. According to Article 6.10.4.2, to evaluate liveload deflections on girders with shear connectors provided throughout the entire length, short term or long term composite section may be used to evaluate stresses and live-load deflection from Service II load combinations. Hence, in this study live-load deflections were computed using the short-term composite section.

\subsection{Design Summary and Observations}

This section describes the summary and observation from the optimized parametric design study. The girders discussed in this section are both interior and exterior that were designed according to the $3^{\text {rd }}$ Edition of the AASHTO LRFD Bridge Design Specifications. Appendix A presents design summaries for all girders. 


\subsubsection{Influence of Material Configuration}

Figures 4.4 through 4.13 show the weight versus span-to-depth ratio for homogeneous and hybrid girder configurations for both locations, exterior and interior. The weight corresponds to a single girder for span lengths of 140 feet, 120 feet, 100 feet, 80 feet, and 60 feet. From the figures, it can be seen that hybrid material configuration results in a lighter design than the homogeneous sections for longer spans in this study. Span lengths of 50 feet and shorter do not benefit from the use of a hybrid girder configuration since the sections are controlled by minimum plate size restrictions. Hybrid girders that did not satisfy the L/800 Deflection limit are significantly lighter than the homogeneous girders for higher $\mathrm{L} / \mathrm{D}$ ratios.

Exterior hybrid girders are approximately $8.8 \%$ lighter than homogeneous members for sections that satisfy the L/800 deflection criteria and also when neglecting the optional deflection criteria. In the case of interior designs, hybrid sections that satisfy the $\mathrm{L} / 800$ deflection criteria are on average $8.7 \%$ lighter than homogeneous members, and when $\mathrm{L} / 800$ is neglected, hybrid sections were found to be $10.0 \%$ lighter than the homogeneous designs.

\subsubsection{Optimum Span-to-Depth Ratio}

The span-to-depth ratio has a significant impact on girder design economy. In general, higher span-to-depth ratios result in heavier sections for both homogeneous and 
hybrid girder configurations. Figure 4.4 shows an exterior girder weight comparison of 140 feet span length, where the hybrid section with the higher span-to-depth ratio, 27.5 weighs 21.9 percent heavier than the optimum span-to-depth ratio of 24.9. figure 4.11 shows an additional example where the difference of 25.5 percent for a homogeneous girder configuration between span-to-depth ratios of 22 and 24.1 .

Another notable observation is that the optimum span-to-depth ratio decreases as the span length decreases. The optimum span-to-depth ratio for span lengths between 95 feet and 140 feet is approximately 24 while for shorter span lengths the optimum span-todepth ratio is approximately 20 , the smallest target design ratio.

\subsubsection{Interior and Interior girder Design}

The optimized design package includes both exterior and interior girder designs in order to compare weight differences based on section location and Figures 4.14 through 4.21 shows the girder weight versus span-to-depth ratios of selected homogeneous and hybrid section. In general, exterior girder designs required more steel than interior sections.

To describe the differences more specifically, interior girders with homogeneous configuration were generally controlled by permanent deformations while hybrid girders were controlled by the construction limit state requirements. While for exterior girders, 
they were generally controlled by either the construction requirements in case of hybrid girders, or permanent deformations for homogeneous girders.

Construction limit state requirements have a significant influence on the design of exterior girders due to lateral bending stresses in the compression flange developed during deck placement. Temporary bracing was implemented at mid-span for exterior girders with span lengths of 75 feet and above during construction. This served a purpose to lower the value of the un-braced length, which in some cases eliminated or minimized the amplification factor during the computation of the lateral bending stresses in the compression flange.

\subsubsection{Influence of a Partially Stiffened Web}

As previously described, sections were designed for un-stiffened and partially stiffened webs. Figures 4.22 through 4.27 show the comparisons between the two types of designs. There was an overall average weight difference of $7.5 \%$ between the unstiffened and partially stiffened designs. Exterior girders realized an $8.8 \%$ difference while interior designs with partially stiffened webs were $6.2 \%$ lighter than un-stiffened sections.

It is notable to mention, that stiffened designs that did not weight less than the unstiffened web sections all have larger span-to-depth ratios. These sections must be significantly increased to meet the flexural requirements under the strength limit state. 
Typically, homogeneous designs offered no weight savings because of the above mentioned flexural capacity.

\subsubsection{Weight Comparison of Rolled Beams}

Rolled beams were found to be more economical as span lengths decreased, namely for span lengths 40 feet to 50 feet. Figures 4.28 to 4.39 show the relationship between girder weight and span-to-depth ratio for rolled sections as they are compared to homogeneous and hybrid designs. Longer span lengths require significantly heavier sections than the plate girder design options since rolled beams are manufactured with shallower depths. Despite of the weight disadvantage, span lengths of 50 feet to 85 feet, rolled beams require an average 19\% more steel than homogeneous and $29 \%$ more than hybrid plate girder alternatives, which could be offset by steel and fabrication cost.

\subsubsection{Influence of Span-to-Depth Ratio on Live-load Deflection Criteria}

The span-to-depth ratio has a significant influence on the Live-load deflection criteria. Figures 4.40 through 4.49 are graphs of the deflection versus span-to-depth ratios for selected girder lengths. The $\mathrm{L} / 800$ optional live-load deflection limit is presented with a black dashed line. From the figures it can be observed, that the majority of the girders that did not meet the $\mathrm{L} / 800$ criteria have higher span-to-depth ratios. Since the deflection criteria is a function of the moment of inertia of the composite cross section, it is self explanatory that girders with higher span-to-depth ratios have shallower depths and will 
fail the criteria more often that with girders of higher L/D ratios. Also of note, the girders with the lowest of the three target span-to-depth ratios never failed the deflection criteria.

\subsubsection{Influence of Material Configuration on Live-load Deflection Criteria}

In this optimization study, the hybrid configuration failed the initial live-load

deflection limit more often than the homogeneous sections. In this design study, a total of 22 designs failed the $\mathrm{L} / 800$ deflection criteria and all of the girders that failed the deflection criteria were hybrid girders.

To better illustrate the rate of the additional steel required, the average deflection by which the girders were failing the limit was compared to the additional steel required to satisfy the limit. Hence, exterior girders failed the L/800 deflection criteria by an average of 0.057 inches and required $4 \%$ more steel to meet the criteria, while interior girders failed the $\mathrm{L} / 800$ deflection criteria by an average of 0.123 inches and required $5.5 \%$ more steel to satisfy per girder. Approximately similar ratios apply to the interior designs that failed the live-load deflection limit. Therefore, the optional live-load deflection limit can have a negative impact on steel I-girder designs. 


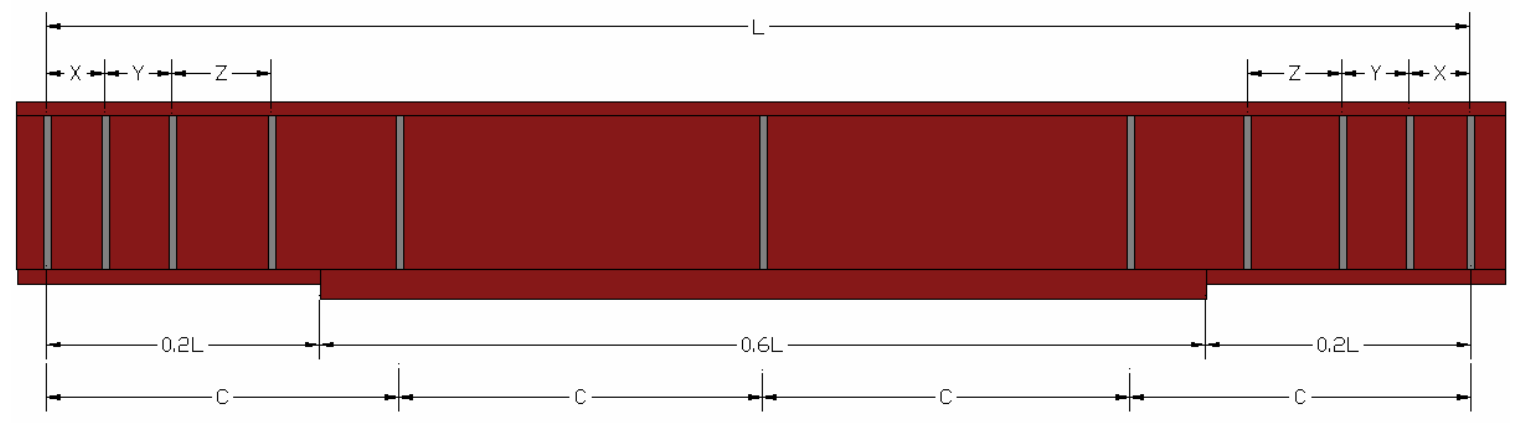

Figure 4.1 Typical Girder Elevation

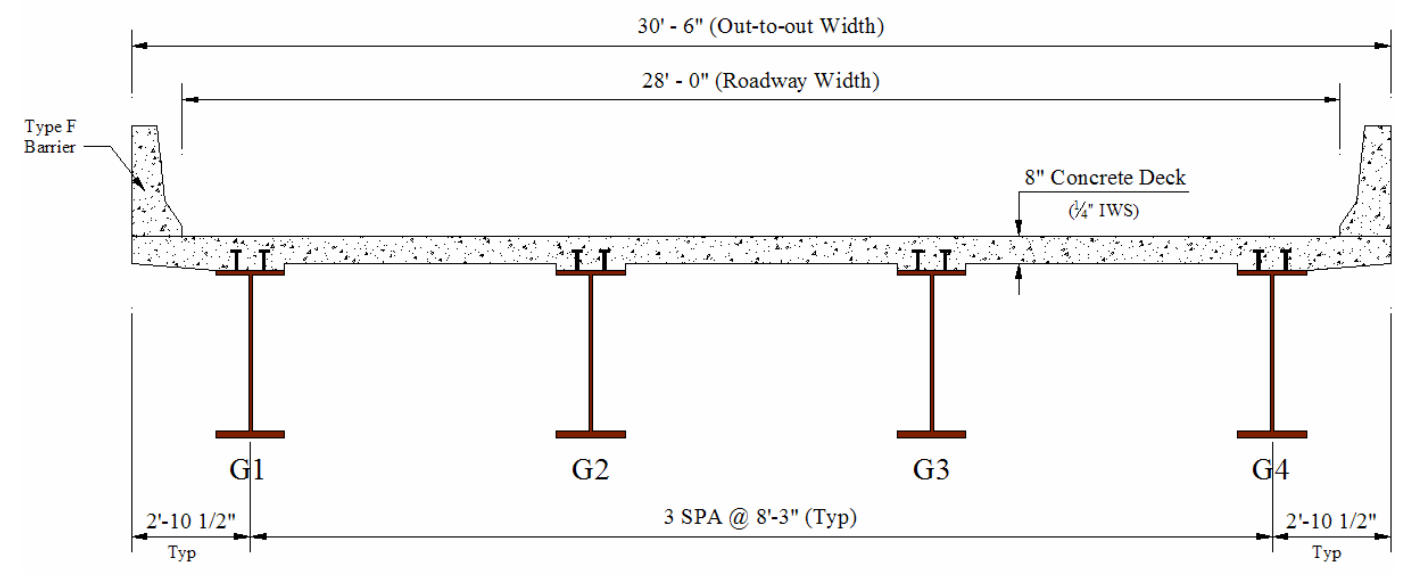

Figure 4.2 Bride Cross-section with 28-ft. Clear Roadway Width

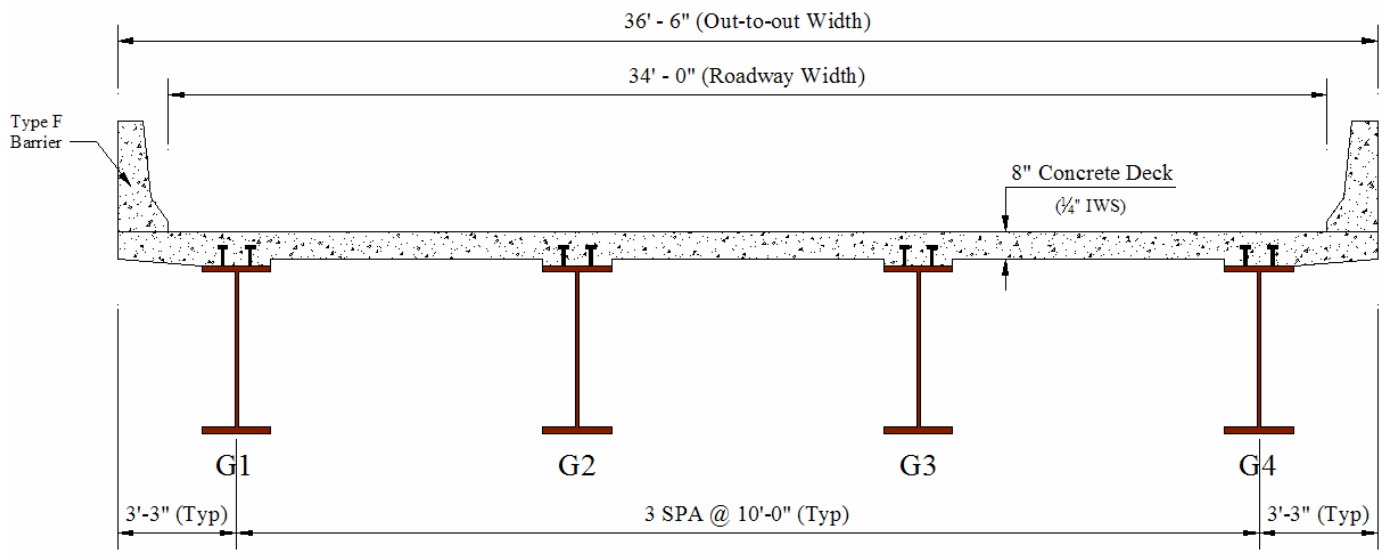

Figure 4.3 Bride Cross-section with 34-ft. Clear Roadway Width 


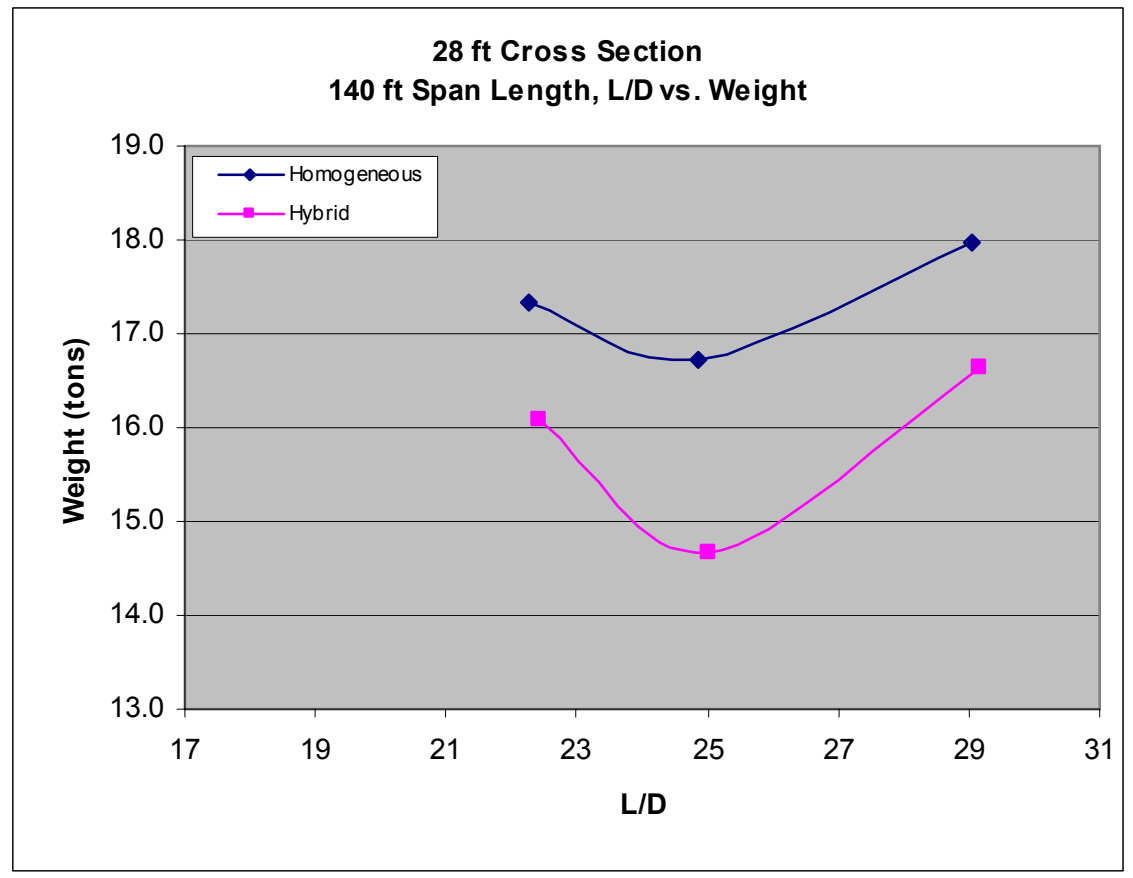

Figure 4.4 Exterior Girder Designs

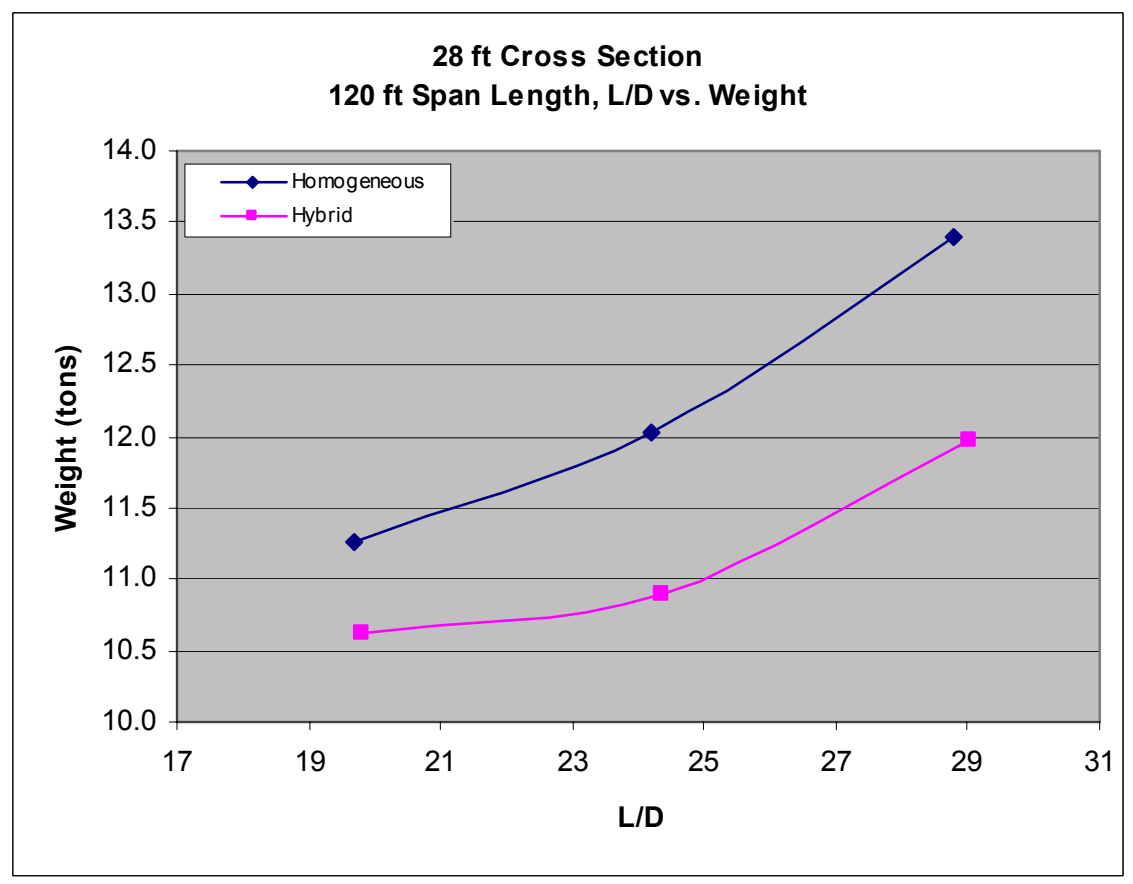

Figure 4.5 Exterior Girder Designs 


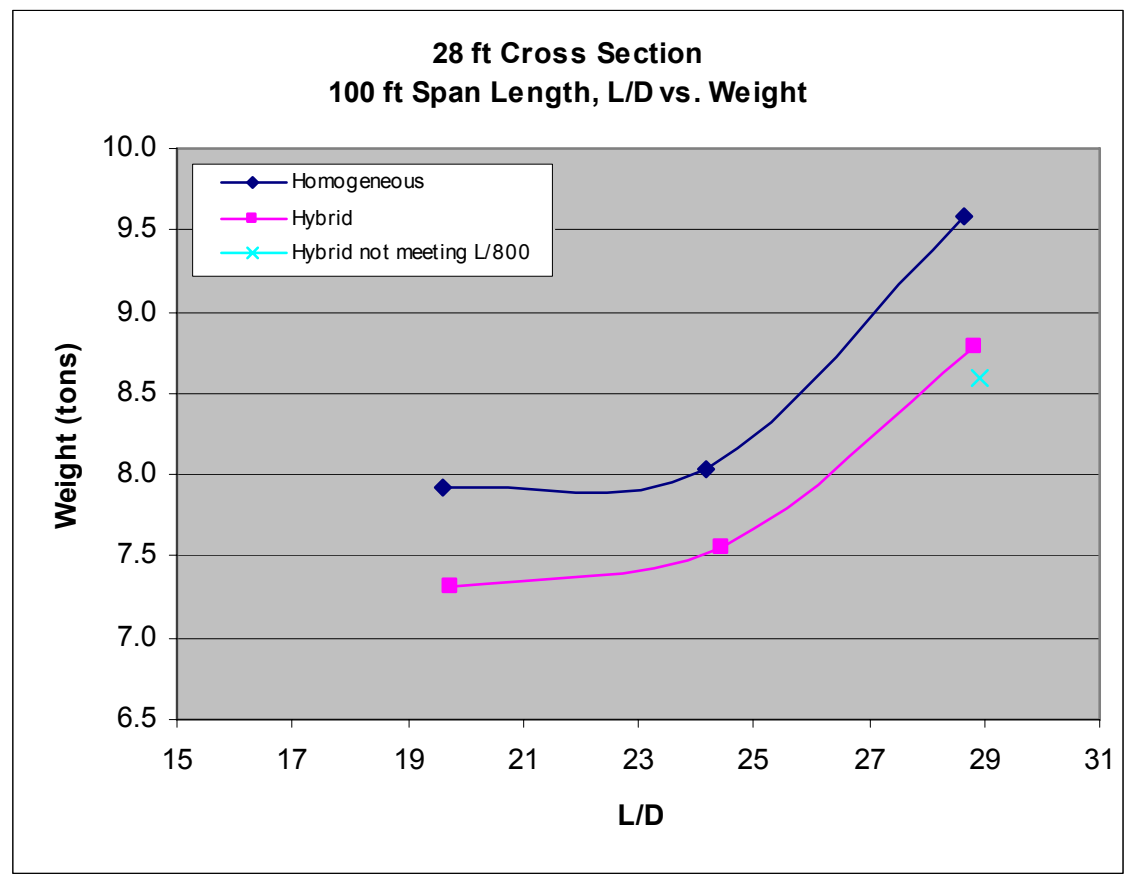

Figure 4.6 Exterior Girder Designs

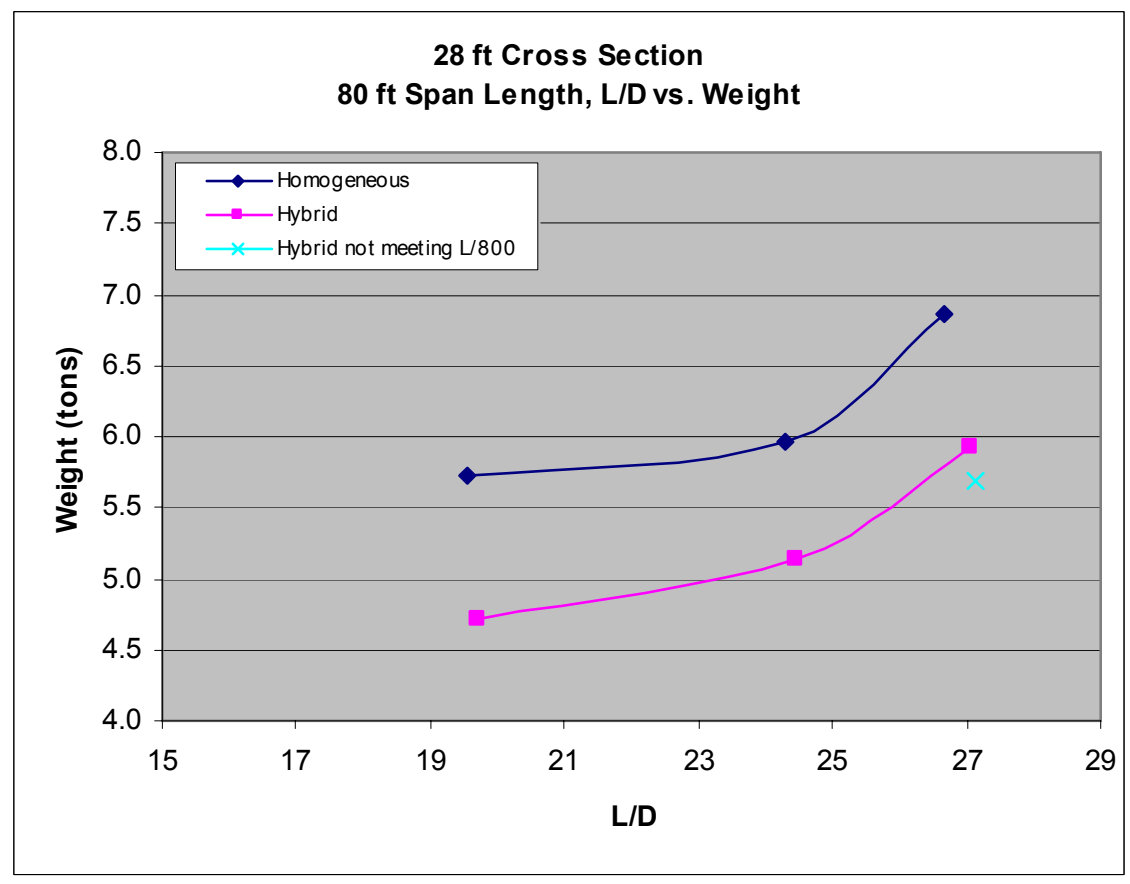

Figure 4.7 Exterior girder Designs 


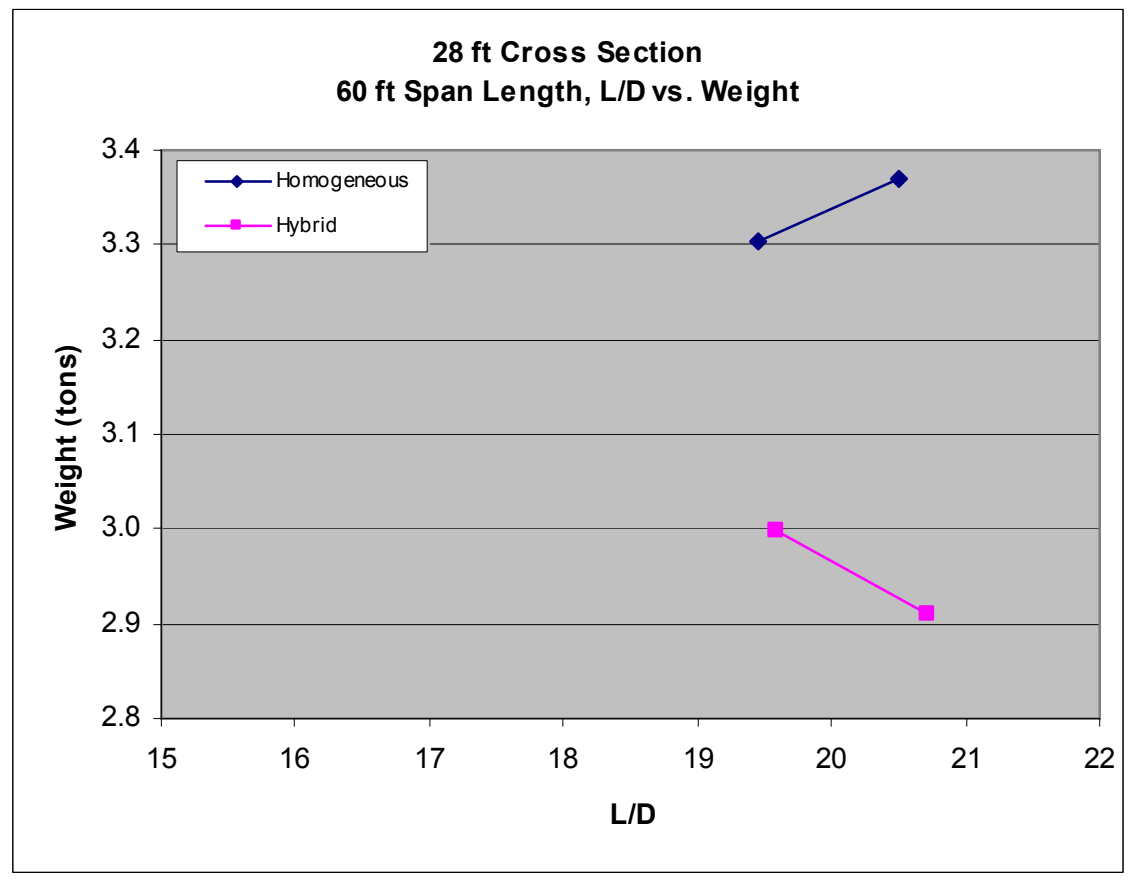

Figure 4.8 Exterior Girder Designs

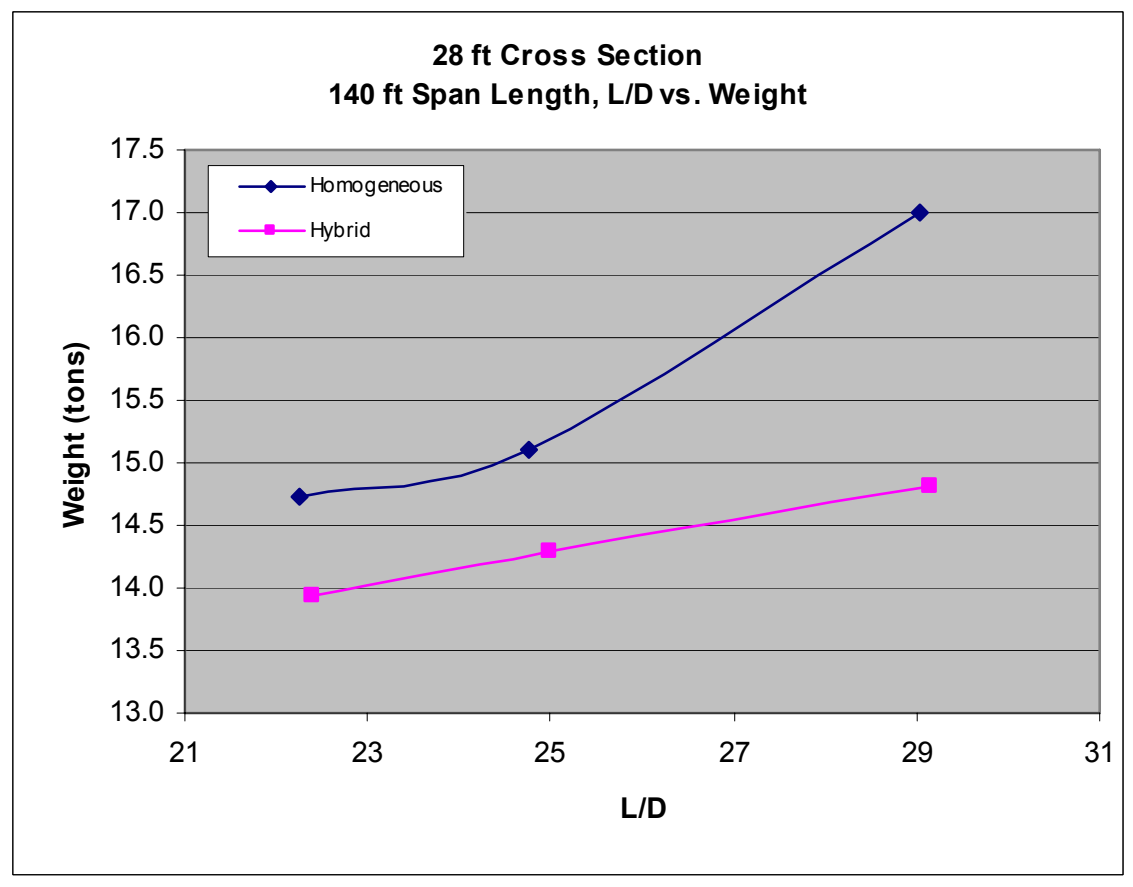

Figure 4.9 Interior Girder Designs 


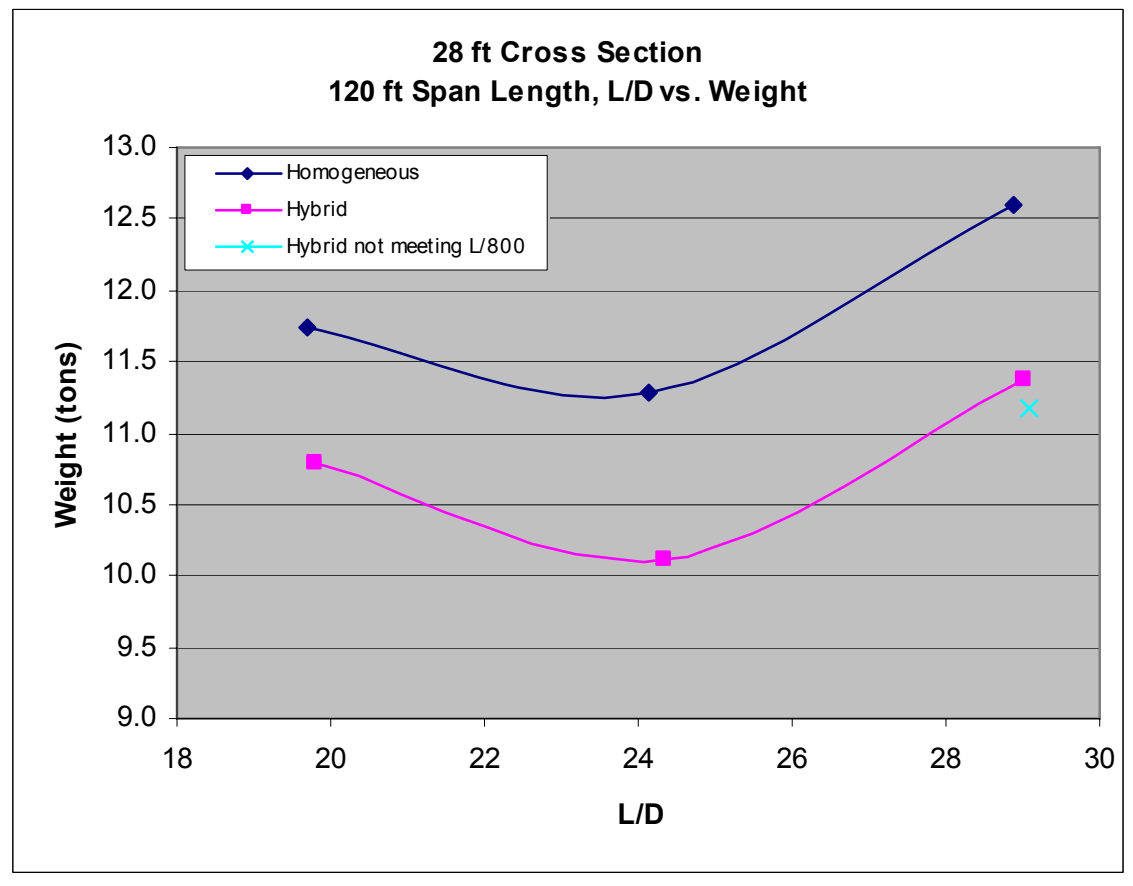

Figure 4.10 Interior Girder Designs

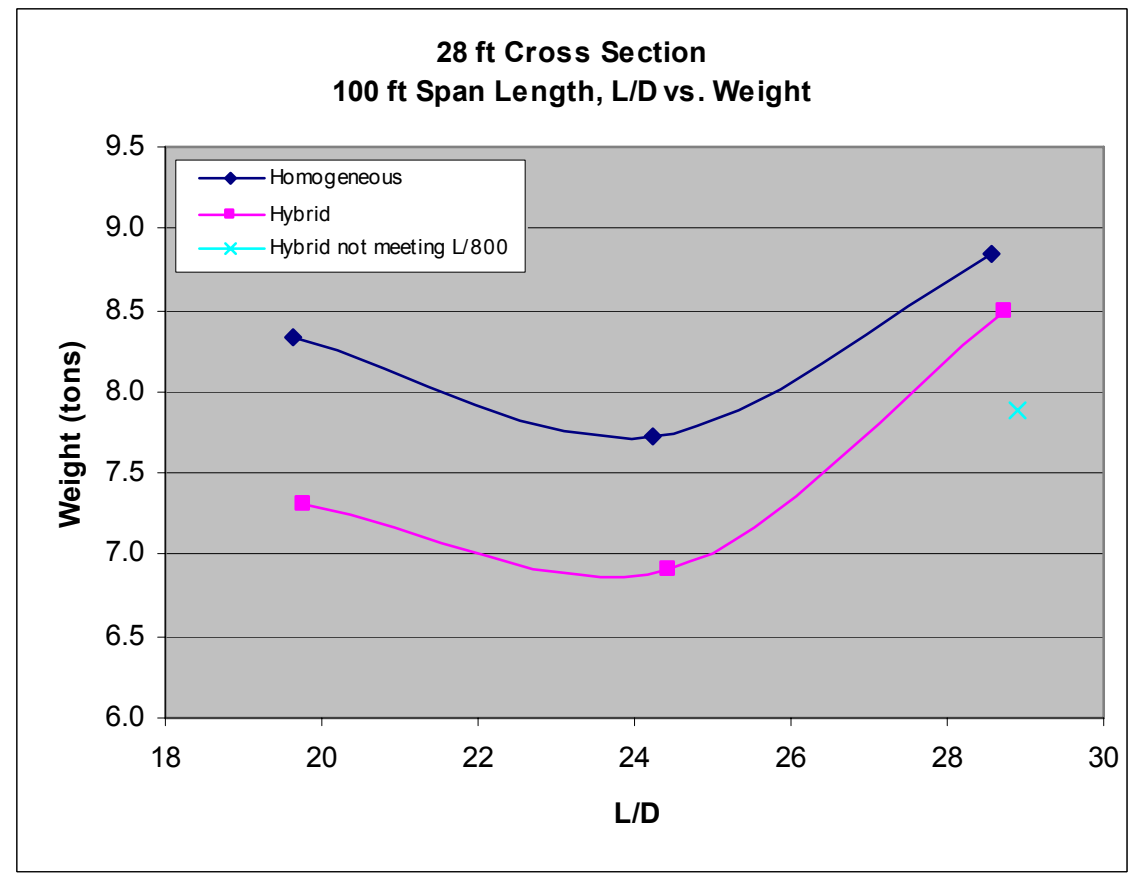

Figure 4.11 Interior Girder Designs 


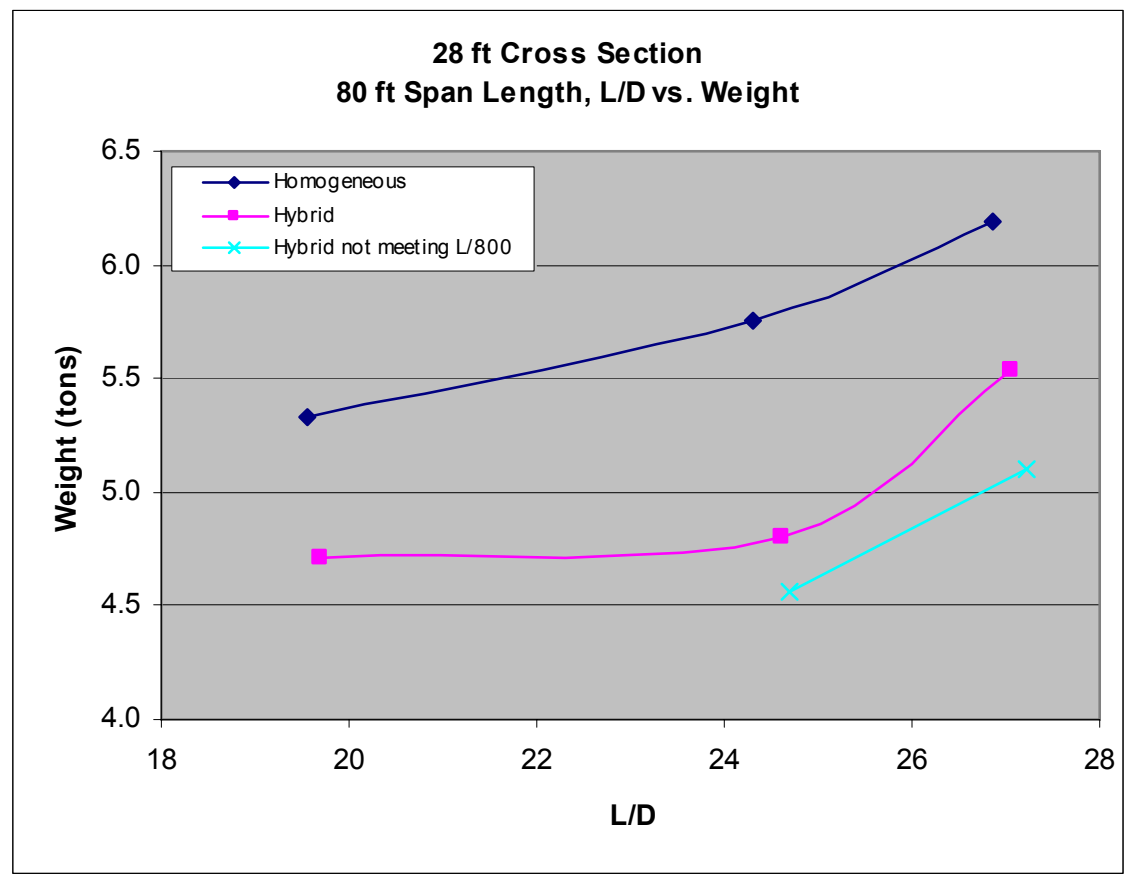

Figure 4.12 Interior Girder Designs

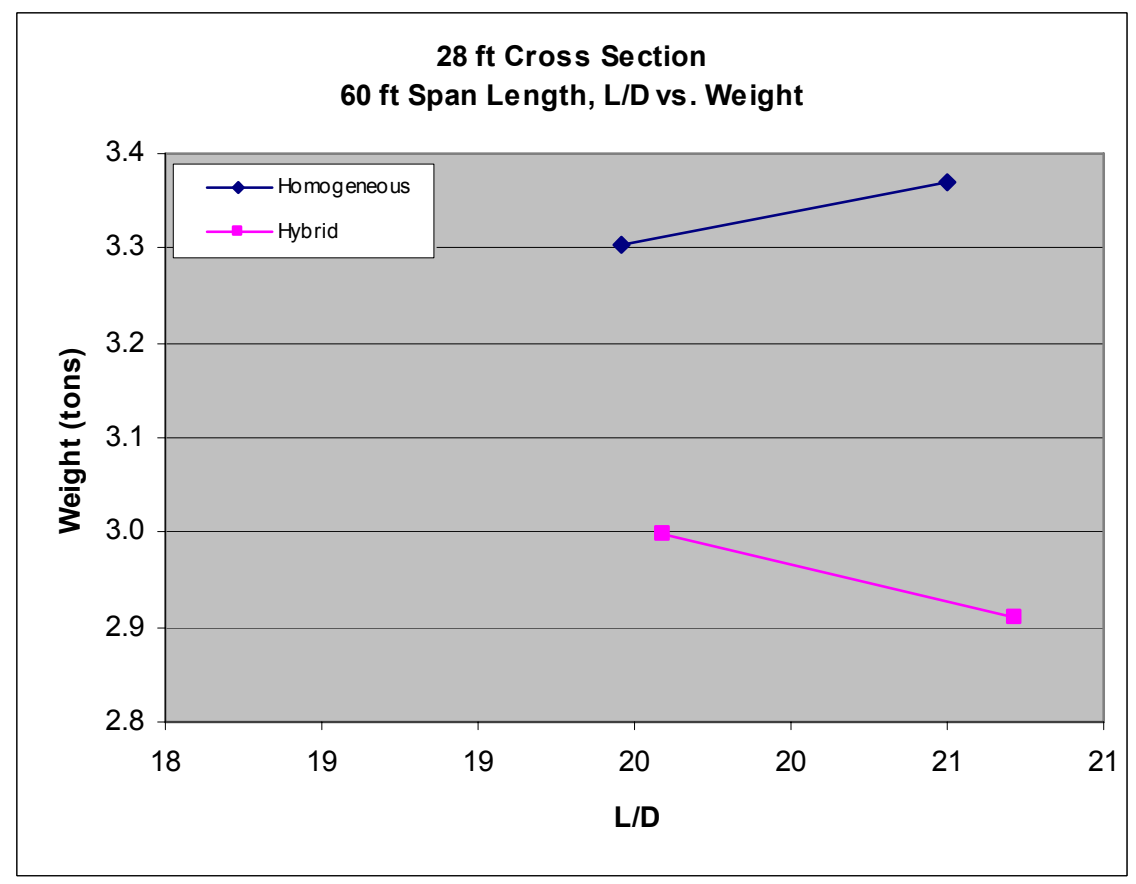

Figure 4.13 Interior Girder Designs 


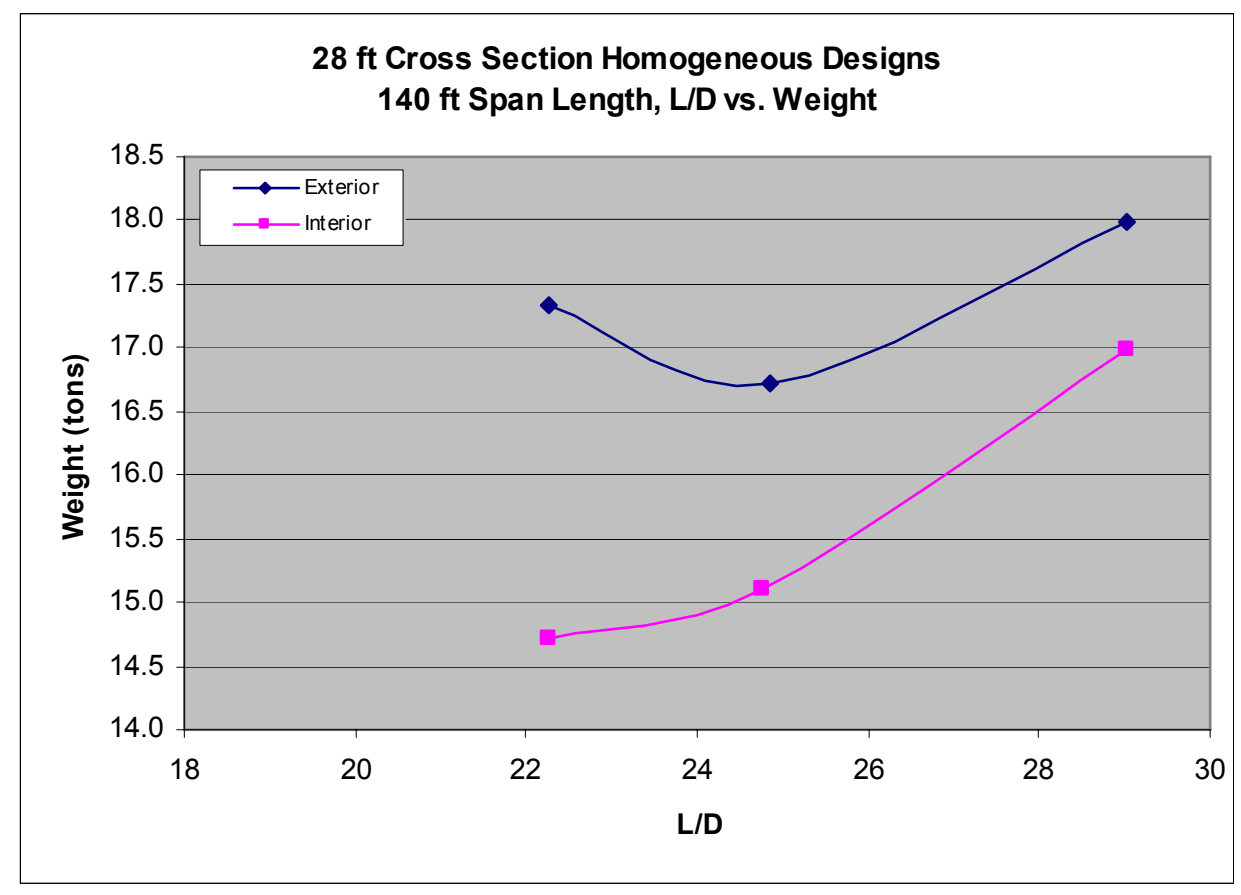

Figure 4.14 Interior vs. Exterior Girder Designs

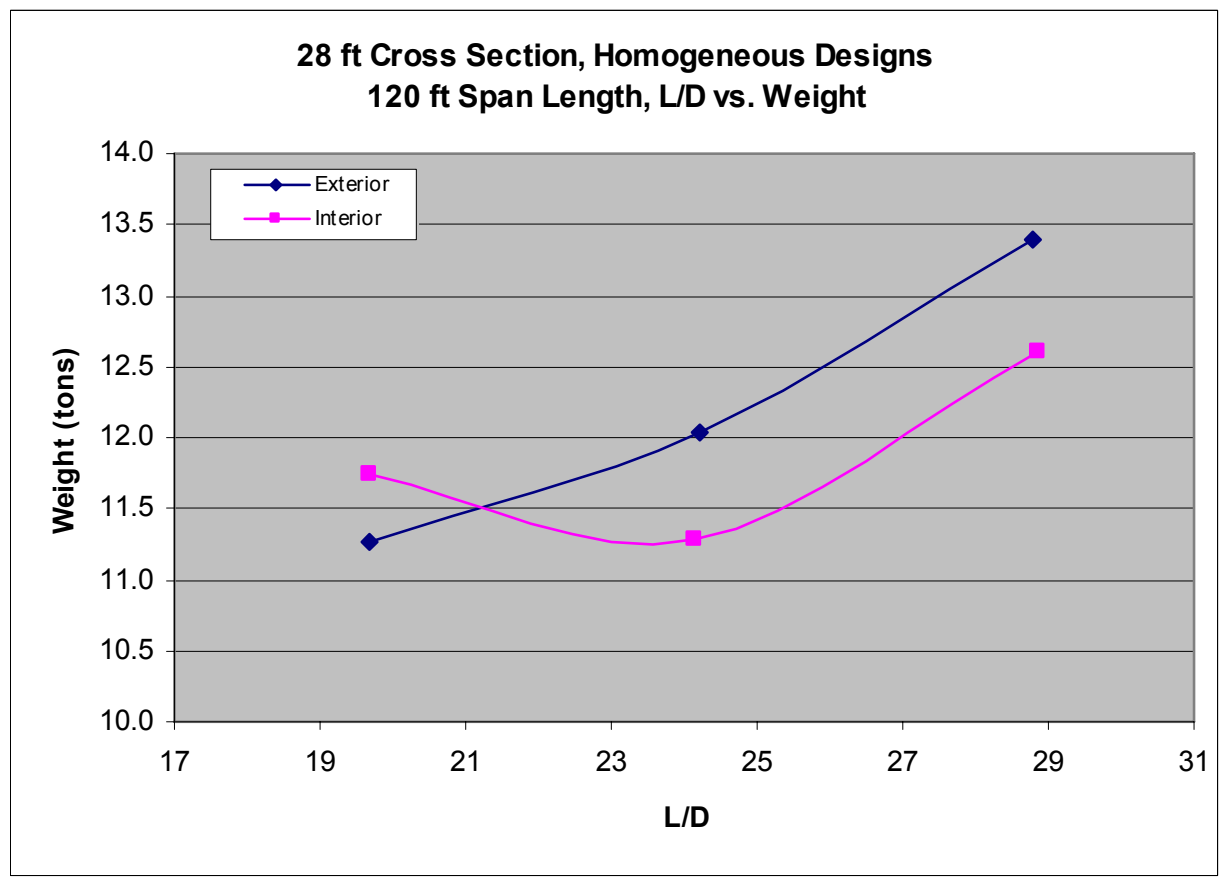

Figure 4.15 Interior vs. Exterior Girder Designs 


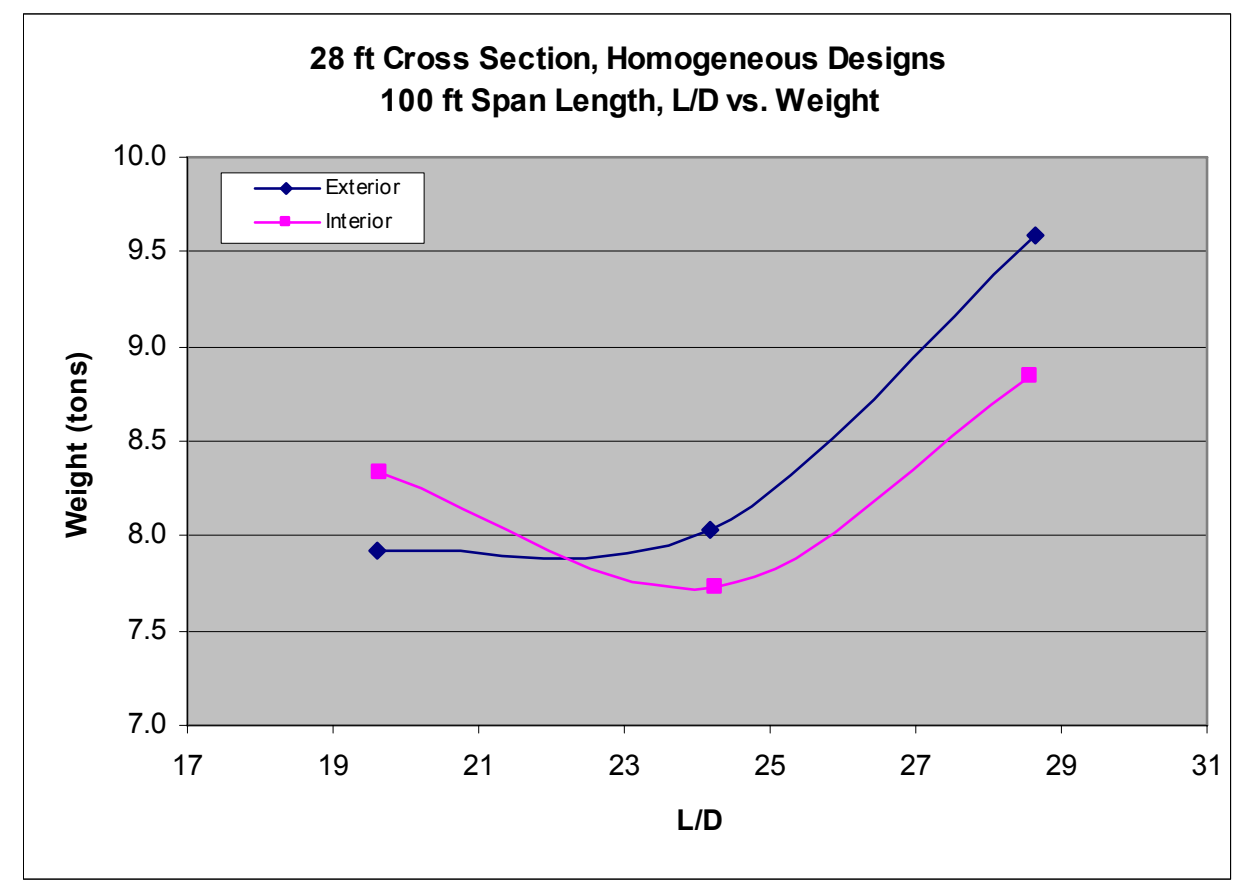

Figure 4.16 Interior vs. Exterior Girder Designs

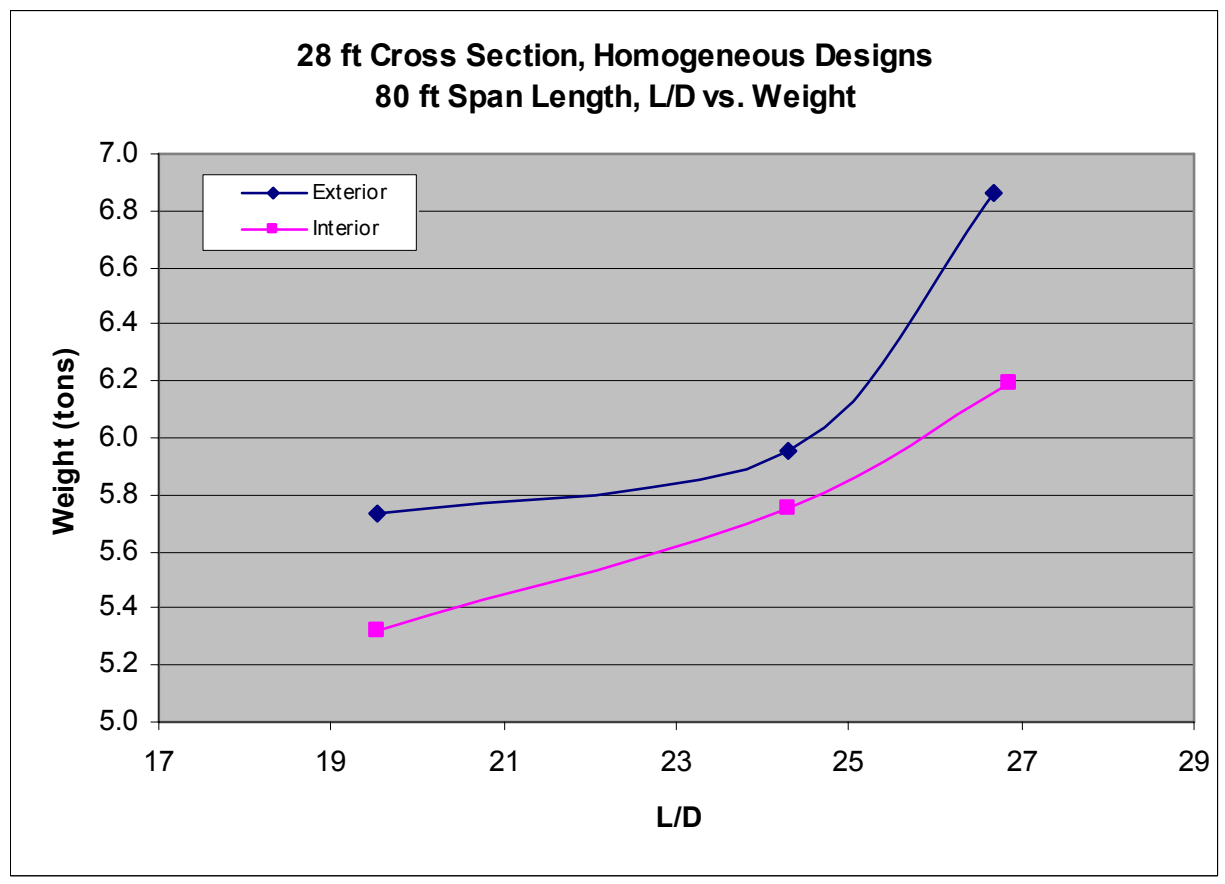

Figure 4.17 Interior vs. Exterior Girder Designs 


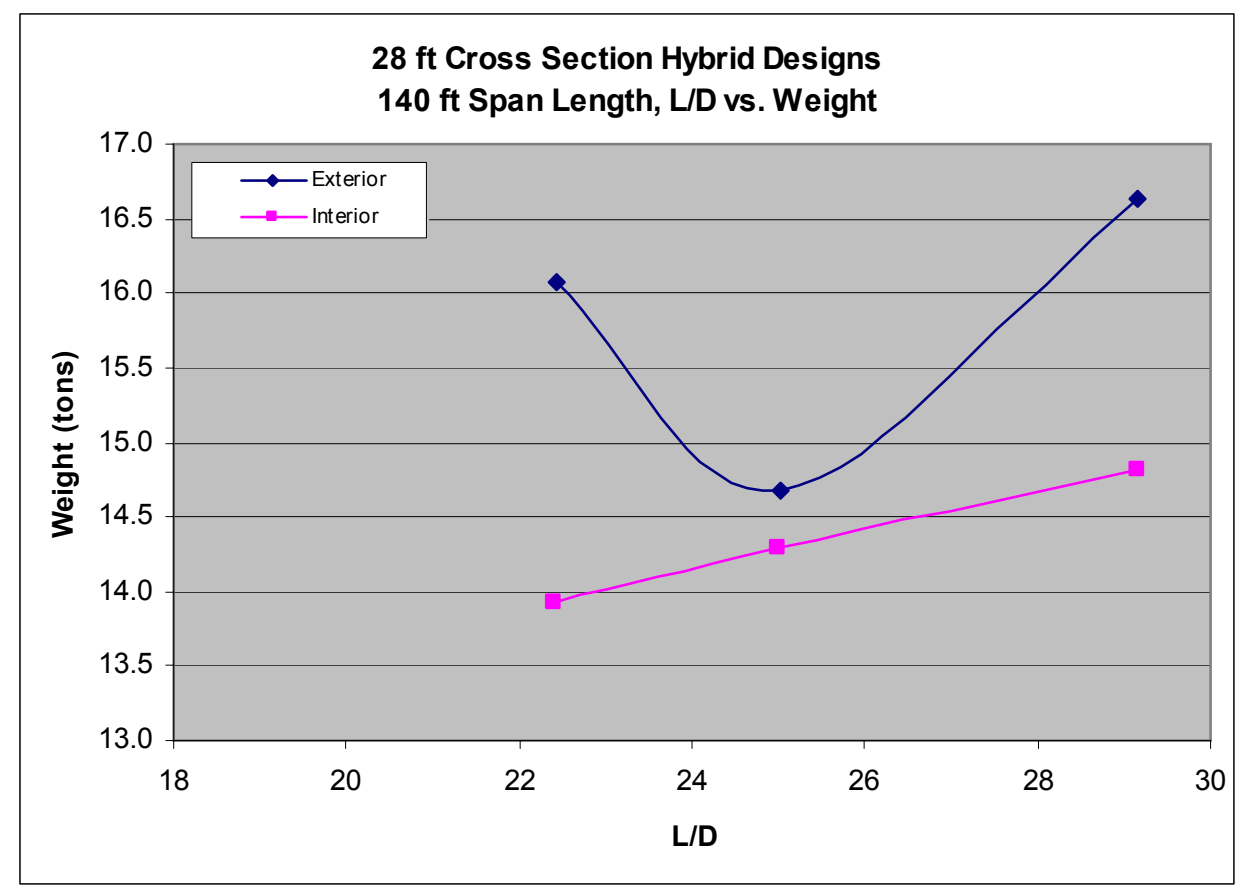

Figure 4.18 Interior vs. Exterior Girder Designs

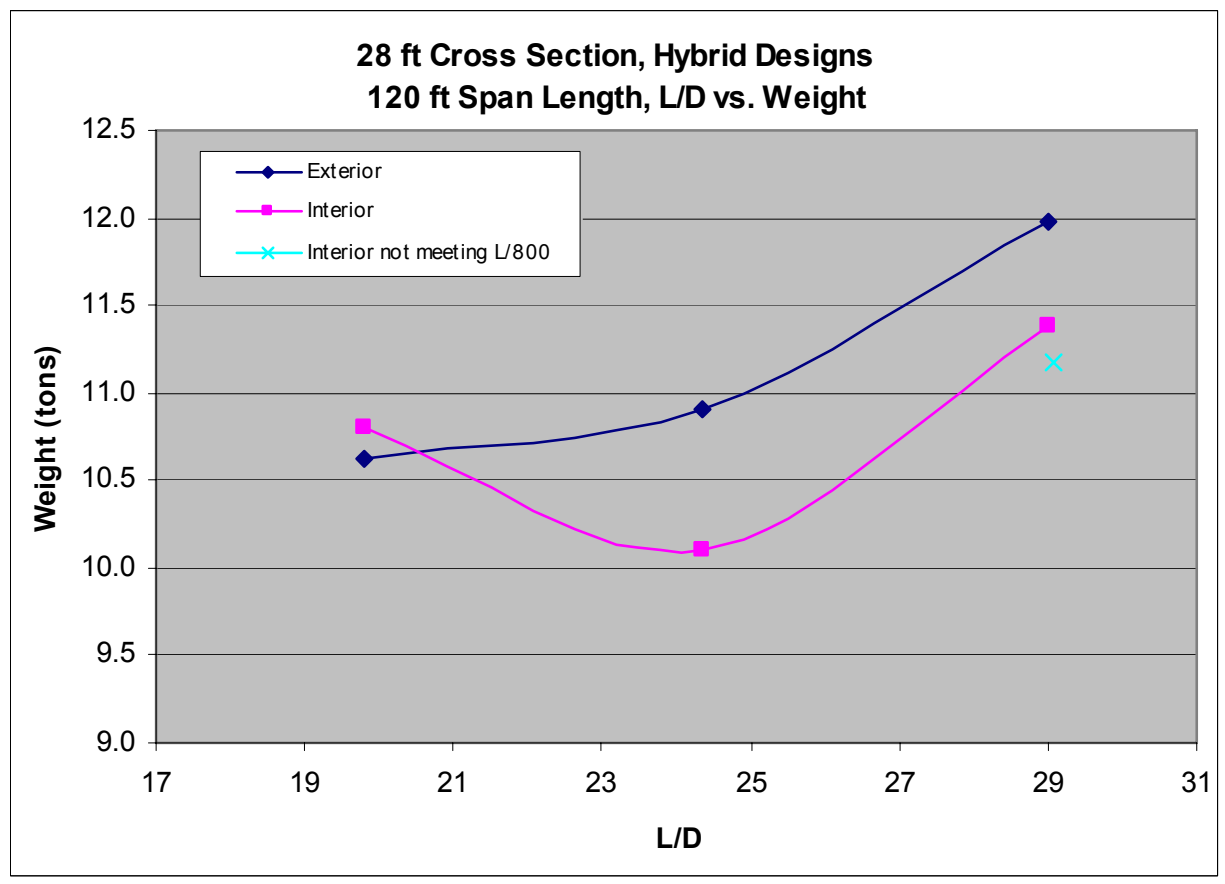

Figure 4.19 Interior vs. Exterior Girder Designs 


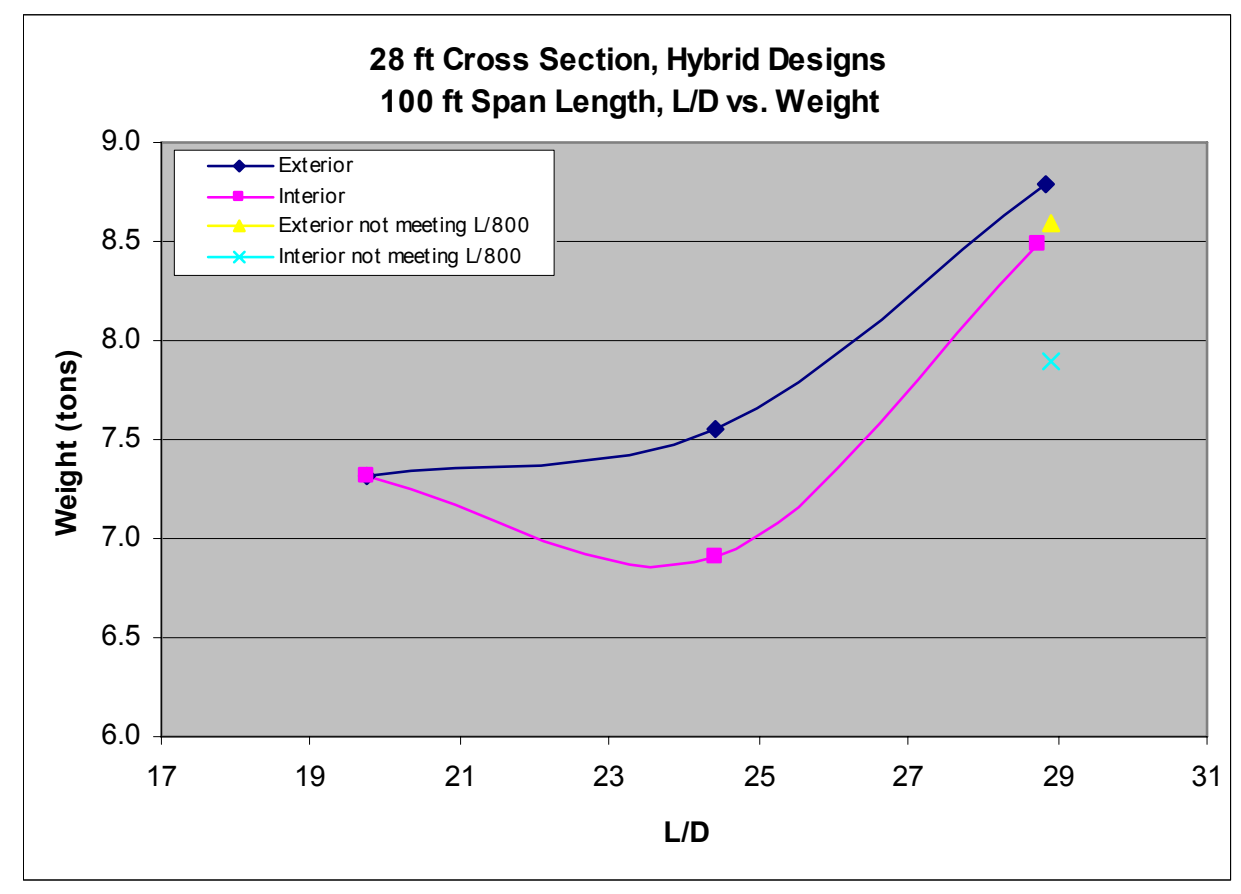

Figure 4.20 Interior vs. Exterior Girder Designs

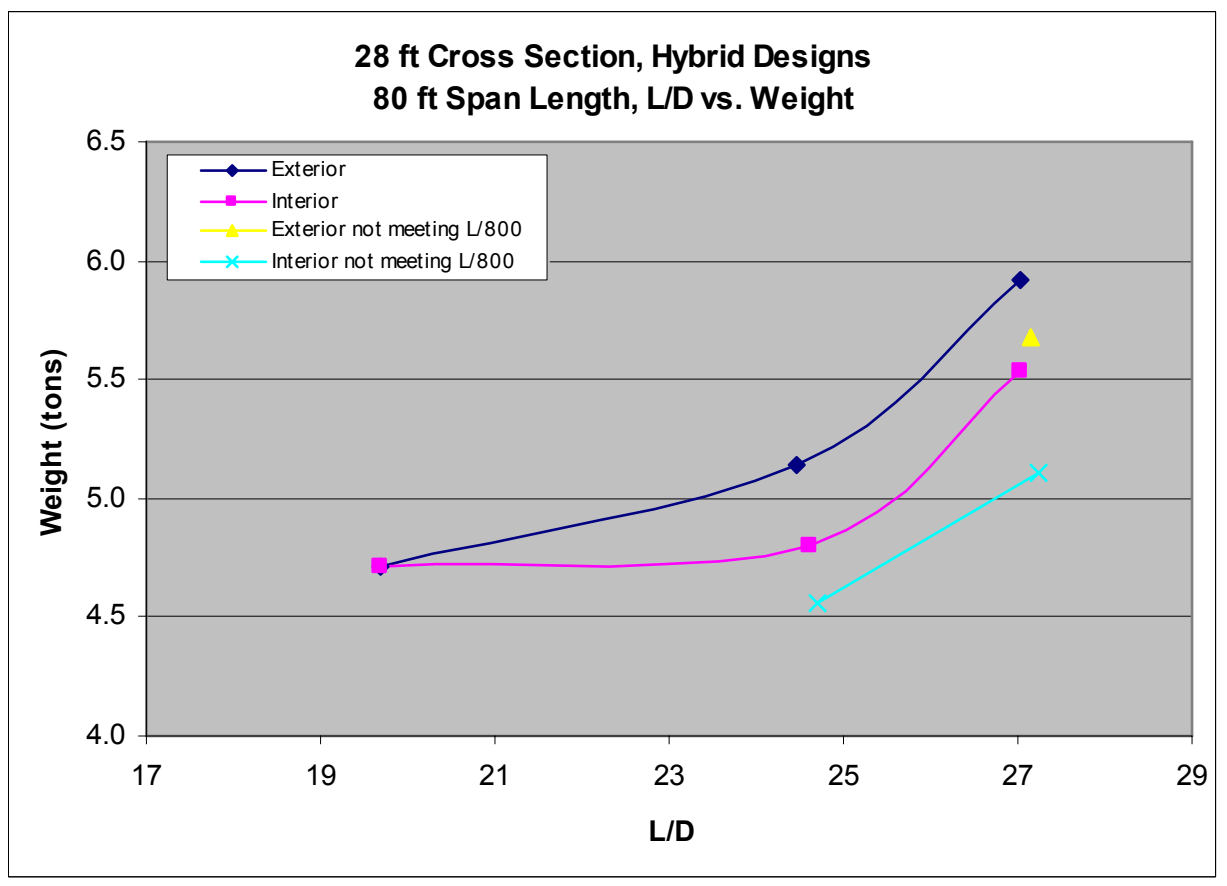

Figure 4.21 Interior vs. Exterior Girder Designs 


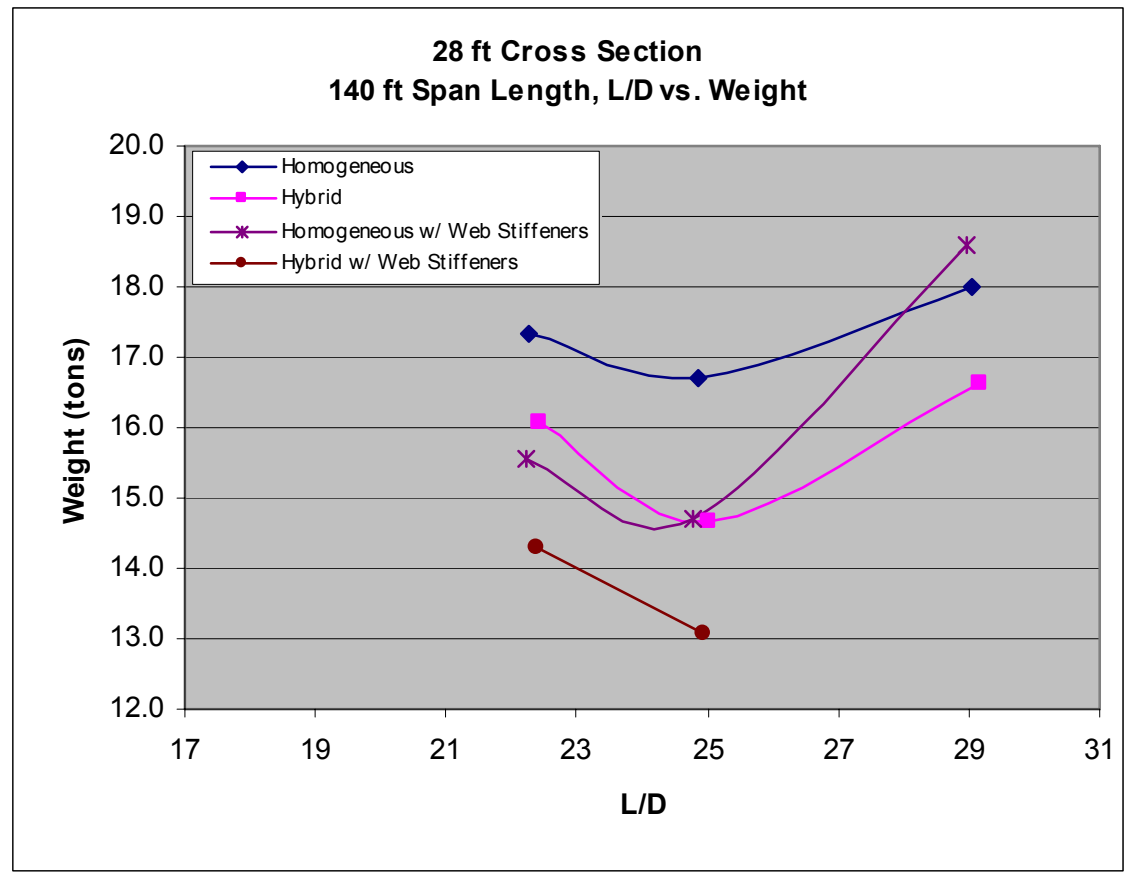

Figure 4.22 Partially Stiffened Web Exterior Girder Designs

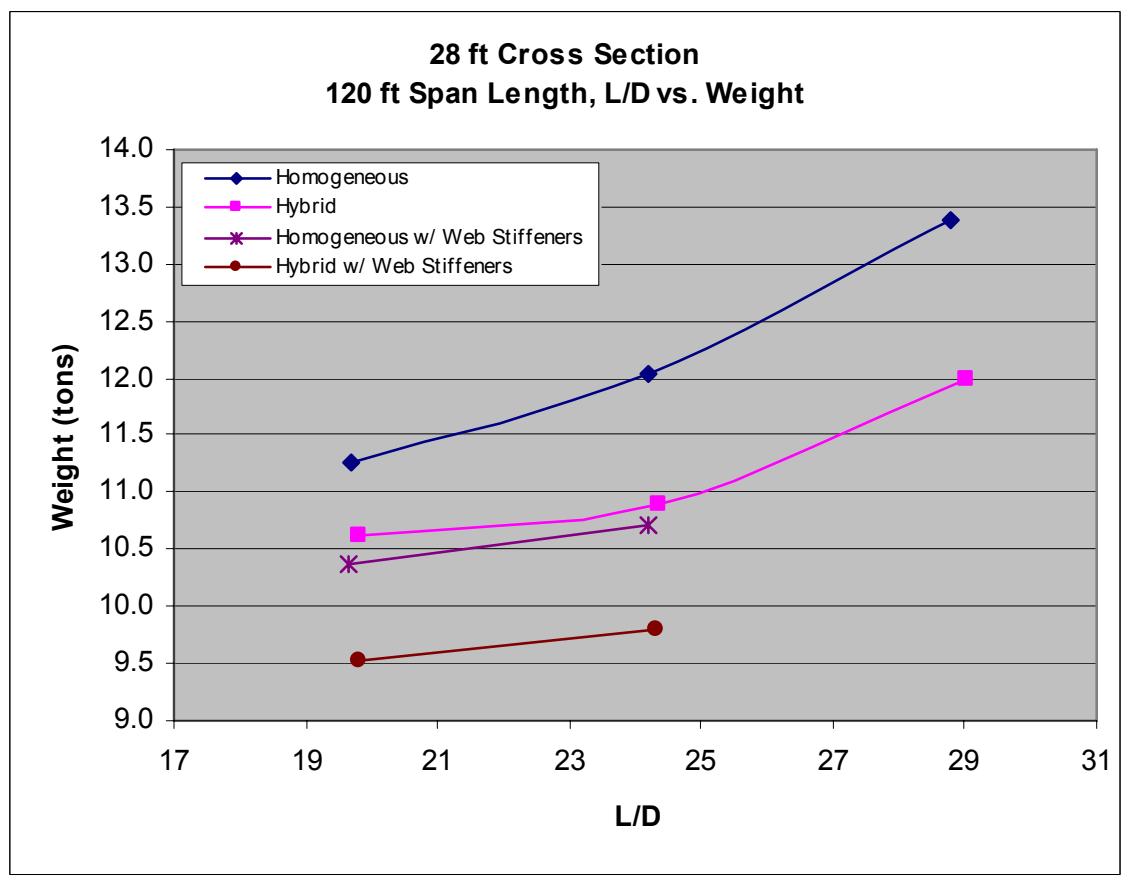

Figure 4.23 Partially Stiffened Web Exterior Girder Designs 


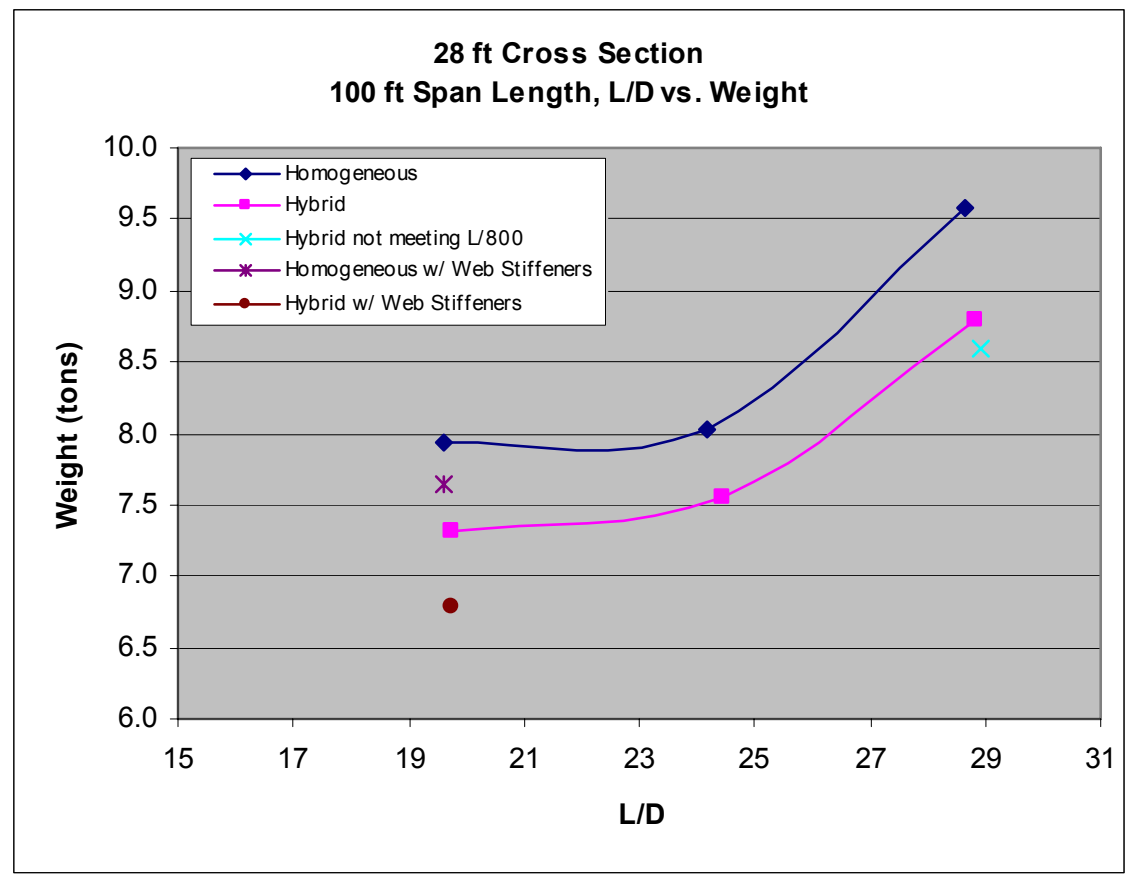

Figure 4.24 Partially Stiffened Web Exterior Girder Designs

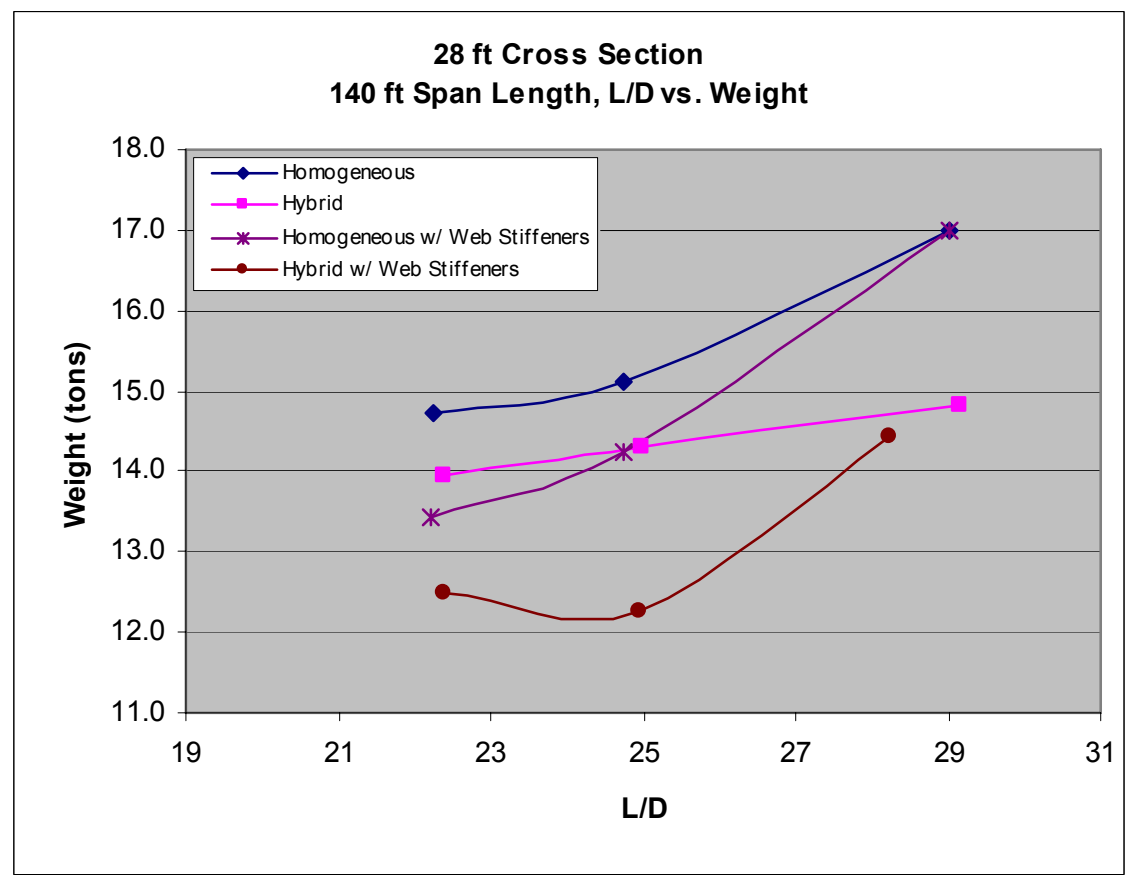

Figure 4.25 Partially Stiffened Web Interior Girder Designs 


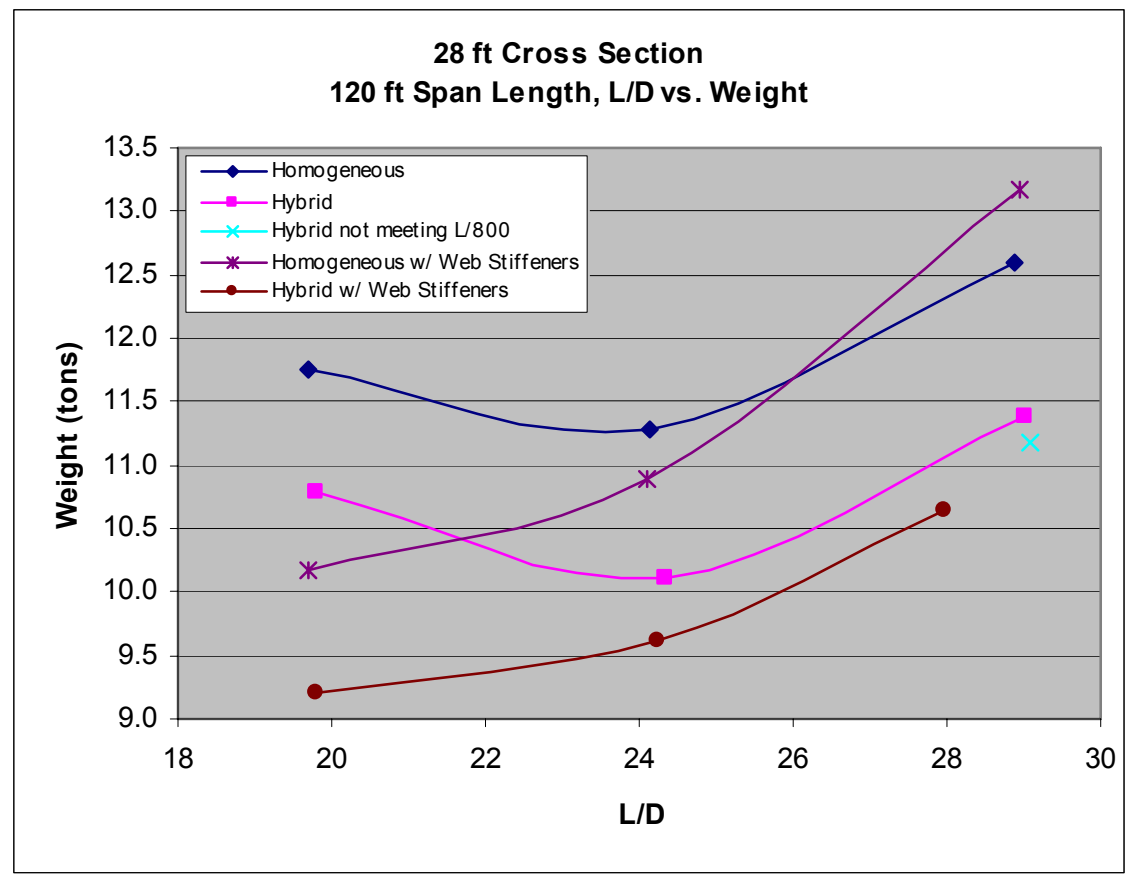

Figure 4.26 Partially Stiffened Web Interior Girder Designs

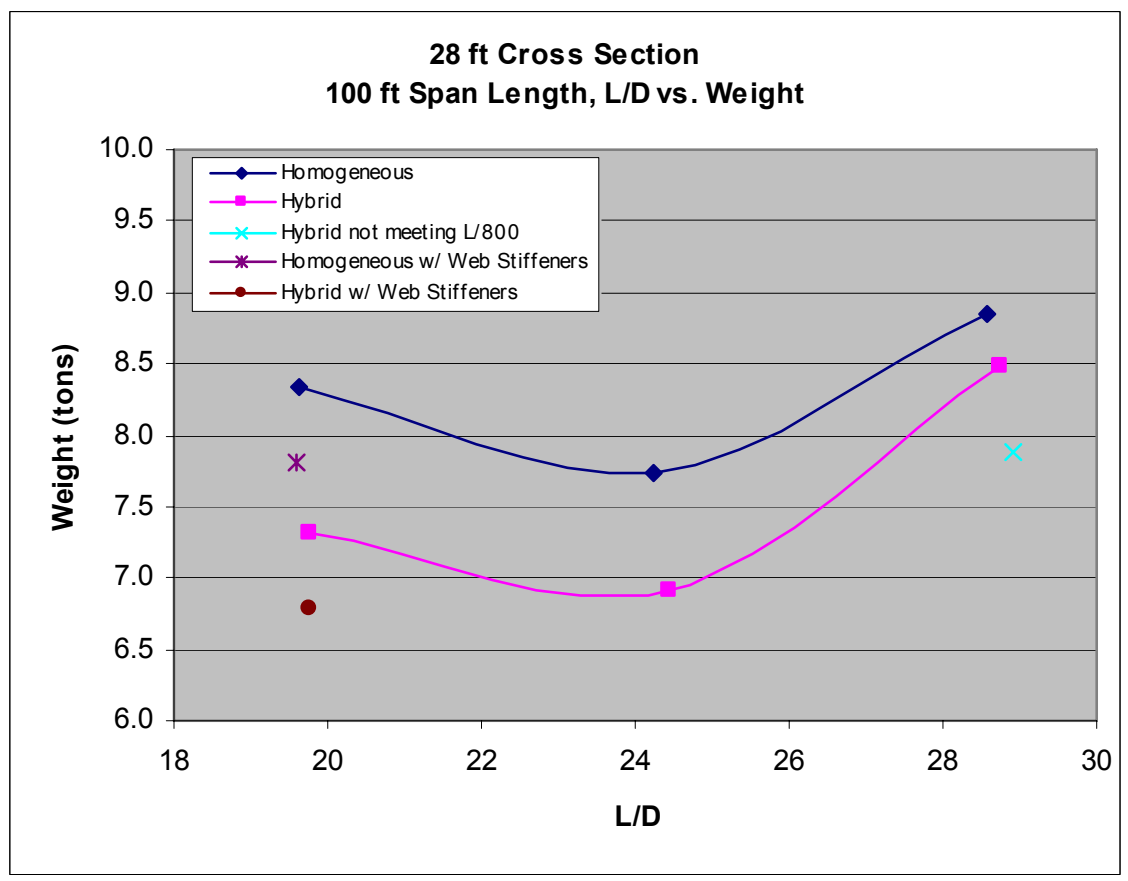

Figure 4.27 Partially Stiffened Web Interior Girder Designs 


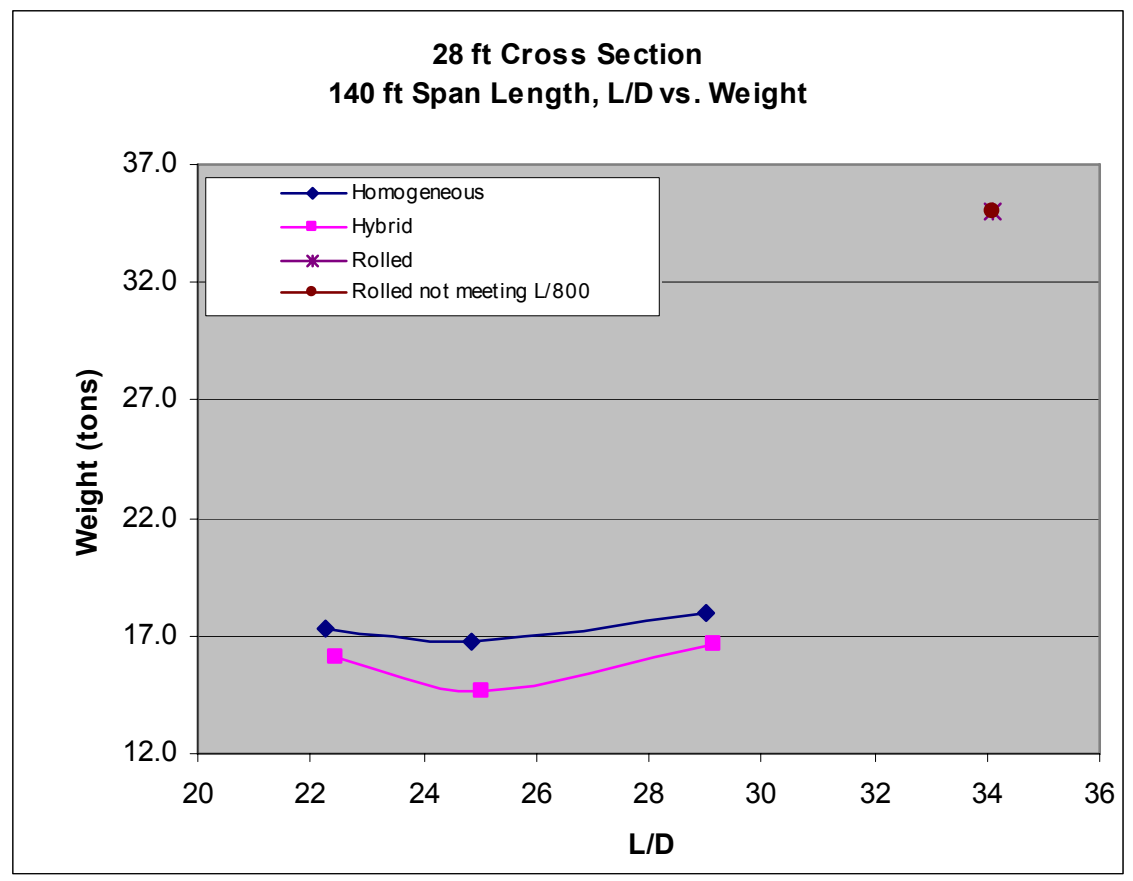

Figure 4.28 Weight Comparisons of Exterior Rolled Beam Designs

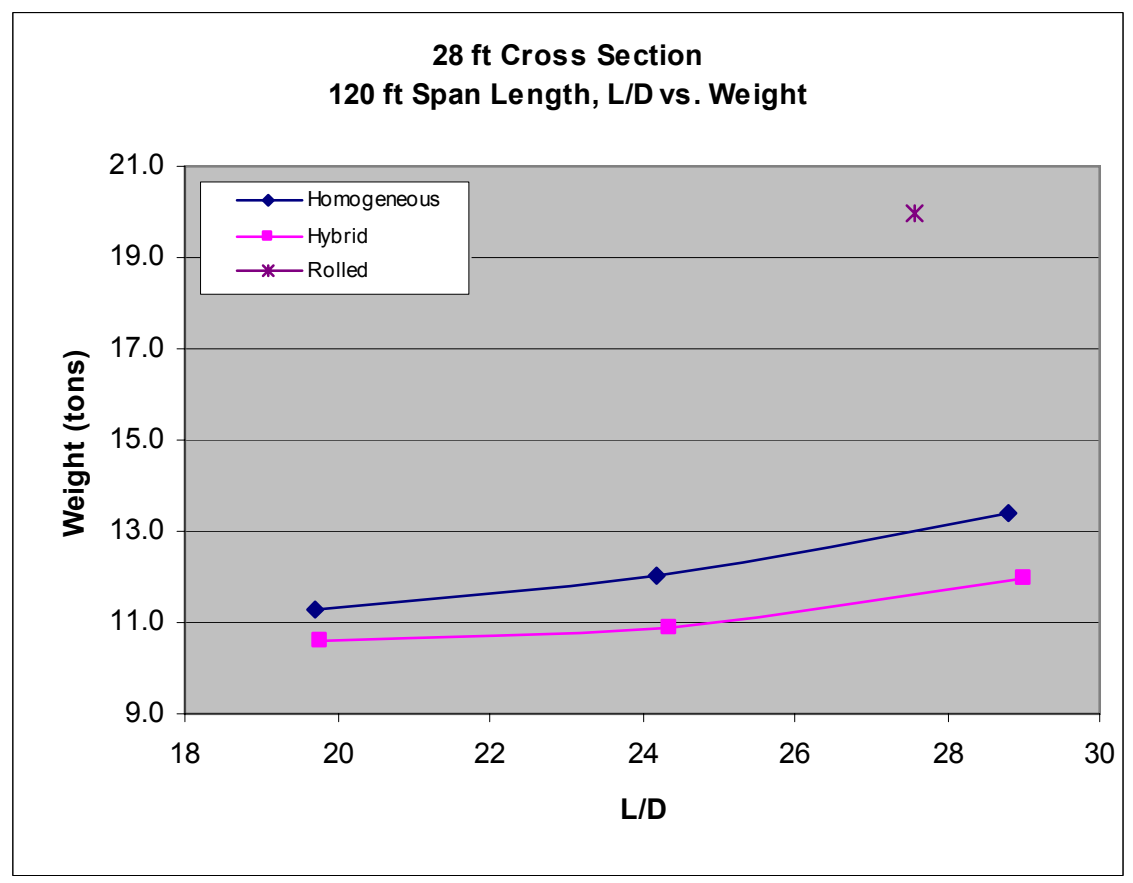

Figure 4.29 Weight Comparisons of Exterior Rolled Beam Designs 


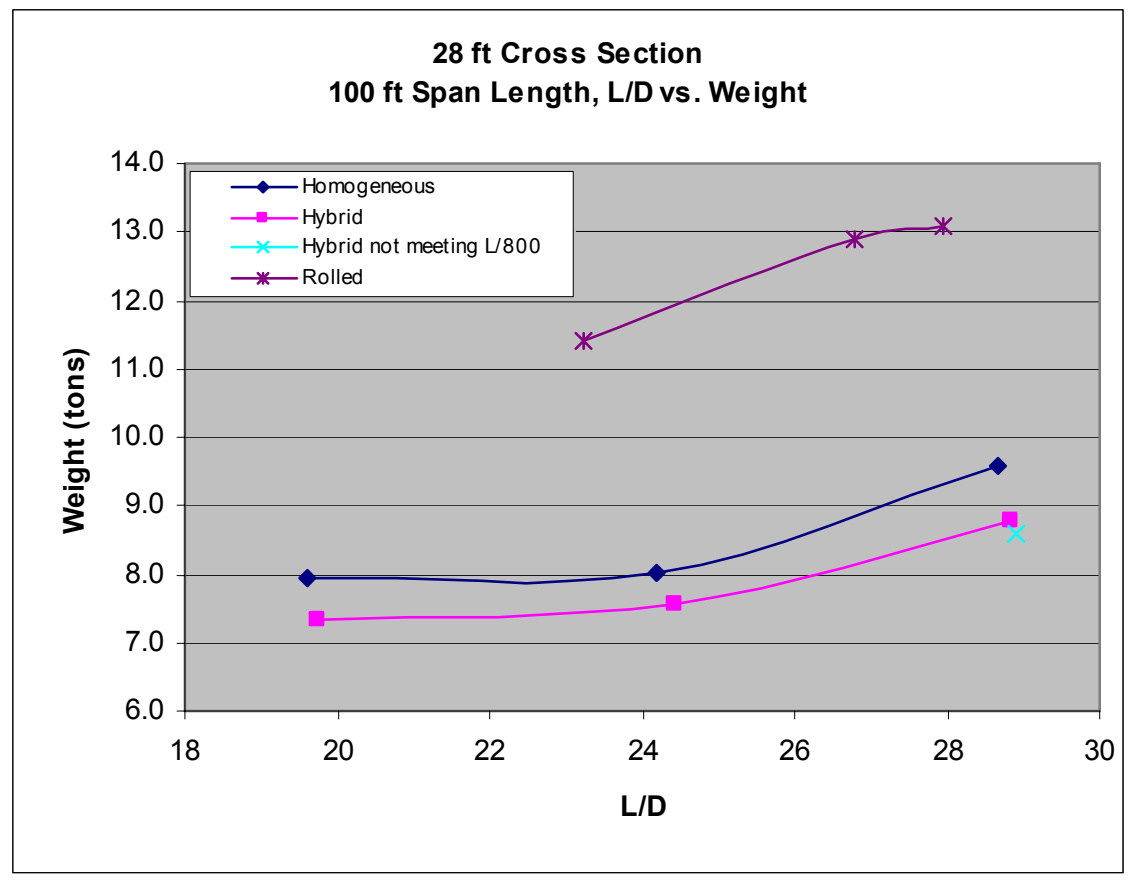

Figure 4.30 Weight Comparisons of Exterior Rolled Beam Designs

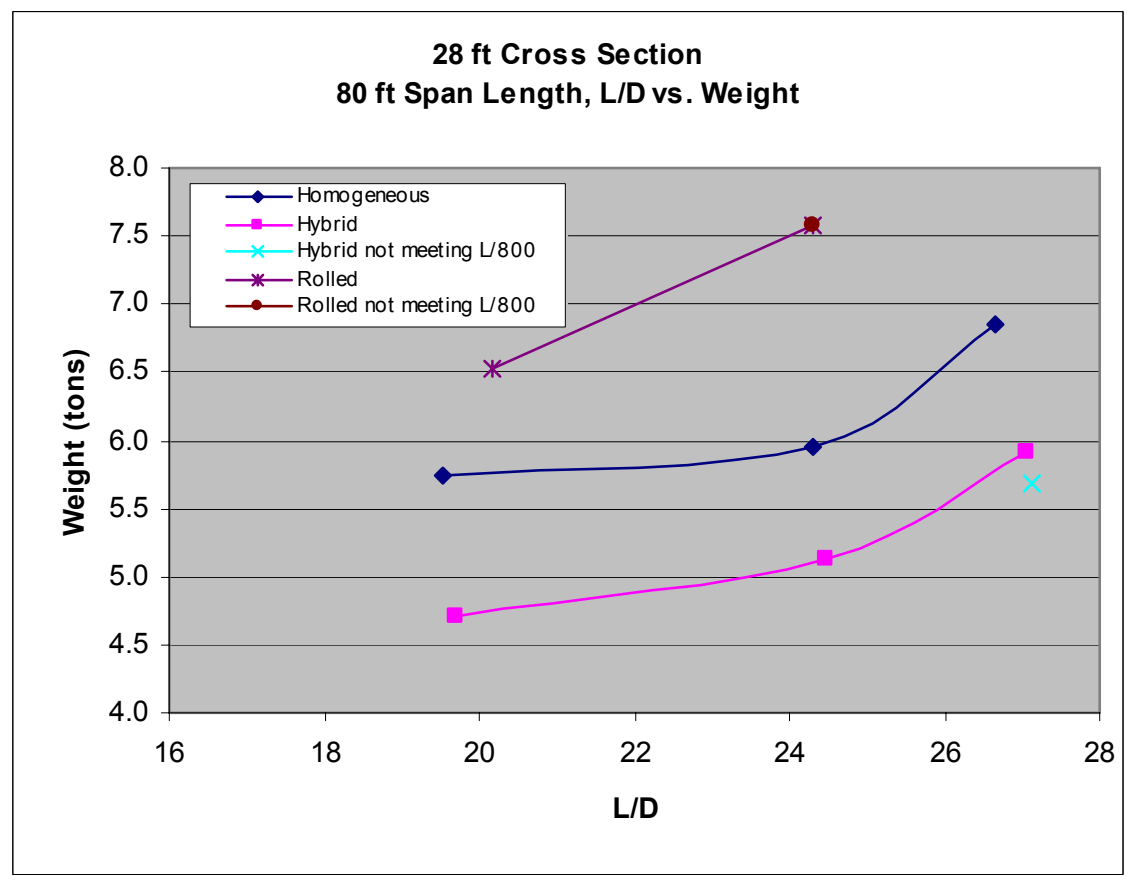

Figure 4.31 Weight Comparisons of Exterior Rolled Beam Designs 


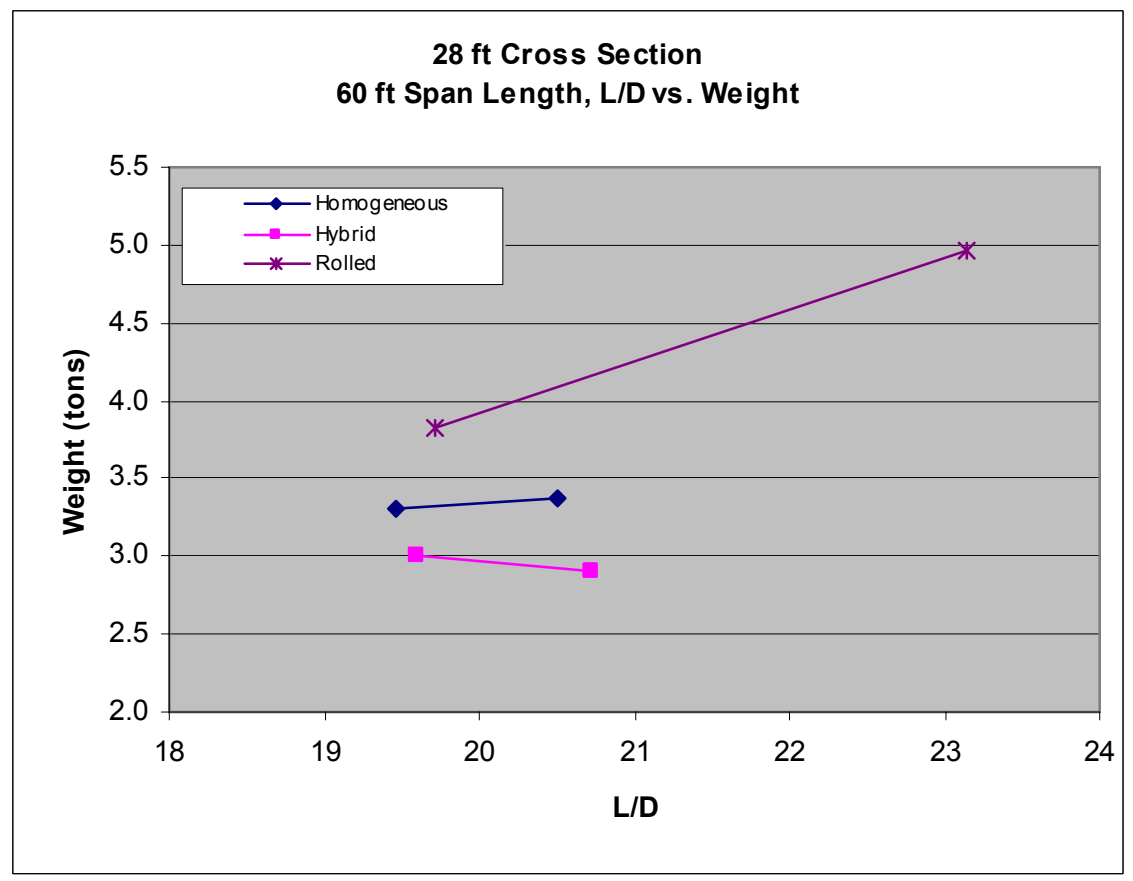

Figure 4.32 Weight Comparisons of Exterior Rolled Beam Designs

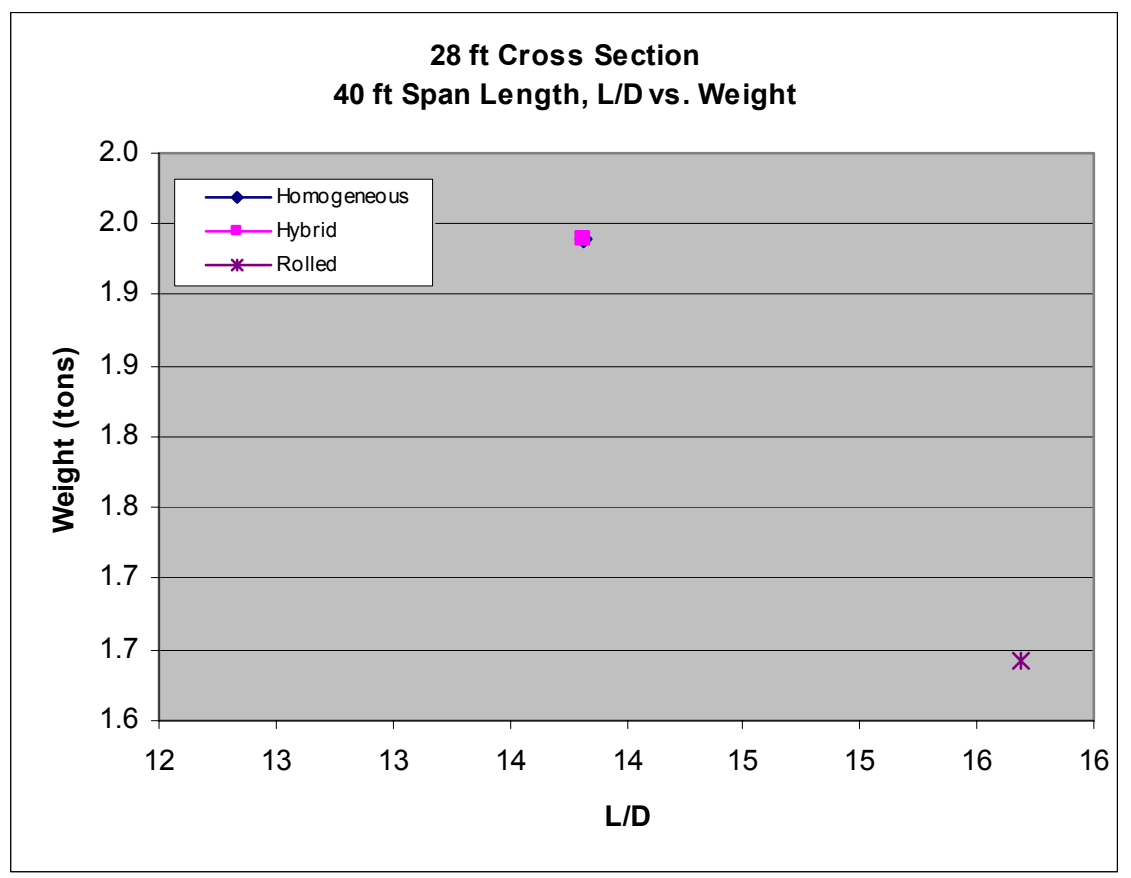

Figure 4.33 Weight Comparisons of Exterior Rolled Beam Designs 


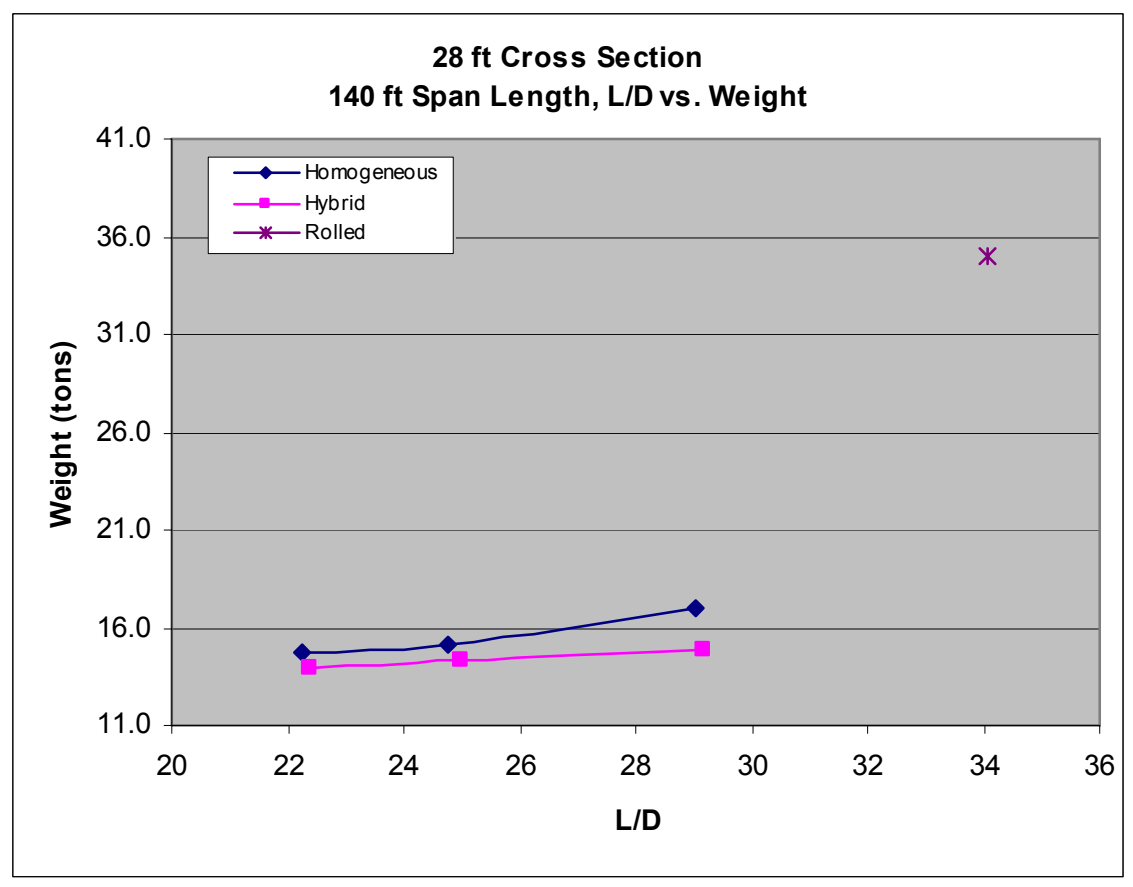

Figure 4.34 Weight Comparisons of Interior Rolled Beam Designs

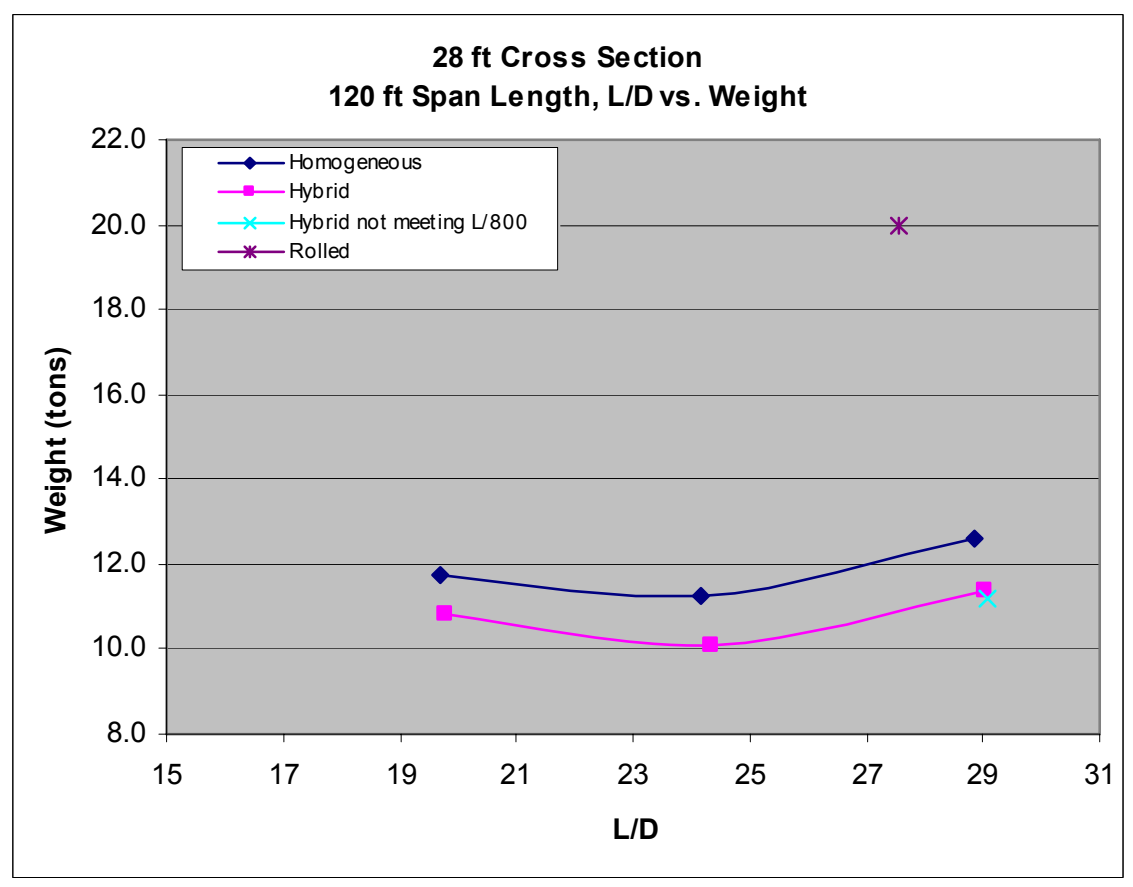

Figure 4.35 Weight Comparisons of Interior Rolled Beam Designs 


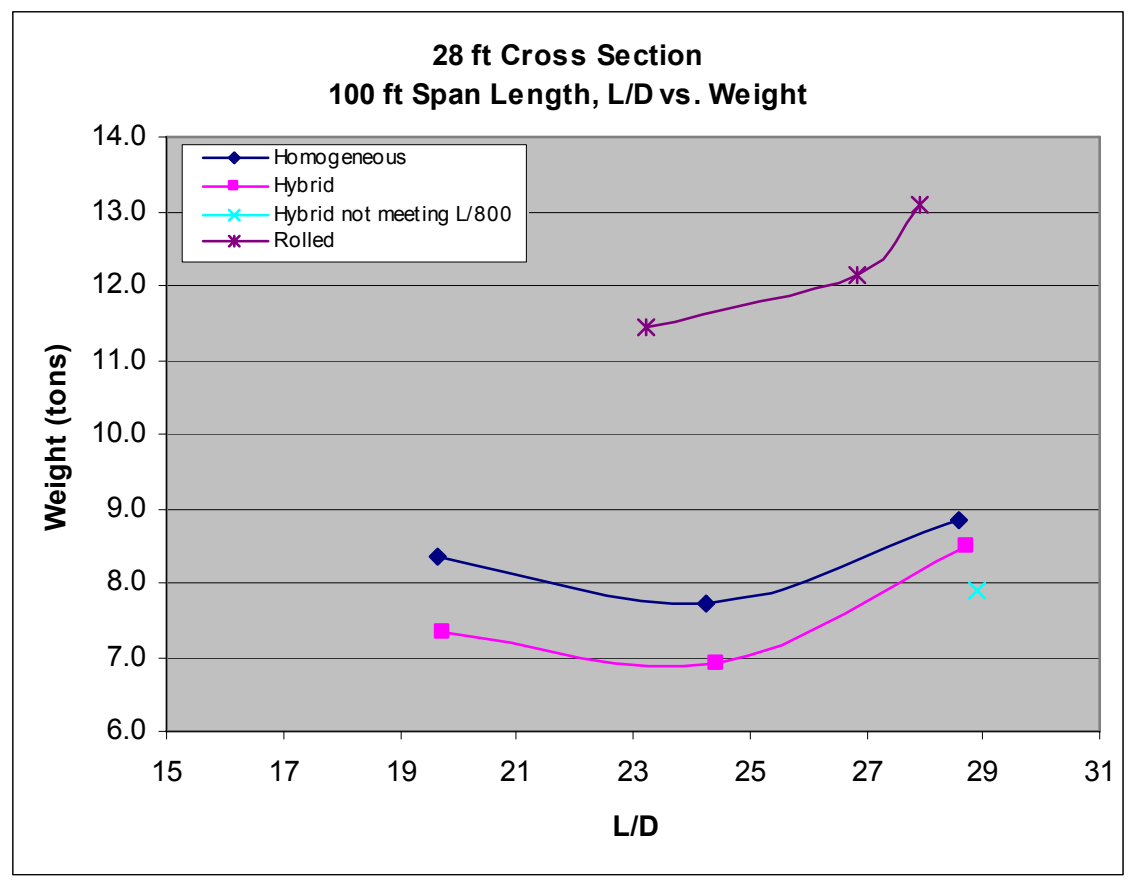

Figure 4.36 Weight Comparisons of Interior Rolled Beam Designs

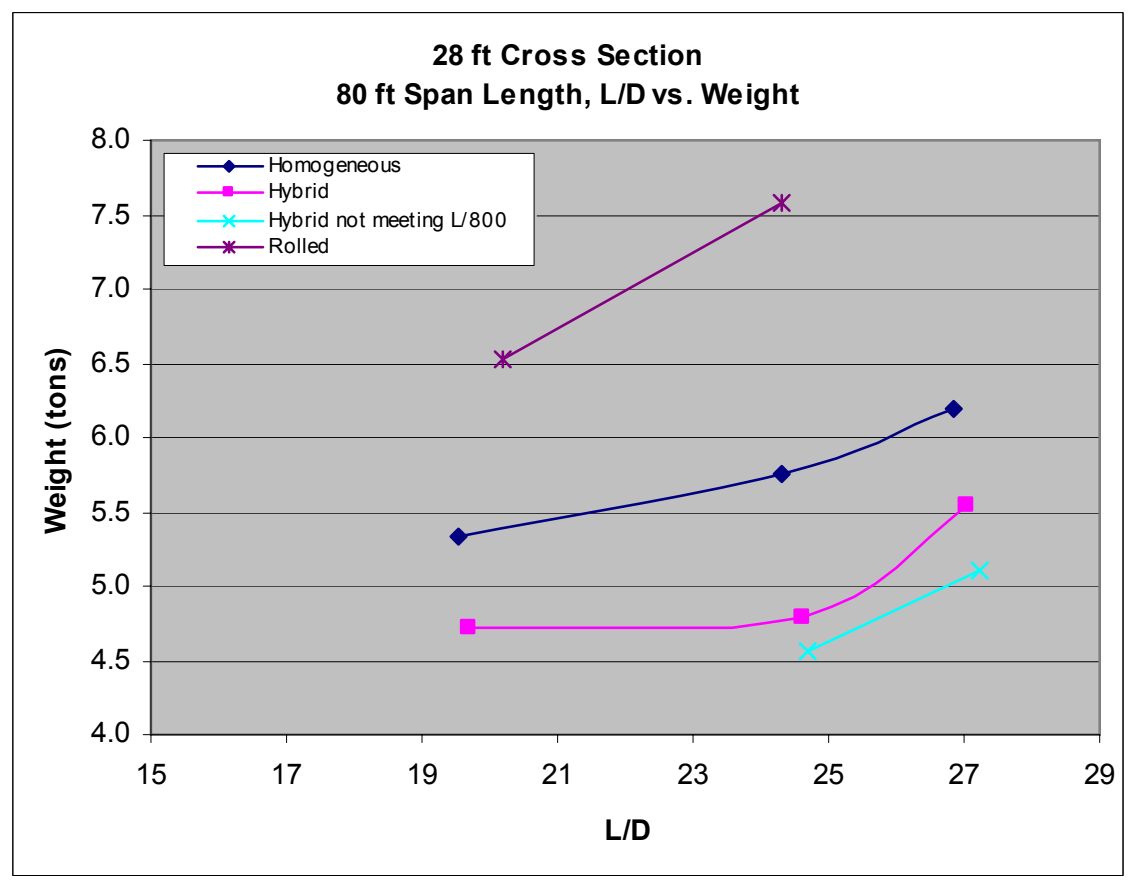

Figure 4.37 Weight Comparisons of Interior Rolled Beam Designs 


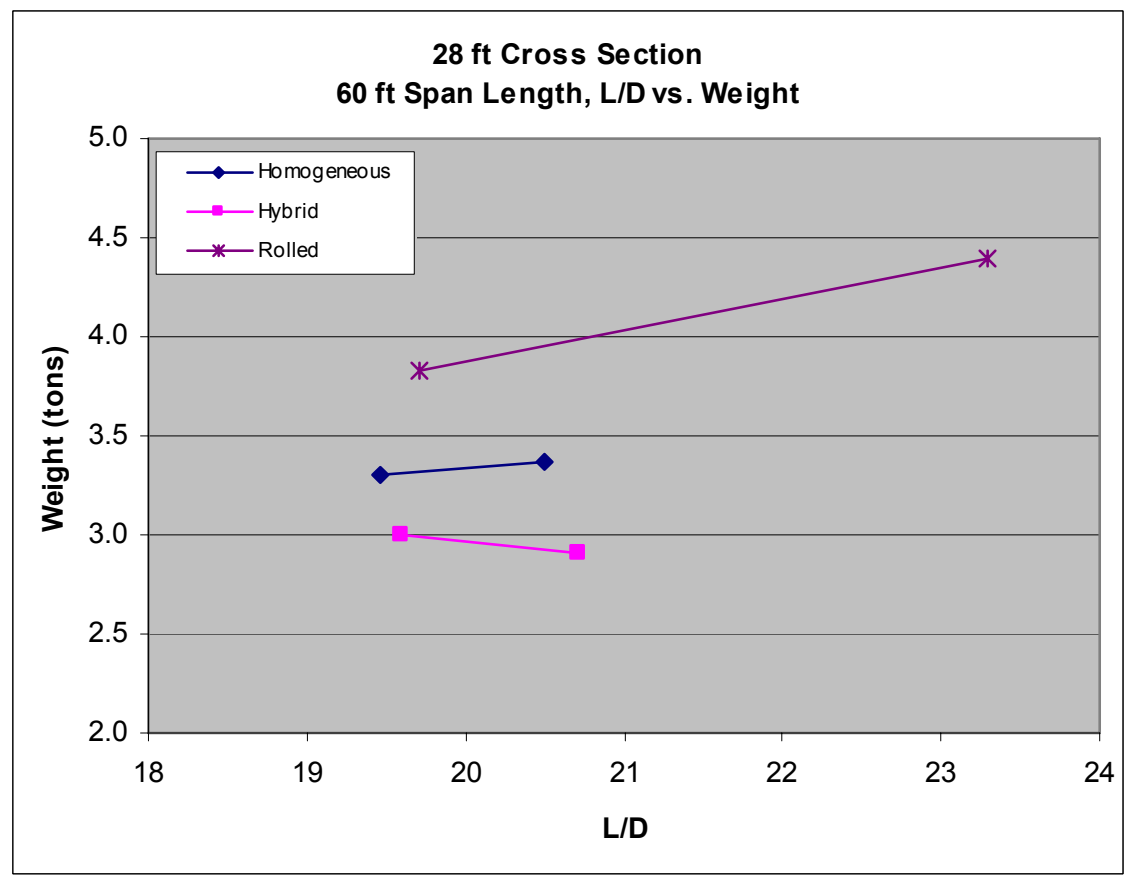

Figure 4.38 Weight Comparisons of Interior Rolled Beam Designs

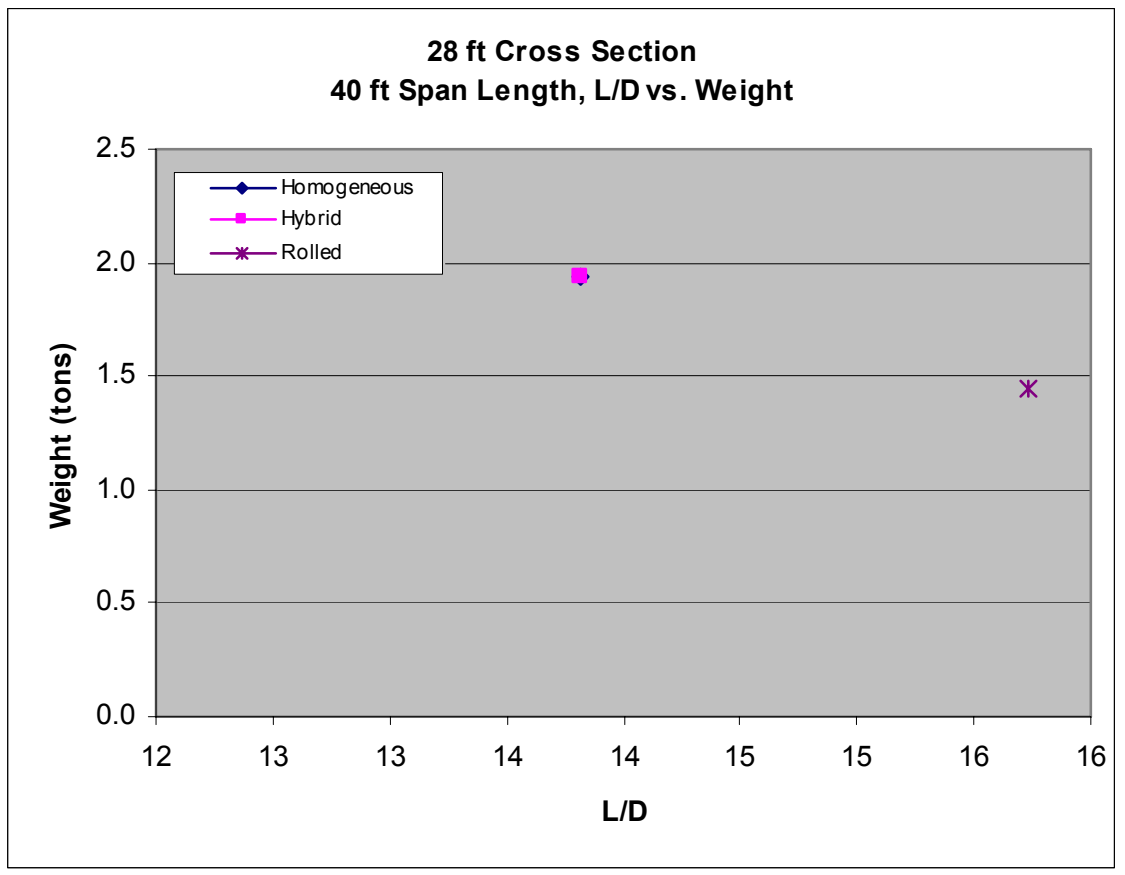

Figure 4.39 Weight Comparisons of Interior Rolled Beam Designs 


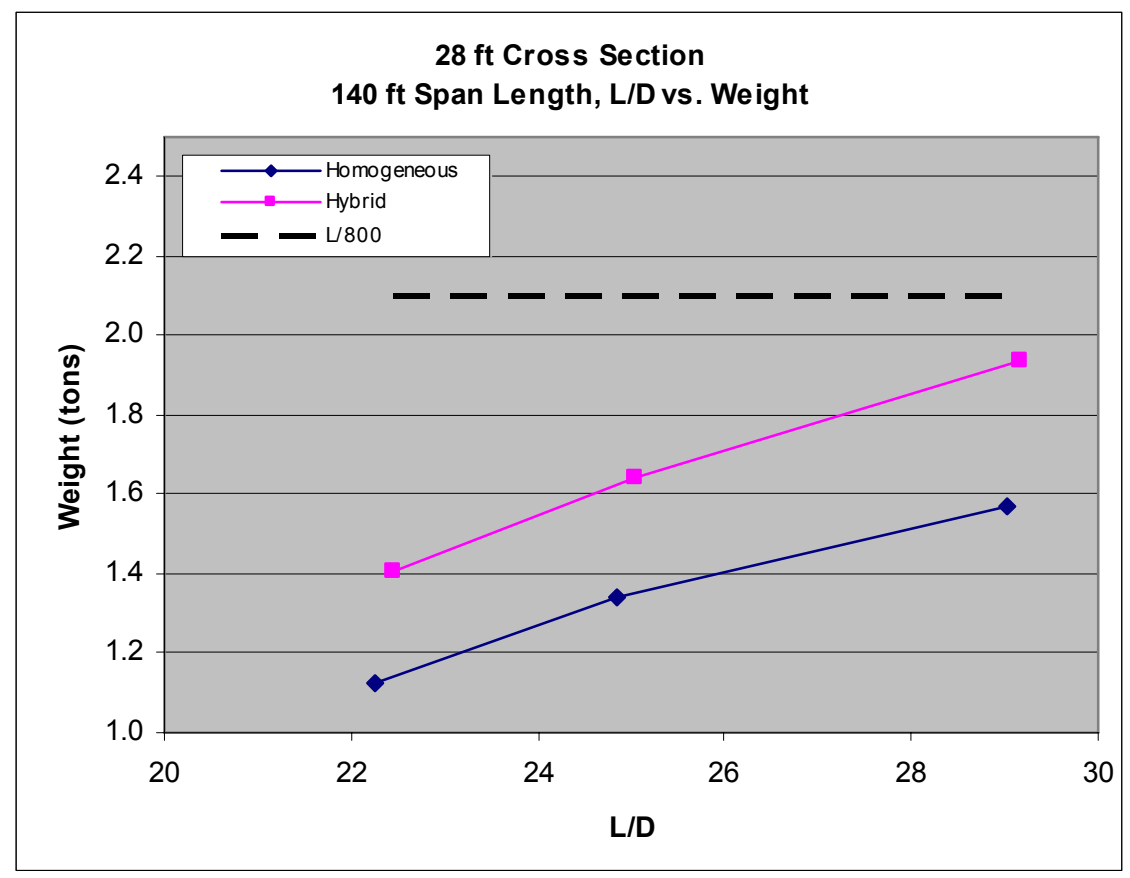

Figure 4.40 Deflection Comparisons for Exterior Girder Designs

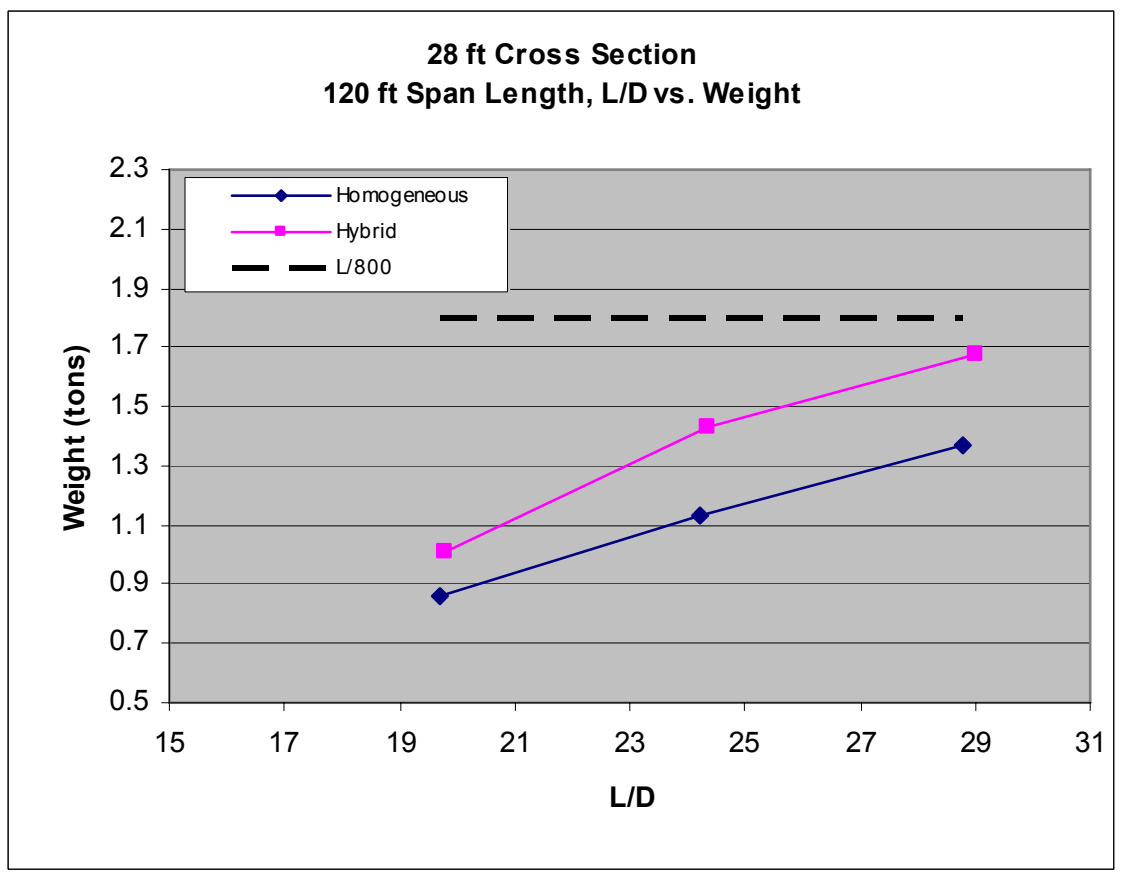

Figure 4.41 Deflection Comparisons for Exterior Girder Designs 


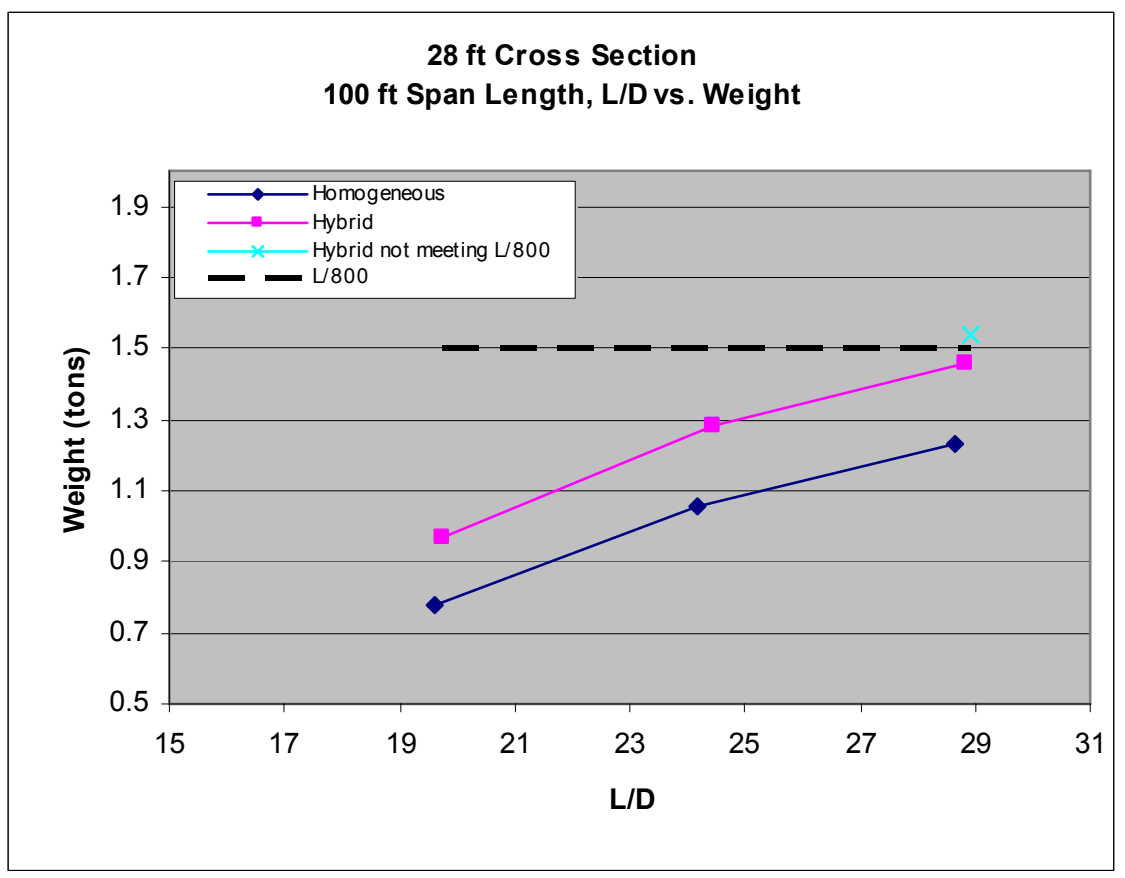

Figure 4.42 Deflection Comparisons for Exterior Girder Designs

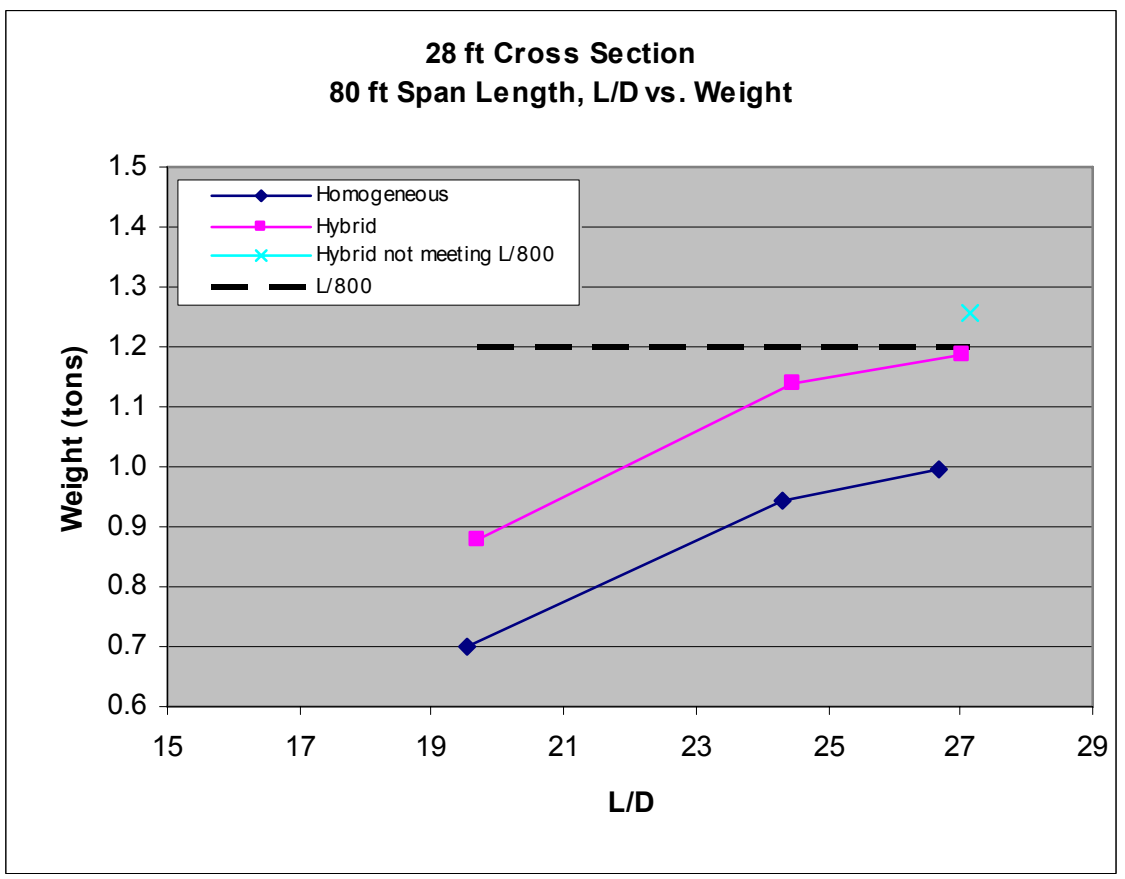

Figure 4.43 Deflection Comparisons for Exterior Girder Designs 


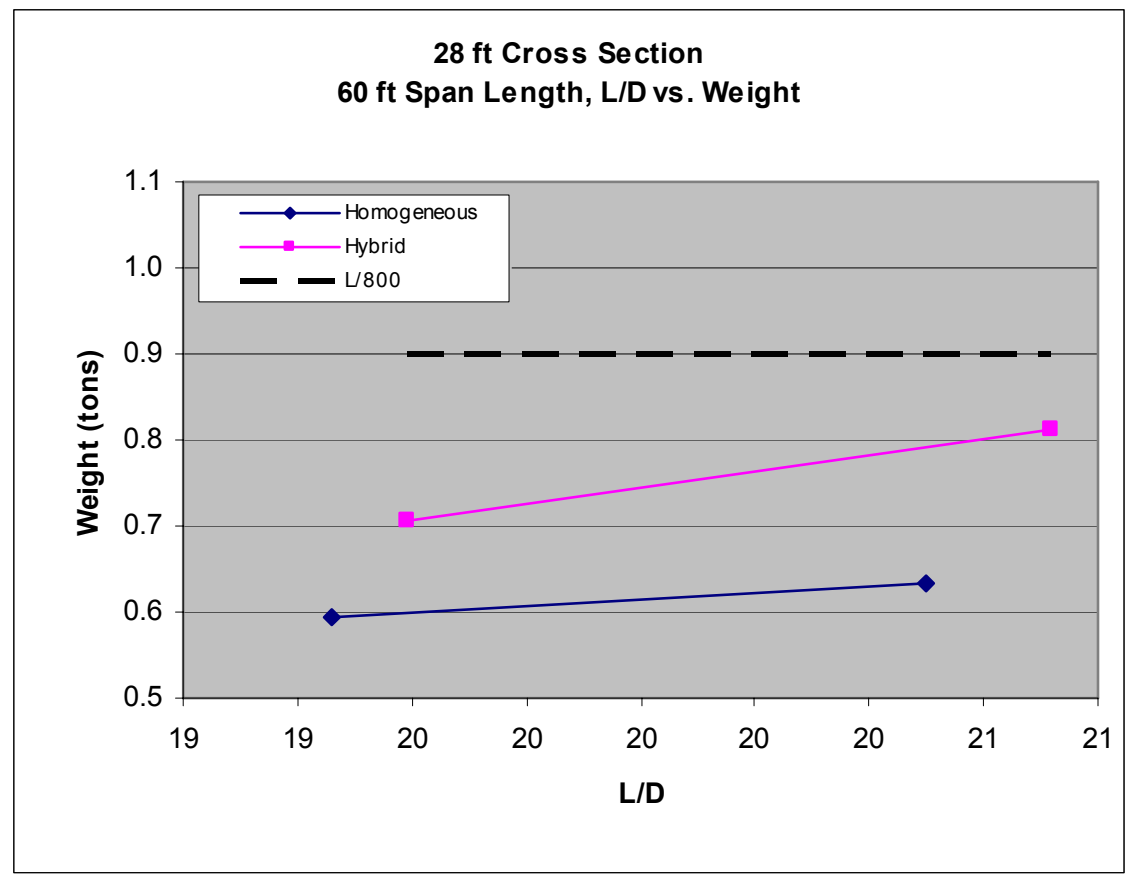

Figure 4.44 Deflection Comparisons for Exterior Girder Designs

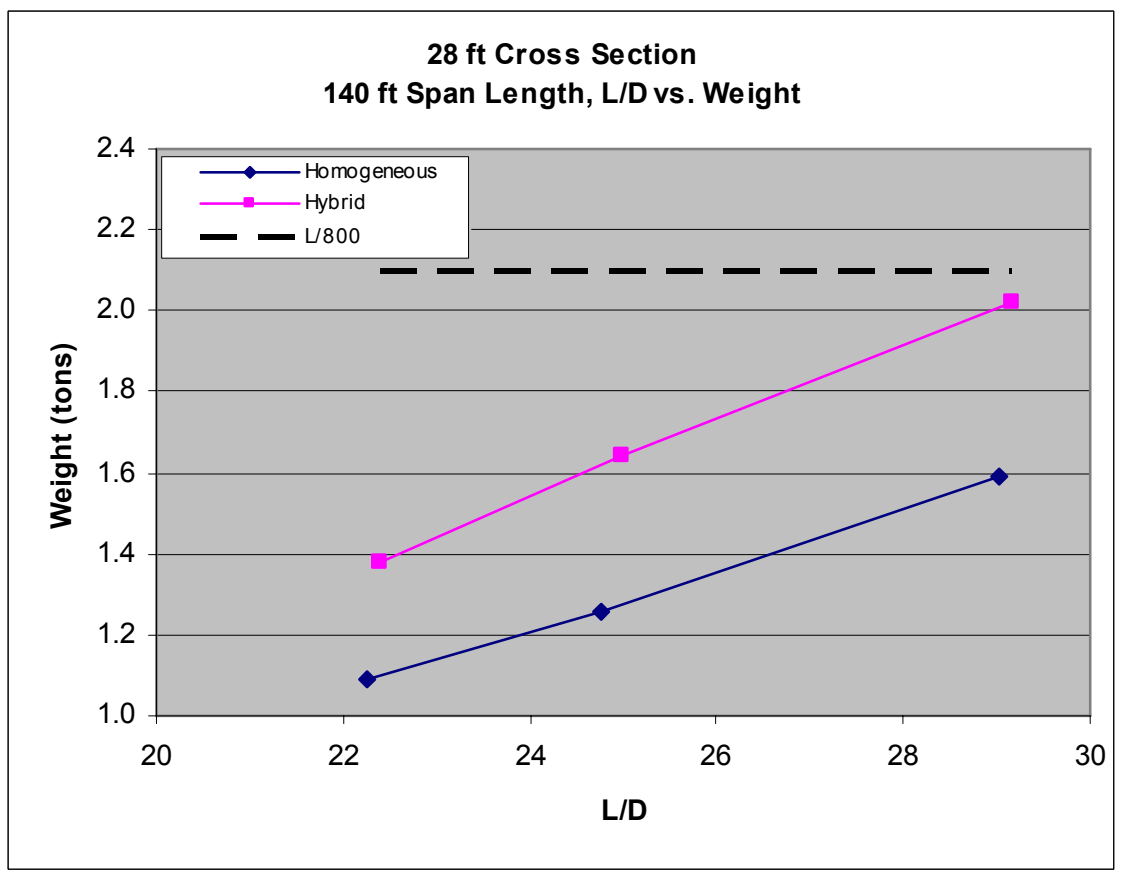

Figure 4.45 Deflection Comparisons for Interior Girder Designs 


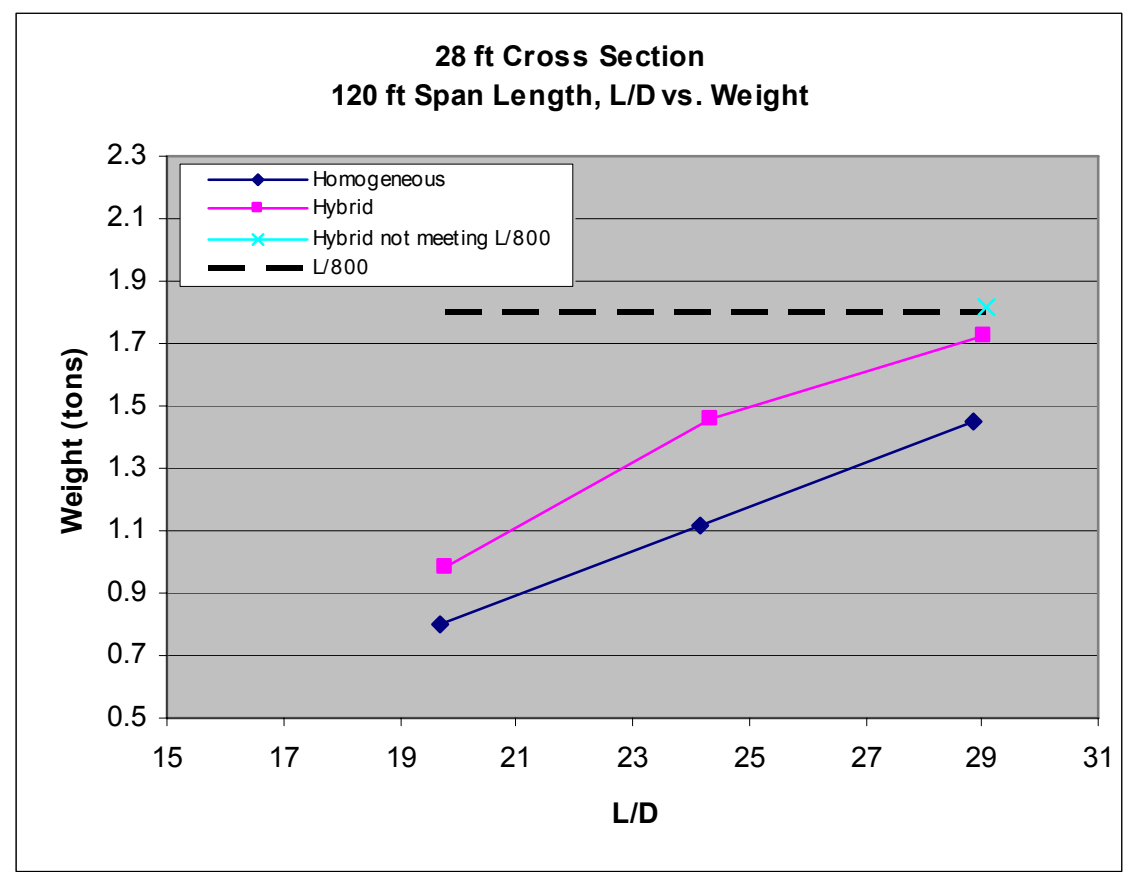

Figure 4.46 Deflection Comparisons for Interior Girder Designs

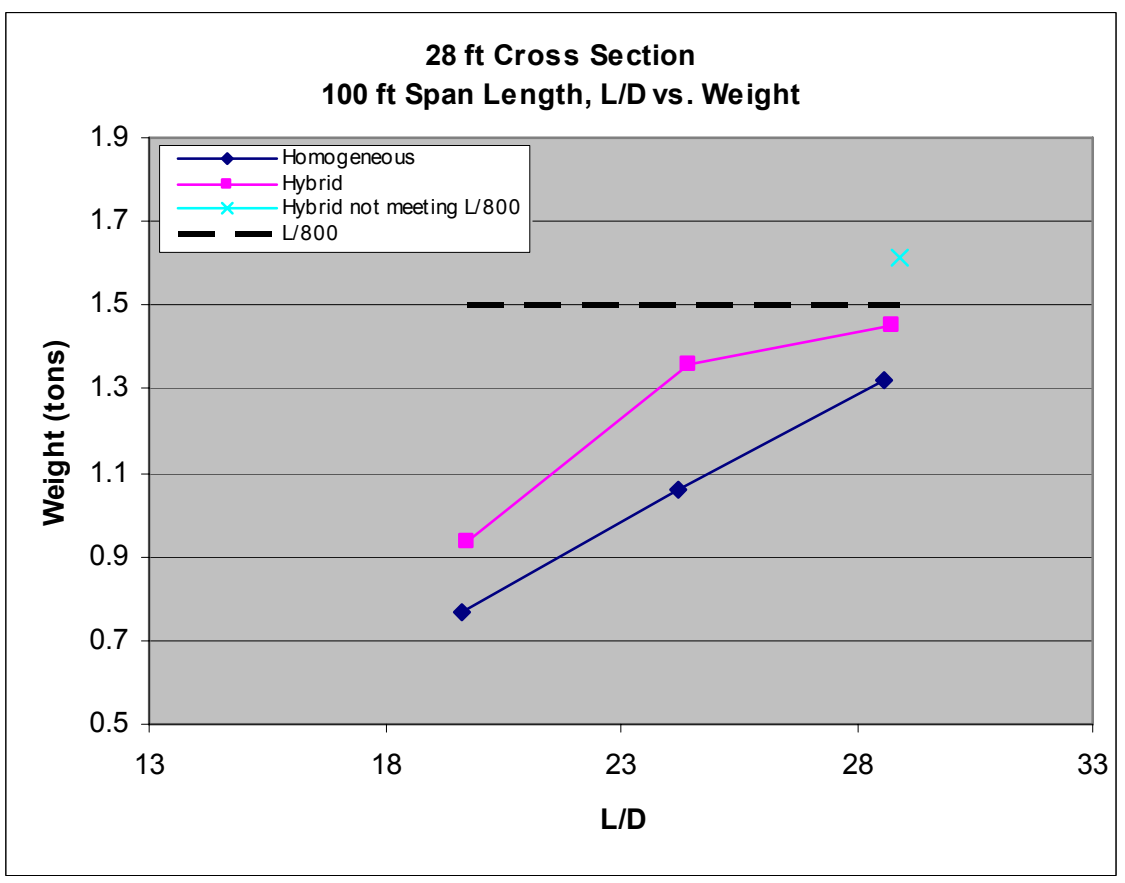

Figure 4.47 Deflection Comparisons for Interior Girder Designs 


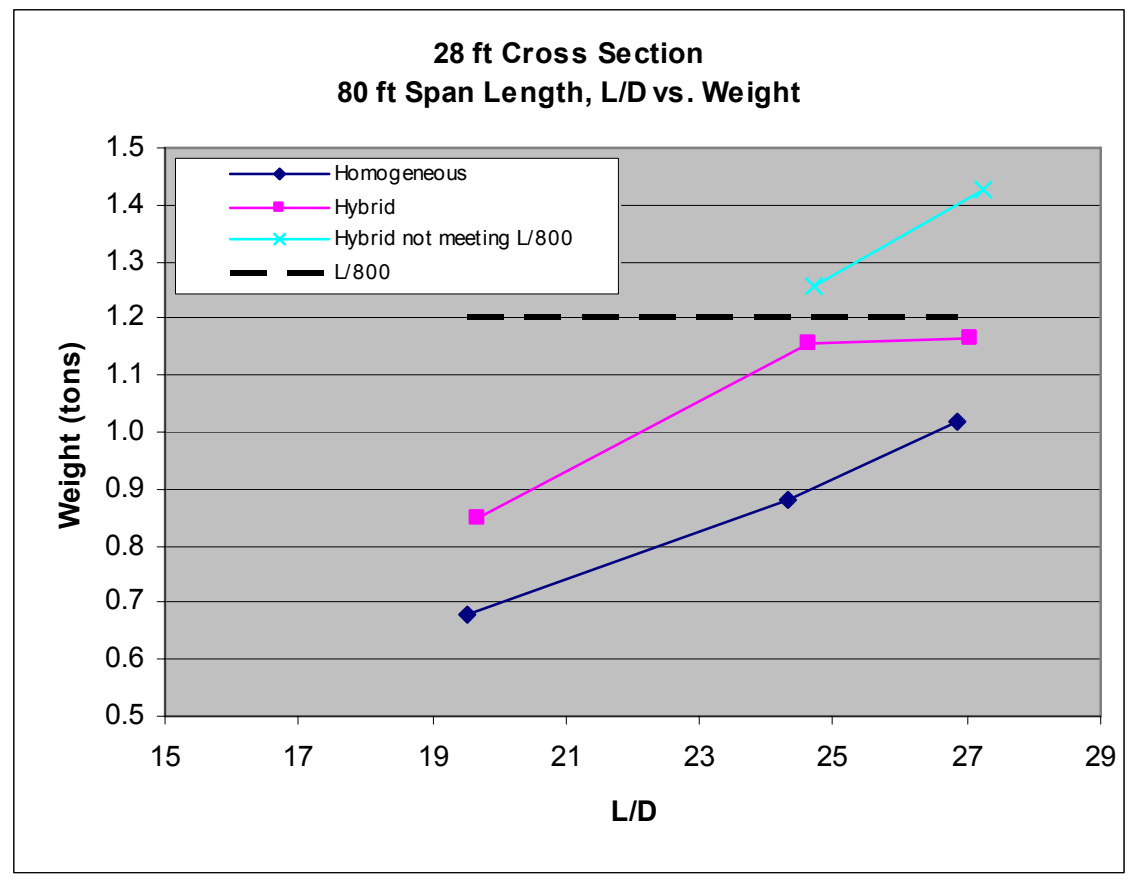

Figure 4.48 Deflection Comparisons for Interior Girder Designs

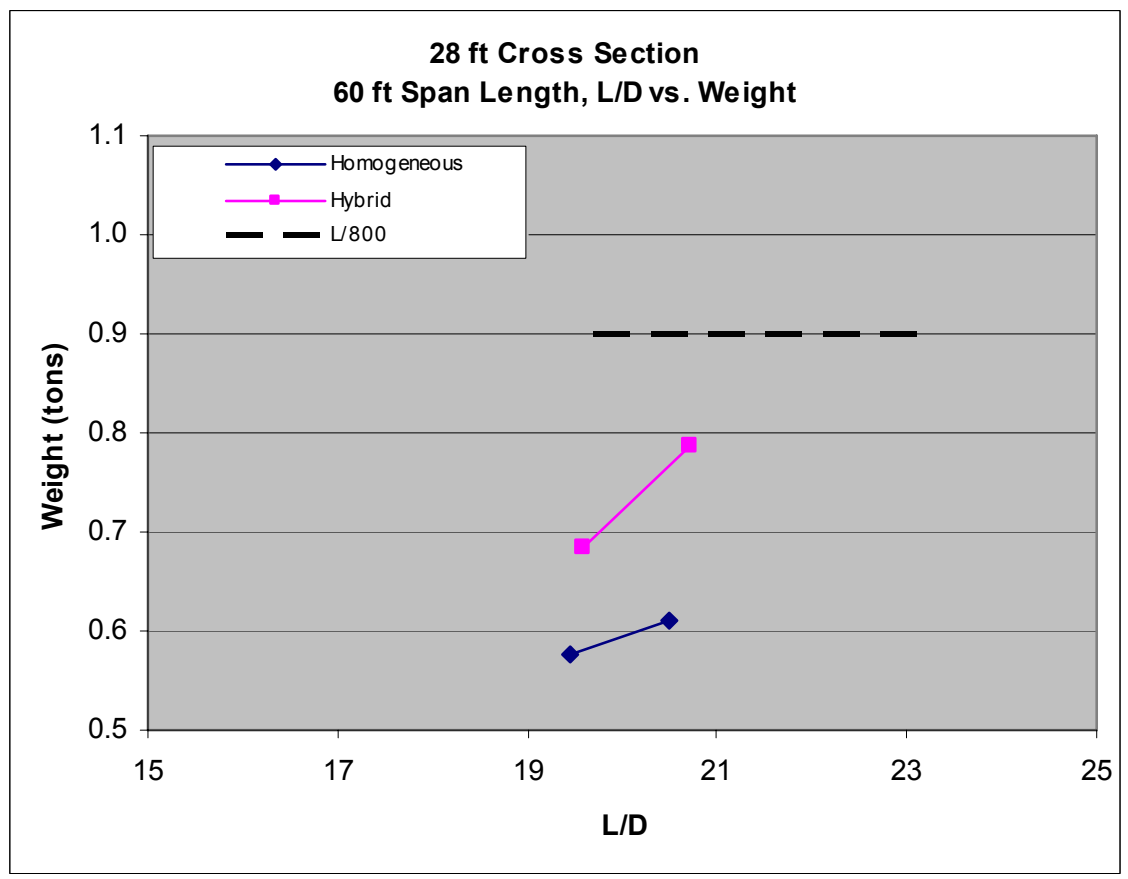

Figure 4.49 Deflection Comparisons for Interior Girder Designs 


\section{Chapter 5}

\section{Short-span Limited Plate Size Design Study}

\subsection{Introduction}

This chapter describes the design of short-span steel I-girders considering a limited number of plate sizes to investigate the economical effect of stockpiling more common plate sizes. Plates are more economical when purchased in bulk in widths of at least 48", therefore designs that require fewer plate transitions might reduce the overall cost of the bridge. This chapter discusses the effort that limits the available plate sizes and flange transitions used in this design package to investigate the possibility, that savings might be realized even though the sections may require slightly more steel.

\subsection{Assumptions and Plate Sizes}

In this study, composite steel I-girders consisting of limited plate sizes were designed for two cross sections with span lengths ranging from 40 to 140 feet in 5 feet increments. The typical girder elevation is similar to the ones used in the optimized study with the exception of flange transitions, which was omitted to evaluate the above mentioned design alternatives. Homogeneous and hybrid girders were evaluated, similar to the optimized designs, where homogeneous plate girders consist of a $50 \mathrm{ksi}$ steel, and hybrid plate configurations have a $70 \mathrm{ksi}$ tension flange and $50 \mathrm{ksi}$ compression flange and web. A typical girder elevation is shown in Figure 5.1, with the exception of flange 
transitions and transverse stiffeners at locations $\mathrm{x}, \mathrm{y}$ and $\mathrm{z}$, since these girders were designed with un-stiffened webs. The available plate thicknesses were limited to the more common plate sizes of $1 / 2 ", 3 / 4 ", 1 ”, 1 \frac{11 / 2}{}, 13 / 4 "$ and $2 "$. Only four web depths were employed during this design process; these are 24", 32", 40" or 48". Similar to the optimized designs, the web depth was selected from the target span-to-depth ratios by subtracting the slab thickness, haunch and the bottom flange thickness. Since only limited plate sizes were allowed for web depths, span-to-depth ratios vary as a function of available plate selections. Span lengths 75 feet to 120 accommodated for two target spanto-depth ratios, while all the other span lengths allowed one limited plate size design.

The design criteria remained the same as for the optimized girder study discussed in section 4.2. This includes first selecting the appropriate web height using the limited web plate options and the target span-to-depth ratios. Since limited plates were only available to select from, the nearest web height was picked from the computed span-todepth ratios. The initial flange width was selected so that the web-depth-to-compressionflange-width ratio falls between 3.0 and 4.0. The design capacity of the initial section was computed using the excel spreadsheet discussed in section 4.3 and extracting moment and shear envelopes from Consys 2000. Once the initial cross section was developed, the capacity of the girder was checked and necessary revision to the steel section was made. The iterative process was continued until the lightest cross section was developed using the limited plate sizes. 
The designs were completed initially neglecting the optional live-load deflection criteria, followed by the same web depth designs to satisfy the limit. Similar to the optimized design study, minimum plate restrictions were employed which set the minimum flange size to be $12 " \times 3 / 4$ ". The girders were developed in this study to satisfy the strength, service, construction and fatigue limit states according to the $3^{\text {rd }}$ Edition of the AASHTO LRFD Bridge Design specifications.

\subsection{Designs and Results}

A summary of the limited plate size designs for the 28 feet and 34 feet cross section are presented in Appendix A. Figures 5.1 through 5.3 details the typical girder elevation and the two cross sections.

\subsubsection{Weight Comparison}

This study revealed that limited plate size designs are not significantly heavier than the optimized designs, as it is shown in Figures 5.4 through 5.8. As span length decreases limited design girder weight approach optimized section weight since shorter span length are controlled by minimum plate restrictions. For exterior designs, homogeneous configurations were $10.0 \%$ heavier than the ones from the optimized design study, while for hybrid designs the difference is approximately $5.5 \%$. Interior design weight differences show similar patterns when compared to the optimized designs. 


\subsubsection{Influence of Material Configuration}

On average, within the limited plate sizes hybrid configurations were found to be closer to the optimized girder weight. As previously mentioned, the limited plate designs are on average $10.0 \%$ heavier for homogeneous sections and $5.5 \%$ heavier for hybrid sections than the optimized girders. When compared the influence of material configuration among the limited plate size designs, hybrid sections are lighter than homogeneous sections. For exterior girder designs, hybrid sections are $12.5 \%$ lighter than homogeneous girders, while for interior designs the difference is $9.0 \%$. This is a result of the hybrid sections requiring the tension flange to be less than the homogeneous girders. Since the plate thicknesses are only available in larger increments, $50 \mathrm{ksi}$ configurations will produce in significantly heavier sections.

\subsubsection{Influence of Live-load Deflection}

In general, limited plate size designs are more likely to satisfy the optional liveload deflection limit. Figures 5.9 through 5.14 show the comparisons between optimized and limited designs as deflection versus span-to-depth ratios are plotted. Only four of all the limited designs did not satisfy the optional live-load deflection criteria, all of them being hybrid girder configuration. Limited plate size designs failed the L/800 deflection criteria by an extremely small amount of 0.04 in. 


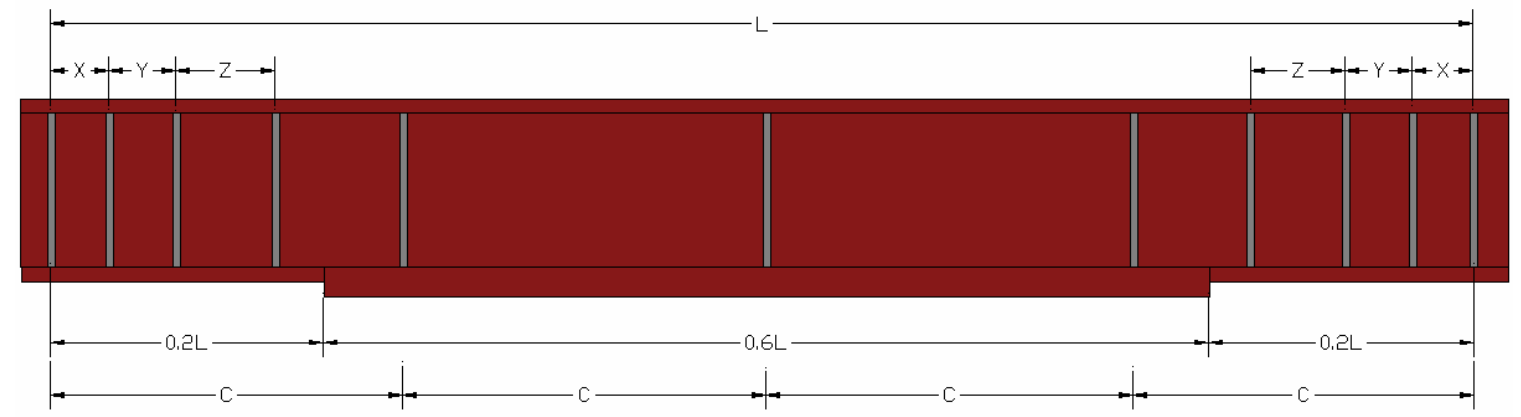

Figure 5.1 Typical Girder Elevation

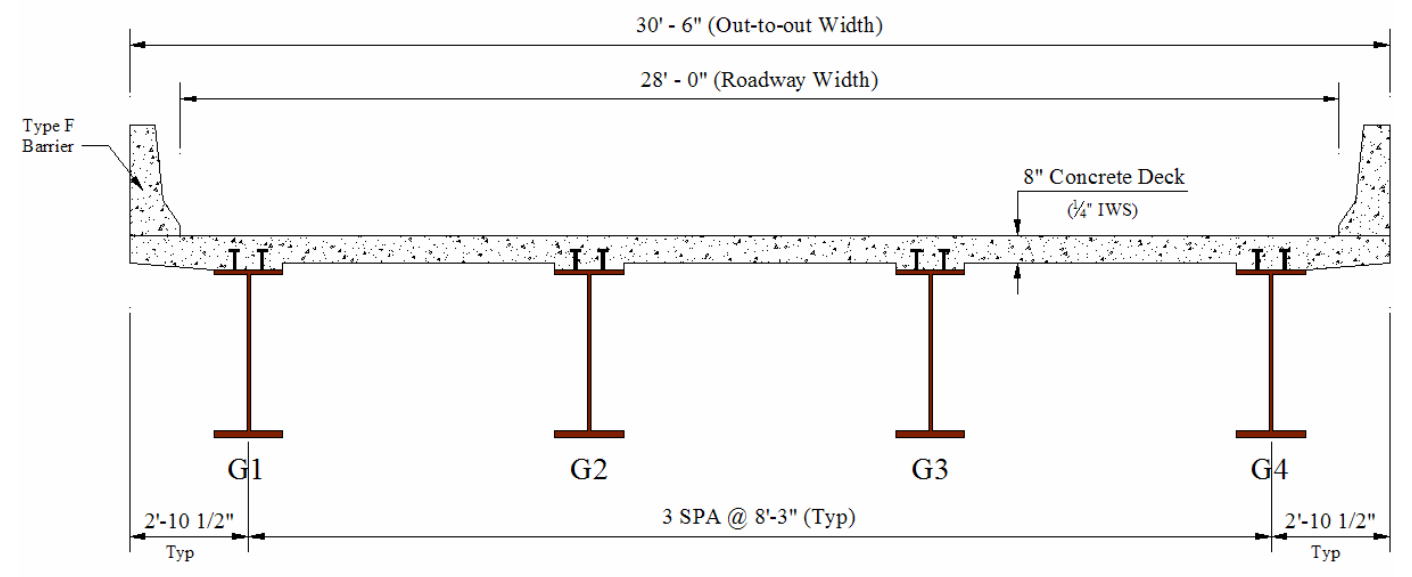

Figure 5.2 Bride Cross-section with 28-ft. Clear Roadway Width

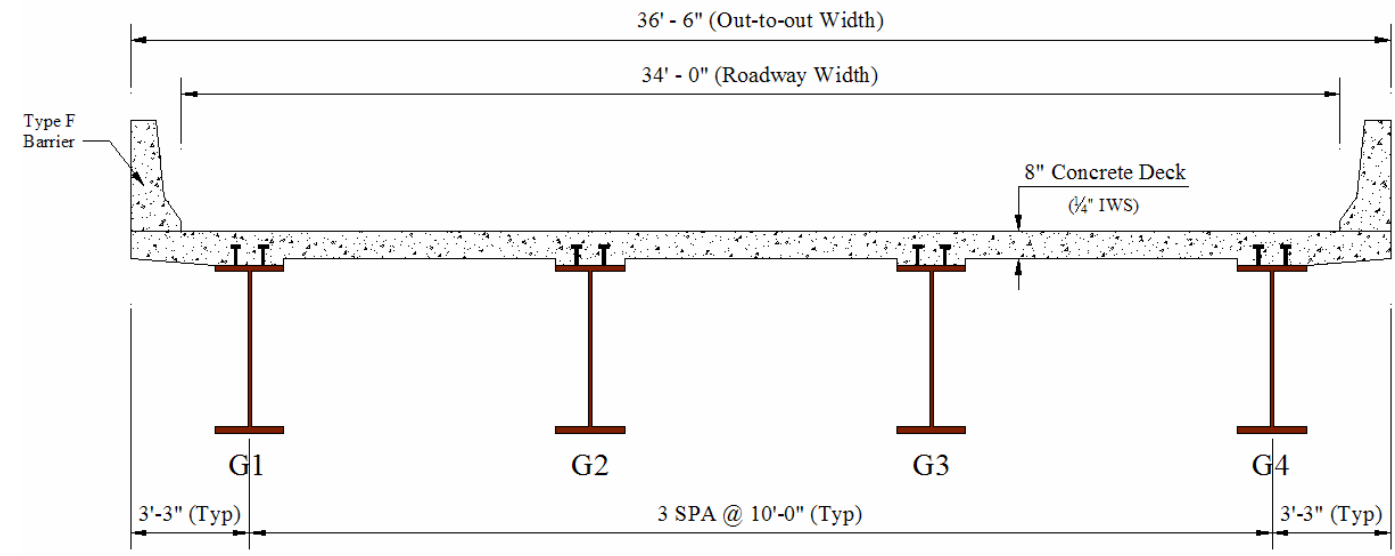

Figure 5.3 Bride Cross-section with 34-ft. Clear Roadway Width 


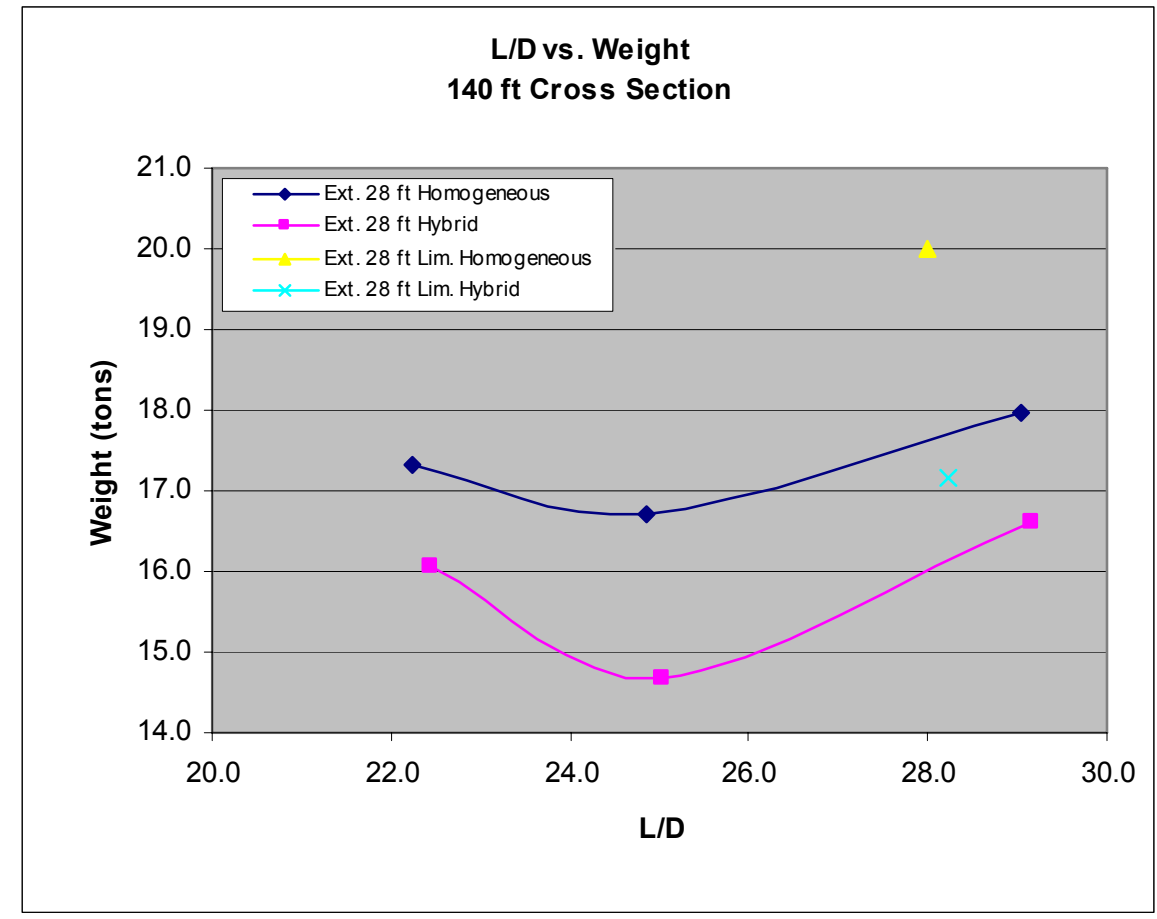

Figure 5.4 Limited Plate Designs

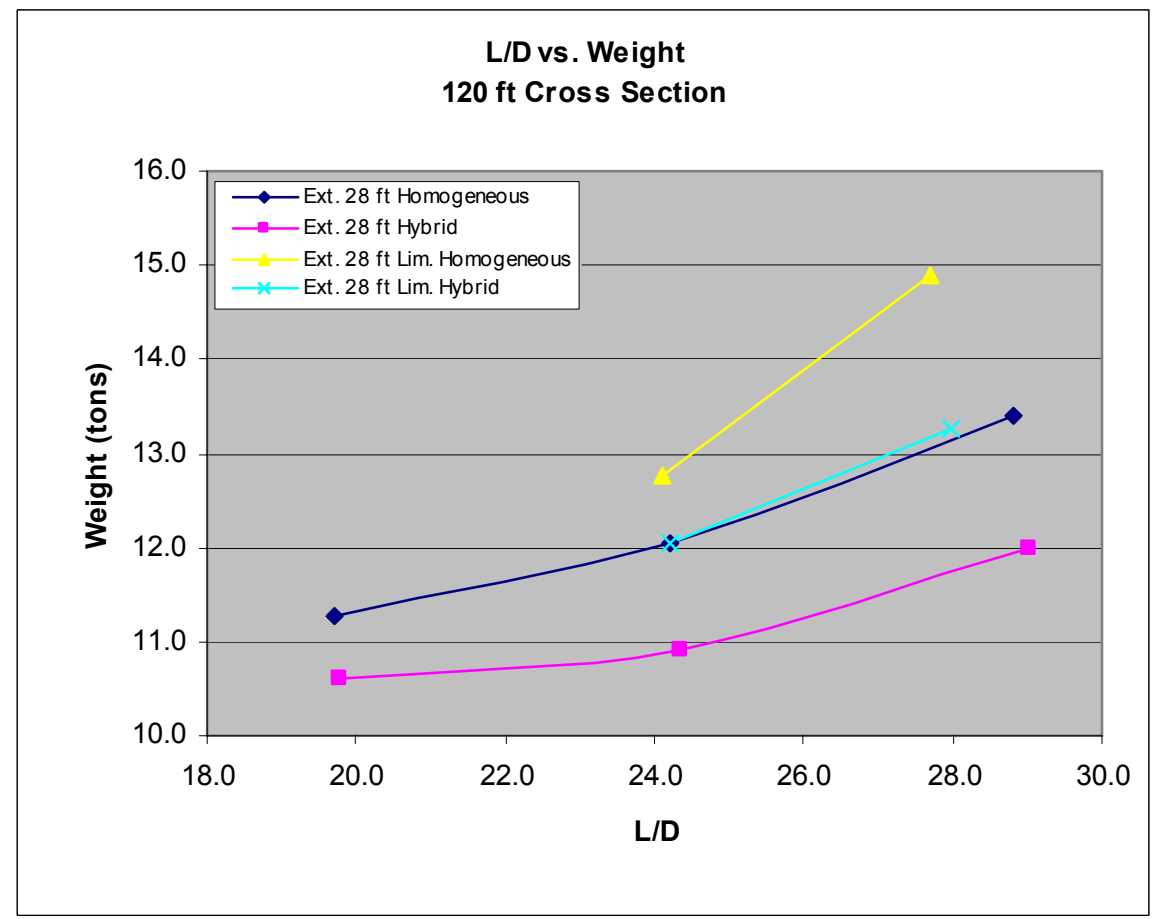

Figure 5.5 Limited Plate Designs 


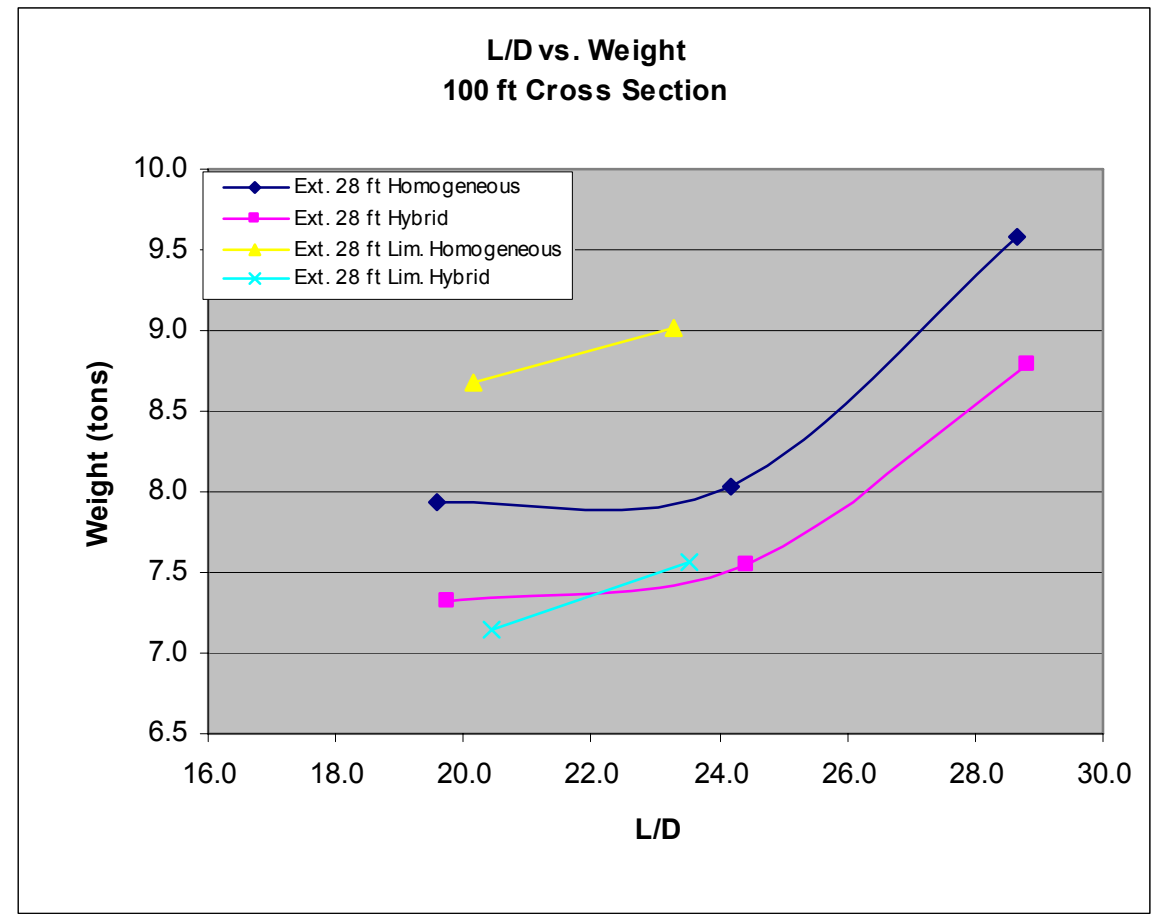

Figure 5.6 Limited Plate Designs

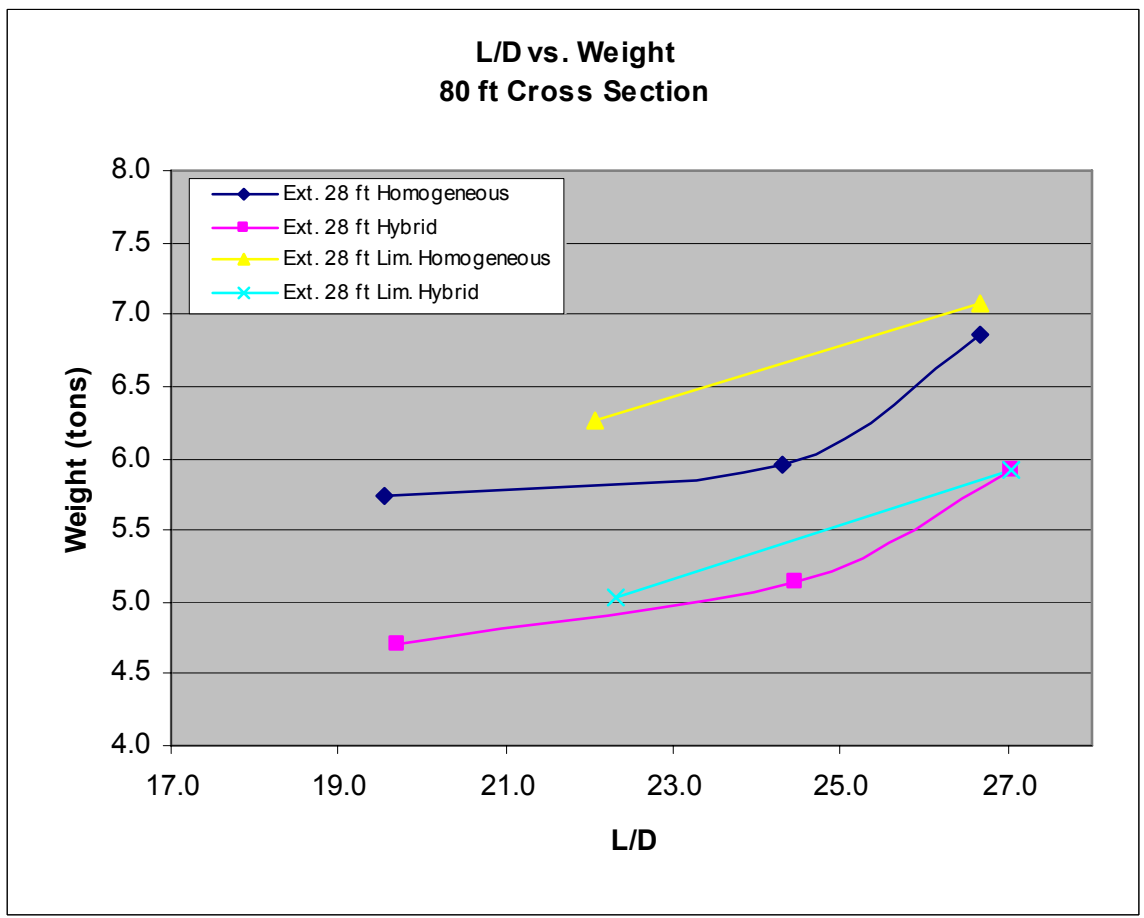

Figure 5.7 Limited Plate Designs 


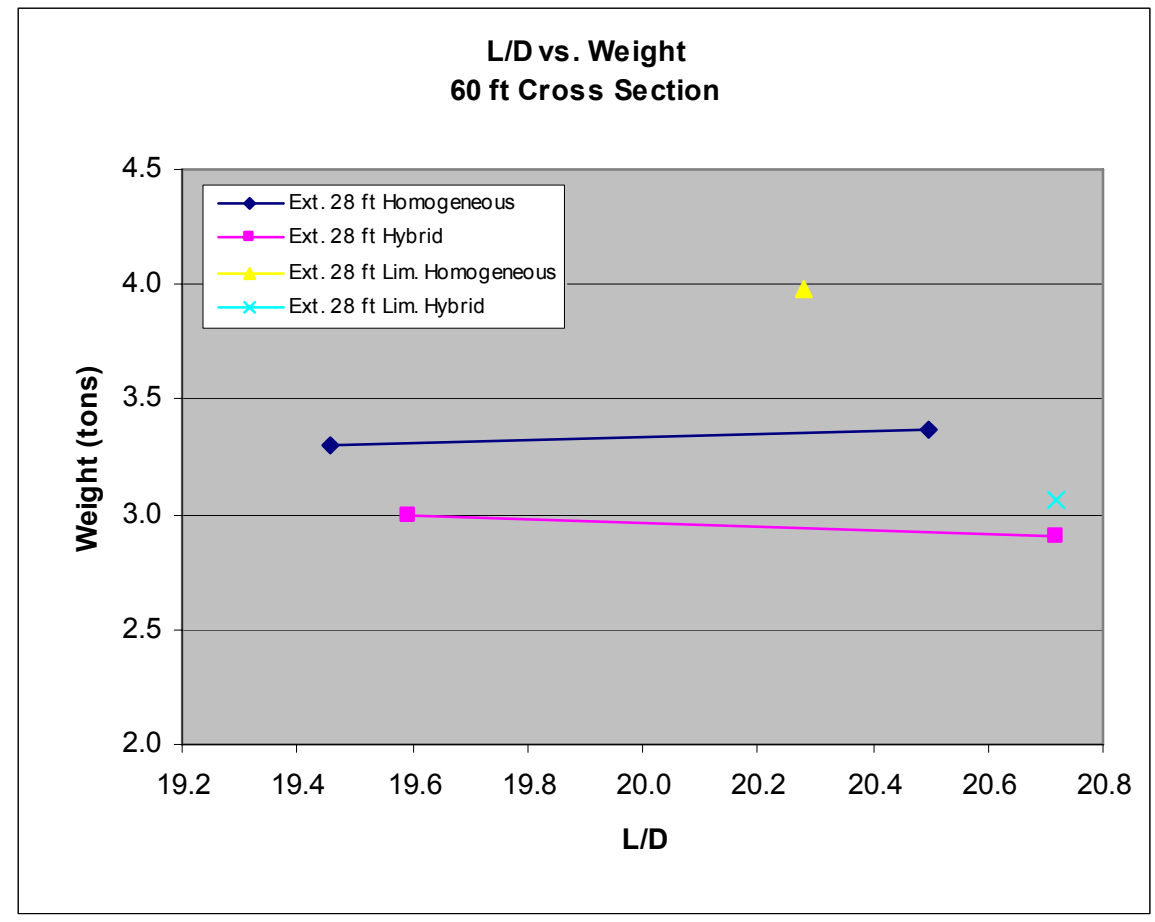

Figure 5.8 Limited Plate Designs

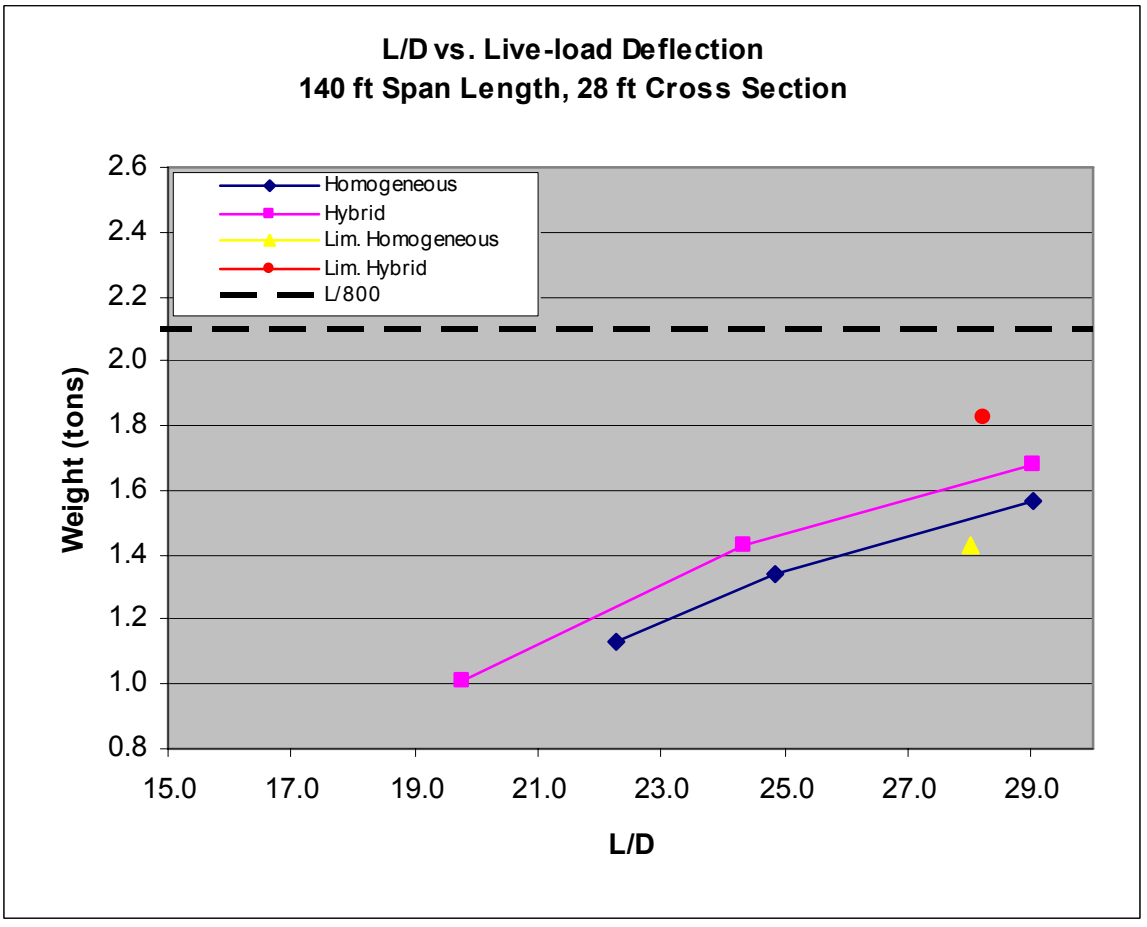

Figure 5.9 Limited Plate Design Deflection for Exterior Girders 


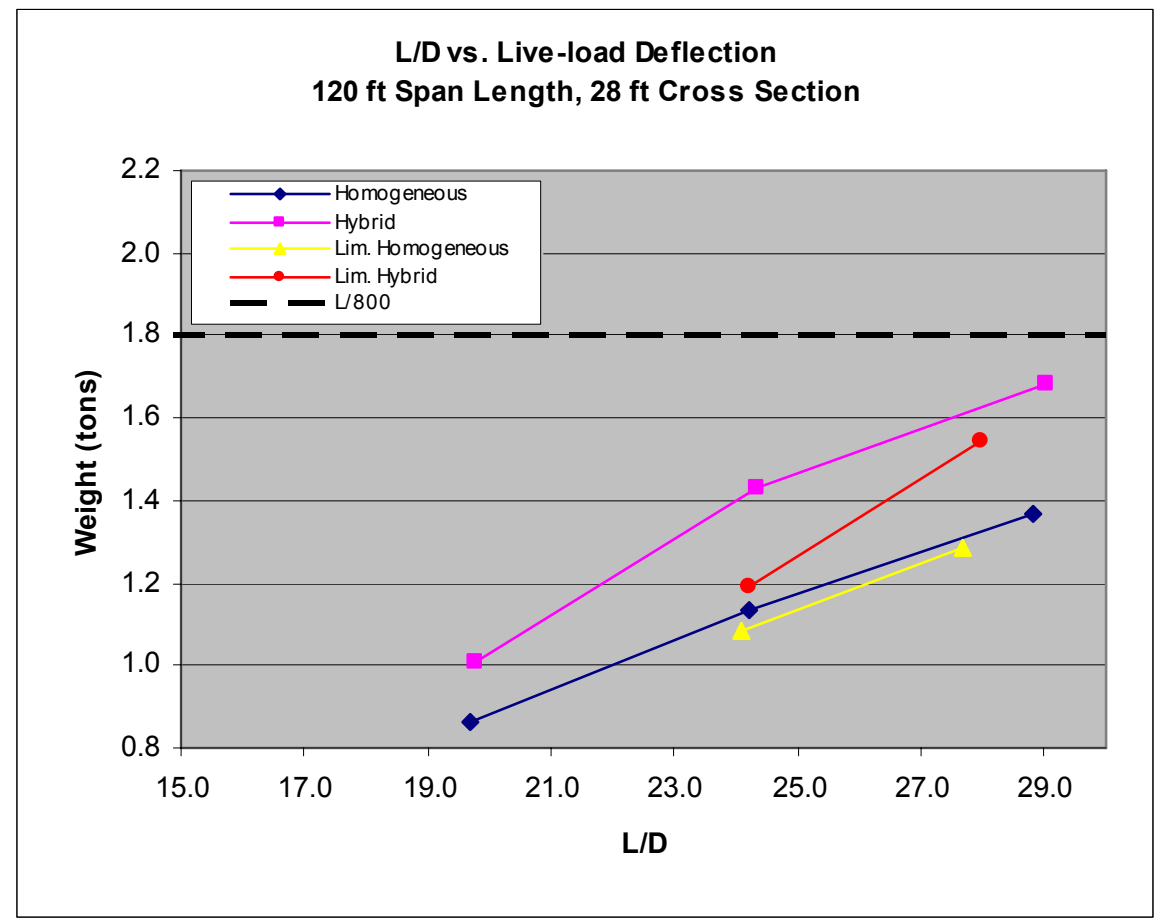

Figure 5.10 Limited Plate Design Deflection for Exterior Girders

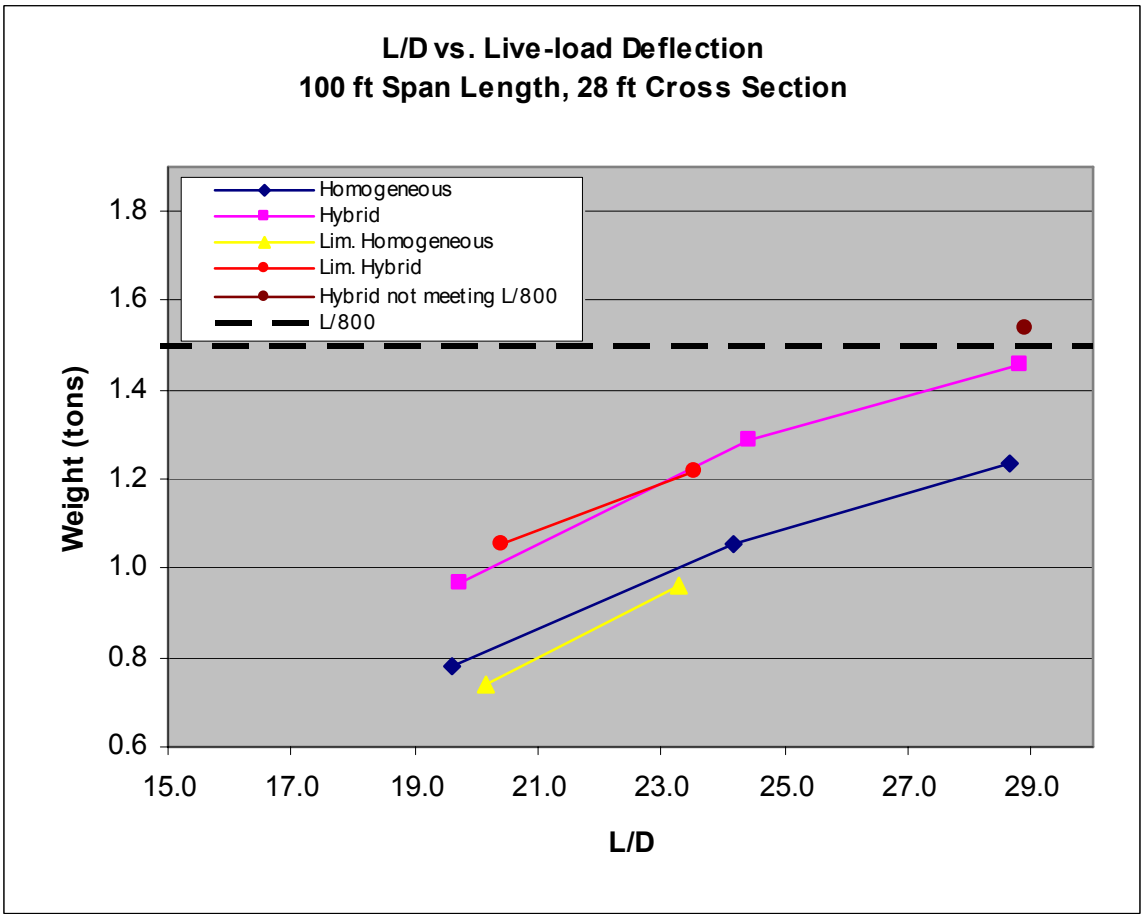

Figure 5.11 Limited Plate Design Deflection for Exterior Girders 


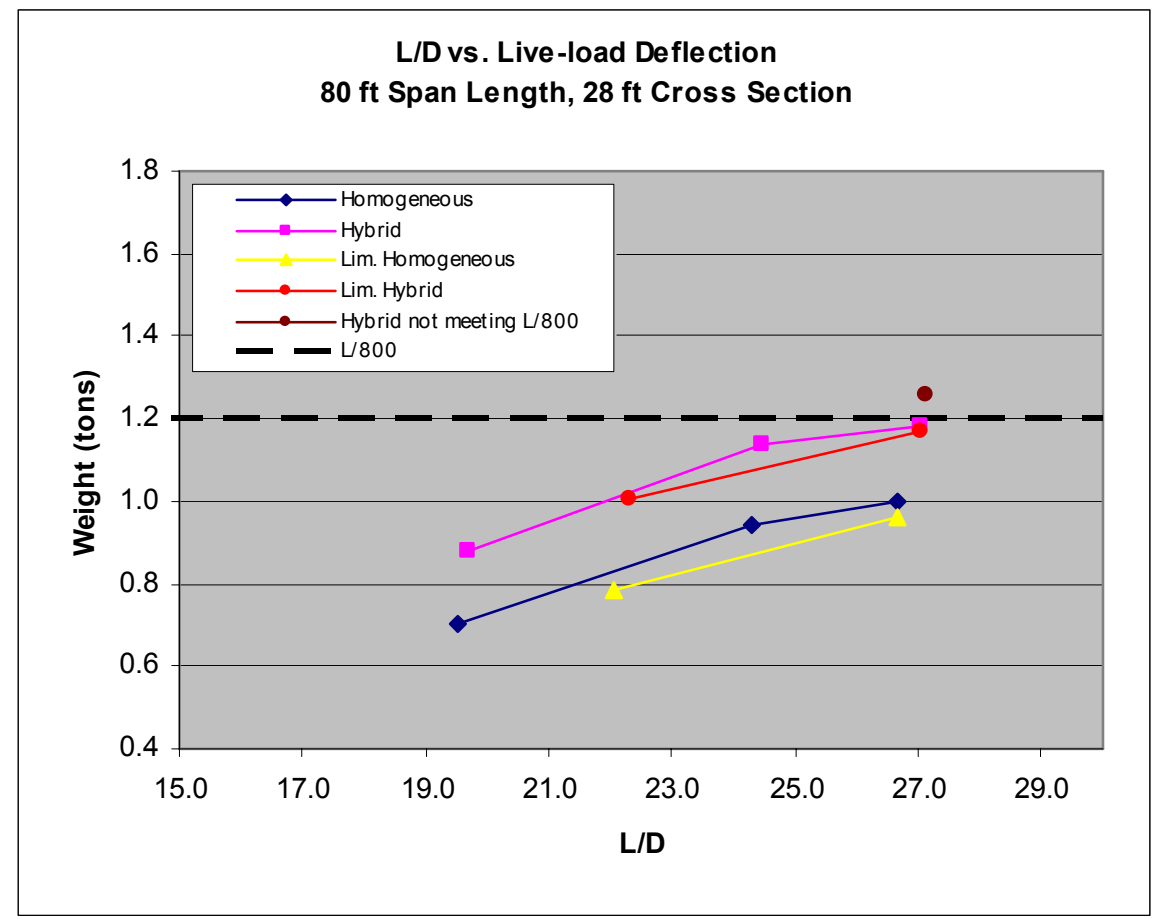

Figure 5.12 Limited Plate Design Deflection for Exterior Girders

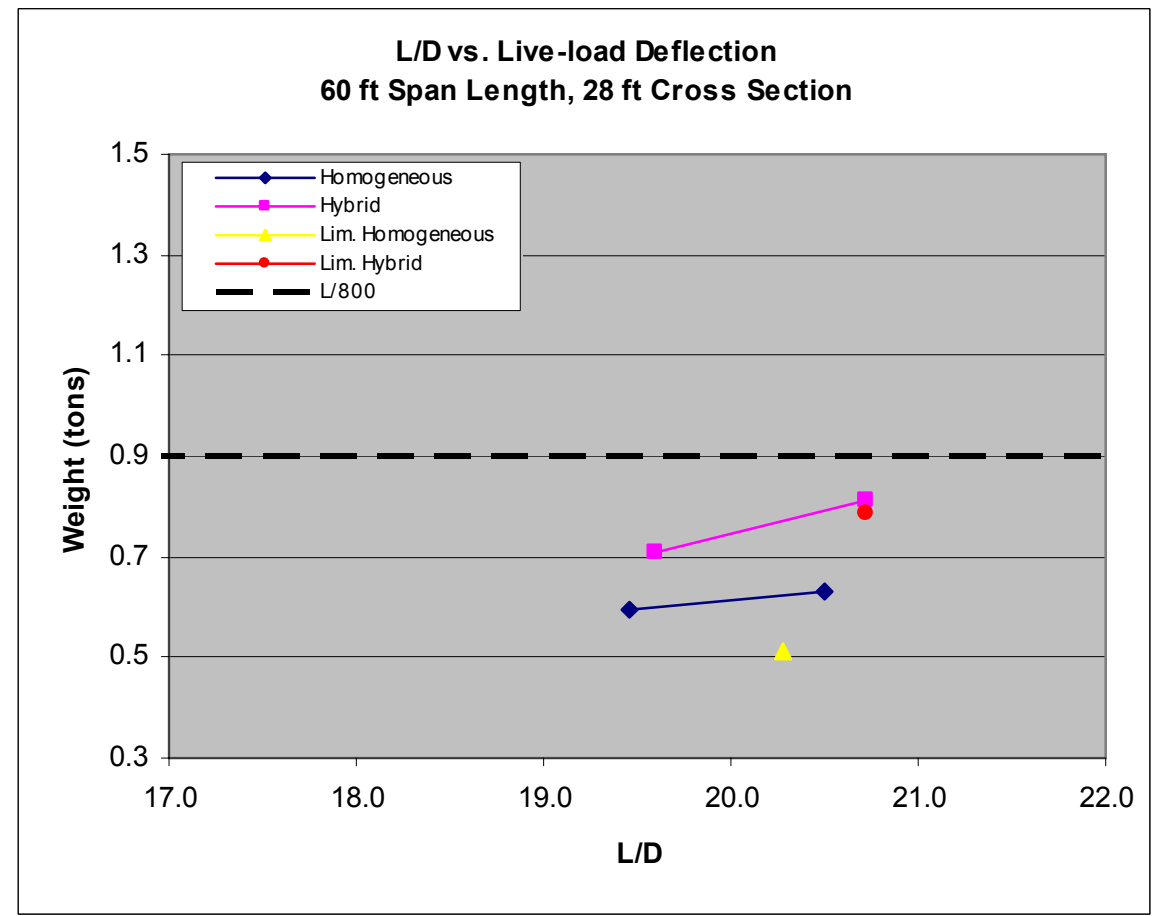

Figure 5.13 Limited Plate Design Deflection for Exterior Girders 


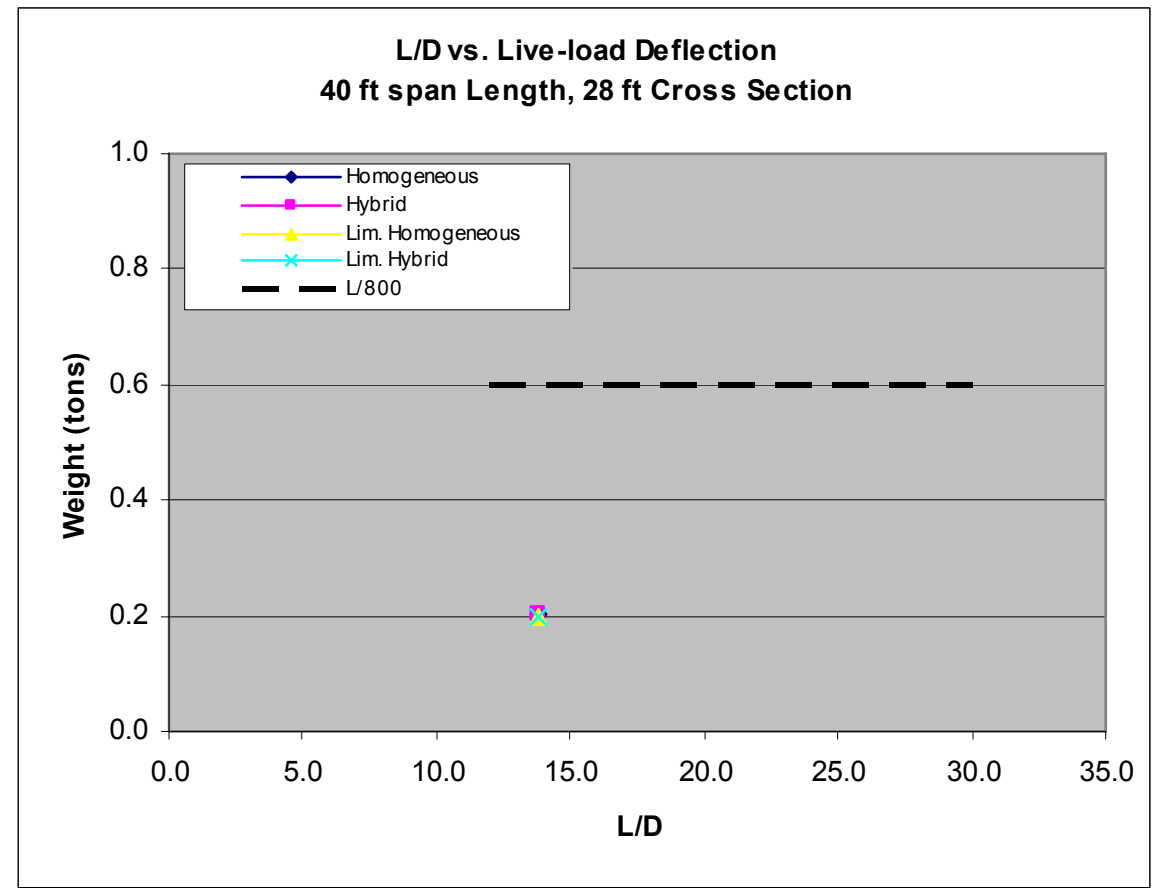

Figure 5.14 Limited Plate Design Deflection for Exterior Girders 


\section{Chapter 6}

\section{Summary and Concluding Remarks}

\subsection{Introduction}

The focus of this study was to develop a standardized bridge girder package for short-span steel I-girder systems. Two design studies were conducted and a summarized description of the observations with regard to live-load deflection, weight and performance is presented in this chapter.

Chapter 2 presented a literature review of the basic steel bridge design guidelines, an overview of standardized bridge packages and methods of currently employed rapid construction techniques. The following section, Chapter 3 detailed the fundamental design procedures based on the $3^{\text {rd }}$ Edition of the AASHTO LRFD Bridge Design Specifications. The topics in this chapter discusses the basic limit states, flexural and shear capacity checks, constructability and fatigue design as well as geometric proportions.

A series of parametric design studies were conducted varying the span length, material configuration, and span-to-depth ratios for two bridge cross section. Designs were completed for homogeneous (50 ksi), hybrid (50/70 ksi) plate girders and rolled beam sections. Sections were designed utilizing un-stiffened and partially stiffened webs. 


\subsection{Scope of Work}

This research includes two studies conducted on short-span bridge design. An optimized design study based on span lengths between 40 feet and 140 feet was completed. Girders were designed for homogeneous 50 ksi configurations, hybrid HPS $70 \mathrm{~W} / 50 \mathrm{ksi}$ plate girders, and $50 \mathrm{ksi}$ rolled beams. Designs were completed for two bridge cross sections: a 28 feet clear roadway width cross section carrying tow design lanes on four girders spaced at 8'-3", and a 34 feet cross section with two design lanes and four girders spaced at 10'-0". The designs were optimized based on weight and were checked against the live-load deflection limit. Observations and conclusions based on girder weight, span-to-depth ratio, girder location, material configuration and live-load deflection was presented.

A study concentrating on the economy of designs based on limited plate size availability was also conducted. The designs were limited to six plate thicknesses and four web depths to evaluate the economy of stock piling more common plate sizes. Span lengths ranged from 40 feet to 140 feet incorporating the above mentioned homogeneous $50 \mathrm{ksi}$ and the hybrid HPS 70W/50 ksi girder configurations. A discussion on the comparison between the optimized designs and the limited plate size designs was completed. 


\subsection{Summary of Results}

This section presents a brief overview of the previously discussed observations from the extensive design studies.

It is concluded from the optimized designs that the economy of the hybrid girder configuration depends on the span length and the span-to-depth ratio. Hybrid designs with lower span to depth ratios are generally more economical than homogeneous sections. Also, the difference in weight between hybrid and homogeneous designs decreases as span length decreases until they both equal because of minimum plate restrictions.

Observing the girder economy based on the span-to-depth ratio it could be noted, that the girders with higher span-to-depth ratios weighed the most. Additionally, sections with larger span-to-depth ratios were more likely to fail the optional live-load deflection limit of L/800.

The optimized short span design study indicates that without the implementation of temporary bracings at mid-span, the influence of the construction limit state for exterior girders can be significant. As a consequence, the use of temporary bracings during construction stages, at mid-span locations to prevent lateral bending of the compression flanges, is recommended. 
Rolled beam sections have found to weigh more than plate girders except for shorter span lengths as a result of the minimum plate size restrictions. It was observed, that the difference between plate girder and rolled beam weight for span lengths of 50 feet to 85 feet are relatively small, which could be offset with steel and fabrication cost. For larger span lengths, because of the shallower rolled beam sections, rolled beam designs were found to be significantly heavier.

The limited plate size study concluded that the weight difference between the optimized and limited designs are not significant. Therefore, it could be more economical to purchase steel in more common plate sizes to offset the difference compared to the optimized designs.

\subsection{Concluding Remarks}

From the results of this research study it could be concluded, that the hybrid designs are more economical for longer span lengths. Hybrid sections were not found to offer weight advantages for shorter spans because of the minimum plate restrictions. It was also concluded, that the rolled beam sections were more economical for the shortest span lengths, however they were shown to be significantly heavier than plate girders for longer span lengths. 
The limited plate size designs were heavier but competitive in weight to the weight optimized sections, and therefore could offer economical advantages when purchasing common plate sizes for a fabricator is an option.

The result of this research is a bridge design package. This short span steel bride envelope is designed according to the $3^{\text {rd }}$ Edition of the AASHTO LRFD Bridge Design Specifications. The goal of such a package is to facilitate the cost efficient replacement or design of new bridge structures. To broaden the spectrum of this design package, further improvements should concentrate on incorporating skewed structures and additional cross sections. 


\section{References}

AASHTO (2004). LRFD Bridge Design Specifications, $3^{\text {rd }}$ Ed., American association of State highway and Transportation officials, Washington, D.C., 2004.

American Iron and Steel Institute. "Criteria for the deflection of steel bridges" by R.N. Wright and W.H. Walker

Clingenpeel, Beth. (2001). "Economical Use of High Performance Steel in SlabonSteel Stringer Bridge Design.” Thesis (M.S.) West Virginia University.

Clingenpeel, Beth F., and Barth, Karl E. (2003) "Design Optimization Study of a Three Span Continuous Bridge Using HPS70W.” AISC Engineering Journal. 39(3): 121-126.

Gopu, Vijaya (March 2004). “Development of Standardized Bridge Systems.” University Transportation Center for Alabama.

Barth Karl E., righman Jennifer E., Wolfe Lora B. ( ) "Assesment of AASHTO LRFD Specifications for Hybrid HPS 100W Steel I girders"

Wilson Alexander D. "Advances in high performance steels for highway bridges", NSBA White Paper

FHWA International Technology Exchange Programs. (2004) Prefabricated Bridge Elements and Systems in Japan and Europe Summary Report

Ralls Mary Lou., Medlock Ronald D., Slagle Sharon. (2002) "Prefabricated Bridge National Implementation Initiative"

Hagen Kevin., (2005) "Development and Construction of Precast Inverted T System for Expediting Minnesota Slab Span Bridge Projects, 2005 Concrete Bridge Conference

American Iron and Steel Institute. (2000). "Short Span Steel Bridges” NACE Annual Meeting, American Iron and Steel Institute.

West Virginia University (2000) "Short Span Steel Bridge Workshop". American Iron and Steel Institute, NACE, Stupp Bros. Bridge \& Iron Company, URS Corporation, WVU

Roeder Charles W., Barth Karl E., Bergman Adam. (2002) “Improved Live Load Deflection Criteria for Steel Bridges, NCHRP (Project 20-7[133]): Contractor's Final Report 
U.S. Department of Transportation Federal Highway Administration (1987) "The Development of Economical Low-Volume Road Bridges", DOT FHWA/DF/87/002 Final Report

Freeman, Lora. (2005). "Development of an Optimized Short-span Steel Bridge Package." Thesis (M.S.) West Virginia University.

NSBA (2005) "Advances in high performance steels for highway bridges"

By Alexander D. Wilson, Manager, Customer Technical Service, Mittal Steel USA http://www.steelbridges.org/pdfs/Environment.pdf 
Appendix

Tables of Designs 


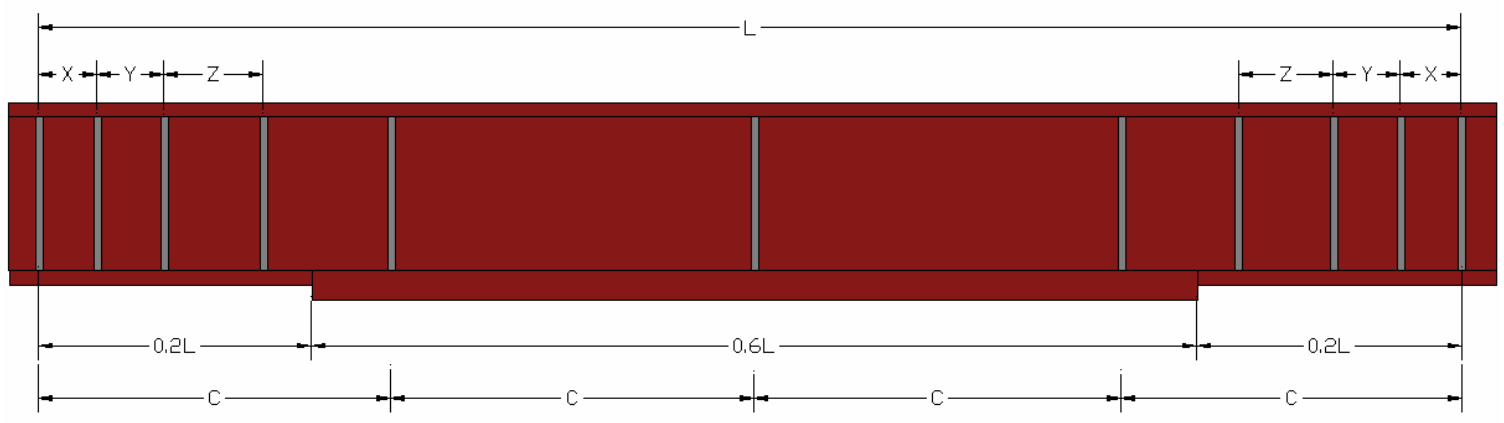

Figure A.1 Typical Girder Elevation

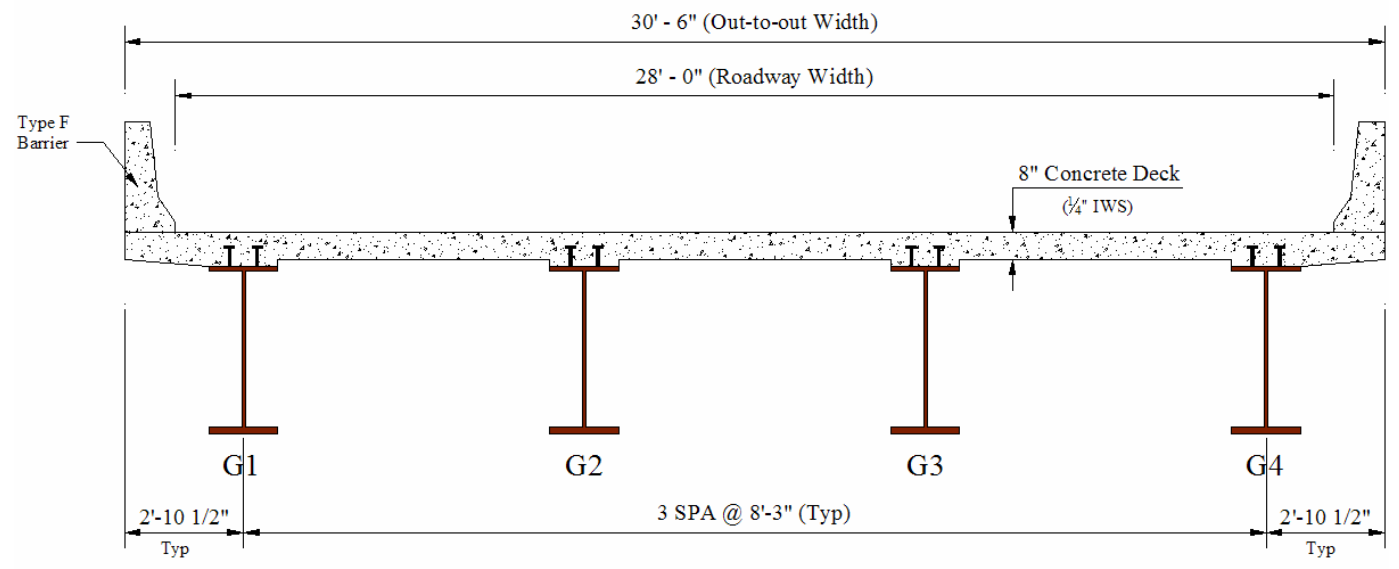

Figure A.2 Bridge Cross-section with 28 -ft Clear Roadway Width

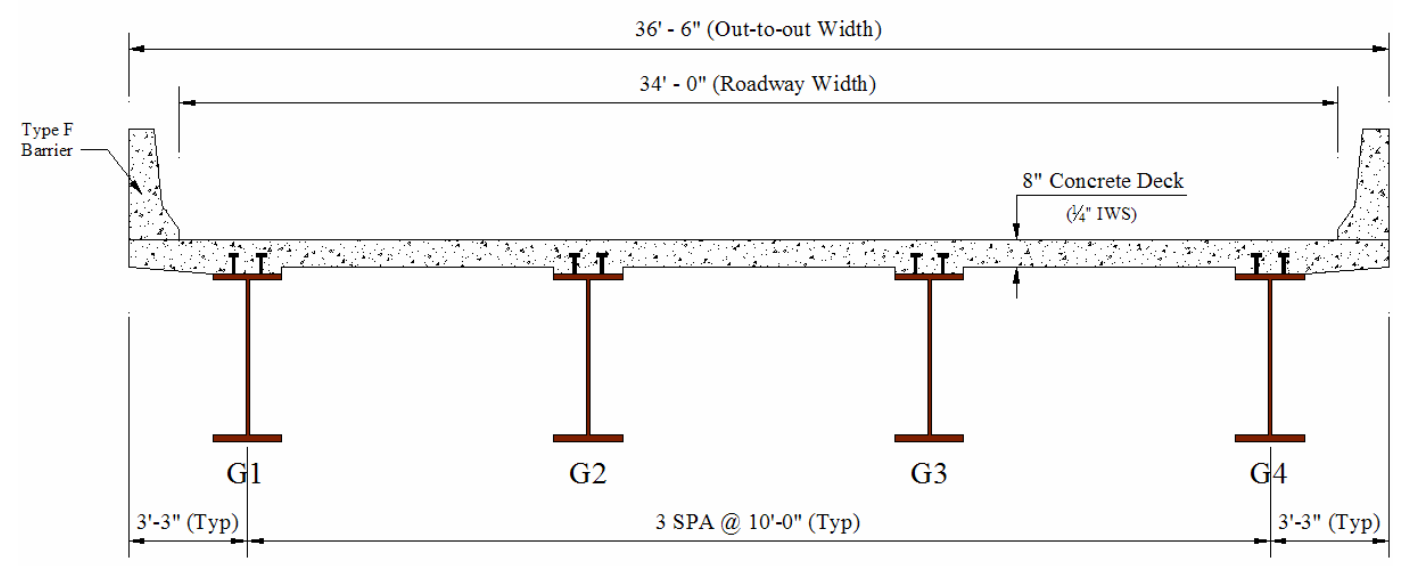

Figure A.3 Bridge Cross-section with $34 \mathrm{ft}$. Clear Roadway Width 


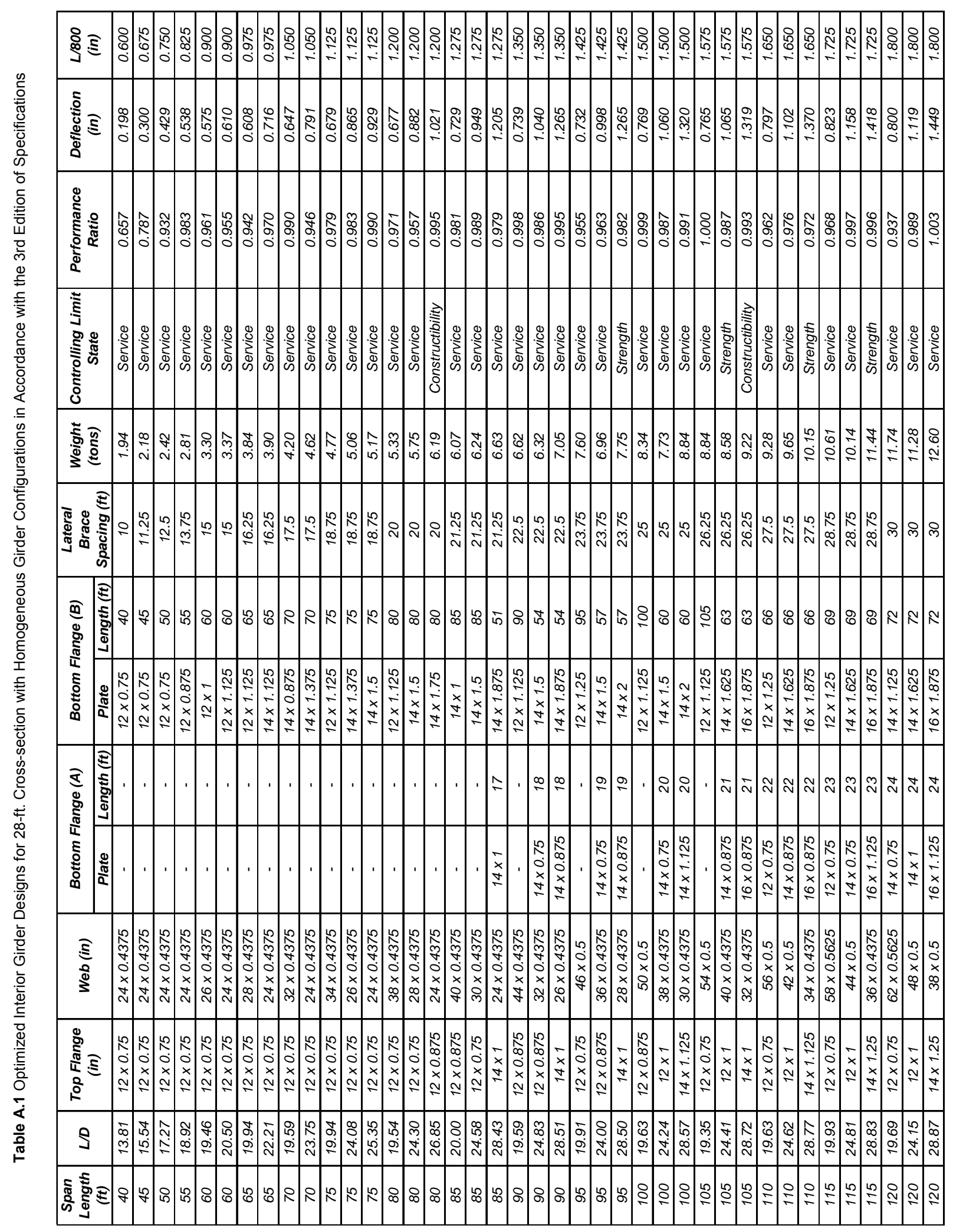




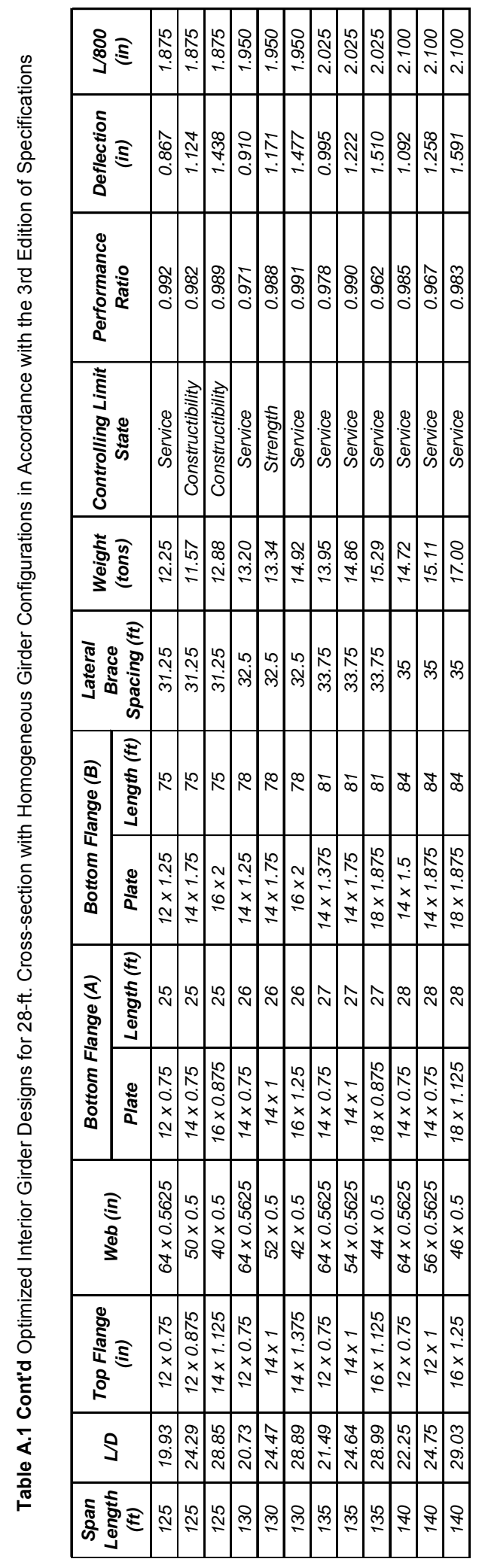




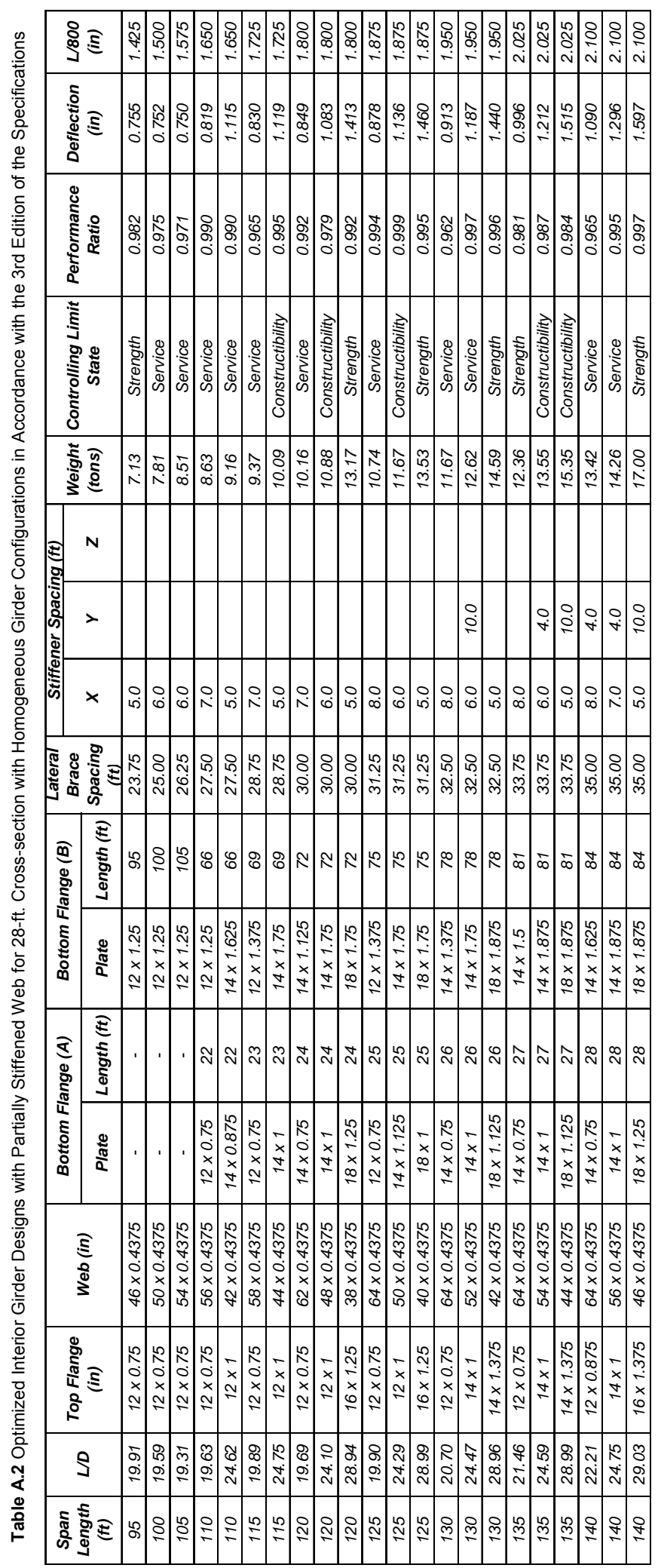




\begin{tabular}{|c|c|c|c|c|c|c|c|c|c|c|c|c|c|c|c|c|c|c|c|c|c|c|c|c|c|c|c|c|c|c|}
\hline$\stackrel{\infty}{\Xi} \Xi$ & $\mid$\begin{tabular}{l|l}
8 & 5 \\
0 & 0 \\
0 & 0
\end{tabular} & 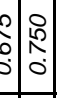 & $\mid \begin{array}{l}\mathscr{D} \\
\infty \\
0 \\
0\end{array}$ & & $\begin{array}{l}8 \\
8 \\
\vdots \\
0 \\
0\end{array}$ & 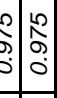 & $\mid$ & 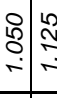 & 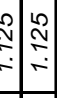 & 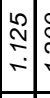 & & & 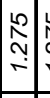 & 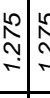 & 足 & & ֵొ & ป̂] & $\stackrel{\substack{N \\
\sim}}{-i}$ & 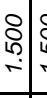 & & & 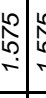 & 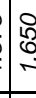 & & & & & $\begin{array}{c}8 \\
\infty \\
-1 \\
\end{array}$ & $\begin{array}{ccc}8 & 8 \\
\infty & \infty \\
-i & - \\
\end{array}$ \\
\hline 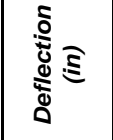 & 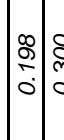 & & & & & & & & & & & & $\left|\begin{array}{l}\infty \\
0 \\
0 \\
0\end{array}\right|$ & & & & & & & & & & & & $\stackrel{\mathscr{S}}{-}$ & & & & $\begin{array}{c}0 \\
0 \\
0 \\
0 \\
0\end{array}$ & 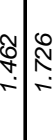 \\
\hline 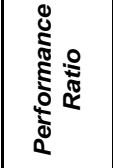 & 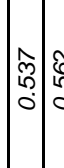 & & & 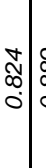 & & & & & & 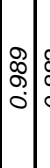 & & & $\mid \begin{array}{l}\infty \\
- \\
0 \\
0\end{array}$ & & & & & & & & $\begin{array}{c}\infty \\
0 \\
0 \\
0\end{array}$ & 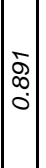 & & & & & & & 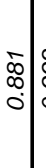 & 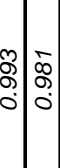 \\
\hline 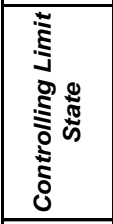 & 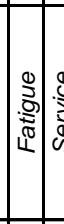 & & & & & & & & 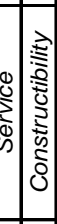 & 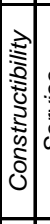 & & 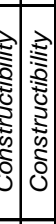 & & & 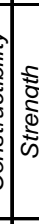 & & 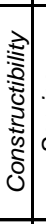 & 峁 & $\tilde{m}$ & $\stackrel{\oplus}{\omega}$ & 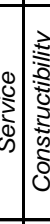 & 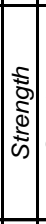 & & 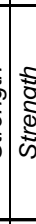 & $\delta$ & $\stackrel{0}{\omega}$ & & & ט. & 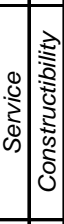 \\
\hline 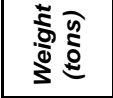 & 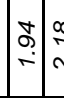 & 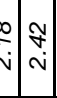 & $\mid \begin{array}{l}\hat{0} \\
\stackrel{\sim}{*}\end{array}$ & $\stackrel{8}{.}$ & 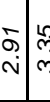 & 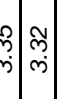 & $\mid \begin{array}{l}\overrightarrow{0} \\
0 \\
\dot{m}\end{array}$ & 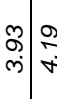 & 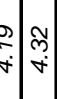 & $\left(\begin{array}{l}N \\
\dot{\sigma} \\
\dot{\sigma}\end{array}\right.$ & 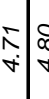 & 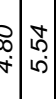 & 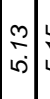 & & 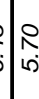 & $\begin{array}{c}1 \\
\infty \\
\text { co }\end{array}$ & & 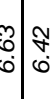 & : & & \begin{tabular}{c}
$\mid$ \\
\hdashline \\
0
\end{tabular} & & 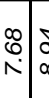 & & $\begin{array}{l}2 \\
\infty \\
\infty\end{array}$ & & 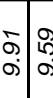 & 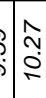 & 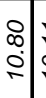 & 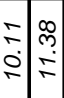 \\
\hline 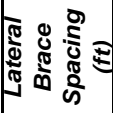 & & & 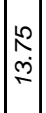 & $\rightarrow$ & 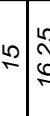 & & $\begin{array}{l}0 \\
\\
-1\end{array}$ & 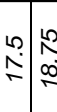 & 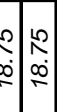 & $\left|\begin{array}{c}\kappa \\
0 \\
\infty \\
-1\end{array}\right| \delta$ & & $\stackrel{\sim}{*}$ & 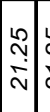 & 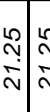 & & $\stackrel{L}{\sim}$ & 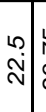 & 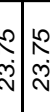 & & & $\sim \sim$ & $\left|\begin{array}{l}\stackrel{\wp}{\sim} \\
\stackrel{\leftrightarrow}{\sim}\end{array}\right|$ & 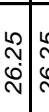 & & & & & & ळ) & ळ) \\
\hline 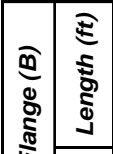 & $8: 5$ & $f(\circ)$ & 吊 & : & & $\begin{array}{llll}8 & 0 \\
0\end{array}$ & $\curvearrowright$ & 2 & 尺 & 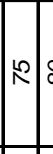 & $\infty \overbrace{\infty}$ & \begin{tabular}{l|l}
$\infty$ \\
\end{tabular} & $\infty$ & $\infty$ & 8 & ৪ & & क) & & 위 & : & & 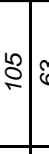 & & & & & 8 & స్ & సิ \\
\hline 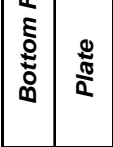 & 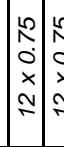 & & 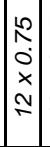 & 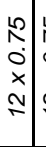 & 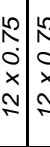 & 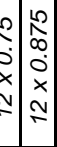 & $\begin{array}{l}1 \\
\stackrel{2}{1} \\
\dot{0} \\
x \\
\sim \\
\sim\end{array}$ & & 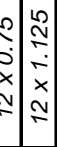 & 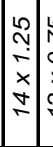 & & 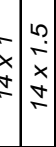 & 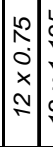 & 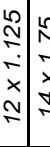 & 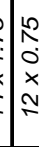 & 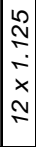 & 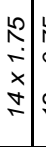 & 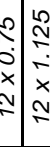 & $\mid \begin{array}{l}n \\
\\
-1 \\
x \\
-1 \\
-1 \\
\end{array}$ & 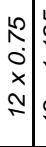 & 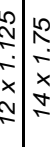 & & 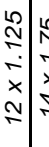 & 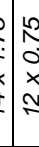 & 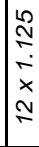 & & & & 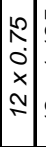 & 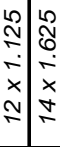 \\
\hline 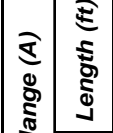 & & & & & & & & & & . & & 1 & 1 & A & 4 & & $\stackrel{\infty}{\sim}$ & & ㄱ. & & $\stackrel{2}{2}$ & & i & & & $\approx$ & & $\stackrel{m}{N}$ & 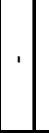 & $1 \pm$ \\
\hline 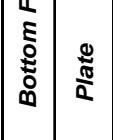 & & & & & & & & & & & & $\left|\begin{array}{l}-1 \\
x \\
-7\end{array}\right|$ & & 7 & $\begin{array}{l}4 \\
x \\
x \\
\end{array}$ & & 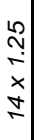 & & & & & & & & & & & & & \\
\hline 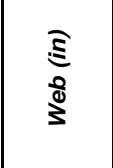 & 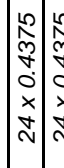 & 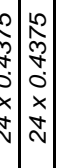 & 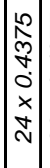 & 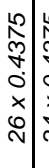 & 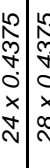 & 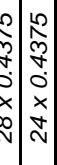 & 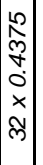 & 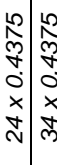 & 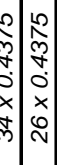 & 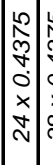 & 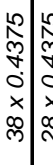 & 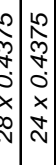 & 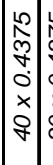 & 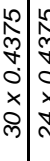 & 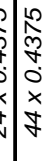 & 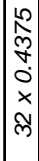 & 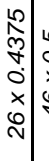 & 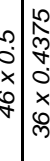 & $\begin{array}{l}\hat{1} \\
\hat{y} \\
0 \\
0 \\
x \\
\infty \\
\infty\end{array}$ & $\mid \begin{array}{l}0 \\
0 \\
0 \\
x \\
0 \\
i \\
1\end{array}$ & 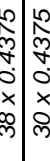 & $\begin{array}{l}10 \\
0 \\
\times \\
\times \\
5 \\
5\end{array}$ & 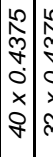 & 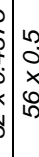 & 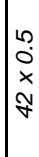 & 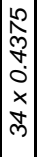 & 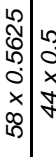 & 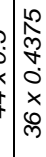 & 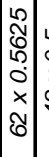 & 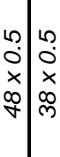 \\
\hline 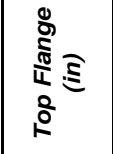 & 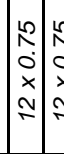 & 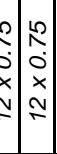 & 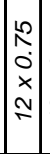 & 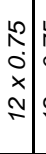 & 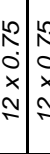 & 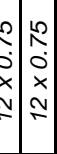 & 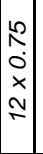 & 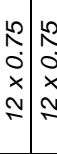 & 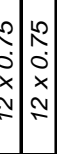 & 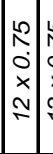 & 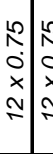 & 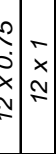 & 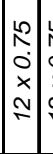 & 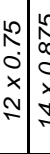 & 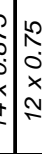 & $\mid \begin{array}{l}1 \\
0 \\
0 \\
0 \\
x \\
x \\
N\end{array}$ & 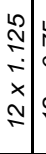 & 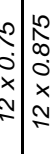 & 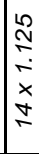 & 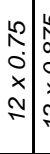 & 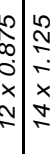 & 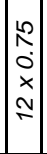 & 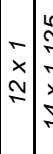 & $\begin{array}{l}n \\
0 \\
0 \\
x \\
x \\
x\end{array}$ & \begin{tabular}{l}
$\tilde{x}$ \\
$\times$ \\
\cline { 1 - 1 }
\end{tabular} & $\mid$ & 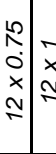 & 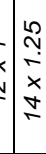 & $\mid \begin{array}{l}0 \\
1 \\
0 \\
x \\
x \\
-7 \\
\mid\end{array}$ & 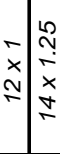 \\
\hline 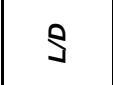 & 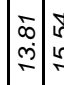 & 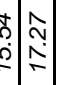 & $\left|\begin{array}{l}2 \\
0 \\
0 \\
-1\end{array}\right|$ & 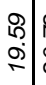 & 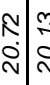 & 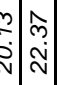 & $\mid$ & $\begin{array}{l}3 \\
\text { ฟุ }\end{array}$ & 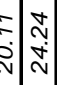 & $\left|\begin{array}{l}n \\
\hat{b} \\
\hat{d} \\
\end{array}\right|$ & 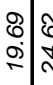 & 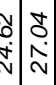 & $\left|\begin{array}{l}0 \\
-1 \\
2 \\
\end{array}\right|$ & 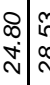 & ? & & $\begin{array}{l}\vec{b} \\
\substack{0 \\
\sim}\end{array}$ & 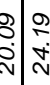 & ( & 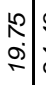 & 舟 & $\left|\begin{array}{l}0 \\
0 \\
0 \\
-1\end{array}\right|$ & 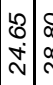 & 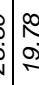 & & & 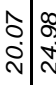 & 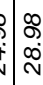 & 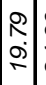 & 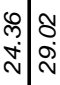 \\
\hline 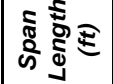 & 8 & $f \circ$ & 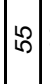 & : & 8 & $\begin{array}{llll}8 & 0 \\
0\end{array}$ & 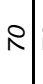 & 尺 & & 绝 & $\infty$ & \begin{tabular}{l|l}
$\infty$ & $\infty$
\end{tabular} & $\infty$ & $\stackrel{\infty}{\infty}$ & & & 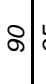 & ᄋ) & & & 8 & $\stackrel{8}{2}$ & $\neg$ & & & & $\stackrel{2}{7} \stackrel{n}{7}$ & 4 & $\stackrel{\sim}{\approx}$ & \\
\hline
\end{tabular}




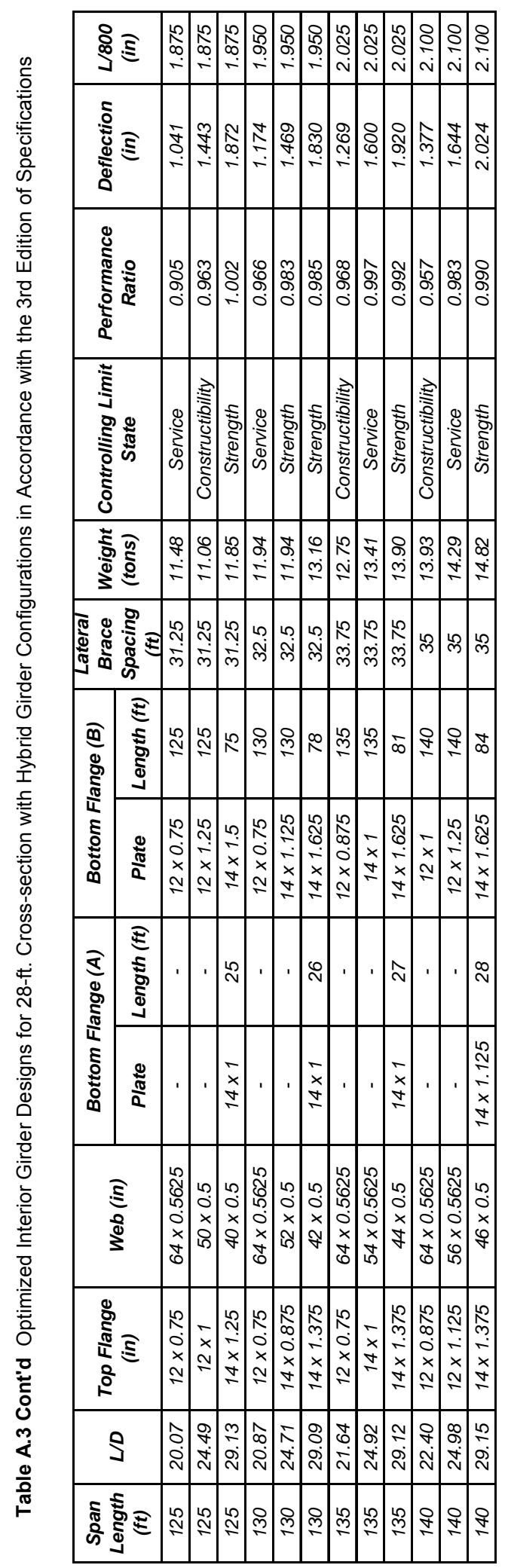




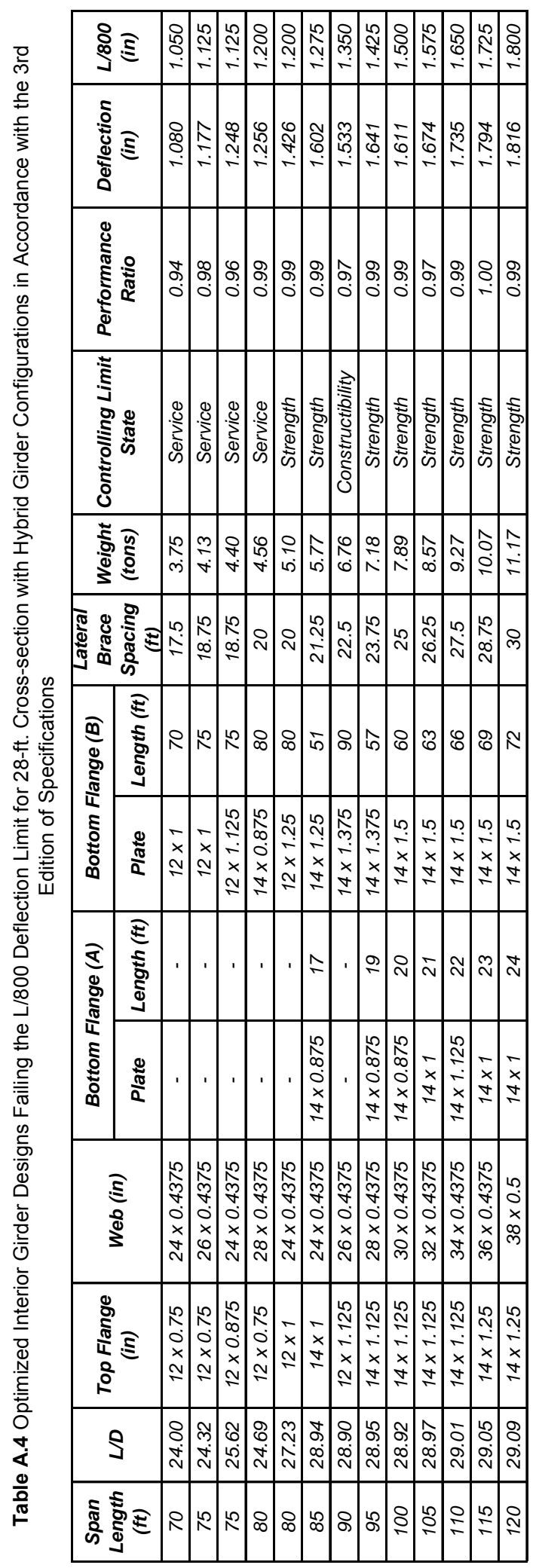




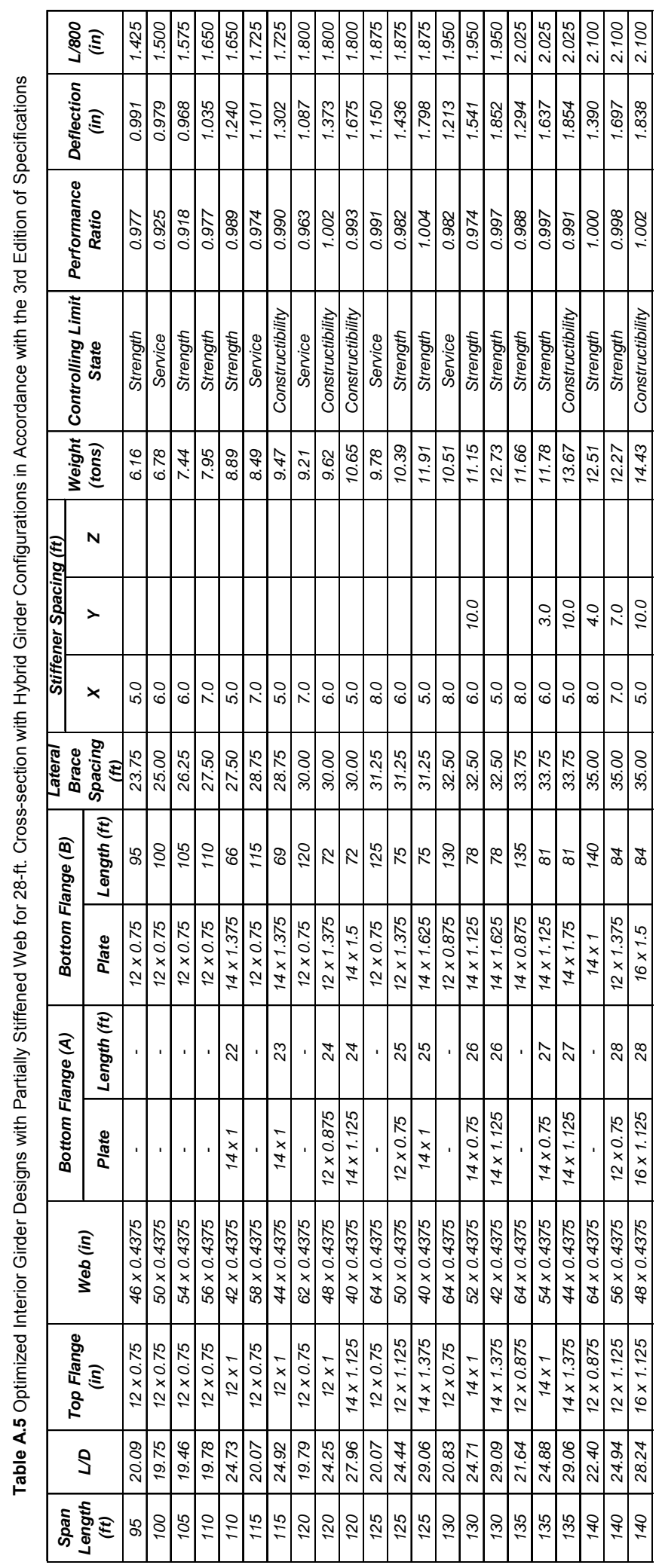




\begin{tabular}{|c|c|c|c|c|c|c|c|c|c|c|c|c|c|c|c|c|c|c|c|c|c|c|c|c|c|c|c|c|c|c|}
\hline ః & $\begin{array}{l}: \\
\vdots \\
0 \\
0\end{array}$ & $\mid \begin{array}{l}0 \\
6 \\
0 \\
0\end{array}$ & $\mid \begin{array}{l}0 \\
\\
0 \\
0\end{array}$ & $\begin{array}{c}\stackrel{2}{0} \\
\infty \\
0 \\
0\end{array}$ & & & $\begin{array}{l}n \\
\vdots \\
0 \\
0\end{array}$ & 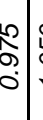 & & ר. & & 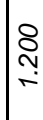 & 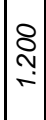 & 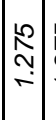 & & & & $\left|\begin{array}{c}\Omega \\
\mathcal{Y} \\
\sim \\
-i\end{array}\right|$ & 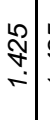 & & 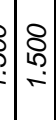 & $\mid \begin{array}{l}8 \\
1 \\
-i \\
-i\end{array}$ & $\mid \begin{array}{c}1 \\
0 \\
h \\
-1 \\
-1\end{array}$ & $\begin{array}{c}0 \\
0 \\
i \\
-1\end{array}$ & $\begin{array}{l}8 \\
6 \\
6\end{array}$ & $\left|\begin{array}{c}\stackrel{\sim}{N} \\
- \\
-\end{array}\right|$ & $\begin{array}{c}8 \\
\infty \\
-i\end{array}$ & & & \\
\hline 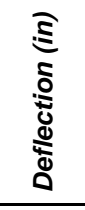 & 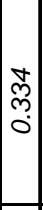 & & & & & & $\begin{array}{c}\hat{N} \\
\omega \\
0 \\
0\end{array}$ & 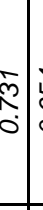 & & & & & $\mid \begin{array}{l}0 \\
\infty \\
0 \\
0\end{array}$ & $\left|\begin{array}{l}2 \\
\hat{2} \\
0 \\
0\end{array}\right|$ & \begin{tabular}{c|c}
8 & $\vdots$ \\
$\infty$ & $\vdots$ \\
$\vdots$ &
\end{tabular} & & & $\mid \begin{array}{l}0 \\
\tilde{0} \\
0 \\
0\end{array}$ & 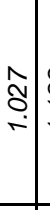 & 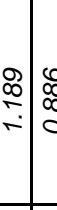 & $\begin{array}{l}: \\
\dot{b} \\
\dot{b}\end{array}$ & $\left|\begin{array}{l}\infty \\
-7 \\
-i\end{array}\right|$ & 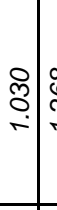 & & & 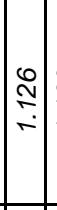 & & & & \\
\hline$\frac{\alpha}{R}$ & $\begin{array}{l}\circ \\
\stackrel{2}{ } \\
\circ\end{array}$ & 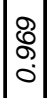 & $\mid \begin{array}{c}7 \\
5 \\
0\end{array}$ & 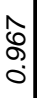 & $\begin{array}{l}\hat{0} \\
\stackrel{0}{0}\end{array}$ & ठี & 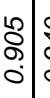 & 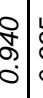 & $\begin{array}{l}6 \\
. \\
6 \\
6\end{array}$ & & 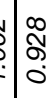 & 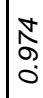 & 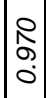 & $\mid$ & 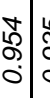 & $\begin{array}{l}0 \\
\widetilde{\sigma} \\
0 \\
\end{array}$ & 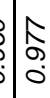 & $\mid \begin{array}{l}0 \\
0 \\
0 \\
0 \\
0\end{array}$ & $\begin{array}{l}\infty \\
: \\
0 \\
0\end{array}$ & & $\begin{array}{ll}4 \\
\\
\circ\end{array}$ & $\mid \begin{array}{l}-1 \\
\hat{2} \\
0\end{array}$ & \begin{tabular}{|l|}
$m$ \\
$\sigma$ \\
$\delta$ \\
$\delta$
\end{tabular} & 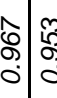 & $\mid \begin{array}{l}2 \\
2 \\
2\end{array}$ & $\mid \begin{array}{l}\infty \\
\tilde{O} \\
0\end{array}$ & $\begin{array}{l}\hat{\delta} \\
\delta \\
\delta\end{array}$ & & & \\
\hline 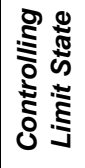 & 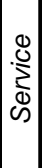 & 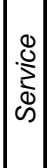 & & & & & & & & & & & 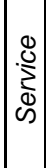 & 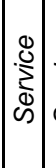 & & & & & & & 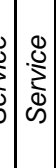 & & & & & 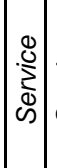 & & & & \\
\hline 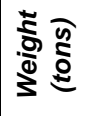 & $\begin{array}{l}\stackrel{\wp}{+} \\
-i\end{array}$ & $\mid \begin{array}{l}\infty \\
\stackrel{\sim}{\sim} \\
\mid\end{array}$ & 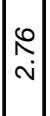 & 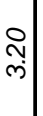 & $\begin{array}{c}m \\
\infty \\
\\
0\end{array}$ & $\begin{array}{c}\mathscr{m} \\
\dot{\sim} \\
\mid\end{array}$ & $\begin{array}{l}\hat{N} \\
+\end{array}$ & 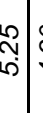 & $\begin{array}{l}8 \\
+ \\
\end{array}$ & $\begin{array}{c}0 \\
\vdots \\
\vdots \\
b\end{array}$ & 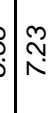 & $\mid \begin{array}{l}0 \\
0 \\
0\end{array}$ & 总 & $\mid \begin{array}{l}0 \\
\wedge \\
\wedge\end{array}$ & $\begin{array}{c}\infty \\
\infty \\
\infty\end{array}$ & \begin{tabular}{c|c}
$\vec{m}$ \\
कें
\end{tabular} & 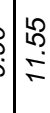 & $\left|\begin{array}{l}8 \\
0 \\
0 \\
-1\end{array}\right|$ & $\begin{array}{l}-1 \\
0 \\
0 \\
-1\end{array}$ & & 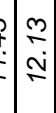 & $\begin{array}{l}\stackrel{8}{ } \\
\dot{m} \\
-1\end{array}$ & & & 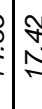 & $\left|\begin{array}{l}0 \\
0 \\
0 \\
-1\end{array}\right|$ & 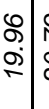 & & & \\
\hline 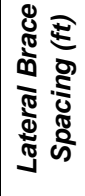 & 이 & 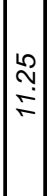 & 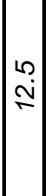 & $\begin{array}{l}\stackrel{2}{2} \\
\stackrel{3}{7} \\
-1\end{array}$ & $\stackrel{\circ}{\rightarrow}$ & $\stackrel{2}{\sim}$ & 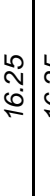 & 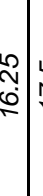 & ר.? & 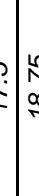 & & ㅇ & กิ & 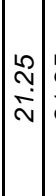 & 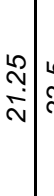 & \begin{tabular}{l|l}
\multirow{N}{*}{} \\
\multirow{2}{*}{}
\end{tabular} & \begin{tabular}{l|l}
$\mathrm{j}$ \\
$\mathrm{N}$
\end{tabular} & 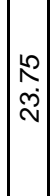 & $\begin{array}{l}\stackrel{L}{ } \\
\\
\end{array}$ & & $\stackrel{\sim}{\sim}$ & $\stackrel{\sim}{\sim}$ & & & & $\left|\begin{array}{l}\stackrel{2}{\Lambda} \\
\infty \\
\sim \\
\sim\end{array}\right|$ & ஓ্ & & & 隹 \\
\hline 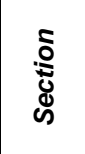 & $\mid \begin{array}{l}0 \\
n \\
x \\
-1 \\
3 \\
3\end{array}$ & 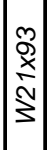 & $\left|\begin{array}{l}z \\
z \\
3 \\
3 \\
3\end{array}\right|$ & 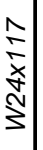 & 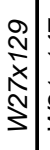 & 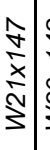 & 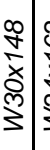 & 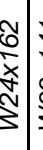 & \begin{tabular}{l}
7 \\
\hdashline \\
\hdashline \\
3 \\
3 \\
3
\end{tabular} & 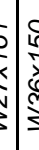 & 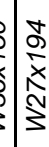 & 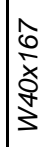 & 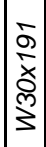 & $\mid \begin{array}{c}m \\
\infty \\
0 \\
\bar{x} \\
\vdots \\
3 \\
3\end{array}$ & 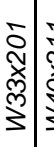 & 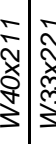 & 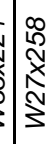 & 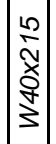 & 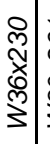 & 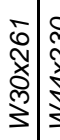 & 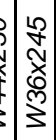 & 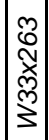 & 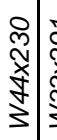 & 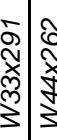 & 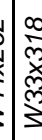 & 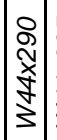 & 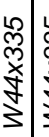 & 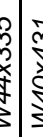 & 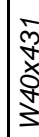 & 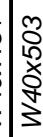 \\
\hline 9 & 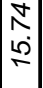 & $\mid \begin{array}{l}0 \\
\\
-1\end{array}$ & 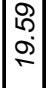 & $\begin{array}{l}\stackrel{2}{2} \\
\stackrel{2}{\rightarrow}\end{array}$ & 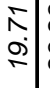 & 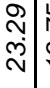 & 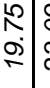 & 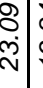 & '. & ְे & 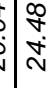 & $\begin{array}{l}\infty \\
\stackrel{-}{1} \\
\stackrel{1}{1}\end{array}$ & $\mid \begin{array}{r}\hat{D} \\
\stackrel{\sim}{\sim}\end{array}$ & $\left|\begin{array}{l}0 \\
\stackrel{0}{2} \\
\vec{N}\end{array}\right|$ & $\begin{array}{l}\stackrel{0}{2} \\
\stackrel{丶}{\sim}\end{array}$ & 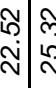 & 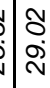 & 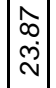 & 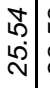 & 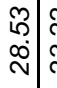 & 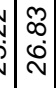 & $\mid \begin{array}{l}m \\
\stackrel{g}{1} \\
\hat{N}\end{array}$ & $\begin{array}{c}\infty \\
m \\
\dot{\sim} \\
\sim \\
\sim\end{array}$ & 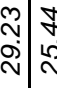 & in & 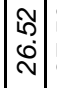 & 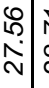 & $\begin{array}{l}y \\
\dot{t} \\
\dot{0}\end{array}$ & m) & $\begin{array}{l}\infty \\
\dot{j} \\
m\end{array}$ \\
\hline ฐू & & & 6 & 织 & 8 & 8 & 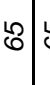 & 8 & R & & 212 & $\infty$ & 0 & $\left|\begin{array}{l}\infty \\
\infty\end{array}\right|$ & ᄂ & ৪) ন & 18 & $\mathscr{\Omega}$ & (ما & ஜ) & : & ৪ & $\mid \begin{array}{l}1 \\
0 \\
0\end{array}$ & 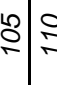 & 7 & $\begin{array}{l}2 \\
\approx \\
7\end{array}$ & ิㅗ & & 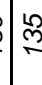 & \\
\hline
\end{tabular}




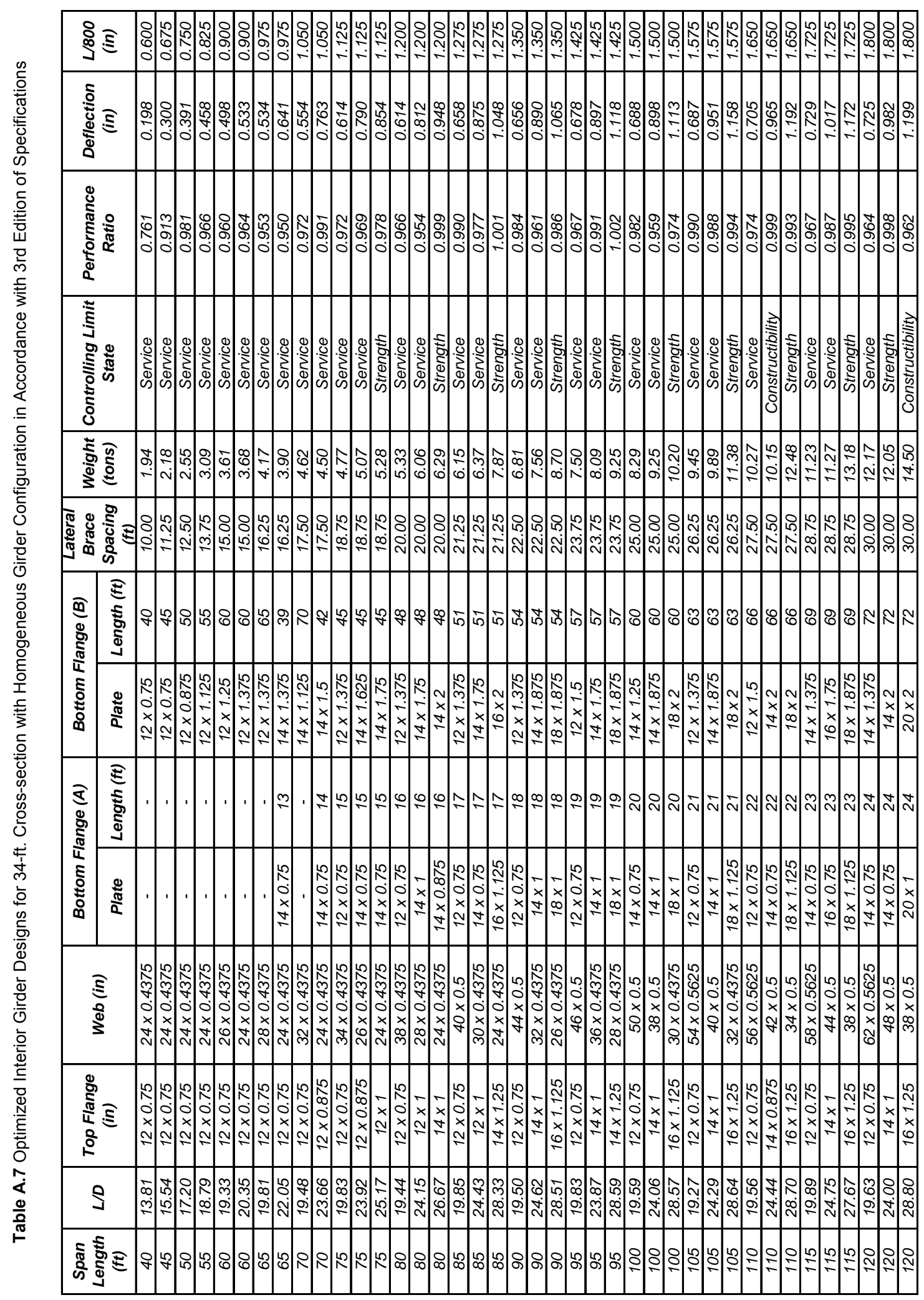




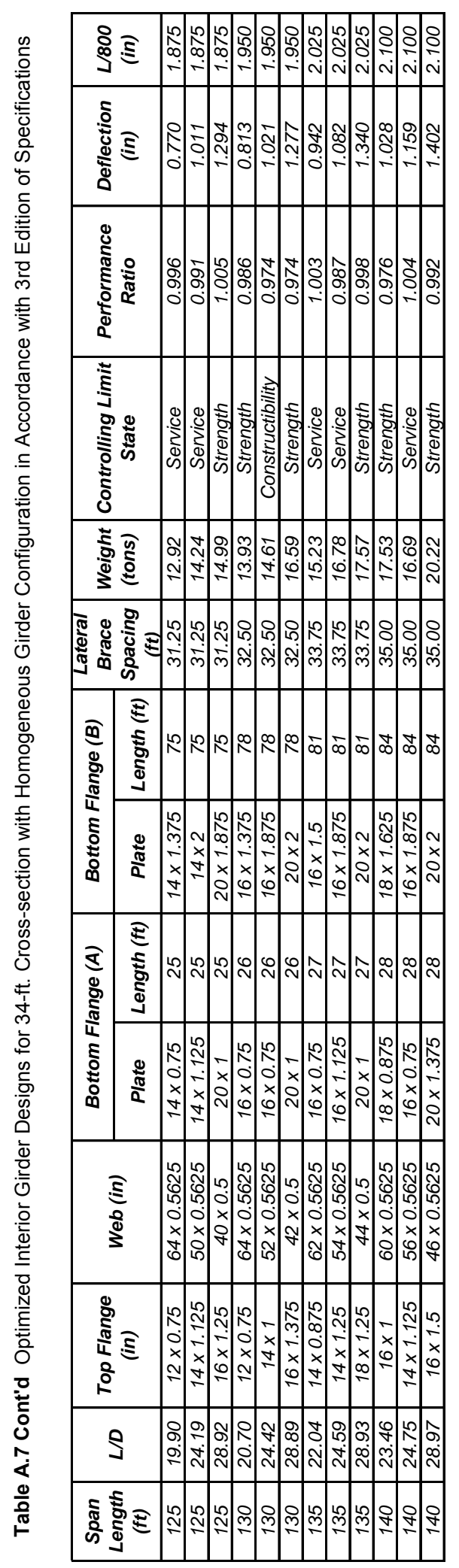




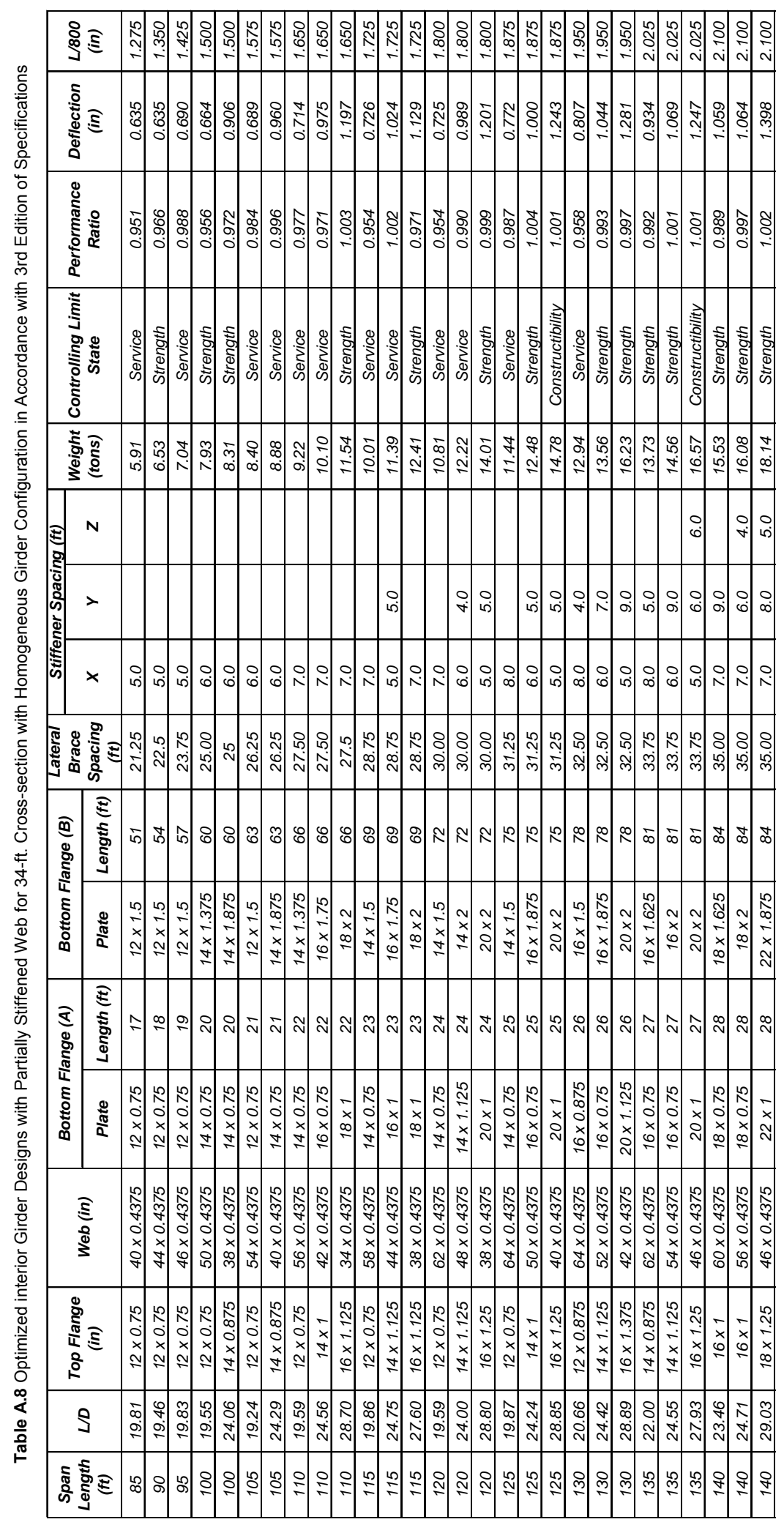




\begin{tabular}{|c|c|c|c|c|c|c|c|c|c|c|c|c|c|c|c|c|c|c|c|c|c|c|c|c|c|c|c|c|c|}
\hline 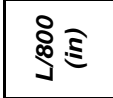 & \begin{tabular}{|ll}
8 & 0 \\
0 \\
0 \\
0 \\
0
\end{tabular} & $\begin{array}{l}0 \\
h \\
0 \\
0\end{array}$ & & $\begin{array}{ll}8 \\
8 \\
\circ\end{array}$ & $\mid \begin{array}{l}1 \\
2 \\
0 \\
0\end{array}$ & & 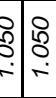 & 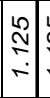 & & 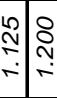 & & & 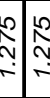 & 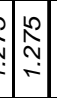 & & : & $\mid$ & & & - & & 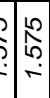 & $\mid \begin{array}{ccc}1 & 0 \\
6 & 0 \\
0 & 0 \\
-1 & 7\end{array}$ & 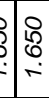 & 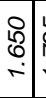 & & & & \\
\hline 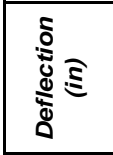 & 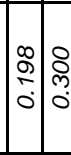 & 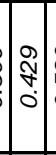 & & & & & & & & & & & & & & & & & & & & & 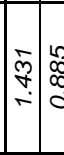 & $\begin{array}{lll}0 \\
0 \\
\vdots \\
\vdots\end{array}$ & & & & & \\
\hline 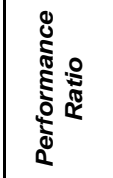 & $\mid \begin{array}{lll}\infty & 1 \\
0 \\
0 \\
0 & 0 \\
0\end{array}$ & & & & & & & & & & & & & 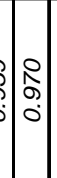 & & & $\left|\begin{array}{l}\qquad \\
0 \\
0 \\
0 \\
0\end{array}\right|$ & & & $\mid$ & & & \begin{tabular}{l|l|l|l}
0 & $\infty$ \\
0 & 0 \\
0 & 0 \\
0 & 0
\end{tabular} & 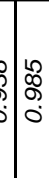 & - & & & & \\
\hline 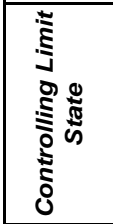 & 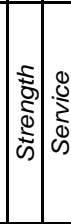 & & & 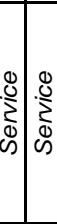 & & & 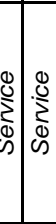 & 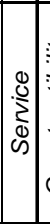 & & 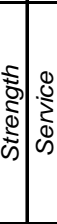 & & & & 范 & & 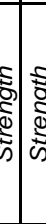 & 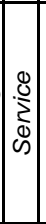 & & 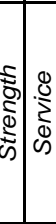 & $\begin{array}{l}0 \\
\vdots \\
0 \\
0 \\
0 \\
0 \\
0\end{array}$ & & $\vec{\omega}$ & 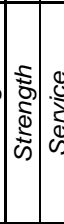 & 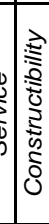 & $\frac{D}{\omega}$ & 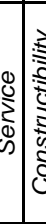 & $\bar{m}$ & & \\
\hline 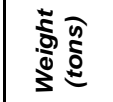 & 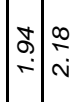 & 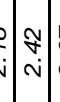 & & 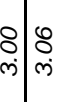 & ch & & 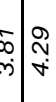 & 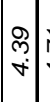 & \begin{tabular}{l|l}
$\hat{y}$ & $a$ \\
$\dot{\gamma}$ & 0
\end{tabular} & \begin{tabular}{l|l}
$\infty$ \\
$\stackrel{\sim}{\sim}$ \\
$\stackrel{\sim}{\sigma}$
\end{tabular} & $\begin{array}{l}7 \\
6 \\
6\end{array}$ & 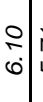 & \begin{tabular}{l|l}
$\hat{\Lambda}$ & 0 \\
$\omega^{\circ}$ & 0 \\
6
\end{tabular} & 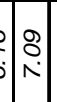 & $\mid$\begin{tabular}{|l|l}
$n$ & 5 \\
0 & 5 \\
0 & 5 \\
0
\end{tabular} & : & $\left|\begin{array}{c}\hat{0} \\
0 \\
0 \\
0\end{array}\right|$ & & con & $\left|\begin{array}{l}\mathfrak{\vartheta} \\
\infty \\
\infty\end{array}\right|$ & & $\begin{array}{l}7 \\
0 \\
0\end{array}$ & 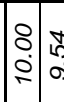 & 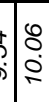 & 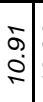 & & & & $\begin{aligned} 4 \\
7\end{aligned}$ \\
\hline 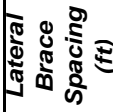 & 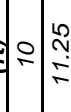 & 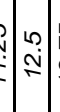 & 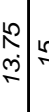 & $\neg$ 뇩 & 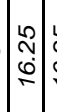 & 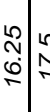 & 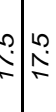 & $\mid$\begin{tabular}{c|}
$n$ \\
1 \\
$\infty$ \\
-1 \\
-1
\end{tabular} & 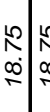 & 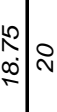 & $\curvearrowright$ & $\curvearrowright$ & 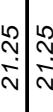 & 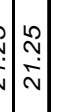 & 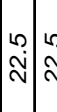 & N & 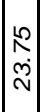 & & 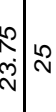 & $\stackrel{\infty}{\sim}$ & & 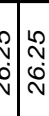 & 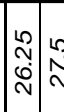 & $\stackrel{?}{\stackrel{n}{N}}$ & $\stackrel{?}{\stackrel{n}{\sim}}$ & 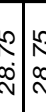 & & & b \\
\hline 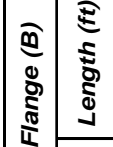 & o) & 8 & & $\circ: 8$ & 6 & เి & $8 \curvearrowright$ & 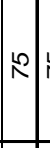 & & L & $\infty$ & $\underset{\sigma}{\infty}$ & $\begin{array}{lll}\infty & \infty & \infty\end{array}$ & $B \vec{i}$ & & 8 & ڤి & & î & & & 1) & ஜ) & & 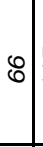 & & & & $\mathbb{N})$ \\
\hline 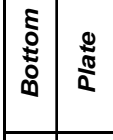 & 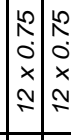 & 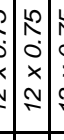 & & 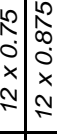 & $\mid \begin{array}{c}n \\
\infty \\
0 \\
0 \\
x \\
-1 \\
-1\end{array}$ & & 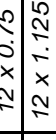 & 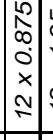 & 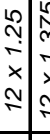 & 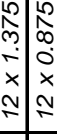 & 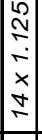 & 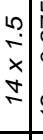 & 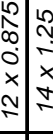 & 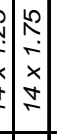 & 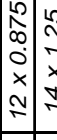 & 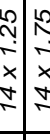 & 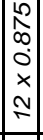 & 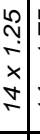 & 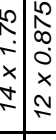 & 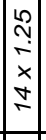 & $\begin{array}{l}0 \\
- \\
x \\
x \\
\end{array}$ & : & 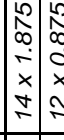 & 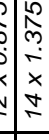 & 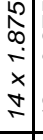 & 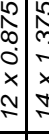 & \begin{tabular}{|l}
0 \\
0 \\
0 \\
-1 \\
$x$ \\
-1 \\
-1
\end{tabular} & 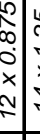 & \\
\hline 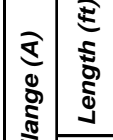 & & . & & ' & ' & ' & ' & ' & ' & '. & & $\begin{array}{l}0 \\
-1\end{array}$ & & 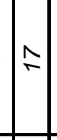 & & 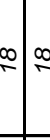 & & & ㄱ| & & & & $\hat{N}$ & & $\approx$ & 1 & $\stackrel{\infty}{\sim}$ & & $\Delta$ \\
\hline 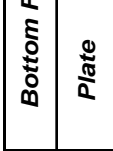 & & ' & & ' 1 & . & ' & ' & . & ' & & & 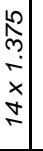 & & $\mid \begin{array}{c}2 \\
\sim \\
-1 \\
-1 \\
x \\
-1 \\
-1\end{array}$ & & 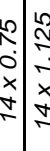 & & & & & & & 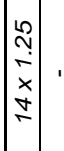 & & $\begin{array}{l}1 \\
-1 \\
x \\
x \\
-7\end{array}$ & & 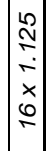 & & \\
\hline $\begin{array}{l}\widehat{\Xi} \\
\text { §̊ } \\
\text { ș }\end{array}$ & 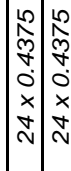 & 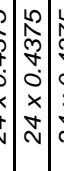 & 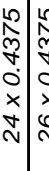 & 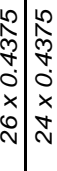 & 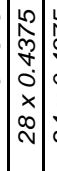 & 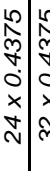 & 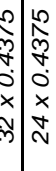 & 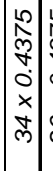 & 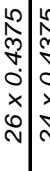 & 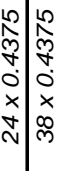 & 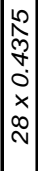 & 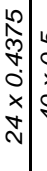 & 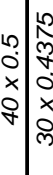 & 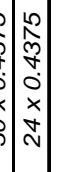 & 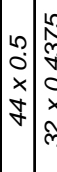 & 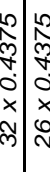 & 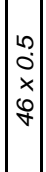 & 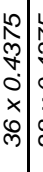 & 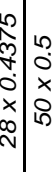 & $\mid \begin{array}{l}0 \\
0 \\
0 \\
x \\
\infty \\
\infty \\
\infty\end{array}$ & 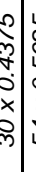 & 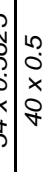 & 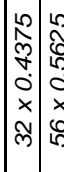 & 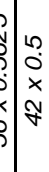 & 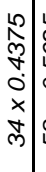 & 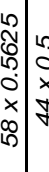 & $\begin{array}{l}1 \\
0 \\
0 \\
0 \\
6 \\
0 \\
n\end{array}$ & 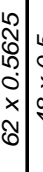 & \\
\hline $\begin{array}{l}\frac{8}{5} \\
\frac{\pi}{4} \\
\frac{\pi}{5} \\
\frac{2}{5}\end{array}$ & 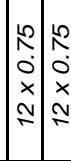 & 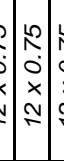 & 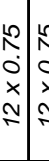 & 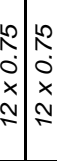 & $\mid$\begin{tabular}{l}
$n$ \\
2 \\
0 \\
$x$ \\
$x$ \\
$\sim$ \\
\hdashline
\end{tabular} & 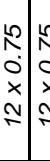 & $\begin{array}{ll}0 & \\
0 & \\
x \\
x \\
-1 \\
\end{array}$ & 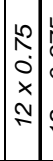 & 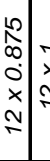 & 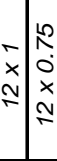 & $\begin{array}{l}-7 \\
x \\
-1 \\
-1\end{array}$ & $\begin{array}{l}4 \\
x \\
7 \\
7\end{array}$ & 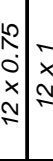 & 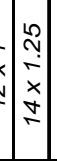 & 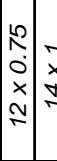 & 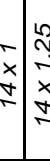 & 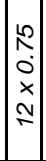 & $\begin{array}{l}7 \\
7 \\
7 \\
7\end{array}$ & 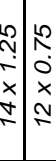 & 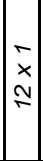 & 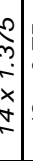 & 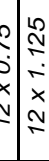 & 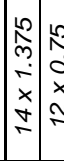 & 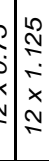 & $\begin{array}{l}\stackrel{n}{0} \\
\hat{n} \\
-\vec{x} \\
x \\
- \\
\rightarrow\end{array}$ & 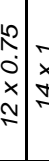 & $\left.\mid \begin{array}{l}\sim \\
\sim \\
\sim \\
x \\
0 \\
-1\end{array}\right]$ & & \\
\hline 9 & 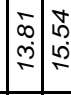 & 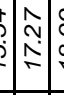 & 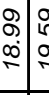 & 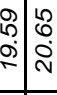 & $\begin{array}{l}0 \\
0 \\
2 \\
2\end{array}$ & 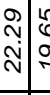 & 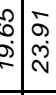 & $\left|\begin{array}{l}0 \\
0 \\
2 \\
\end{array}\right|$ & 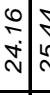 & 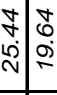 & 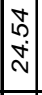 & 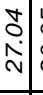 & 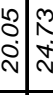 & 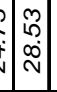 & \begin{tabular}{l|l}
$\infty$ & \\
0 & 0 \\
0 & 0 \\
& $\delta$
\end{tabular} & 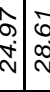 & $\mid \begin{array}{l}0 \\
0 \\
\dot{v} \\
\end{array}$ & 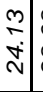 & 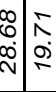 & 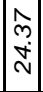 & & ț & 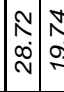 & 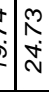 & $\begin{array}{l}\hat{N} \\
\substack{0 \\
N}\end{array}$ & 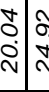 & $\mid \begin{array}{l}\infty \\
\infty \\
0 \\
\infty \\
\sim\end{array}$ & & \\
\hline 离 & \& & & (n) & 88 & 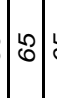 & ¿ & Q & $\mathrm{M}$ & $\stackrel{5}{5}$ & $2 \infty$ & 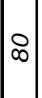 & $\infty$ & $\infty$ & $\infty$ & & $a$ & $\sigma^{\prime}$ & & เ) & & & & $\begin{array}{l}0 \\
-1 \\
-1\end{array}$ & 4 & 이 & $\underset{7}{7}$ & $\frac{5}{7}$ & & \\
\hline
\end{tabular}



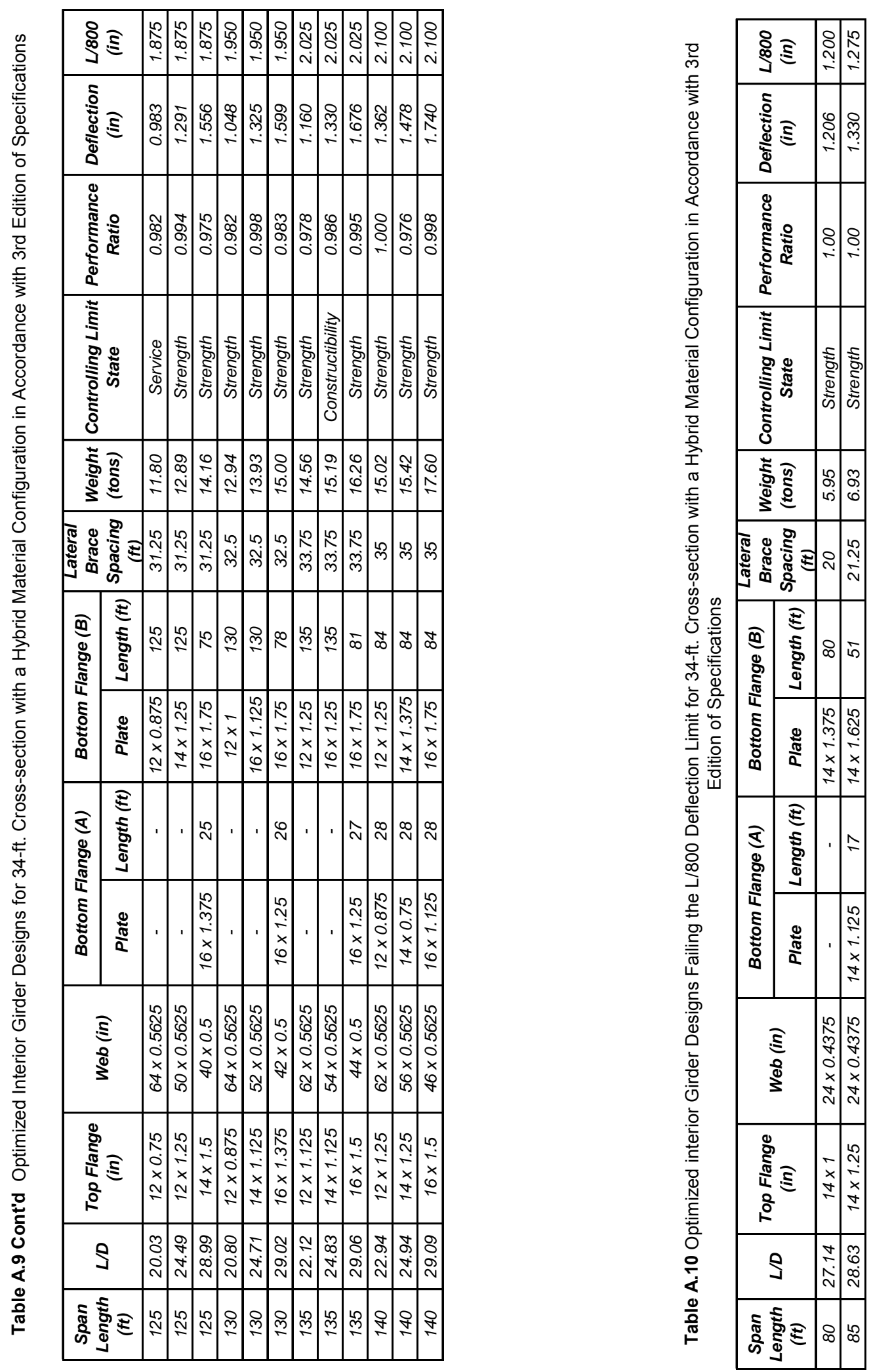


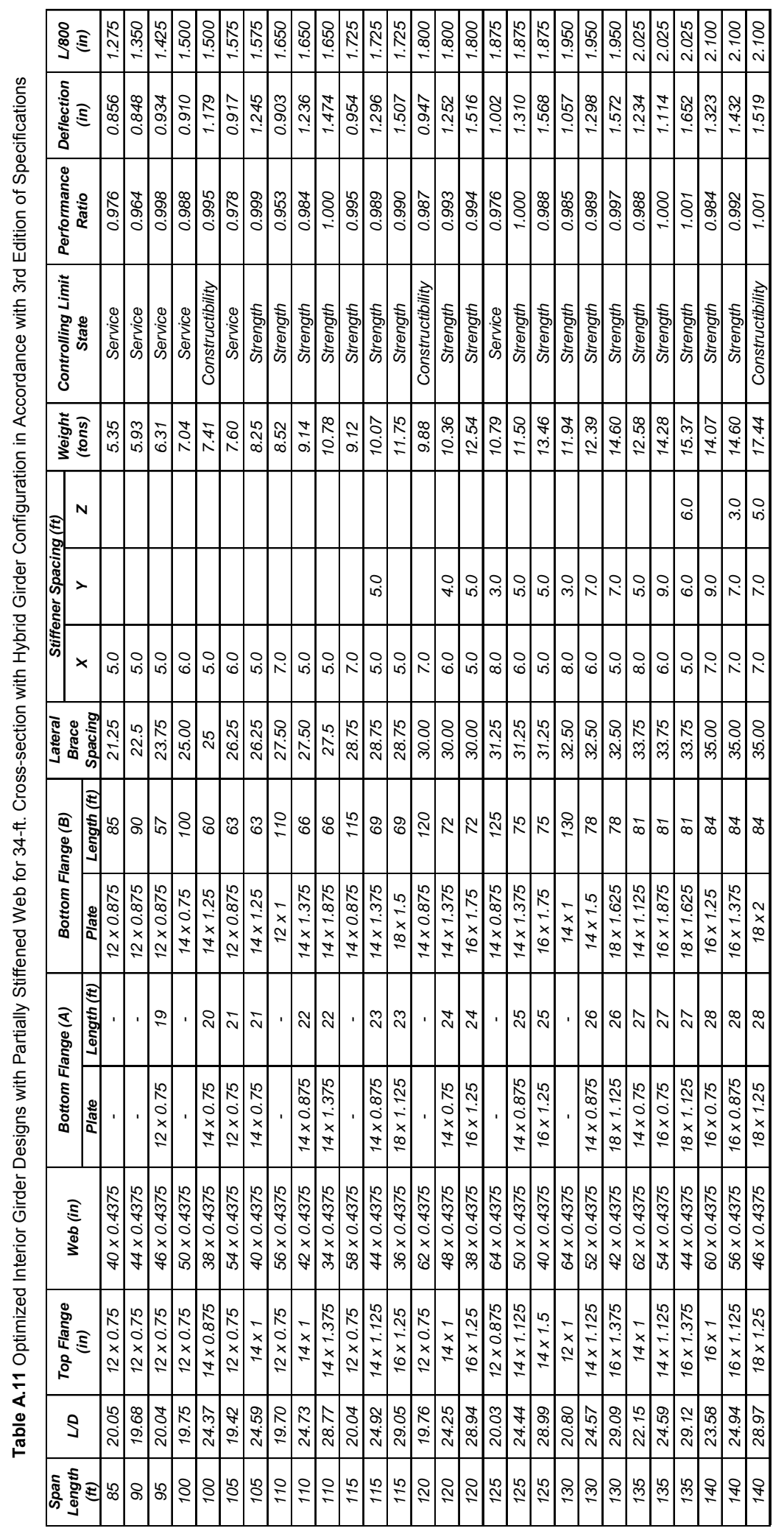




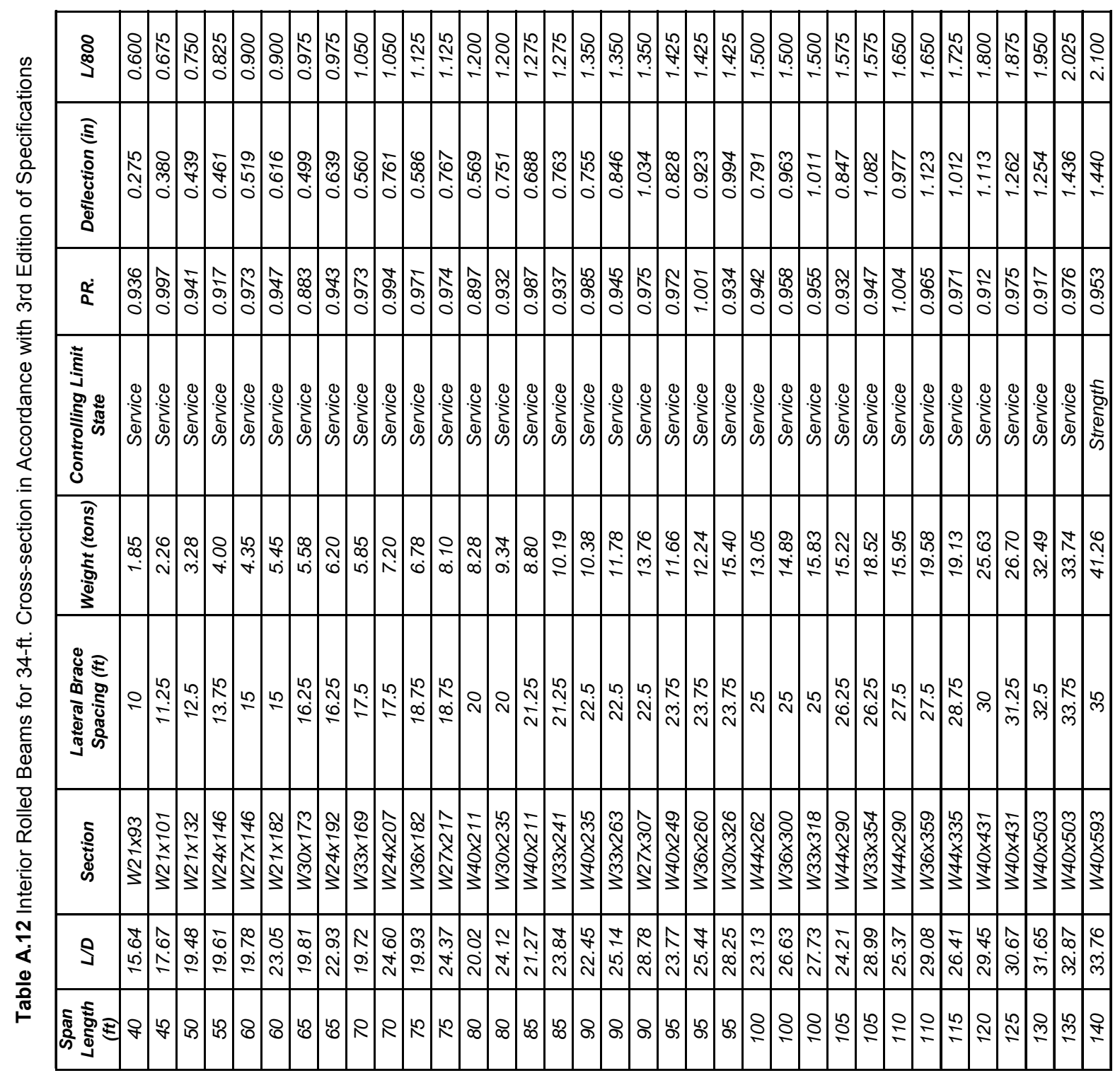




\begin{tabular}{|c|c|c|c|c|c|c|c|c|c|c|c|c|c|c|c|c|c|c|c|c|c|c|c|c|c|c|c|c|c|c|c|c|}
\hline$\stackrel{\Phi}{\Xi}$ & 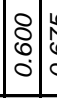 & $\begin{array}{l}0 \\
\vdots \\
\vdots \\
\vdots\end{array}$ & & & & & 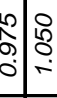 & 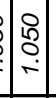 & 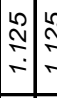 & 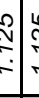 & 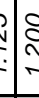 & id & 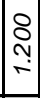 & \begin{tabular}{c}
0 \\
\multirow{-}{*}{}
\end{tabular} & $\curvearrowright$ & & & 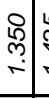 & 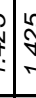 & & - & & & - & & $\begin{array}{l}0 \\
0 \\
0 \\
-i\end{array}$ & & & $\mid \begin{array}{c}\stackrel{N}{N} \\
-i\end{array}$ & & & 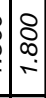 \\
\hline 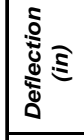 & 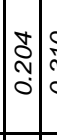 & & & $\mid \begin{array}{l}0 \\
0 \\
6 \\
0 \\
\end{array}$ & & & 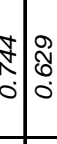 & & & & & & & & & $\begin{array}{l}\mathbb{N} \\
\hat{N} \\
0\end{array}$ & $\mid \begin{array}{c}\overrightarrow{\hat{O}} \\
0 \\
-i\end{array}$ & & & & & & & & & $\left|\begin{array}{c}0 \\
0 \\
\infty \\
0 \\
0\end{array}\right|$ & & & & & & \\
\hline 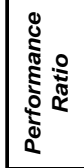 & $\mid \begin{array}{l}0 \\
0 \\
0 \\
0 \\
0\end{array}$ & & & & & & & & & & & & & & & & $\mid$ & & & & & & & & & & & & & & & \\
\hline 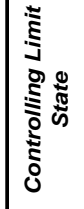 & 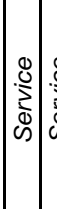 & & & & 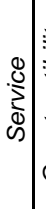 & 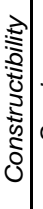 & 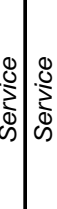 & $\mid$ & & & & & & & & 岕 & & & & & 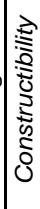 & & & & & 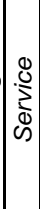 & & & 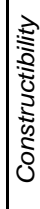 & & & \\
\hline 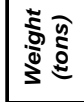 & $\left.\mid \begin{array}{l}0 \\
\delta \\
0 \\
0 \\
-i\end{array}\right]$ & 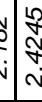 & \begin{tabular}{|ll}
$\hat{\alpha}$ \\
$\stackrel{\alpha}{\alpha}$
\end{tabular} & 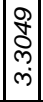 & & 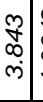 & 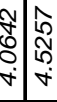 & 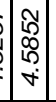 & 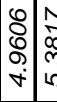 & 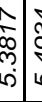 & 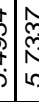 & \begin{tabular}{l}
8 \\
\multirow{2}{7}{} \\
0 \\
10
\end{tabular} & $\begin{array}{l}0 \\
0 \\
0\end{array}$ & $\begin{array}{l}0 \\
\vdots \\
8 \\
6 \\
\end{array}$ & & 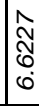 & & 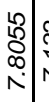 & & 6 & న్ & & & $\begin{array}{l}f \\
\text { f. } \\
f^{\circ}\end{array}$ & & $\left|\begin{array}{l}\infty \\
\tilde{D} \\
\sim \\
\sim \\
\end{array}\right|$ & & & $\begin{array}{l}7 \\
\text { m } \\
\text { o }\end{array}$ & & & \\
\hline 类 & & & & & & & 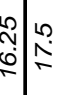 & & & 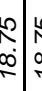 & & $\stackrel{\curvearrowright}{2}$ & & 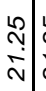 & & \begin{tabular}{l}
$n$ \\
\multirow{N}{N}{}
\end{tabular} & & 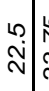 & & 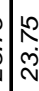 & & & & 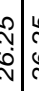 & & $\stackrel{\stackrel{L}{0}}{\stackrel{2}{N}}$ & $\stackrel{\sim}{\sim}$ & & & & & \\
\hline $\begin{array}{l}\overline{\mathbf{m}} \\
\mathrm{g}\end{array}$ & & & & 8 & : & ๑) & ৫) & $\approx$ & & 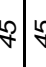 & $f \infty$ & & $\stackrel{\infty}{\sigma}$ & $\begin{array}{l}\infty \\
\infty\end{array}$ & & & 离 & ம் & & & & & & 8 & & 8 & 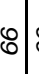 & & 8 & & & $N \wedge$ \\
\hline 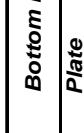 & 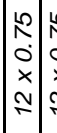 & 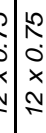 & & & 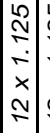 & 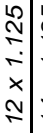 & 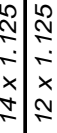 & 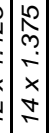 & 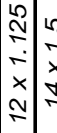 & & & $\begin{array}{l}0 \\
\sim \\
\dot{X} \\
X \\
\end{array}$ & \begin{tabular}{l}
$\tilde{x}$ \\
$\times$ \\
\multirow{-}{-}{}
\end{tabular} & 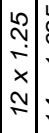 & & 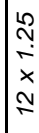 & 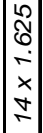 & 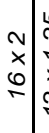 & 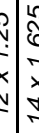 & \begin{tabular}{|l}
$v$ \\
$x$ \\
$x$ \\
0 \\
-1
\end{tabular} & 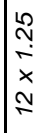 & $\left.\mid \begin{array}{c}n \\
0 \\
0 \\
-i \\
x \\
- \\
-\end{array}\right]$ & $\begin{array}{c}10 \\
\infty \\
0 \\
-1 \\
x \\
0 \\
0\end{array}$ & 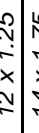 & & 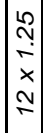 & $\begin{array}{l}0 \\
- \\
- \\
x \\
\sigma \\
\end{array}$ & & $\begin{array}{l}\qquad \\
- \\
-1 \\
x \\
-1\end{array}$ & & 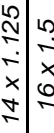 & 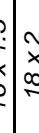 \\
\hline 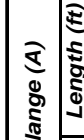 & & & & & & & & $\underset{7}{\nabla}$ & & $\begin{array}{ll}\mathrm{A} \\
\mathrm{a}\end{array}$ & & & $\stackrel{\sim}{-1}$ & & $\rightarrow 1$ & & $\stackrel{\infty}{-1}$ & $\underset{\sim}{\infty}$ & & & & & & ה & & $\approx$ & $\mathbb{N}$ & & $\stackrel{\infty}{N}$ & & & 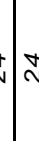 \\
\hline 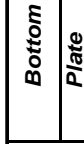 & & & & & & & & $\left|\begin{array}{l}n \\
0 \\
0 \\
x \\
-1 \\
-1\end{array}\right|$ & & & & & & & & & $\left|\begin{array}{c}1 \\
0 \\
0 \\
0 \\
x \\
\quad \\
-1 \\
\mid\end{array}\right|$ & $\begin{array}{l}-1 \\
x \\
0 \\
-1\end{array}$ & & & $\begin{array}{l}2 \\
0 \\
0 \\
x \\
x \\
\end{array}$ & 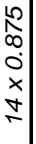 & $\begin{array}{l}-1 \\
x \\
\infty \\
\infty\end{array}$ & 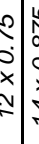 & & 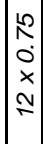 & $\infty$ & & $\left\{\begin{array}{l}\qquad \\
0 \\
0 \\
0 \\
x \\
x \\
-1\end{array}\right.$ & & 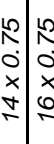 & 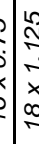 \\
\hline 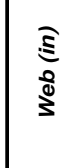 & 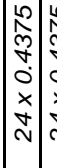 & 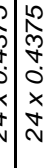 & 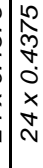 & 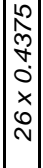 & 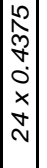 & 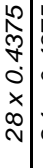 & 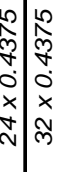 & 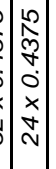 & 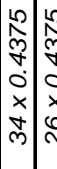 & 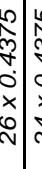 & & & 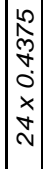 & 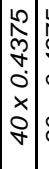 & $\begin{array}{l}0 \\
0 \\
0 \\
0 \\
0 \\
5\end{array}$ & 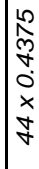 & 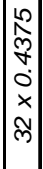 & 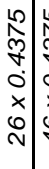 & 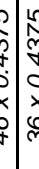 & $\begin{array}{l}0 \\
0 \\
y \\
\vdots \\
x \\
x \\
0 \\
0\end{array}$ & $\begin{array}{l}n \\
0 \\
0 \\
0 \\
0 \\
0\end{array}$ & & & $\begin{array}{l}0 \\
0 \\
\times \\
\text { v } \\
0\end{array}$ & & $\begin{array}{l}0 \\
0 \\
0 \\
x \\
6 \\
6 \\
\end{array}$ & & $\begin{array}{l}0 \\
\vdots \\
0 \\
x \\
\vdots \\
y\end{array}$ & 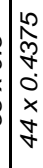 & & & 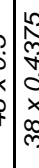 \\
\hline 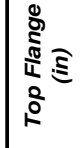 & 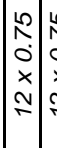 & 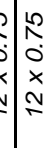 & 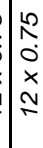 & 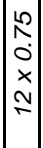 & 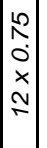 & 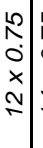 & 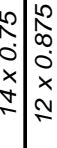 & 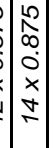 & $\mid$\begin{tabular}{c|c}
0 \\
0 \\
0 \\
0 \\
$x$ \\
$x$ \\
\\
-1 \\
-1
\end{tabular} & 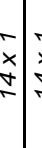 & $\begin{array}{l}4 \\
t \\
4 \\
4\end{array}$ & $\begin{array}{l}\vec{x} \\
\underset{7}{ \pm}\end{array}$ & 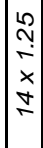 & 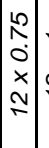 & & 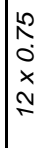 & $\begin{array}{l}\vec{x} \\
x \\
\mathbb{A} \\
\end{array}$ & 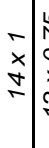 & $\begin{array}{l}? \\
\dot{b} \\
x \\
\text { val }\end{array}$ & $\begin{array}{l}-1 \\
x\end{array}$ & $\begin{array}{l}\stackrel{\kappa}{2} \\
0 \\
x\end{array}$ & & & $\begin{array}{l}0 \\
0 \\
0 \\
x \\
0\end{array}$ & $\begin{array}{l}x \\
x \\
y\end{array}$ & 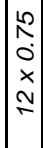 & & & $\begin{array}{l}-1 \\
x \\
y \\
y\end{array}$ & & 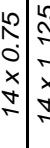 & 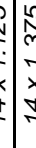 \\
\hline$\sqrt{ }$ & $\begin{array}{c}0 \\
0 \\
0 \\
\dot{m} \\
-1 \\
-1\end{array}$ & 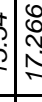 & $\begin{array}{l}\text { Li } \\
\infty \\
\infty \\
\infty\end{array}$ & $\mid \begin{array}{l}0 \\
b \\
\sigma \\
-1 \\
\end{array}$ & 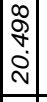 & 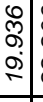 & 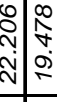 & 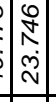 & 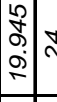 & $\stackrel{2}{2}$ & 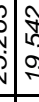 & 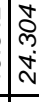 & \begin{tabular}{|c|}
$\hat{0}$ \\
$\dot{0}$ \\
$\dot{0}$ \\
\end{tabular} & 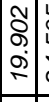 & & \begin{tabular}{|l}
$\infty$ \\
\multirow{L}{0}{} \\
0 \\
0
\end{tabular} & \begin{tabular}{|l}
0 \\
0 \\
0 \\
$\dot{d}$ \\
\\
\end{tabular} & 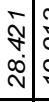 & & & & & & & & 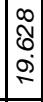 & & & 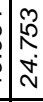 & & 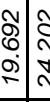 & 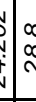 \\
\hline & & & & & & & 8 & & & & & & & & & & & & & & & & & & & & & & & & స్ & \\
\hline
\end{tabular}




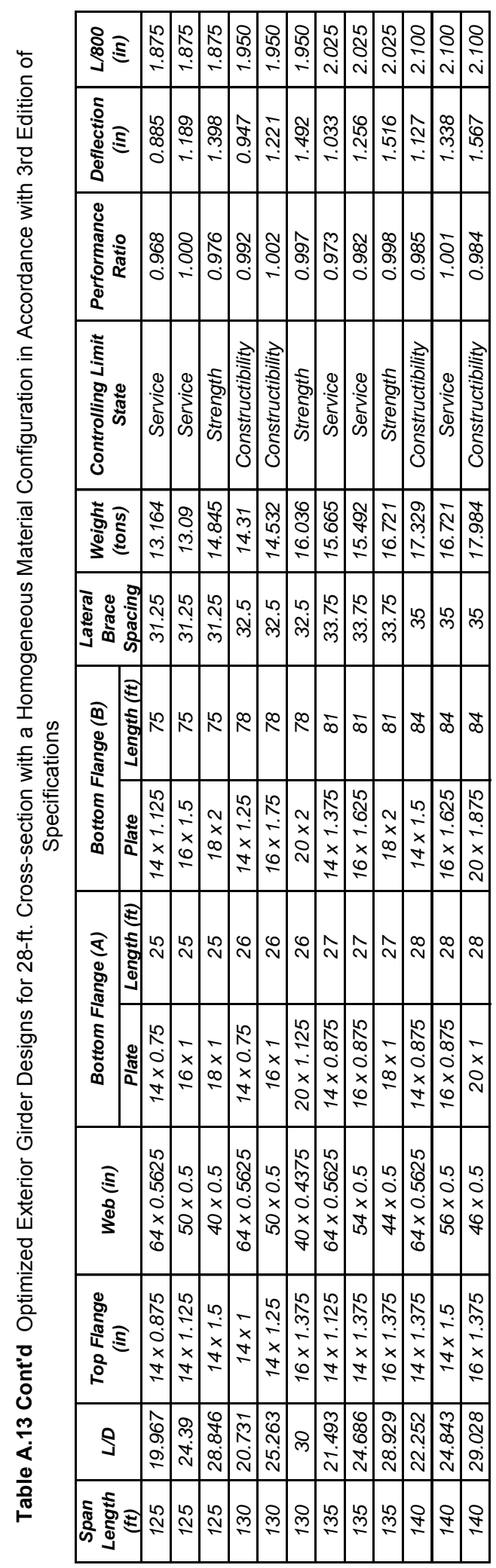




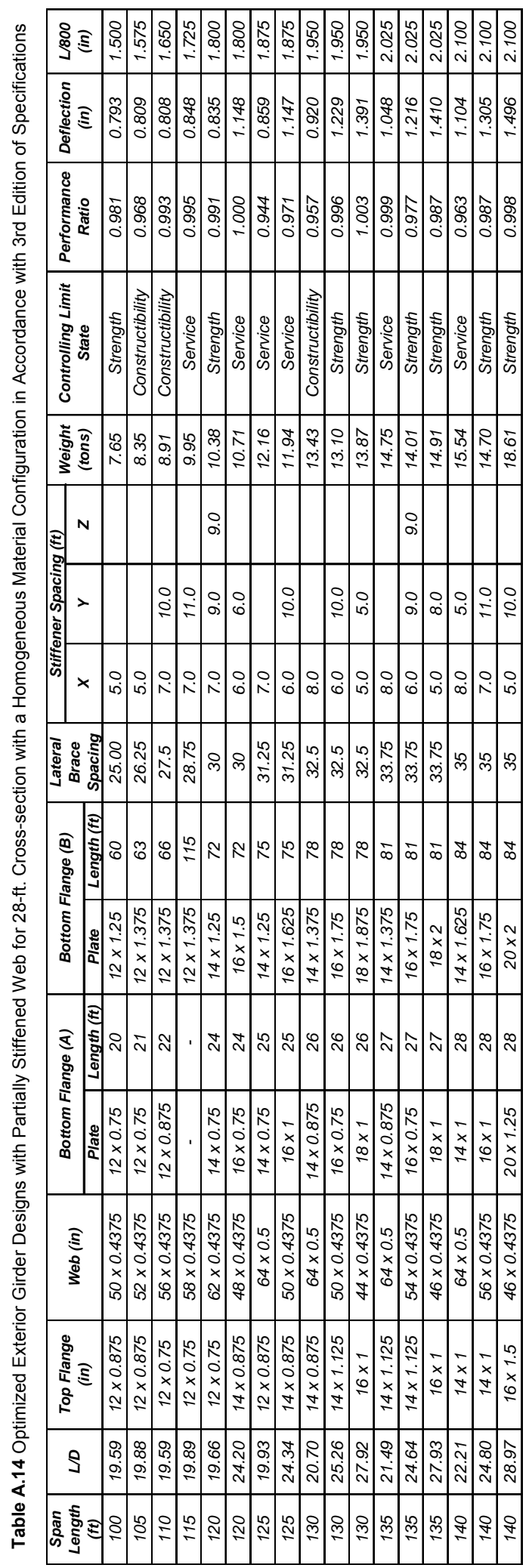




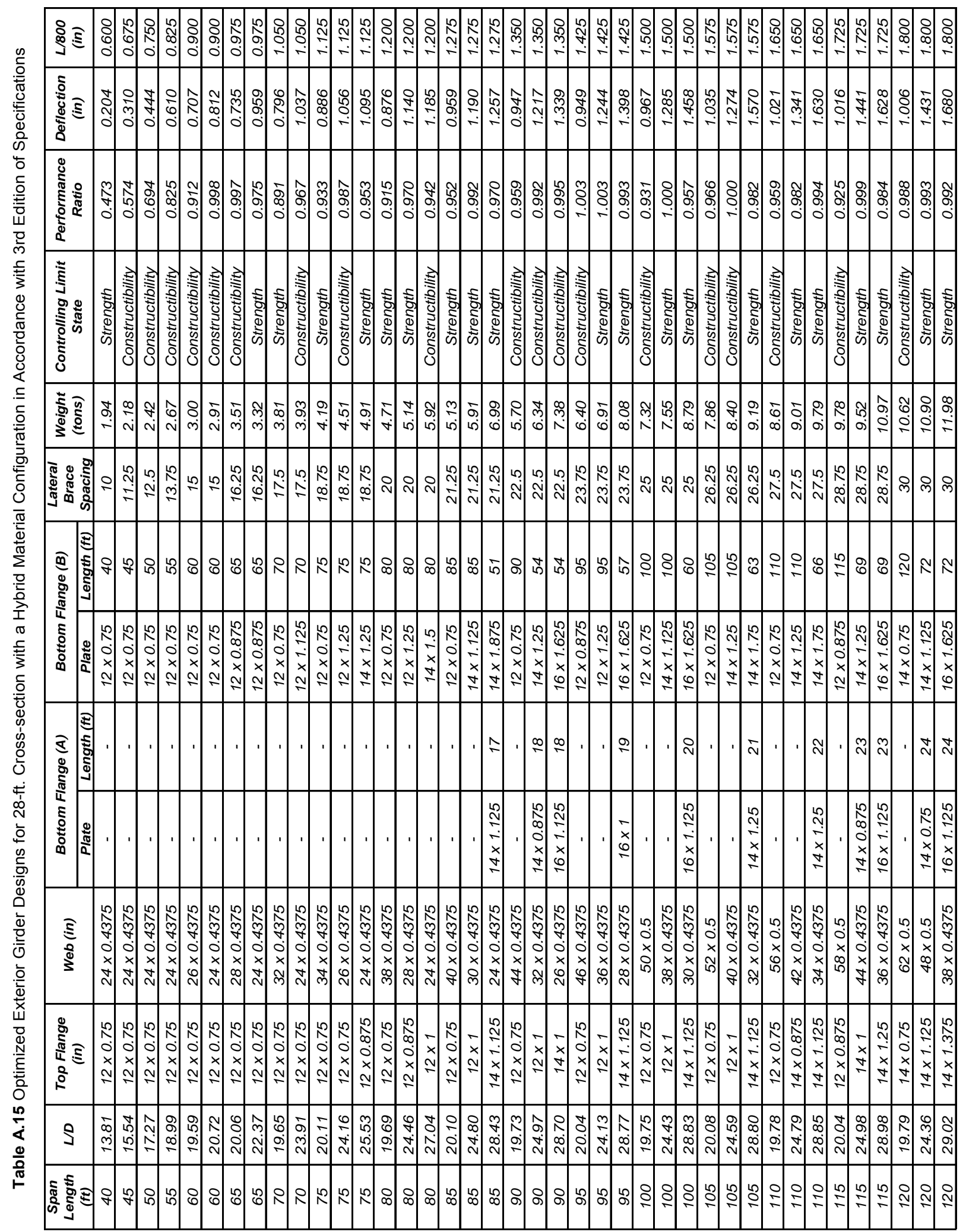




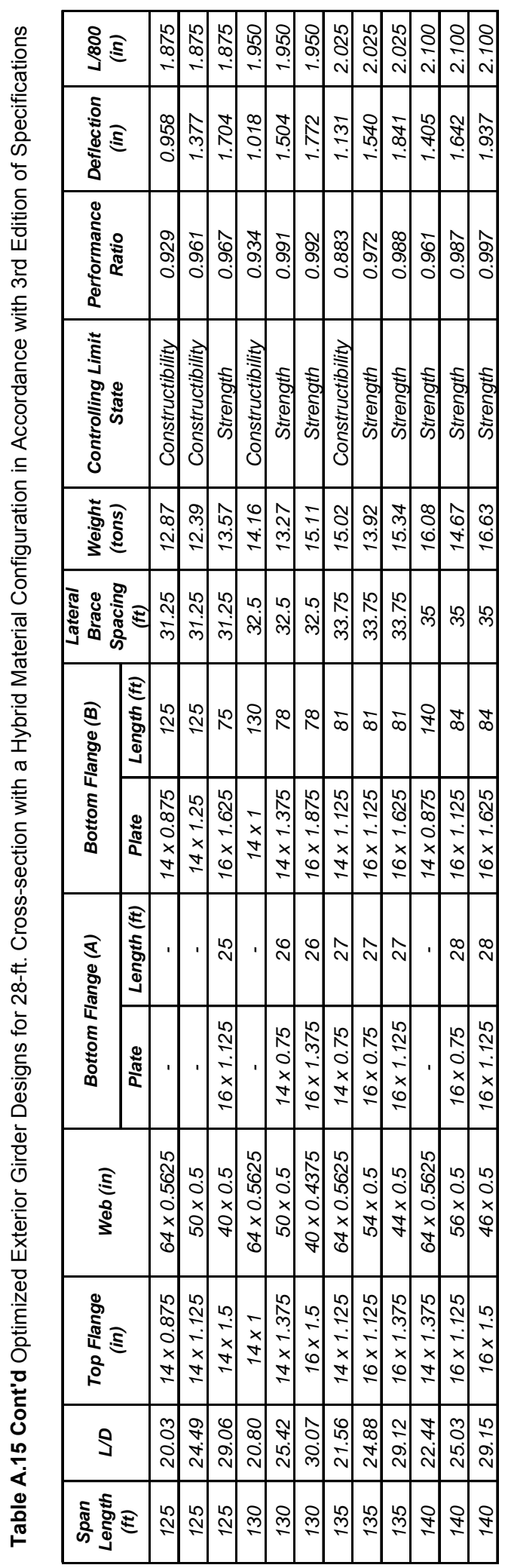



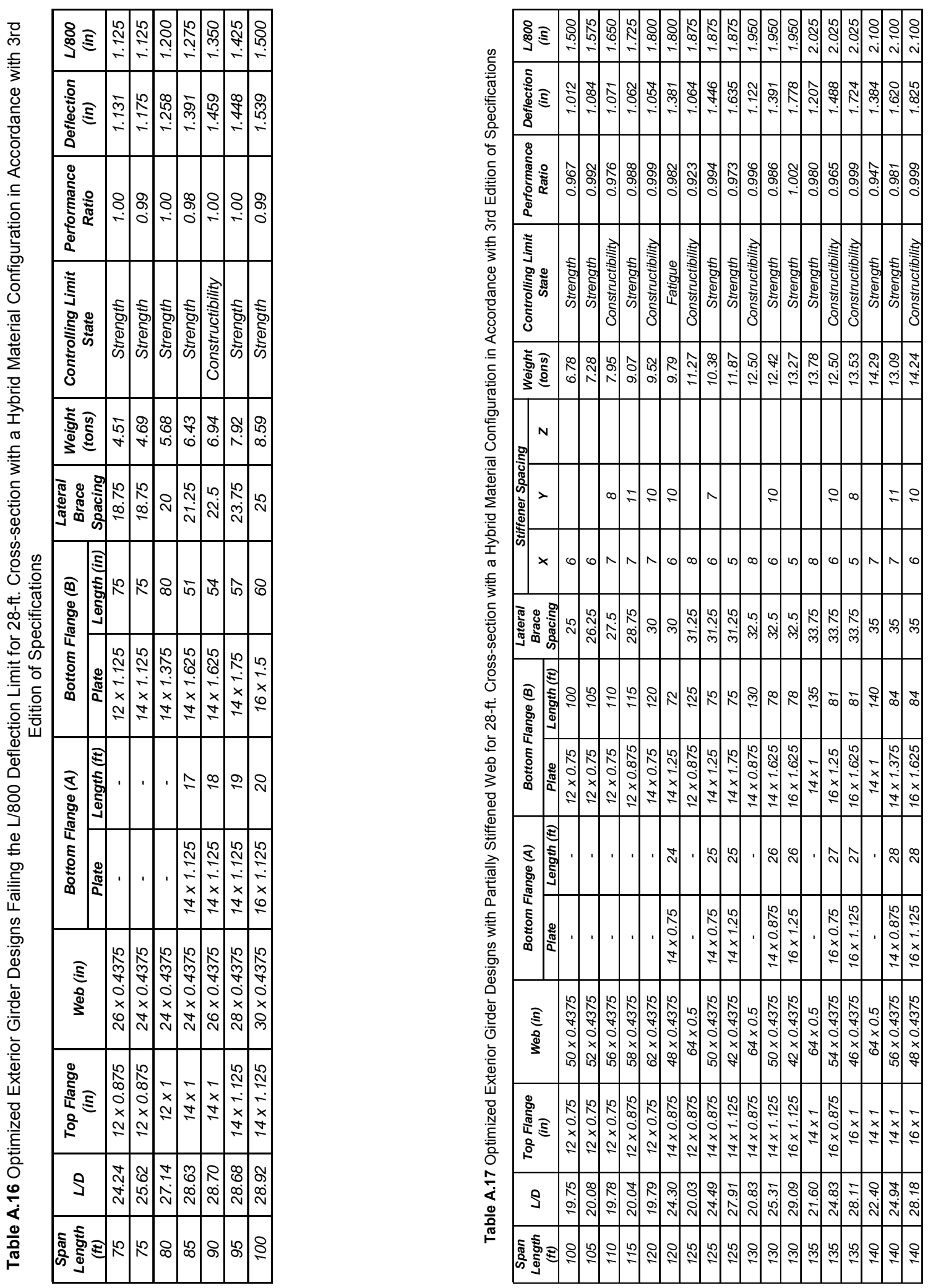


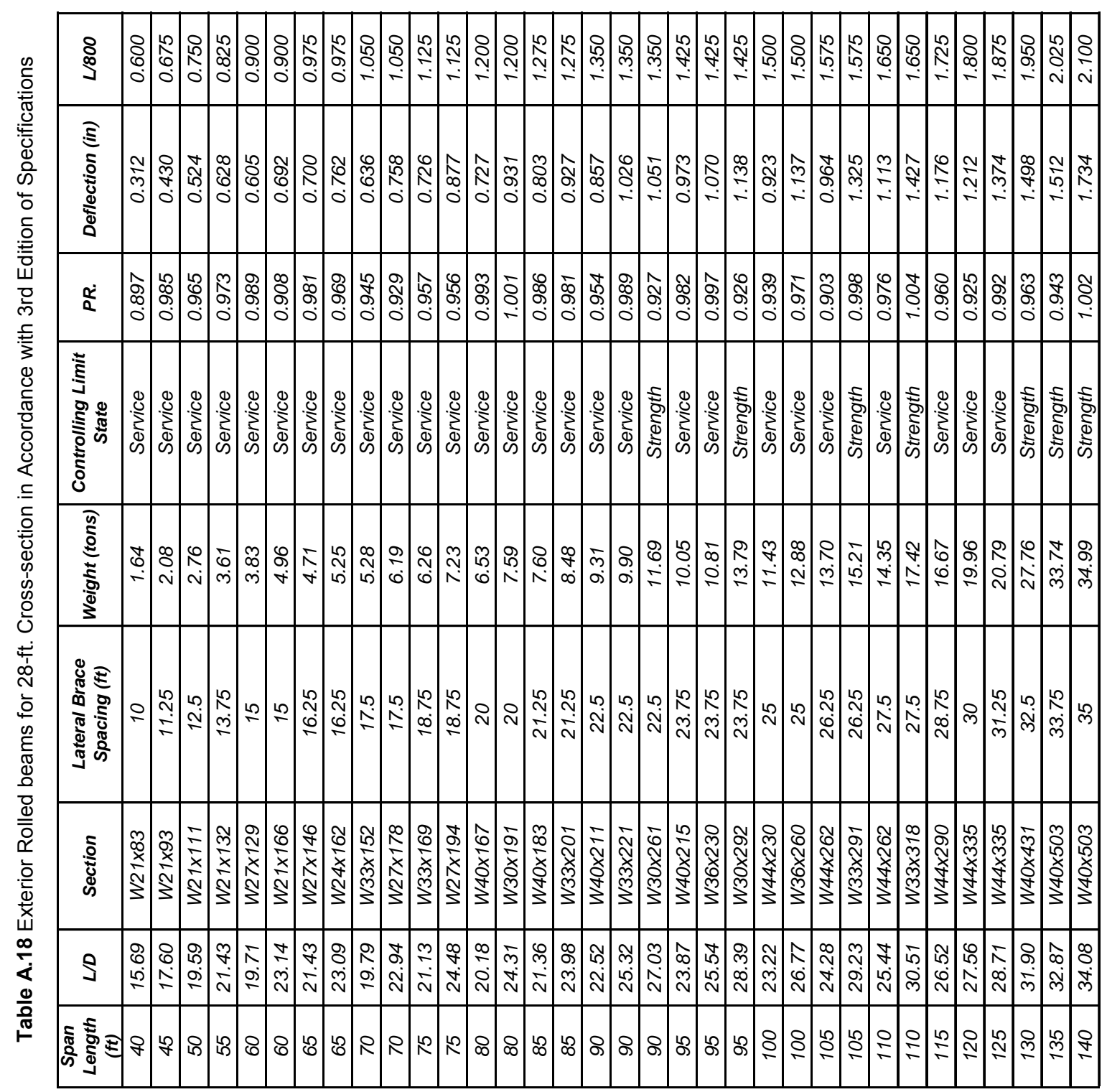




\begin{tabular}{|c|c|c|c|c|c|c|c|c|c|c|c|c|c|c|c|c|c|c|c|c|c|c|c|c|c|c|c|c|c|c|c|c|c|}
\hline 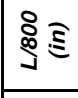 & \begin{tabular}{|l|}
8 \\
0 \\
0 \\
0
\end{tabular} & $\mid$ & $\begin{array}{ll}0 \\
\\
0 \\
0\end{array}$ & 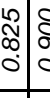 & \begin{tabular}{l}
$:$ \\
$:$ \\
\hdashline \\
\end{tabular} & 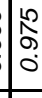 & $\left|\begin{array}{l}1 \\
0 \\
0 \\
0 \\
0\end{array}\right|$ & 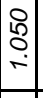 & $\begin{array}{l}0 \\
0 \\
-1 \\
-1\end{array}$ & 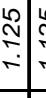 & تָ & 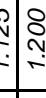 & $\underset{\substack{\sim\\
}}{\mathcal{H}}$ & & & 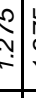 & $\begin{array}{ccc}0 \\
\end{array}$ & 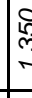 & 岕 & . & . & & 象 & $\mid$ & 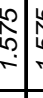 & 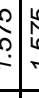 & & $\begin{array}{l}5 \\
\stackrel{5}{0} \\
-1\end{array}$ & $\begin{array}{l}0 \\
. \\
0 \\
-i\end{array}$ & 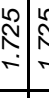 & & & \begin{tabular}{c|c}
8 & 8 \\
$\infty$ & 0 \\
$-i$ & $\infty$ \\
$-i$
\end{tabular} \\
\hline 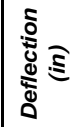 & 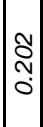 & $\mid$ & & \begin{tabular}{l|l}
0 & \\
6 & 5 \\
$\vdots$ & 5 \\
0 &
\end{tabular} & & d. & $\mid \begin{array}{l}\tilde{N} \\
0 \\
0 \\
0\end{array}$ & $\mid$ & & & 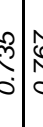 & $\begin{array}{l}0 \\
0 \\
0 \\
0 \\
0 \\
0\end{array}$ & ז. & & $\begin{array}{l}0 \\
0 \\
0\end{array}$ & & & & & $\begin{array}{l}\text { ஜ } \\
6 \\
0 \\
0\end{array}$ & & & & $\begin{array}{l}0 \\
\vdots \\
0 \\
0\end{array}$ & & & & 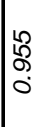 & & & & $\mid$ & 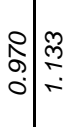 \\
\hline 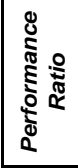 & $\begin{array}{l}0 \\
0 \\
0 \\
0\end{array}$ & & & & & & & & & & & & & & ○。 & & & & & & & & & & & & 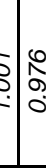 & & & 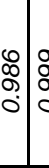 & & & 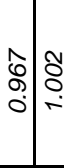 \\
\hline 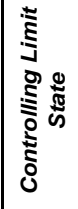 & & & & & & 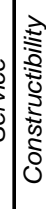 & & & 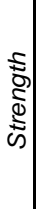 & & & 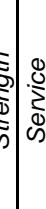 & Dे & 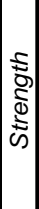 & & & $\tilde{n}$ & & $\stackrel{\Xi}{\omega}$ & 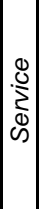 & $\begin{array}{c}0 \\
\bar{\omega} \\
\omega\end{array}$ & & 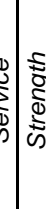 & 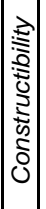 & & & & $\bar{\omega}$ & 志 & ๗ & & $\mid$ & \\
\hline 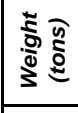 & $\mid \begin{array}{l}0 \\
0 \\
0 \\
-i \\
-1\end{array}$ & 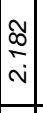 & & 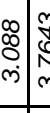 & 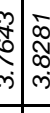 & 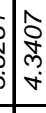 & 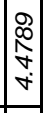 & \begin{tabular}{|l|}
$\mid$ \\
$\tilde{y}$ \\
0 \\
$\dot{\sigma}$ \\
\end{tabular} & $\begin{array}{l}\hat{y} \\
\hat{\jmath} \\
\dot{+} \\
\end{array}$ & 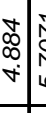 & 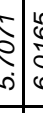 & 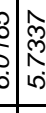 & $\begin{array}{l}\infty \\
0 \\
7 \\
6 \\
\end{array}$ & \begin{tabular}{|l}
$\hat{1}$ \\
0 \\
\end{tabular} & 柋 & 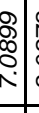 & 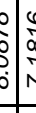 & & \begin{tabular}{l}
0 \\
$\vdots$ \\
\multirow{2}{*}{} \\
0
\end{tabular} & 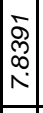 & \begin{tabular}{c|c}
0 \\
0 \\
0 \\
0 \\
$\infty$ \\
$\infty$
\end{tabular} & 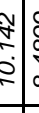 & 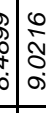 & \begin{tabular}{|l|}
0 \\
0 \\
0 \\
0 \\
-1 \\
\end{tabular} & 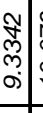 & $\begin{array}{l}0 \\
0 \\
0 \\
0 \\
-1 \\
-1\end{array}$ & 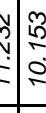 & $\begin{array}{l}\hat{0} \\
8 \\
0 \\
-1 \\
\end{array}$ & 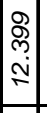 & 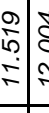 & & $\mid$ & 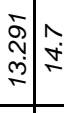 \\
\hline 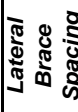 & & 足 & & & & $\begin{array}{l}\stackrel{2}{\Omega} \\
\stackrel{\leftrightarrow}{\circ} \\
-1\end{array}$ & & $\mid \begin{array}{l}0 \\
\\
7\end{array}$ & $\begin{array}{l}n \\
\stackrel{n}{\sim} \\
\rightarrow\end{array}$ & 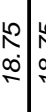 & 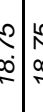 & 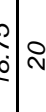 & ฉి & $\stackrel{\sim}{\sim}$ & 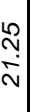 & $\begin{array}{l}\text { N } \\
\text { ה] }\end{array}$ & ה & רo & 邑 & $\left|\begin{array}{c}\stackrel{0}{0} \\
\dot{n} \\
\sim\end{array}\right|$ & $\begin{array}{l}\stackrel{0}{2} \\
\stackrel{2}{\sim} \\
\sim\end{array}$ & & s & $\stackrel{\sim}{\sim}$ & 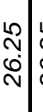 & & & 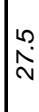 & $\mid \begin{array}{l}0 \\
\stackrel{n}{N} \\
\end{array}$ & 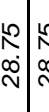 & & o & ঃ \\
\hline 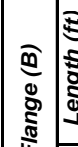 & & \& & & นก) & 8.8 & 8 & ๑ & 尺) & $\approx$ & \&) & & 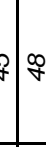 & $\stackrel{\infty}{f}$ & $\stackrel{\infty}{+}$ & & பี) & 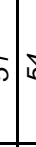 & & & in & in & & $: 8$ & : & ชి & 8 & $: 8$ & 8 & 8 & 8 & 8 & $\curvearrowright$ & $\aleph \approx$ \\
\hline & & 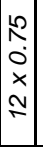 & & 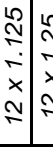 & 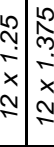 & & & 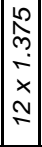 & $\begin{array}{l}\stackrel{2}{0} \\
\underline{-} \\
-i \\
x \\
- \\
-1 \\
\end{array}$ & 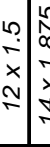 & 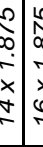 & 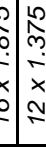 & 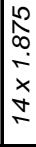 & $\begin{array}{l}2 \\
\infty \\
\infty \\
-1 \\
\times \\
\infty \\
-1\end{array}$ & $\begin{array}{l}0 \\
-\mathrm{i} \\
\mathrm{i}\end{array}$ & 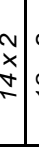 & 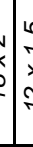 & & 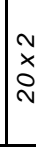 & 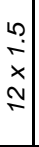 & & 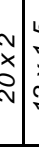 & 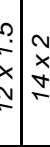 & $\begin{array}{l}v \\
\times \\
\stackrel{2}{ } \\
\sim\end{array}$ & 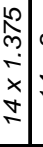 & 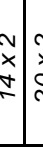 & 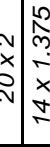 & $\begin{array}{l}\infty \\
\infty \\
\infty \\
\sim \\
\times \\
\times \\
0 \\
-1\end{array}$ & 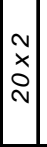 & 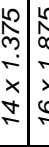 & 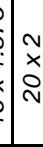 & $\mid \begin{array}{r}0 \\
0 \\
0 \\
-1 \\
x \\
-7 \\
-1 \\
\end{array}$ & 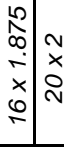 \\
\hline 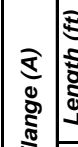 & & & & & ' & & & & $\underset{\sim}{-1}$ & 읜ㄷㄴ & & 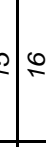 & $\stackrel{0}{-1}$ & $\stackrel{0}{-1}$ & $\mathrm{r}$ & 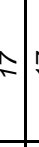 & $4 \div$ & & $\stackrel{\infty}{-\infty}$ & $\rightarrow$ & & & $\stackrel{N}{i}$ & ㄱ. & $\vec{N}$ & & & $\approx$ & & 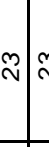 & $\vec{i}$ & $\stackrel{ম}{\sim}$ & $\stackrel{\nabla}{\sim}$ \\
\hline 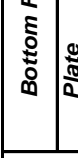 & & & & & ' & & & & $\begin{array}{l}-7 \\
7 \\
-1 \\
-1\end{array}$ & 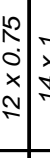 & 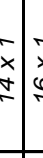 & 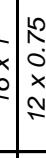 & $\begin{array}{l}-1 \\
x \\
\vdots \\
\exists\end{array}$ & $\begin{array}{c}-7 \\
x \\
0 \\
-1\end{array}$ & & $\begin{array}{l}7 \\
x \\
\vdots \\
\end{array}$ & $\begin{array}{ccc}4 & 5 \\
x & 2 \\
0 & 2\end{array}$ & & & $\mid \begin{array}{l}0 \\
0 \\
\infty \\
0 \\
x \\
x \\
\sim \\
\sim\end{array}$ & \begin{tabular}{l|l}
7 \\
$x$ \\
7 \\
-1
\end{tabular} & 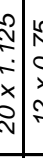 & 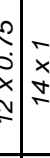 & 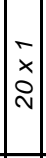 & $\begin{array}{l}5 \\
0 \\
0 \\
\times \\
+ \\
-1\end{array}$ & $\begin{array}{l}4 \\
x \\
x \\
4 \\
4\end{array}$ & 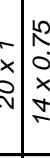 & $\begin{array}{l}10 \\
\infty \\
\infty \\
0 \\
\times \\
0 \\
-1 \\
\end{array}$ & 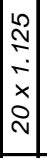 & 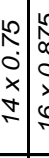 & 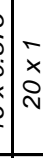 & 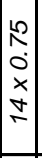 & 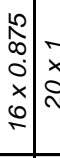 \\
\hline 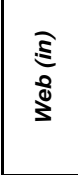 & 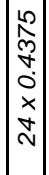 & 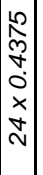 & 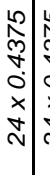 & 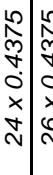 & 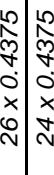 & 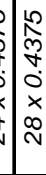 & 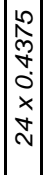 & $\mid \begin{array}{l}0 \\
\hat{0} \\
0 \\
0 \\
0 \\
x \\
0 \\
m\end{array}$ & 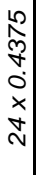 & 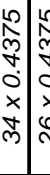 & 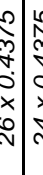 & 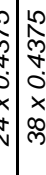 & 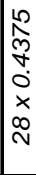 & 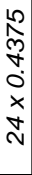 & 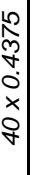 & 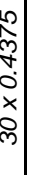 & 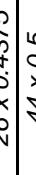 & 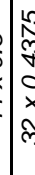 & 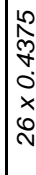 & \begin{tabular}{|l|}
$\mid$ \\
0 \\
0 \\
$x$ \\
0 \\
0 \\
\end{tabular} & 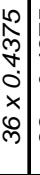 & 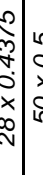 & 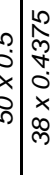 & $\left|\begin{array}{l}\hat{n} \\
\hat{p} \\
\delta \\
0 \\
x \\
\hat{m}\end{array}\right|$ & 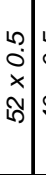 & 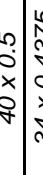 & 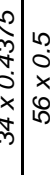 & 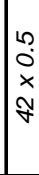 & 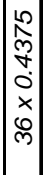 & 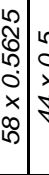 & & $\left|\begin{array}{l}n \\
0 \\
0 \\
0 \\
0 \\
x \\
\mathfrak{1} \\
0\end{array}\right|$ & 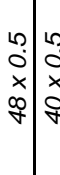 \\
\hline 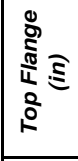 & 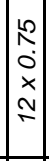 & 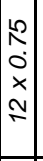 & 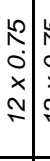 & 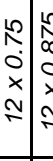 & 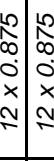 & 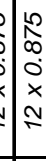 & 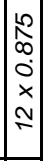 & 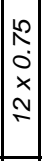 & $\begin{array}{c}0 \\
\infty \\
0 \\
0 \\
x \\
\sim \\
\sim\end{array}$ & 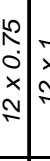 & 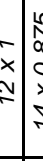 & \begin{tabular}{l|l}
0 & \\
0 & -1 \\
$\vdots$ \\
$x$ \\
$x$ \\
$y$ \\
$y$
\end{tabular} & 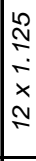 & & & $\begin{array}{l}\text { N } \\
- \\
- \\
\times \\
\times \\
-1 \\
-1\end{array}$ & 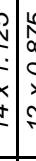 & & 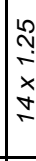 & $\mid \begin{array}{c}n \\
0 \\
\infty \\
0 \\
x \\
\sim \\
\sim \\
-1 \\
\end{array}$ & 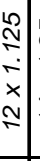 & 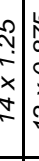 & \begin{tabular}{l|l}
$\Omega$ & \\
0 & -1 \\
0 & $x$ \\
$x$ & $x$ \\
-1 & -1 \\
-1 &
\end{tabular} & 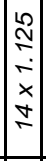 & $\begin{array}{c}\stackrel{0}{ } \\
0 \\
0 \\
0 \\
\times \\
\sim \\
\sim\end{array}$ & $\begin{array}{l}-1 \\
x \\
+ \\
-7 \\
\end{array}$ & 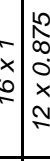 & $\begin{array}{l}-1 \\
x \\
-\end{array}$ & 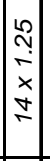 & 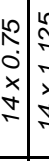 & 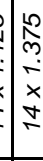 & $\mid$\begin{tabular}{l|} 
\\
-7 \\
$x$ \\
+ \\
-1 \\
\end{tabular} & 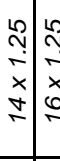 \\
\hline 9 & $\mid \begin{array}{l}m \\
0 \\
0 \\
m \\
-1 \\
-1\end{array}$ & $\mid \begin{array}{l}0 \\
0 \\
5 \\
-1 \\
\end{array}$ & 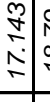 & 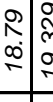 & 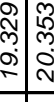 & 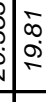 & $\begin{array}{l}0 \\
\infty \\
\infty \\
\dot{v} \\
\end{array}$ & \begin{tabular}{|c|c}
0 \\
0 \\
0 \\
0 \\
-1 \\
\end{tabular} & 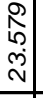 & 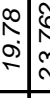 & 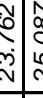 & 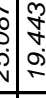 & 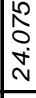 & 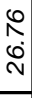 & ه. & 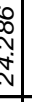 & $\begin{array}{l}\mid \\
0 \\
0 \\
\vdots \\
\vdots\end{array}$ & 0 & $\begin{array}{l}\tilde{Z} \\
\searrow \\
\infty\end{array}$ & $\mid \begin{array}{l}0 \\
0 \\
0 \\
0 \\
\\
\end{array}$ & $\begin{array}{l}\stackrel{2}{1} \\
\stackrel{2}{3} \\
\end{array}$ & 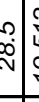 & 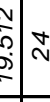 & $\mid \begin{array}{l}0 \\
N \\
\\
\\
\end{array}$ & $\begin{array}{c}0 \\
\infty \\
\infty \\
\text {. } \\
\\
\end{array}$ & 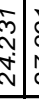 & 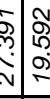 & 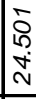 & $\mid \begin{array}{l}\infty \\
\stackrel{n}{\sim} \\
\end{array}$ & 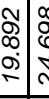 & 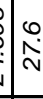 & $\mid \begin{array}{l}n \\
0 \\
0 \\
\vdots \\
\\
\end{array}$ & 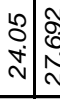 \\
\hline 放 & & \& & 同 & 5 & 88 & 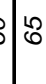 & 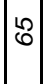 & $\lambda$ & $\curvearrowright$ & 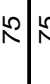 & 5 & 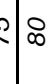 & & & & & & & & 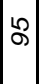 & ᄋ & क) & 8 & ঃి & $\stackrel{2}{2}$ & s. & క్- & & 워 & $\stackrel{\text { Ln }}{7}$ & $\underset{\sim}{\sim}$ & $\stackrel{\overbrace{}}{\sim}$ & \\
\hline
\end{tabular}




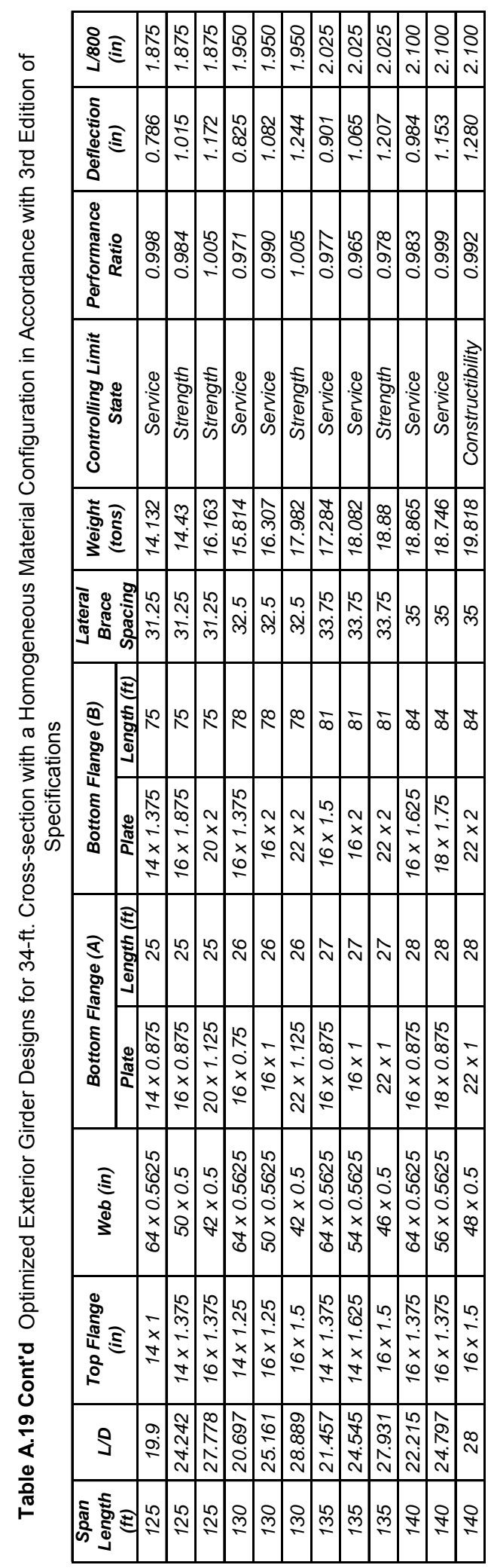




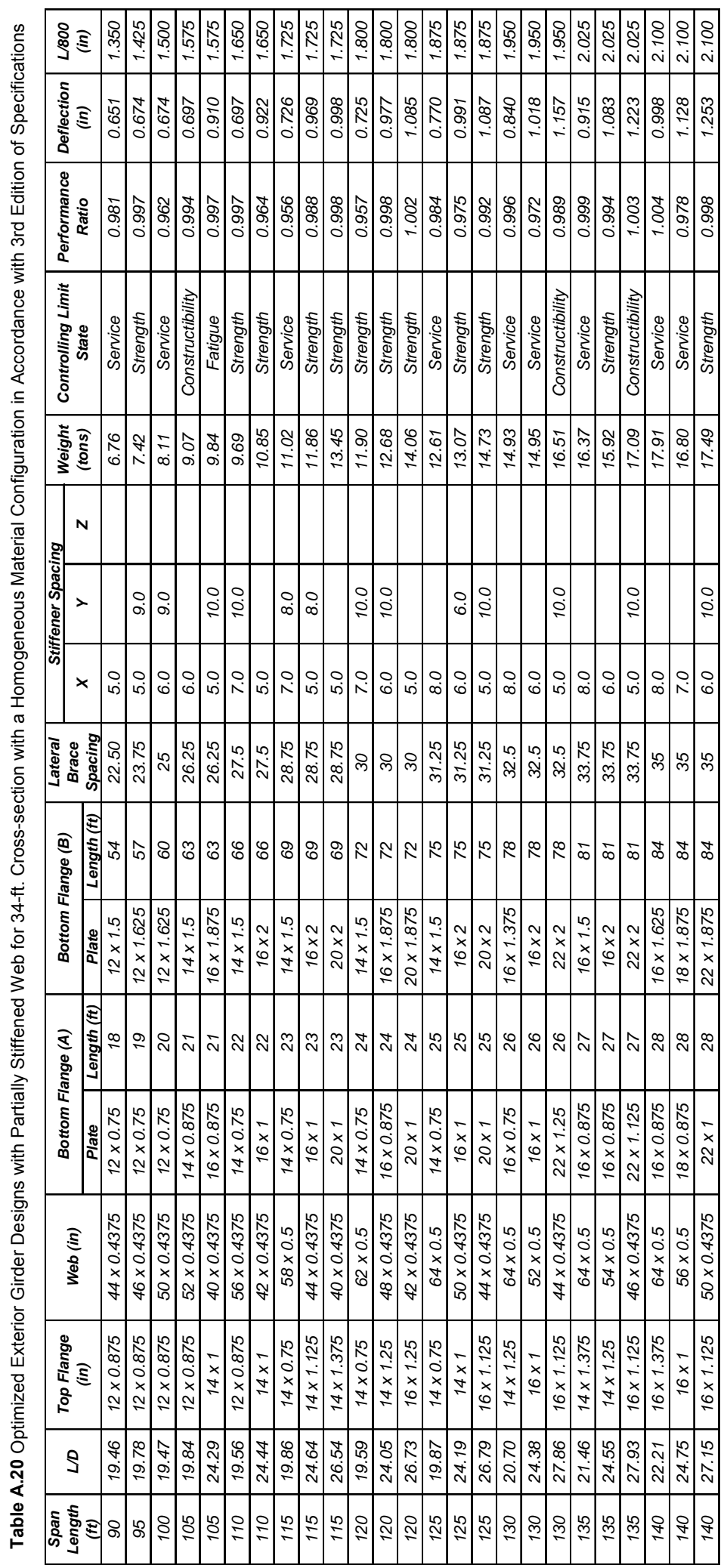




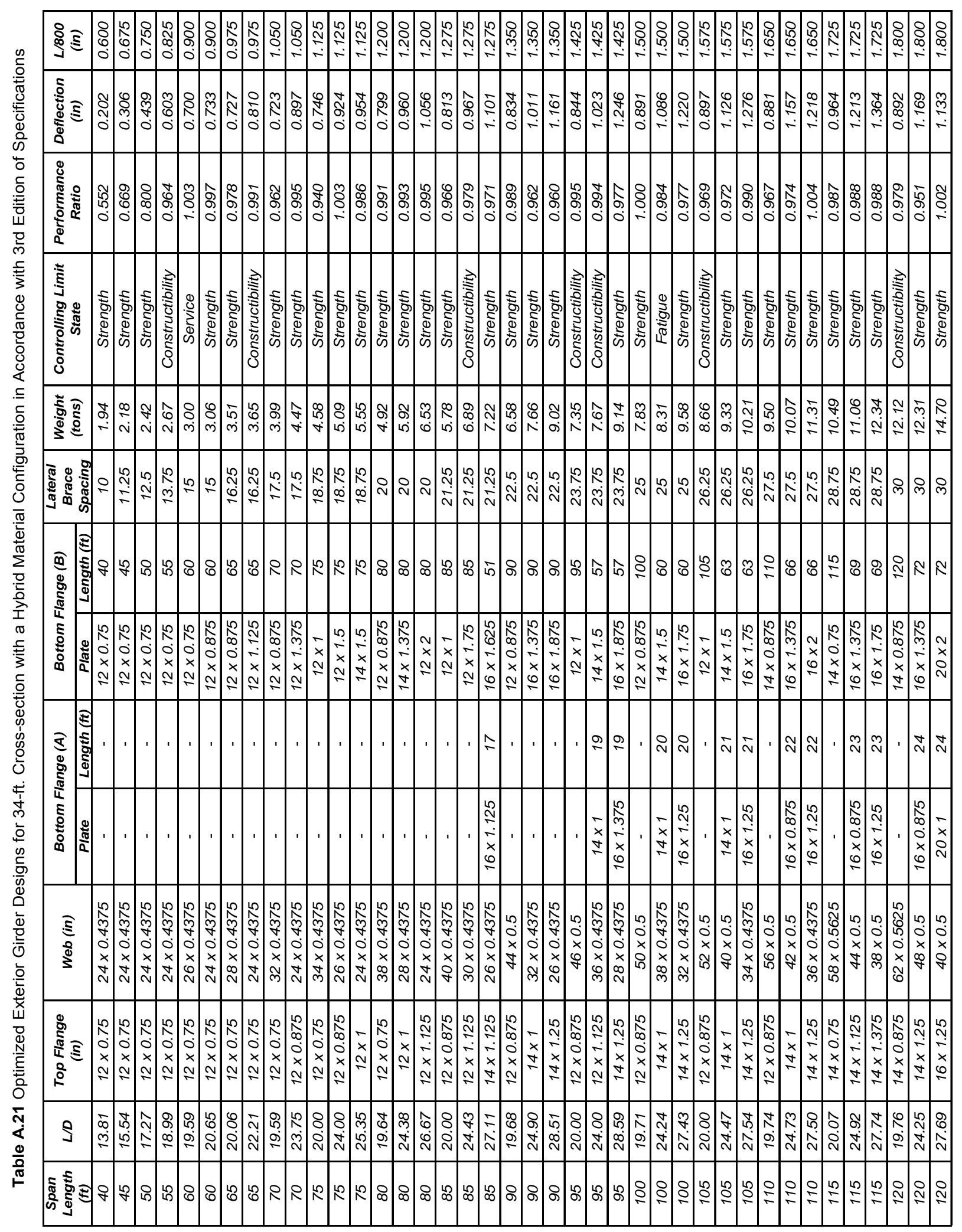




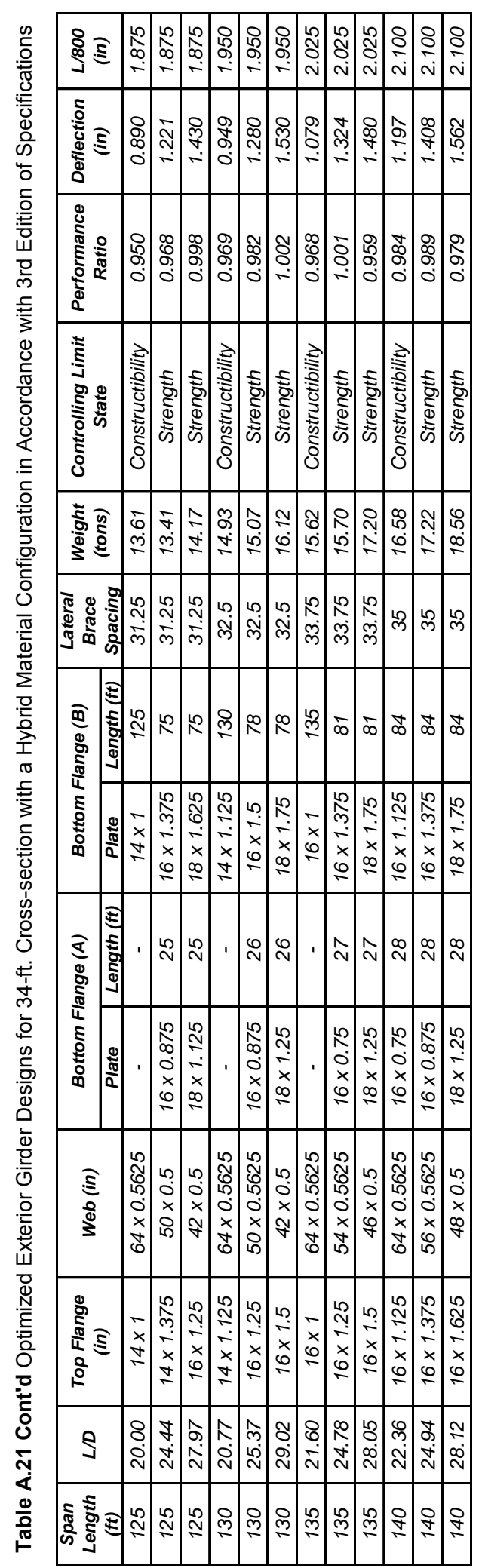




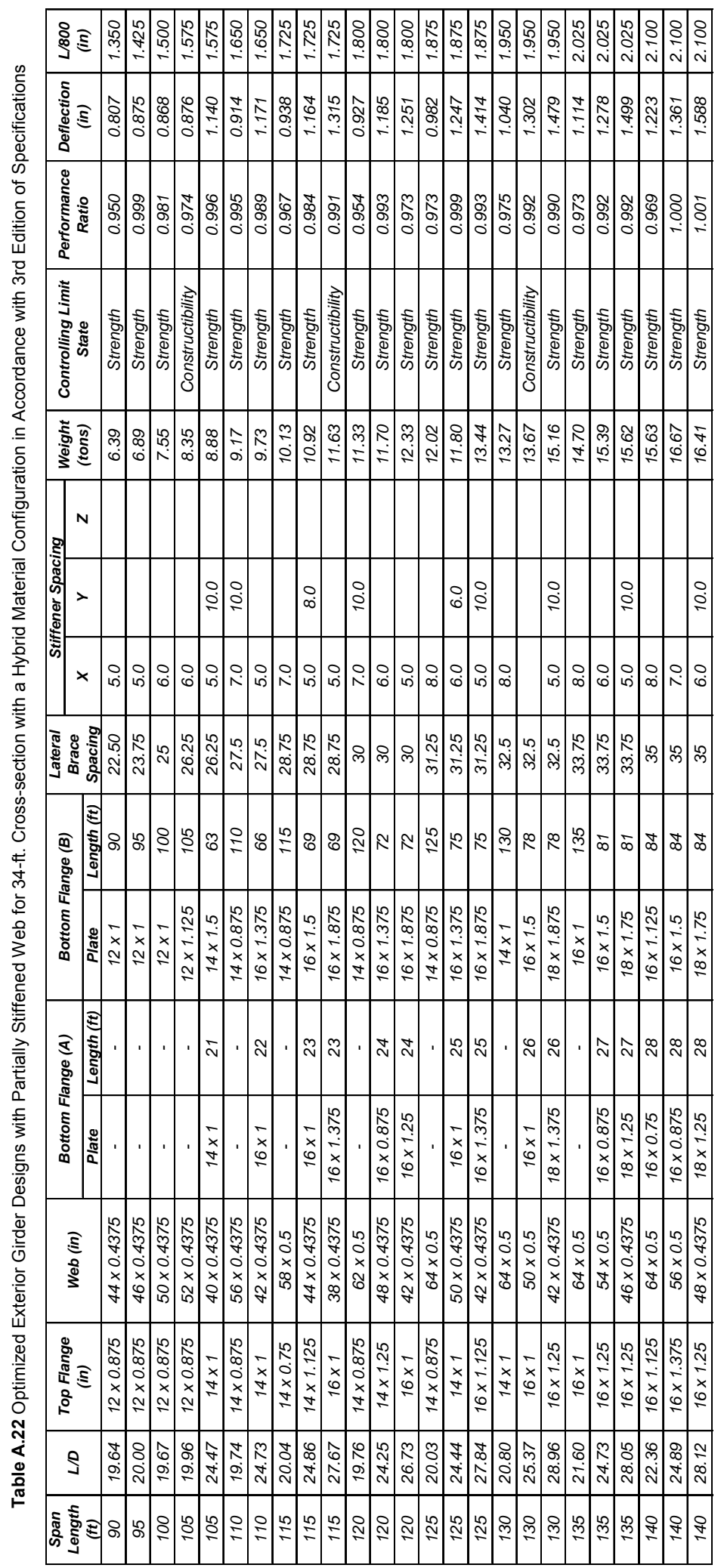




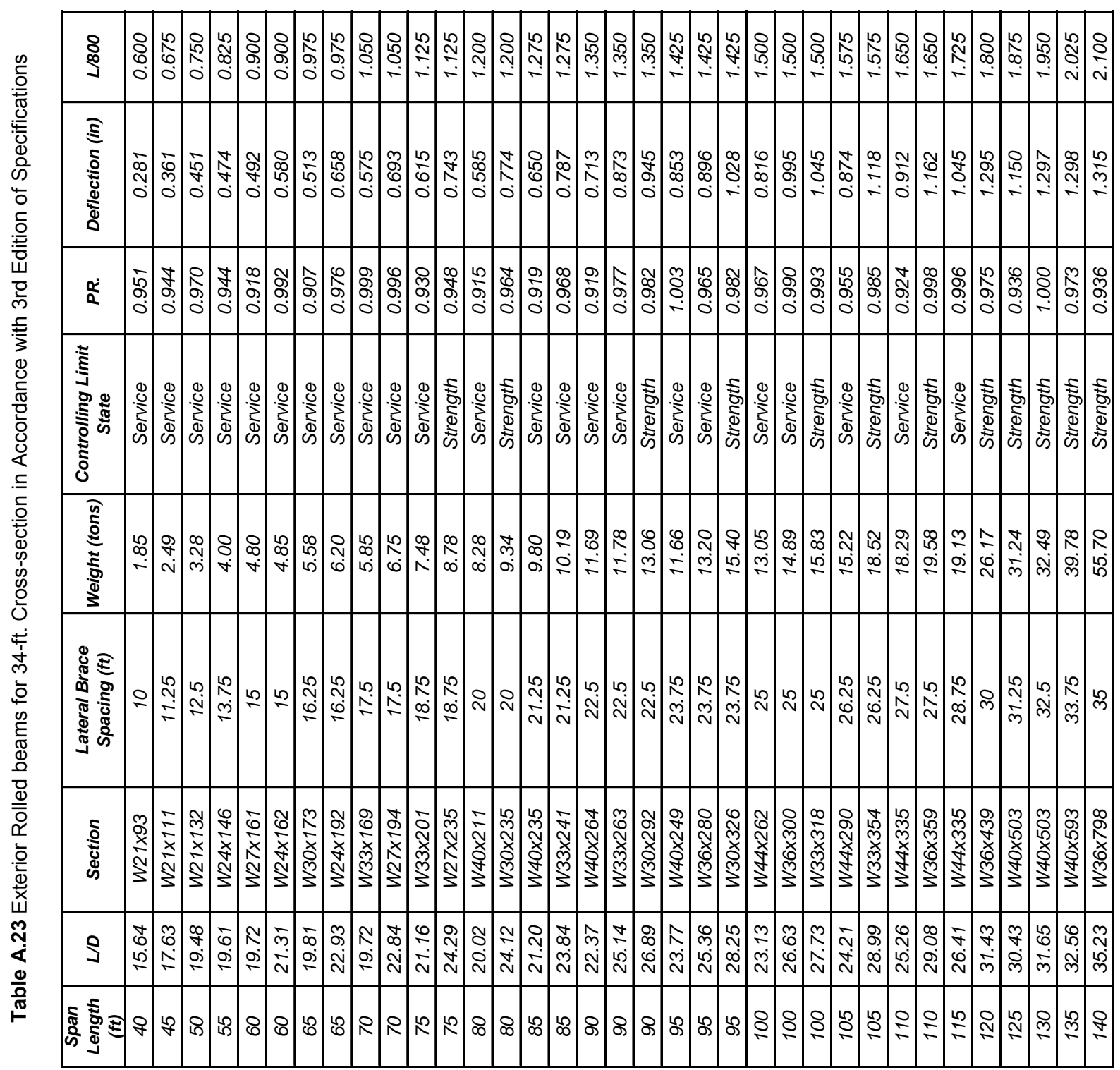


Table A.24 Limited interior Plate Size Designs for 28-ft. Homogeneous Cross Section in Accordance to the 3rd Edition of Specifications

\begin{tabular}{|c|c|c|c|c|c|c|c|c|c|c|}
\hline $\begin{array}{c}\text { Span } \\
\text { Length } \\
\text { (ft) }\end{array}$ & $L / D$ & $\begin{array}{l}\text { Top Flange } \\
\text { (in) }\end{array}$ & Web (in) & $\begin{array}{c}\text { Bottom Flange } \\
\text { (in) }\end{array}$ & $\begin{array}{c}\text { Lateral } \\
\text { Brace } \\
\text { Spacing }\end{array}$ & $\begin{array}{l}\text { Weight } \\
\text { (tons) }\end{array}$ & $\begin{array}{l}\text { Controlling Limit } \\
\text { State }\end{array}$ & $\begin{array}{l}\text { Performance } \\
\quad \text { Ratio }\end{array}$ & $\begin{array}{l}\text { Deflection } \\
\quad \text { (in) }\end{array}$ & $\begin{array}{l}\text { L/800 } \\
\text { (in) }\end{array}$ \\
\hline 40 & 13.81 & $12 \times 0.75$ & $24 \times 0.5$ & $12 \times 0.75$ & 10 & 2.04 & Service & 0.638 & 0.191 & 0.600 \\
\hline 45 & 15.54 & $12 \times 0.75$ & $24 \times 0.5$ & $12 \times 0.75$ & 11.25 & 2.30 & Service & 0.765 & 0.290 & 0.675 \\
\hline 50 & 17.27 & $12 \times 0.75$ & $24 \times 0.5$ & $12 \times 0.75$ & 12.5 & 2.55 & Service & 0.905 & 0.416 & 0.750 \\
\hline 55 & 18.86 & $12 \times 0.75$ & $24 \times 0.5$ & $12 \times 1$ & 13.75 & 3.09 & Service & 0.882 & 0.482 & 0.825 \\
\hline 60 & 20.57 & $12 \times 0.75$ & $24 \times 0.5$ & $14 \times 1$ & 15 & 3.57 & Service & 0.912 & 0.585 & 0.900 \\
\hline 65 & 21.97 & $12 \times 0.75$ & $24 \times 0.4375$ & $12 \times 1.5$ & 16.25 & 4.15 & Service & 0.887 & 0.651 & 0.975 \\
\hline 70 & 19.53 & $12 \times 0.75$ & $32 \times 0.5$ & $12 \times 1$ & 17.5 & 4.41 & Service & 0.980 & 0.634 & 1.050 \\
\hline 70 & 23.66 & $12 \times 0.75$ & $24 \times 0.5$ & $12 \times 1.5$ & 17.5 & 4.64 & Service & 0.984 & 0.810 & 1.050 \\
\hline 75 & 20.93 & $12 \times 0.75$ & $32 \times 0.5$ & $14 \times 1$ & 18.75 & 4.98 & Service & 0.989 & 0.724 & 1.125 \\
\hline 75 & 25.35 & $12 \times 0.75$ & $24 \times 0.5$ & $14 \times 1.5$ & 18.75 & 5.36 & Service & 0.980 & 0.916 & 1.125 \\
\hline 80 & 18.82 & $12 \times 0.75$ & $40 \times 0.5$ & $12 \times 1$ & 20 & 5.58 & Service & 0.961 & 0.635 & 1.200 \\
\hline 80 & 22.07 & $12 \times 0.75$ & $32 \times 0.5$ & $12 \times 1.5$ & 20 & 5.85 & Service & 0.932 & 0.757 & 1.200 \\
\hline 85 & 20.00 & $12 \times 1$ & $40 \times 0.5$ & $14 \times 1$ & 21.25 & 6.65 & Service & 0.951 & 0.706 & 1.275 \\
\hline 85 & 23.45 & $12 \times 0.75$ & $32 \times 0.5$ & $14 \times 1.5$ & 21.25 & 6.65 & Service & 0.920 & 0.833 & 1.275 \\
\hline 90 & 20.97 & $12 \times 0.75$ & $40 \times 0.5$ & $12 \times 1.5$ & 22.5 & 7.20 & Service & 0.904 & 0.729 & 1.350 \\
\hline 90 & 24.83 & $12 \times 1$ & $32 \times 0.5$ & $14 \times 1.5$ & 22.5 & 7.50 & Service & 0.994 & 0.996 & 1.350 \\
\hline 95 & 19.32 & $12 \times 0.75$ & $48 \times 0.5$ & $14 \times 1$ & 23.75 & 7.60 & Service & 0.948 & 0.700 & 1.425 \\
\hline 95 & 22.14 & $12 \times 0.75$ & $40 \times 0.5$ & $12 \times 1.5$ & 23.75 & 7.60 & Service & 0.985 & 0.862 & 1.425 \\
\hline 100 & 20.17 & $12 \times 0.75$ & $48 \times 0.5$ & $12 \times 1.5$ & 25 & 8.68 & Service & 0.888 & 0.713 & 1.500 \\
\hline 100 & 23.30 & $12 \times 0.75$ & $40 \times 0.5$ & $14 \times 1.5$ & 25 & 8.51 & Service & 0.962 & 0.923 & 1.500 \\
\hline 105 & 21.18 & $12 \times 0.75$ & $48 \times 0.5$ & $12 \times 1.5$ & 26.25 & 9.11 & Service & 0.960 & 0.829 & 1.575 \\
\hline 105 & 24.35 & $14 \times 0.75$ & $40 \times 0.5$ & $14 \times 1.75$ & 26.25 & 9.83 & Service & 0.932 & 0.974 & 1.575 \\
\hline 110 & 22.18 & $12 \times 0.75$ & $48 \times 0.5$ & $14 \times 1.5$ & 27.5 & 10.11 & Service & 0.935 & 0.878 & 1.650 \\
\hline 110 & 25.51 & $12 \times 1$ & $40 \times 0.5$ & $14 \times 1.75$ & 27.5 & 10.57 & Service & 0.996 & 1.123 & 1.650 \\
\hline 115 & 23.19 & $12 \times 1$ & $48 \times 0.5$ & $14 \times 1.5$ & 28.75 & 11.15 & Service & 0.990 & 1.004 & 1.725 \\
\hline 115 & 26.67 & $14 \times 1$ & $40 \times 0.5$ & $16 \times 1.75$ & 28.75 & 12.13 & Service & 0.967 & 1.185 & 1.725 \\
\hline 120 & 24.10 & $12 \times 1$ & $48 \times 0.5$ & $14 \times 1.75$ & 30 & 12.35 & Service & 0.959 & 1.044 & 1.800 \\
\hline 120 & 27.69 & $16 \times 1$ & $40 \times 0.5$ & $16 \times 2$ & 30 & 13.88 & Service & 0.939 & 1.237 & 1.800 \\
\hline 125 & 25.10 & $14 \times 1$ & $48 \times 0.5$ & $16 \times 1.75$ & 31.25 & 14.04 & Service & 0.928 & 1.092 & 1.875 \\
\hline 130 & 26.00 & $14 \times 1$ & $48 \times 0.5$ & $14 \times 2$ & 32.5 & 14.60 & Service & 0.993 & 1.226 & 1.950 \\
\hline 135 & 27.00 & $16 \times 1$ & $48 \times 0.5$ & $16 \times 2$ & 33.75 & 16.54 & Service & 0.956 & 1.295 & 2.025 \\
\hline 140 & 28.00 & $16 \times 1.5$ & $48 \times 0.5$ & $16 \times 2$ & 35 & 19.06 & Service & 0.997 & 1.470 & 2.100 \\
\hline
\end{tabular}


Table A.25 Limited Interior Plate Size Designs for 28-ft. Hybrid Cross Section in Accordance to the 3rd Edition of Specifications

\begin{tabular}{|c|c|c|c|c|c|c|c|c|c|c|}
\hline $\begin{array}{l}\text { Span } \\
\text { Length } \\
\text { (ft) }\end{array}$ & $L / D$ & $\begin{array}{l}\text { Top Flange } \\
\text { (in) }\end{array}$ & Web (in) & $\begin{array}{l}\text { Bottom Flange } \\
\text { (in) }\end{array}$ & $\begin{array}{l}\text { Lateral } \\
\text { Brace } \\
\text { Spacing }\end{array}$ & $\begin{array}{l}\text { Weight } \\
\text { (tons) }\end{array}$ & $\begin{array}{l}\text { Controlling Limit } \\
\text { State }\end{array}$ & $\begin{array}{l}\text { Performance } \\
\text { Ratio }\end{array}$ & $\begin{array}{l}\text { Deflection } \\
\text { (in) }\end{array}$ & $\begin{array}{l}L / 800 \\
\text { (in) }\end{array}$ \\
\hline 40 & 13.81 & $12 \times 0.75$ & $24 \times 0.5$ & $12 \times 0.75$ & 10 & 2.04 & Fatigue & 0.537 & 0.191 & 0.600 \\
\hline 45 & 15.54 & $12 \times 0.75$ & $24 \times 0.5$ & $12 \times 0.75$ & 11.25 & 2.30 & Service & 0.547 & 0.290 & 0.675 \\
\hline 50 & 17.27 & $12 \times 0.75$ & $24 \times 0.5$ & $12 \times 0.75$ & 12.5 & 2.55 & Service & 0.647 & 0.416 & 0.750 \\
\hline 55 & 18.99 & $12 \times 0.75$ & $24 \times 0.5$ & $12 \times 0.75$ & 13.75 & 2.81 & Service & 0.753 & 0.571 & 0.825 \\
\hline 60 & 20.72 & $12 \times 0.75$ & $24 \times 0.5$ & $12 \times 0.75$ & 15 & 3.06 & Service & 0.864 & 0.761 & 0.900 \\
\hline 65 & 22.45 & $12 \times 0.75$ & $24 \times 0.5$ & $12 \times 0.75$ & 16.25 & 3.32 & Service & 0.981 & 0.986 & 0.975 \\
\hline 70 & 19.65 & $12 \times 0.75$ & $32 \times 0.5$ & $12 \times 0.75$ & 17.5 & 4.05 & Service & 0.828 & 0.742 & 1.050 \\
\hline 70 & 24.00 & $12 \times 0.75$ & $24 \times 0.5$ & $12 \times 1$ & 17.5 & 3.93 & Service & 0.923 & 1.053 & 1.050 \\
\hline 75 & 21.05 & $12 \times 0.75$ & $32 \times 0.5$ & $12 \times 0.75$ & 18.75 & 4.34 & Service & 0.922 & 0.926 & 1.125 \\
\hline 75 & 25.71 & $12 \times 0.75$ & $24 \times 0.5$ & $14 \times 1$ & 18.75 & 4.47 & Constructibility & 0.984 & 1.197 & 1.125 \\
\hline 80 & 22.33 & $12 \times 0.75$ & $32 \times 0.5$ & $12 \times 1$ & 20 & 5.04 & Service & 0.864 & 0.969 & 1.200 \\
\hline 80 & 27.04 & $14 \times 0.75$ & $24 \times 0.5$ & $14 \times 1.5$ & 20 & 5.92 & Constructibility & 0.989 & 1.122 & 1.200 \\
\hline 85 & 20.10 & $12 \times 0.75$ & $40 \times 0.5$ & $12 \times 0.75$ & 21.25 & 5.50 & Service & 0.884 & 0.889 & 1.275 \\
\hline 90 & 21.28 & $12 \times 0.75$ & $40 \times 0.5$ & $12 \times 0.75$ & 22.5 & 5.82 & Service & 0.968 & 1.064 & 1.350 \\
\hline 90 & 25.12 & $14 \times 0.75$ & $32 \times 0.5$ & $14 \times 1$ & 22.5 & 6.20 & Service & 0.937 & 1.284 & 1.350 \\
\hline 95 & 19.40 & $12 \times 0.75$ & $48 \times 0.5$ & $12 \times 0.75$ & 23.75 & 6.79 & Service & 0.857 & 0.867 & 1.425 \\
\hline 95 & 22.46 & $12 \times 0.75$ & $40 \times 0.5$ & $14 \times 0.75$ & 23.75 & 6.38 & Service & 0.969 & 1.168 & 1.425 \\
\hline 100 & 20.43 & $12 \times 0.75$ & $48 \times 0.5$ & $12 \times 0.75$ & 25 & 7.15 & Service & 0.930 & 1.017 & 1.500 \\
\hline 100 & 23.53 & $12 \times 0.75$ & $40 \times 0.5$ & $12 \times 1$ & 25 & 6.98 & Service & 0.978 & 1.274 & 1.500 \\
\hline 105 & 21.45 & $12 \times 0.75$ & $48 \times 0.5$ & $14 \times 0.75$ & 26.25 & 7.77 & Service & 0.930 & 1.102 & 1.575 \\
\hline 105 & 24.71 & $14 \times 0.75$ & $40 \times 0.5$ & $14 \times 1$ & 26.25 & 7.95 & Constructibility & 0.971 & 1.363 & 1.575 \\
\hline 110 & 22.47 & $12 \times 0.75$ & $48 \times 0.5$ & $14 \times 0.75$ & 27.5 & 8.14 & Service & 1.002 & 1.272 & 1.650 \\
\hline 110 & 25.63 & $12 \times 1$ & $40 \times 0.5$ & $14 \times 1.5$ & 27.5 & 9.92 & Constructibility & 0.946 & 1.237 & 1.650 \\
\hline 115 & 23.39 & $14 \times 0.75$ & $48 \times 0.5$ & $14 \times 1$ & 28.75 & 9.49 & Constructibility & 0.937 & 1.262 & 1.725 \\
\hline 115 & 26.80 & $14 \times 1$ & $40 \times 0.5$ & $14 \times 1.5$ & 28.75 & 10.76 & Constructibility & 0.938 & 1.416 & 1.725 \\
\hline 120 & 24.41 & $14 \times 1$ & $48 \times 0.5$ & $14 \times 1$ & 30 & 10.62 & Strength & 0.976 & 1.435 & 1.800 \\
\hline 120 & 27.96 & $14 \times 1.5$ & $40 \times 0.5$ & $14 \times 1.5$ & 30 & 12.66 & Strength & 0.956 & 1.606 & 1.800 \\
\hline 125 & 25.21 & $12 \times 1$ & $48 \times 0.5$ & $14 \times 1.5$ & 31.25 & 12.12 & Constructibility & 0.985 & 1.297 & 1.875 \\
\hline 130 & 26.22 & $14 \times 1$ & $48 \times 0.5$ & $14 \times 1.5$ & 32.5 & 13.05 & Constructibility & 0.972 & 1.460 & 1.950 \\
\hline 135 & 27.23 & $14 \times 1.5$ & $48 \times 0.5$ & $14 \times 1.5$ & 33.75 & 15.16 & Strength & 0.949 & 1.661 & 2.025 \\
\hline 140 & 28.24 & $14 \times 1.5$ & $48 \times 0.5$ & $16 \times 1.5$ & 35 & 16.44 & Strength & 0.962 & 1.763 & 2.100 \\
\hline
\end{tabular}


Table A.26 Limited Interior Plate Size Designs for 34-ft. Homogeneous Cross Section in Accordance to the 3rd Edition of Specifications

\begin{tabular}{|c|c|c|c|c|c|c|c|c|c|c|}
\hline $\begin{array}{c}\text { Span } \\
\text { Length } \\
(\mathrm{ft})\end{array}$ & $L / D$ & $\begin{array}{l}\text { Top Flange } \\
\text { (in) }\end{array}$ & Web (in) & $\begin{array}{l}\text { Bottom } \\
\text { Flange (in) }\end{array}$ & $\begin{array}{c}\text { Lateral } \\
\text { Brace } \\
\text { Spacing }\end{array}$ & $\begin{array}{l}\text { Weight } \\
\text { (tons) }\end{array}$ & $\begin{array}{c}\text { Controlling Limit } \\
\text { State }\end{array}$ & $\begin{array}{l}\text { Performance } \\
\text { Ratio }\end{array}$ & $\begin{array}{l}\text { Deflection } \\
\text { (in) }\end{array}$ & $\begin{array}{l}L / 800 \\
\text { (in) }\end{array}$ \\
\hline 40 & 13.81 & $12 \times 0.75$ & $24 \times 0.5$ & $12 \times 0.75$ & 10 & 2.04 & Service & 0.740 & 0.191 & 0.600 \\
\hline 45 & 15.54 & $12 \times 0.75$ & $24 \times 0.5$ & $12 \times 0.75$ & 11.25 & 2.30 & Service & 0.887 & 0.290 & 0.675 \\
\hline 50 & 17.27 & $12 \times 0.75$ & $24 \times 0.5$ & $14 \times 0.75$ & 12.5 & 2.68 & Service & 0.954 & 0.381 & 0.750 \\
\hline 55 & 18.86 & $12 \times 0.75$ & $24 \times 0.5$ & $14 \times 1$ & 13.75 & 3.28 & Service & 0.922 & 0.439 & 0.825 \\
\hline 60 & 20.28 & $12 \times 0.75$ & $24 \times 0.5$ & $12 \times 1.5$ & 15 & 3.98 & Service & 0.895 & 0.494 & 0.900 \\
\hline 65 & 21.97 & $12 \times 0.75$ & $24 \times 0.5$ & $14 \times 1.5$ & 16.25 & 4.64 & Service & 0.906 & 0.580 & 0.975 \\
\hline 70 & 19.31 & $12 \times 0.75$ & $32 \times 0.5$ & $12 \times 1.5$ & 17.5 & 5.12 & Service & 0.876 & 0.495 & 1.050 \\
\hline 70 & 23.50 & $12 \times 1$ & $24 \times 0.5$ & $14 \times 1.75$ & 17.5 & 5.78 & Service & 0.899 & 0.660 & 1.050 \\
\hline 75 & 20.69 & $12 \times 0.75$ & $32 \times 0.5$ & $12 \times 1.5$ & 18.75 & 5.49 & Service & 0.976 & 0.618 & 1.125 \\
\hline 75 & 25.17 & $12 \times 1$ & $24 \times 0.5$ & $14 \times 1.75$ & 18.75 & 6.19 & Service & 1.003 & 0.823 & 1.125 \\
\hline 80 & 22.07 & $12 \times 0.75$ & $32 \times 0.5$ & $14 \times 1.5$ & 20 & 6.26 & Service & 0.968 & 0.689 & 1.200 \\
\hline 80 & 26.67 & $14 \times 1$ & $24 \times 0.5$ & $14 \times 2$ & 20 & 7.35 & Strength & 1.003 & 0.915 & 1.200 \\
\hline 85 & 19.81 & $12 \times 0.75$ & $40 \times 0.5$ & $12 \times 1.5$ & 21.25 & 6.80 & Service & 0.956 & 0.609 & 1.275 \\
\hline 85 & 23.31 & $12 \times 1$ & $32 \times 0.5$ & $14 \times 1.75$ & 21.25 & 7.59 & Service & 0.944 & 0.752 & 1.275 \\
\hline 90 & 18.15 & $12 \times 0.75$ & $48 \times 0.5$ & $12 \times 1.5$ & 22.5 & 7.81 & Service & 0.869 & 0.514 & 1.350 \\
\hline 90 & 24.62 & $12 \times 1$ & $32 \times 0.5$ & $14 \times 1.875$ & 22.5 & 8.31 & Service & 0.984 & 0.859 & 1.350 \\
\hline 95 & 19.16 & $12 \times 0.75$ & $48 \times 0.5$ & $12 \times 1.5$ & 23.75 & 8.24 & Service & 0.947 & 0.608 & 1.425 \\
\hline 95 & 22.03 & $14 \times 1$ & $40 \times 0.5$ & $14 \times 1.75$ & 23.75 & 9.46 & Service & 0.906 & 0.711 & 1.425 \\
\hline 100 & 20.17 & $12 \times 0.75$ & $48 \times 0.5$ & $14 \times 1.5$ & 25 & 9.19 & Service & 0.929 & 0.655 & 1.500 \\
\hline 100 & 23.19 & $12 \times 1$ & $40 \times 0.5$ & $14 \times 1.75$ & 25 & 9.61 & Service & 0.989 & 0.837 & 1.500 \\
\hline 105 & 21.18 & $12 \times 1$ & $48 \times 0.5$ & $14 \times 1.5$ & 26.25 & 10.18 & Service & 0.989 & 0.759 & 1.575 \\
\hline 105 & 24.23 & $14 \times 1$ & $40 \times 0.5$ & $14 \times 2$ & 26.25 & 11.08 & Service & 0.968 & 0.889 & 1.575 \\
\hline 110 & 22.18 & $14 \times 0.75$ & $48 \times 0.5$ & $16 \times 1.5$ & 27.5 & 10.95 & Service & 0.981 & 0.811 & 1.650 \\
\hline 110 & 25.38 & $14 \times 1$ & $40 \times 0.5$ & $16 \times 2$ & 27.5 & 12.35 & Constructibility & 0.989 & 0.946 & 1.650 \\
\hline 115 & 23.10 & $14 \times 1$ & $48 \times 0.5$ & $16 \times 1.75$ & 28.75 & 12.91 & Strength & 0.978 & 0.843 & 1.725 \\
\hline 115 & 26.54 & $14 \times 1.5$ & $40 \times 0.5$ & $16 \times 2$ & 28.75 & 14.28 & Service & 0.998 & 1.076 & 1.725 \\
\hline 120 & 24.10 & $14 \times 1$ & $48 \times 0.5$ & $16 \times 1.75$ & 30 & 13.48 & Strength & 1.004 & 0.961 & 1.800 \\
\hline 120 & 27.69 & $16 \times 1.5$ & $40 \times 0.5$ & $18 \times 2$ & 30 & 16.33 & Strength & 0.994 & 1.134 & 1.800 \\
\hline 125 & 25.00 & $16 \times 1$ & $48 \times 0.5625$ & $16 \times 2$ & 31.25 & 15.95 & Service & 0.961 & 0.983 & 1.875 \\
\hline 130 & 26.00 & $16 \times 1.5$ & $48 \times 0.5625$ & $18 \times 2$ & 32.5 & 19.24 & Service & 0.924 & 1.023 & 1.950 \\
\hline 135 & 27.00 & $16 \times 1.5$ & $48 \times 0.5625$ & $18 \times 2$ & 33.75 & 19.98 & Service & 0.983 & 1.172 & 2.025 \\
\hline 140 & 28.00 & $16 \times 1.5$ & $48 \times 0.5625$ & $20 \times 2$ & 35 & 21.68 & Service & 0.967 & 1.263 & 2.100 \\
\hline
\end{tabular}


Table A.27 Limited Interior Plate Size Designs for 34-ft. Hybrid Cross Section in Accordance to the 3rd Edition of Specifications

\begin{tabular}{|c|c|c|c|c|c|c|c|c|c|c|}
\hline $\begin{array}{l}\text { Span } \\
\text { Length } \\
\text { (ft) }\end{array}$ & $L / D$ & $\begin{array}{l}\text { Top Flange } \\
\text { (in) }\end{array}$ & Web (in) & $\begin{array}{l}\text { Bottom } \\
\text { Flange (in) }\end{array}$ & $\begin{array}{c}\text { Lateral } \\
\text { Brace } \\
\text { Spacing }\end{array}$ & $\begin{array}{l}\text { Weight } \\
\text { (tons) }\end{array}$ & $\begin{array}{c}\text { Controlling Limit } \\
\text { State }\end{array}$ & $\begin{array}{l}\text { Performance } \\
\text { Ratio }\end{array}$ & $\begin{array}{l}\text { Deflection } \\
\quad \text { (in) }\end{array}$ & $\begin{array}{l}L / 800 \\
\text { (in) }\end{array}$ \\
\hline 40 & 13.81 & $12 \times 0.75$ & $24 \times 0.5$ & $12 \times 0.75$ & 10 & 2.04 & Fatigue & 0.537 & 0.191 & 0.600 \\
\hline 45 & 15.54 & $12 \times 0.75$ & $24 \times 0.5$ & $12 \times 0.75$ & 11.25 & 2.30 & Service & 0.634 & 0.290 & 0.675 \\
\hline 50 & 17.27 & $12 \times 0.75$ & $24 \times 0.5$ & $12 \times 0.75$ & 12.5 & 2.55 & Service & 0.751 & 0.416 & 0.750 \\
\hline 55 & 18.99 & $12 \times 0.75$ & $24 \times 0.5$ & $12 \times 0.75$ & 13.75 & 2.81 & Service & 0.874 & 0.571 & 0.825 \\
\hline 60 & 20.72 & $12 \times 0.75$ & $24 \times 0.5$ & $12 \times 0.75$ & 15 & 3.06 & Service & 1.003 & 0.761 & 0.900 \\
\hline 65 & 22.29 & $12 \times 0.75$ & $24 \times 0.5$ & $12 \times 1$ & 16.25 & 3.65 & Service & 0.952 & 0.832 & 0.975 \\
\hline 70 & 19.65 & $12 \times 0.75$ & $32 \times 0.5$ & $12 \times 0.75$ & 17.5 & 4.05 & Service & 0.960 & 0.742 & 1.050 \\
\hline 70 & 24.00 & $14 \times 0.75$ & $24 \times 0.5$ & $14 \times 1$ & 17.5 & 4.35 & Service & 0.958 & 0.958 & 1.050 \\
\hline 75 & 21.05 & $12 \times 0.75$ & $32 \times 0.5$ & $14 \times 0.75$ & 18.75 & 4.53 & Service & 0.977 & 0.854 & 1.125 \\
\hline 75 & 25.35 & $12 \times 1$ & $24 \times 0.5$ & $12 \times 1.5$ & 18.75 & 5.36 & Constructibility & 0.936 & 1.010 & 1.125 \\
\hline 80 & 22.33 & $12 \times 0.75$ & $32 \times 0.5$ & $14 \times 1$ & 20 & 5.31 & Constructibility & 0.948 & 0.888 & 1.200 \\
\hline 80 & 27.04 & $14 \times 1$ & $24 \times 0.5$ & $14 \times 1.5$ & 20 & 6.40 & Strength & 0.964 & 1.119 & 1.200 \\
\hline 85 & 20.10 & $12 \times 0.75$ & $40 \times 0.5$ & $14 \times 0.75$ & 21.25 & 5.71 & Service & 0.942 & 0.825 & 1.275 \\
\hline 85 & 23.72 & $12 \times 1$ & $32 \times 0.5$ & $14 \times 1$ & 21.25 & 6.07 & Strength & 0.991 & 1.073 & 1.275 \\
\hline 90 & 21.18 & $12 \times 0.75$ & $40 \times 0.5$ & $12 \times 1$ & 22.5 & 6.28 & Service & 0.958 & 0.919 & 1.350 \\
\hline 90 & 24.83 & $12 \times 1$ & $32 \times 0.5$ & $12 \times 1.5$ & 22.5 & 7.04 & Constructibility & 0.974 & 1.095 & 1.350 \\
\hline 95 & 19.40 & $12 \times 0.75$ & $48 \times 0.5$ & $12 \times 0.75$ & 23.75 & 6.79 & Service & 0.994 & 0.867 & 1.425 \\
\hline 95 & 22.35 & $12 \times 1$ & $40 \times 0.5$ & $14 \times 1$ & 23.75 & 7.44 & Strength & 0.943 & 1.000 & 1.425 \\
\hline 100 & 20.43 & $12 \times 0.75$ & $48 \times 0.5$ & $14 \times 0.75$ & 25 & 7.40 & Service & 0.996 & 0.948 & 1.500 \\
\hline 100 & 23.30 & $12 \times 1$ & $40 \times 0.5$ & $14 \times 1.5$ & 25 & 9.02 & Constructibility & 0.920 & 0.922 & 1.500 \\
\hline 105 & 21.36 & $12 \times 0.75$ & $48 \times 0.5$ & $14 \times 1$ & 26.25 & 8.40 & Constructibility & 0.993 & 0.954 & 1.575 \\
\hline 105 & 24.47 & $12 \times 1.5$ & $40 \times 0.5$ & $12 \times 1.5$ & 26.25 & 10.00 & Strength & 0.975 & 1.169 & 1.575 \\
\hline 110 & 22.37 & $12 \times 1$ & $48 \times 0.5$ & $14 \times 1$ & 27.5 & 9.36 & Strength & 0.984 & 1.100 & 1.650 \\
\hline 110 & 25.63 & $14 \times 1.5$ & $40 \times 0.5$ & $14 \times 1.5$ & 27.5 & 11.60 & Strength & 0.961 & 1.227 & 1.650 \\
\hline 115 & 23.19 & $14 \times 1$ & $48 \times 0.5$ & $14 \times 1.5$ & 28.75 & 11.54 & Strength & 0.973 & 1.000 & 1.725 \\
\hline 115 & 26.80 & $14 \times 1.5$ & $40 \times 0.5$ & $16 \times 1.5$ & 28.75 & 12.72 & Strength & 0.953 & 1.297 & 1.725 \\
\hline 120 & 24.20 & $14 \times 1$ & $48 \times 0.5$ & $14 \times 1.5$ & 30 & 12.05 & Strength & 0.998 & 1.140 & 1.800 \\
\hline 120 & 27.83 & $14 \times 1.5$ & $40 \times 0.5$ & $14 \times 1.75$ & 30 & 13.37 & Strength & 1.003 & 1.453 & 1.800 \\
\hline 125 & 25.21 & $12 \times 1.5$ & $48 \times 0.5625$ & $14 \times 1.5$ & 31.25 & 14.04 & Strength & 0.944 & 1.261 & 1.875 \\
\hline 130 & 26.22 & $12 \times 1.5$ & $48 \times 0.5625$ & $14 \times 1.5$ & 32.5 & 14.60 & Strength & 1.004 & 1.422 & 1.950 \\
\hline 135 & 27.11 & $14 \times 1.5$ & $48 \times 0.5625$ & $14 \times 1.75$ & 33.75 & 16.65 & Strength & 0.976 & 1.481 & 2.025 \\
\hline 140 & 28.12 & $14 \times 1.5$ & $48 \times 0.5625$ & $16 \times 1.75$ & 35 & 18.10 & Constructibility & 0.991 & 1.573 & 2.100 \\
\hline
\end{tabular}


Table A.28 Limited Exterior Plate Size Designs for 28-ft. Homogeneous Cross Section in Accordance to the 3rd Edition of Specifications

\begin{tabular}{|c|c|c|c|c|c|c|c|c|c|c|}
\hline $\begin{array}{c}\text { Span } \\
\text { Length } \\
\text { (ft) }\end{array}$ & $L / D$ & $\begin{array}{l}\text { Top Flange } \\
\text { (in) }\end{array}$ & Web (in) & $\begin{array}{c}\text { Bottom } \\
\text { Flange (in) }\end{array}$ & $\begin{array}{l}\text { Lateral } \\
\text { Brace } \\
\text { Spacing }\end{array}$ & $\begin{array}{l}\text { Weight } \\
\text { (tons) }\end{array}$ & $\begin{array}{c}\text { Controlling Limit } \\
\text { State }\end{array}$ & $\begin{array}{l}\text { Performance } \\
\text { Ratio }\end{array}$ & $\begin{array}{l}\text { Deflection } \\
\text { (in) }\end{array}$ & $\begin{array}{c}\text { L/800 } \\
\text { (in) }\end{array}$ \\
\hline 40 & 13.81 & $12 \times 0.75$ & $24 \times 0.5$ & $12 \times 0.75$ & 10 & 2.04 & Service & 0.629 & 0.198 & 0.600 \\
\hline 45 & 15.54 & $12 \times 0.75$ & $24 \times 0.5$ & $12 \times 0.75$ & 11.25 & 2.30 & Service & 0.767 & 0.300 & 0.675 \\
\hline 50 & 17.27 & $12 \times 0.75$ & $24 \times 0.5$ & $12 \times 0.75$ & 12.5 & 2.55 & Service & 0.921 & 0.430 & 0.750 \\
\hline 55 & 18.86 & $12 \times 0.75$ & $24 \times 0.5$ & $12 \times 1$ & 13.75 & 3.09 & Service & 0.899 & 0.500 & 0.825 \\
\hline 60 & 20.28 & $12 \times 0.75$ & $24 \times 0.5$ & $12 \times 1.5$ & 15 & 3.98 & Constructibility & 0.944 & 0.514 & 0.900 \\
\hline 65 & 21.97 & $12 \times 1$ & $24 \times 0.5$ & $12 \times 1.5$ & 16.25 & 4.64 & Service & 0.886 & 0.665 & 0.975 \\
\hline 70 & 19.53 & $12 \times 1$ & $32 \times 0.5$ & $12 \times 1$ & 17.5 & 4.76 & Service & 0.991 & 0.656 & 1.050 \\
\hline 70 & 23.66 & $12 \times 0.75$ & $24 \times 0.5$ & $14 \times 1.5$ & 17.5 & 5.00 & Constructibility & 0.927 & 0.765 & 1.050 \\
\hline 75 & 20.69 & $12 \times 0.75$ & $32 \times 0.5$ & $12 \times 1.5$ & 18.75 & 5.49 & Service & 0.856 & 0.643 & 1.125 \\
\hline 75 & 25.17 & $14 \times 0.75$ & $24 \times 0.5$ & $14 \times 1.75$ & 18.75 & 6.00 & Strength & 0.938 & 0.860 & 1.125 \\
\hline 80 & 22.07 & $12 \times 1$ & $32 \times 0.5$ & $12 \times 1.5$ & 20 & 6.26 & Service & 0.943 & 0.786 & 1.200 \\
\hline 80 & 26.67 & $12 \times 1$ & $24 \times 0.5$ & $14 \times 2$ & 20 & 7.08 & Strength & 0.954 & 0.961 & 1.200 \\
\hline 85 & 19.81 & $12 \times 0.75$ & $40 \times 0.5$ & $12 \times 1.5$ & 21.25 & 6.80 & Constructibility & 0.880 & 0.634 & 1.275 \\
\hline 85 & 23.45 & $14 \times 0.75$ & $32 \times 0.5$ & $14 \times 1.5$ & 21.25 & 6.87 & Service & 0.938 & 0.868 & 1.275 \\
\hline 90 & 20.97 & $12 \times 0.75$ & $40 \times 0.5$ & $12 \times 1.5$ & 22.5 & 7.20 & Constructibility & 0.978 & 0.758 & 1.350 \\
\hline 90 & 24.69 & $12 \times 1$ & $32 \times 0.5$ & $14 \times 1.75$ & 22.5 & 8.04 & Constructibility & 0.959 & 0.939 & 1.350 \\
\hline 95 & 19.32 & $12 \times 0.75$ & $48 \times 0.5$ & $14 \times 1$ & 23.75 & 7.60 & Service & 0.960 & 0.727 & 1.425 \\
\hline 95 & 22.14 & $12 \times 1$ & $40 \times 0.5$ & $12 \times 1.5$ & 23.75 & 8.08 & Service & 0.993 & 0.895 & 1.425 \\
\hline 100 & 20.17 & $12 \times 0.75$ & $48 \times 0.5$ & $12 \times 1.5$ & 25 & 8.68 & Constructibility & 0.994 & 0.743 & 1.500 \\
\hline 100 & 23.30 & $12 \times 1$ & $40 \times 0.5$ & $14 \times 1.5$ & 25 & 9.02 & Service & 0.971 & 0.960 & 1.500 \\
\hline 105 & 21.18 & $12 \times 0.75$ & $48 \times 0.5$ & $12 \times 1.5$ & 26.25 & 9.11 & Constructibility & 0.990 & 0.863 & 1.575 \\
\hline 105 & 24.35 & $12 \times 1$ & $40 \times 0.5$ & $14 \times 1.75$ & 26.25 & 10.09 & Constructibility & 0.964 & 1.015 & 1.575 \\
\hline 110 & 22.18 & $14 \times 0.75$ & $48 \times 0.5$ & $14 \times 1.5$ & 27.5 & 10.39 & Service & 0.944 & 0.915 & 1.650 \\
\hline 110 & 25.38 & $14 \times 1$ & $40 \times 0.5$ & $14 \times 2$ & 27.5 & 11.60 & Strength & 0.933 & 1.076 & 1.650 \\
\hline 115 & 23.10 & $14 \times 1$ & $48 \times 0.5$ & $14 \times 1.75$ & 28.75 & 12.23 & Service & 0.905 & 0.954 & 1.725 \\
\hline 115 & 26.54 & $14 \times 1.5$ & $40 \times 0.5$ & $14 \times 2$ & 28.75 & 13.50 & Strength & 1.001 & 1.222 & 1.725 \\
\hline 120 & 24.10 & $14 \times 1$ & $48 \times 0.5$ & $14 \times 1.75$ & 30 & 12.76 & Service & 0.973 & 1.087 & 1.800 \\
\hline 120 & 27.69 & $14 \times 1.5$ & $40 \times 0.5$ & $16 \times 2$ & 30 & 14.90 & Strength & 0.990 & 1.284 & 1.800 \\
\hline 125 & 25.10 & $14 \times 1.5$ & $48 \times 0.5$ & $16 \times 1.75$ & 31.25 & 15.53 & Strength & 0.932 & 1.129 & 1.875 \\
\hline 130 & 26.11 & $14 \times 1.5$ & $48 \times 0.5$ & $16 \times 1.75$ & 32.5 & 16.15 & Service & 0.995 & 1.272 & 1.950 \\
\hline 135 & 27.00 & $14 \times 1.5$ & $48 \times 0.5$ & $16 \times 2$ & 33.75 & 17.69 & Constructibility & 0.998 & 1.343 & 2.025 \\
\hline 140 & 28.00 & $16 \times 1.5$ & $48 \times 0.5$ & $18 \times 2$ & 35 & 20.01 & Strength & 0.967 & 1.430 & 2.100 \\
\hline
\end{tabular}


Table A.29 Limited Exterior Plate Size Designs for 28-ft. Hybrid Cross Section in Accordance to the 3rd Edition of Specifications

\begin{tabular}{|c|c|c|c|c|c|c|c|c|c|c|}
\hline $\begin{array}{c}\text { Span } \\
\text { Length } \\
\text { (ft) }\end{array}$ & $L / D$ & $\begin{array}{l}\text { Top Flange } \\
\text { (in) }\end{array}$ & Web (in) & $\begin{array}{l}\text { Bottom } \\
\text { Flange (in) }\end{array}$ & $\begin{array}{c}\text { Lateral } \\
\text { Brace } \\
\text { Spacing }\end{array}$ & $\begin{array}{l}\text { Weight } \\
\text { (tons) }\end{array}$ & $\begin{array}{c}\text { Controlling Limit } \\
\text { State }\end{array}$ & $\begin{array}{l}\text { Performance } \\
\text { Ratio }\end{array}$ & $\begin{array}{l}\text { Deflection } \\
\text { (in) }\end{array}$ & $\begin{array}{l}L / 800 \\
\text { (in) }\end{array}$ \\
\hline 40 & 13.81 & $12 \times 0.75$ & $24 \times 0.5$ & $12 \times 0.75$ & 10 & 2.04 & Constructibility & 0.462 & 0.198 & 0.600 \\
\hline 45 & 15.54 & $12 \times 0.75$ & $24 \times 0.5$ & $12 \times 0.75$ & 11.25 & 2.30 & Constructibility & 0.569 & 0.300 & 0.675 \\
\hline 50 & 17.27 & $12 \times 0.75$ & $24 \times 0.5$ & $12 \times 0.75$ & 12.5 & 2.55 & Constructibility & 0.687 & 0.430 & 0.750 \\
\hline 55 & 18.99 & $12 \times 0.75$ & $24 \times 0.5$ & $12 \times 0.75$ & 13.75 & 2.81 & Constructibility & 0.817 & 0.591 & 0.825 \\
\hline 60 & 20.72 & $12 \times 0.75$ & $24 \times 0.5$ & $12 \times 0.75$ & 15 & 3.06 & Constructibility & 0.988 & 0.787 & 0.900 \\
\hline 65 & 22.45 & $12 \times 0.75$ & $24 \times 0.5$ & $14 \times 0.75$ & 16.25 & 3.48 & Strength & 0.952 & 0.936 & 0.975 \\
\hline 70 & 19.65 & $12 \times 0.75$ & $32 \times 0.5$ & $12 \times 0.75$ & 17.5 & 4.05 & Strength & 0.859 & 0.767 & 1.050 \\
\hline 70 & 24.00 & $12 \times 0.75$ & $24 \times 0.5$ & $12 \times 1$ & 17.5 & 3.93 & Strength & 1.000 & 1.091 & 1.050 \\
\hline 75 & 21.05 & $12 \times 0.75$ & $32 \times 0.5$ & $12 \times 0.75$ & 18.75 & 4.34 & Strength & 0.961 & 0.957 & 1.125 \\
\hline 75 & 25.35 & $12 \times 1$ & $24 \times 0.5$ & $12 \times 1.5$ & 18.75 & 5.36 & Strength & 0.917 & 1.051 & 1.125 \\
\hline 80 & 22.33 & $12 \times 0.75$ & $32 \times 0.5$ & $12 \times 1$ & 20 & 5.04 & Strength & 0.928 & 1.004 & 1.200 \\
\hline 80 & 27.04 & $14 \times 0.75$ & $24 \times 0.5$ & $14 \times 1.5$ & 20 & 5.92 & Constructibility & 1.002 & 1.170 & 1.200 \\
\hline 85 & 20.10 & $12 \times 0.75$ & $40 \times 0.5$ & $12 \times 0.75$ & 21.25 & 5.50 & Constructibility & 0.932 & 0.920 & 1.275 \\
\hline 85 & 23.72 & $14 \times 0.75$ & $32 \times 0.5$ & $14 \times 1$ & 21.25 & 5.86 & Strength & 0.970 & 1.114 & 1.275 \\
\hline 90 & 21.18 & $12 \times 0.75$ & $40 \times 0.5$ & $12 \times 1$ & 22.5 & 6.28 & Constructibility & 0.988 & 0.952 & 1.350 \\
\hline 90 & 24.83 & $12 \times 1$ & $32 \times 0.5$ & $14 \times 1.5$ & 22.5 & 7.50 & Constructibility & 0.965 & 1.037 & 1.350 \\
\hline 95 & 19.40 & $12 \times 0.75$ & $48 \times 0.5$ & $12 \times 0.75$ & 23.75 & 6.79 & Constructibility & 0.968 & 0.898 & 1.425 \\
\hline 95 & 22.14 & $12 \times 1$ & $40 \times 0.5$ & $12 \times 1.5$ & 23.75 & 8.08 & Constructibility & 0.869 & 0.895 & 1.425 \\
\hline 100 & 20.43 & $12 \times 0.75$ & $48 \times 0.5$ & $12 \times 0.75$ & 25 & 7.15 & Constructibility & 0.977 & 1.052 & 1.500 \\
\hline 100 & 23.53 & $14 \times 0.75$ & $40 \times 0.5$ & $14 \times 1$ & 25 & 7.57 & Strength & 0.981 & 1.217 & 1.500 \\
\hline 105 & 21.45 & $14 \times 0.75$ & $48 \times 0.5$ & $14 \times 0.75$ & 26.25 & 8.04 & Strength & 0.981 & 1.141 & 1.575 \\
\hline 105 & 24.47 & $12 \times 1$ & $40 \times 0.5$ & $14 \times 1.5$ & 26.25 & 9.47 & Constructibility & 0.975 & 1.116 & 1.575 \\
\hline 110 & 22.37 & $12 \times 1$ & $48 \times 0.5$ & $12 \times 1$ & 27.5 & 8.98 & Strength & 0.990 & 1.232 & 1.650 \\
\hline 110 & 25.63 & $14 \times 1$ & $40 \times 0.5$ & $14 \times 1.5$ & 27.5 & 10.29 & Strength & 0.903 & 1.286 & 1.650 \\
\hline 115 & 23.39 & $14 \times 1$ & $48 \times 0.5$ & $14 \times 1$ & 28.75 & 10.17 & Strength & 0.989 & 1.306 & 1.725 \\
\hline 115 & 26.80 & $14 \times 1$ & $40 \times 0.5$ & $14 \times 1.5$ & 28.75 & 10.76 & Strength & 0.972 & 1.474 & 1.725 \\
\hline 120 & 24.20 & $14 \times 1$ & $48 \times 0.5$ & $14 \times 1.5$ & 30 & 12.05 & Constructibility & 0.970 & 1.190 & 1.800 \\
\hline 120 & 27.96 & $14 \times 1.5$ & $40 \times 0.5$ & $16 \times 1.5$ & 30 & 13.27 & Strength & 0.956 & 1.541 & 1.800 \\
\hline 125 & 25.21 & $14 \times 1.5$ & $48 \times 0.5$ & $14 \times 1.5$ & 31.25 & 14.04 & Strength & 0.899 & 1.336 & 1.875 \\
\hline 130 & 26.22 & $14 \times 1.5$ & $48 \times 0.5$ & $14 \times 1.5$ & 32.5 & 14.60 & Strength & 0.960 & 1.507 & 1.950 \\
\hline 135 & 27.23 & $16 \times 1.5$ & $48 \times 0.5$ & $16 \times 1.5$ & 33.75 & 16.54 & Strength & 0.944 & 1.593 & 2.025 \\
\hline 140 & 28.24 & $16 \times 1.5$ & $48 \times 0.5$ & $16 \times 1.5$ & 35 & 17.15 & Strength & 1.003 & 1.827 & 2.100 \\
\hline
\end{tabular}


Table A.30 Limited Exterior Plate Size Designs for 34-ft. Homogeneous Cross Section in Accordance to the 3rd Edition of Specifications

\begin{tabular}{|c|c|c|c|c|c|c|c|c|c|c|}
\hline $\begin{array}{l}\text { Span } \\
\text { Length } \\
\text { (ft) }\end{array}$ & $L / D$ & $\begin{array}{l}\text { Top Flange } \\
\text { (in) }\end{array}$ & Web (in) & $\begin{array}{l}\text { Bottom } \\
\text { Flange (in) }\end{array}$ & $\begin{array}{c}\text { Lateral } \\
\text { Brace } \\
\text { Spacing }\end{array}$ & $\begin{array}{l}\text { Weight } \\
\text { (tons) }\end{array}$ & $\begin{array}{c}\text { Controlling Limit } \\
\text { State }\end{array}$ & $\begin{array}{l}\text { Performance } \\
\text { Ratio }\end{array}$ & $\begin{array}{l}\text { Deflection } \\
\text { (in) }\end{array}$ & $\begin{array}{l}L / 800 \\
\text { (in) }\end{array}$ \\
\hline 40 & 13.81 & $12 \times 0.75$ & $24 \times 0.5$ & $12 \times 0.75$ & 10 & 2.04 & Service & 0.741 & 0.196 & 0.600 \\
\hline 45 & 15.54 & $12 \times 0.75$ & $24 \times 0.5$ & $12 \times 0.75$ & 11.25 & 2.30 & Service & 0.902 & 0.297 & 0.675 \\
\hline 50 & 17.14 & $12 \times 0.75$ & $24 \times 0.5$ & $12 \times 1$ & 12.5 & 2.81 & Service & 0.898 & 0.359 & 0.750 \\
\hline 55 & 18.86 & $12 \times 0.75$ & $24 \times 0.5$ & $14 \times 1$ & 13.75 & 3.28 & Service & 0.947 & 0.450 & 0.825 \\
\hline 60 & 20.28 & $14 \times 0.75$ & $24 \times 0.5$ & $14 \times 1.5$ & 15 & 4.44 & Constructibility & 0.878 & 0.460 & 0.900 \\
\hline 65 & 21.97 & $12 \times 0.75$ & $24 \times 0.5$ & $14 \times 1.5$ & 16.25 & 4.64 & Constructibility & 0.950 & 0.596 & 0.975 \\
\hline 70 & 19.31 & $12 \times 0.75$ & $32 \times 0.5$ & $12 \times 1.5$ & 17.5 & 5.12 & Service & 0.894 & 0.509 & 1.050 \\
\hline 70 & 23.66 & $14 \times 0.75$ & $24 \times 0.5$ & $16 \times 1.5$ & 17.5 & 5.54 & Strength & 0.961 & 0.693 & 1.050 \\
\hline 75 & 20.69 & $12 \times 0.75$ & $32 \times 0.5$ & $12 \times 1.5$ & 18.75 & 5.49 & Service & 1.003 & 0.634 & 1.125 \\
\hline 75 & 25.00 & $12 \times 1$ & $24 \times 0.5$ & $14 \times 2$ & 18.75 & 6.64 & Strength & 0.998 & 0.773 & 1.125 \\
\hline 80 & 22.07 & $12 \times 1$ & $32 \times 0.5$ & $14 \times 1.5$ & 20 & 6.67 & Service & 0.985 & 0.707 & 1.200 \\
\hline 80 & 24.00 & $12 \times 1$ & $28 \times 0.5$ & $14 \times 2$ & 20 & 7.35 & Strength & 0.950 & 0.735 & 1.200 \\
\hline 85 & 19.81 & $12 \times 1$ & $40 \times 0.5$ & $12 \times 1.5$ & 21.25 & 7.23 & Service & 0.965 & 0.624 & 1.275 \\
\hline 85 & 23.18 & $12 \times 1$ & $32 \times 0.5$ & $14 \times 2$ & 21.25 & 8.10 & Constructibility & 0.985 & 0.709 & 1.275 \\
\hline 90 & 18.15 & $12 \times 0.75$ & $48 \times 0.5$ & $12 \times 1.5$ & 22.5 & 7.81 & Constructibility & 0.933 & 0.528 & 1.350 \\
\hline 90 & 24.69 & $14 \times 1$ & $32 \times 0.5$ & $16 \times 1.75$ & 22.5 & 8.88 & Strength & 1.003 & 0.850 & 1.350 \\
\hline 95 & 19.16 & $12 \times 1$ & $48 \times 0.5$ & $12 \times 1.5$ & 23.75 & 8.73 & Service & 0.950 & 0.623 & 1.425 \\
\hline 95 & 21.92 & $12 \times 1$ & $40 \times 0.5$ & $12 \times 2$ & 23.75 & 9.05 & Service & 0.950 & 0.740 & 1.425 \\
\hline 100 & 20.17 & $14 \times 0.75$ & $48 \times 0.5$ & $14 \times 1.5$ & 25 & 9.44 & Service & 0.939 & 0.671 & 1.500 \\
\hline 100 & 23.08 & $14 \times 1$ & $40 \times 0.5$ & $14 \times 2$ & 25 & 10.55 & Strength & 0.928 & 0.789 & 1.500 \\
\hline 105 & 21.09 & $14 \times 0.75$ & $48 \times 0.5$ & $14 \times 1.75$ & 26.25 & 10.54 & Constructibility & 0.937 & 0.713 & 1.575 \\
\hline 105 & 24.23 & $14 \times 1$ & $40 \times 0.5$ & $16 \times 2$ & 26.25 & 11.79 & Constructibility & 0.929 & 0.846 & 1.575 \\
\hline 110 & 22.09 & $14 \times 1$ & $48 \times 0.5$ & $14 \times 1.75$ & 27.5 & 11.70 & Service & 0.978 & 0.819 & 1.650 \\
\hline 110 & 25.38 & $14 \times 1.5$ & $40 \times 0.5$ & $16 \times 2$ & 27.5 & 13.66 & Strength & 0.996 & 0.968 & 1.650 \\
\hline 115 & 23.10 & $14 \times 1$ & $48 \times 0.5$ & $16 \times 1.75$ & 28.75 & 12.91 & Service & 0.957 & 0.870 & 1.725 \\
\hline 115 & 26.54 & $14 \times 1.5$ & $40 \times 0.5$ & $18 \times 2$ & 28.75 & 15.07 & Strength & 0.995 & 1.033 & 1.725 \\
\hline 120 & 24.00 & $16 \times 1$ & $48 \times 0.5$ & $16 \times 2$ & 30 & 14.70 & Strength & 0.936 & 0.909 & 1.800 \\
\hline 120 & 27.69 & $16 \times 1.5$ & $40 \times 0.5$ & $20 \times 2$ & 30 & 17.15 & Strength & 0.997 & 1.098 & 1.800 \\
\hline 125 & 25.00 & $16 \times 1.5$ & $48 \times 0.5$ & $16 \times 2$ & 31.25 & 17.01 & Strength & 0.998 & 1.018 & 1.875 \\
\hline 130 & 26.00 & $16 \times 1.5$ & $48 \times 0.5$ & $18 \times 2$ & 32.5 & 18.58 & Strength & 0.990 & 1.070 & 1.950 \\
\hline 135 & 27.00 & $16 \times 1.5$ & $48 \times 0.5$ & $20 \times 2$ & 33.75 & 20.21 & Strength & 0.986 & 1.151 & 2.025 \\
\hline 140 & 28.00 & $16 \times 1.5$ & $48 \times 0.5$ & $22 \times 2$ & 35 & 21.91 & Strength & 0.993 & 1.248 & 2.100 \\
\hline
\end{tabular}


Table A.31 Limited Exterior Plate Size Designs for 34-ft. Hybrid Cross Section in Accordance to the 3rd Edition of Specifications

\begin{tabular}{|c|c|c|c|c|c|c|c|c|c|c|}
\hline $\begin{array}{c}\text { Span } \\
\text { Length } \\
\text { (ft) }\end{array}$ & $L / D$ & $\begin{array}{l}\text { Top Flange } \\
\text { (in) }\end{array}$ & Web (in) & $\begin{array}{c}\text { Bottom Flange } \\
\text { (in) }\end{array}$ & $\begin{array}{l}\text { Lateral } \\
\text { Brace } \\
\text { Spacing }\end{array}$ & $\begin{array}{l}\text { Weight } \\
\text { (tons) }\end{array}$ & $\begin{array}{l}\text { Controlling Limit } \\
\text { State }\end{array}$ & $\begin{array}{c}\text { Performance } \\
\text { Ratio }\end{array}$ & $\begin{array}{l}\text { Deflection } \\
\quad \text { (in) }\end{array}$ & $\begin{array}{l}L / 800 \\
\text { (in) }\end{array}$ \\
\hline 40 & 13.81 & $12 \times 0.75$ & $24 \times 0.5$ & $12 \times 0.75$ & 10 & 2.04 & Strength & 0.536 & 0.196 & 0.600 \\
\hline 45 & 15.54 & $12 \times 0.75$ & $24 \times 0.5$ & $12 \times 0.75$ & 11.25 & 2.30 & Constructibility & 0.656 & 0.297 & 0.675 \\
\hline 50 & 17.27 & $12 \times 0.75$ & $24 \times 0.5$ & $12 \times 0.75$ & 12.5 & 2.55 & Constructibility & 0.781 & 0.425 & 0.750 \\
\hline 55 & 18.99 & $12 \times 0.75$ & $24 \times 0.5$ & $12 \times 0.75$ & 13.75 & 2.81 & Constructibility & 0.954 & 0.584 & 0.825 \\
\hline 60 & 20.72 & $12 \times 0.75$ & $24 \times 0.5$ & $14 \times 0.75$ & 15 & 3.22 & Strength & 0.973 & 0.714 & 0.900 \\
\hline 65 & 22.29 & $12 \times 0.75$ & $24 \times 0.5$ & $14 \times 1$ & 16.25 & 3.87 & Constructibility & 0.974 & 0.777 & 0.975 \\
\hline 70 & 19.65 & $12 \times 0.75$ & $32 \times 0.5$ & $12 \times 0.75$ & 17.5 & 4.05 & Strength & 1.002 & 0.759 & 1.050 \\
\hline 70 & 23.66 & $12 \times 1$ & $24 \times 0.5$ & $12 \times 1.5$ & 17.5 & 5.00 & Strength & 0.954 & 0.832 & 1.050 \\
\hline 75 & 20.93 & $12 \times 0.75$ & $32 \times 0.5$ & $12 \times 1$ & 18.75 & 4.72 & Strength & 0.973 & 0.810 & 1.125 \\
\hline 75 & 25.35 & $12 \times 1$ & $24 \times 0.5$ & $14 \times 1.5$ & 18.75 & 5.74 & Strength & 0.972 & 0.941 & 1.125 \\
\hline 80 & 22.33 & $12 \times 0.75$ & $32 \times 0.5$ & $14 \times 1$ & 20 & 5.31 & Strength & 0.998 & 0.910 & 1.200 \\
\hline 80 & 26.85 & $14 \times 1$ & $24 \times 0.5$ & $14 \times 1.75$ & 20 & 6.87 & Strength & 0.976 & 1.036 & 1.200 \\
\hline 85 & 20.00 & $12 \times 1$ & $40 \times 0.5$ & $12 \times 1$ & 21.25 & 6.36 & Strength & 0.948 & 0.786 & 1.275 \\
\hline 85 & 23.45 & $12 \times 1$ & $32 \times 0.5$ & $14 \times 1.5$ & 21.25 & 7.09 & Constructibility & 0.997 & 0.856 & 1.275 \\
\hline 90 & 21.18 & $12 \times 1$ & $40 \times 0.5$ & $14 \times 1$ & 22.5 & 7.04 & Strength & 0.960 & 0.866 & 1.350 \\
\hline 90 & 24.83 & $14 \times 1$ & $32 \times 0.5$ & $14 \times 1.5$ & 22.5 & 7.81 & Strength & 0.971 & 1.021 & 1.350 \\
\hline 95 & 19.32 & $12 \times 1$ & $48 \times 0.5$ & $12 \times 1$ & 23.75 & 7.76 & Strength & 0.910 & 0.774 & 1.425 \\
\hline 95 & 22.14 & $14 \times 0.75$ & $40 \times 0.5$ & $14 \times 1.5$ & 23.75 & 8.32 & Constructibility & 0.993 & 0.808 & 1.425 \\
\hline 100 & 20.34 & $12 \times 1$ & $48 \times 0.5$ & $12 \times 1$ & 25 & 8.17 & Strength & 0.988 & 0.907 & 1.500 \\
\hline 100 & 23.30 & $14 \times 1$ & $40 \times 0.5$ & $14 \times 1.5$ & 25 & 9.36 & Constructibility & 0.900 & 0.945 & 1.500 \\
\hline 105 & 21.36 & $12 \times 1$ & $48 \times 0.5$ & $14 \times 1$ & 26.25 & 8.93 & Strength & 0.991 & 0.976 & 1.575 \\
\hline 105 & 24.47 & $14 \times 1$ & $40 \times 0.5$ & $14 \times 1.5$ & 26.25 & 9.83 & Strength & 0.974 & 1.098 & 1.575 \\
\hline 110 & 22.18 & $14 \times 1$ & $48 \times 0.5$ & $14 \times 1.5$ & 27.5 & 11.04 & Strength & 0.851 & 0.897 & 1.650 \\
\hline 110 & 25.63 & $16 \times 1$ & $40 \times 0.5$ & $16 \times 1.5$ & 27.5 & 11.23 & Strength & 0.968 & 1.168 & 1.650 \\
\hline 115 & 23.19 & $14 \times 1$ & $48 \times 0.5$ & $14 \times 1.5$ & 28.75 & 11.54 & Strength & 0.915 & 1.029 & 1.725 \\
\hline 115 & 26.67 & $16 \times 1$ & $40 \times 0.5$ & $16 \times 1.75$ & 28.75 & 12.52 & Constructibility & 0.964 & 1.215 & 1.725 \\
\hline 120 & 24.20 & $16 \times 1$ & $48 \times 0.5$ & $16 \times 1.5$ & 30 & 13.07 & Constructibility & 0.931 & 1.083 & 1.800 \\
\hline 120 & 27.83 & $14 \times 1.5$ & $40 \times 0.5$ & $16 \times 1.75$ & 30 & 14.09 & Strength & 1.003 & 1.378 & 1.800 \\
\hline 125 & 25.21 & $16 \times 1.5$ & $48 \times 0.5$ & $16 \times 1.5$ & 31.25 & 15.31 & Strength & 0.965 & 1.216 & 1.875 \\
\hline 130 & 26.11 & $16 \times 1.5$ & $48 \times 0.5$ & $16 \times 1.75$ & 32.5 & 16.81 & Strength & 0.934 & 1.247 & 1.950 \\
\hline 135 & 27.11 & $16 \times 1.5$ & $48 \times 0.5$ & $16 \times 1.75$ & 33.75 & 17.46 & Strength & 0.991 & 1.429 & 2.025 \\
\hline 140 & 28.00 & $16 \times 1.75$ & $48 \times 0.5$ & $16 \times 2$ & 35 & 20.01 & Strength & 0.984 & 1.499 & 2.100 \\
\hline
\end{tabular}

